\title{
Rafael Luís Galdini Raimundo
}

\section{A seleção natural e a estrutura, dinâmica e diversificação de assembleias de espécies mutualistas}

\section{São Paulo}

2015

\section{Versão Corrigida}

A versão original desta tese está disponível na Biblioteca do Instituto de Biociências da Universidade de São Paulo. 


\title{
RAFAEL LUÍS GALDINI RAIMUNDO
}

\section{A seleção natural e a estrutura, dinâmica e diversificação de assembleias de espécies mutualistas}

Tese apresentada ao Instituto de Biociências da Universidade de São Paulo para obtenção do título de Doutor em Ciências

\author{
Área de Concentração: \\ Ecologia de Ecossistemas \\ Terrestres e Aquáticos
}

Orientador: Prof. Dr. Paulo R. Guimarães Jr. 


\section{Ficha Catalográfica}

Raimundo, Rafael Luís Galdini.

A seleção natural e a estrutura, dinâmica e diversificação de assembleias de espécies mutualistas / Rafael Luís Galdini Raimundo ; orientador Paulo Roberto Guimarães Junior. -- São Paulo, 2015. $186 \mathrm{f}$.

Tese (Doutorado) - Instituto de Biociências da Universidade de São Paulo. Departamento de Ecologia.

1. Interações Ecológicas. 2. Especiação. 3. Redes Ecológicas. 4. Estabilidade. I. Guimarães Junior, Paulo Roberto. II. Universidade de São Paulo. Instituto de Biociências. Departamento de Ecologia. III. Título. 


\section{FOLHA DE APROVAÇÃo}

RAIMUNDO, R. L. G. A seleção natural e a estrutura, dinâmica e diversificação de assembleias de espécies mutualistas. Tese apresentada ao Instituto de Biociências da Universidade de São Paulo para obtenção do título de Doutor em Ciências.

Aprovado em:

Banca examinadora

Prof. Dr.:

Instituição:

Julgamento: Assinatura:

Prof. Dr.: Instituição:

Julgamento: Assinatura:

Prof. Dr.: Instituição:

Julgamento: Assinatura:

Prof. Dr.: Instituição:

Julgamento: Assinatura:

Prof. Dr.: Instituição:

Julgamento: Assinatura: 
Para Camila, Pedro e Miguel. 


\section{AgRADECIMENTOS}

Ao meu orientador, Paulo R. Guimarães Jr, pelas oportunidades de aprendizagem e crescimento profissional ao longo dos últimos anos.

À Fundação de Amparo à Pesquisa do Estado de São Paulo (FAPESP) pelo apoio financeiro que viabilizou a realização desta Tese (Bolsa de Doutorado, processo FAPESP \#2011/13054-6). Também à Coordenação de Aperfeiçoamento de Pessoal de Nível Superior (CAPES), pela concessão de bolsa de Doutorado (Demanda Social) por um período de seis meses, no início do meu curso.

A minha esposa, Camila e aos meus filhos, Pedro e Miguel, por todo o apoio ao longo dos anos de caminhada conjunta e por, com sua alegria e companheirismo, constantemente me mostrarem o que realmente é importante.

Aos meus pais, Eduardo e Terezinha, e aos meus irmãos, por sempre terem apoiado totalmente minhas decisões e que permitiram que eu me tornasse aquilo que escolhi ser.

Aos meus colegas de laboratório e aos meus colaboradores, pelas conversas estimulantes e experiências compartilhadas ao longo de anos.

Aos professores e funcionários da Universidade de São Paulo, de forma geral, e aos do Instituto de Biociências e do Programa de Pós-Graduação em Ecologia da USP, em particular, por propiciarem um ambiente acadêmico de excelência. 
"... The most important kind of freedom is to be what you really are." Jim Morrison 


\section{RESUMO}

RAIMUNDO, R. L. G. A seleção natural e a estrutura, dinâmica e diversificação de assembleias de espécies mutualistas. 2015. 186 f. Tese de Doutorado. Instituto de Biociências, Universidade de São Paulo, São Paulo.

A adaptação e a diversificação em sistemas multiespecíficos são crescentemente reconhecidas como processos relevantes para a compreensão da biodiversidade. Nosso objetivo foi investigar como a seleção natural relacionada a interações ecológicas influencia a estrutura, dinâmica e diversificação de assembleias mutualistas. Primeiro, modelamos como mutualismo e competição intraespecífica geram regimes seletivos antagônicos que definem padrões de diversificação. Nossos modelos preveem que em mutualismos de baixa intimidade, nos quais cada organismo têm muitos parceiros individuais, fenótipos extremos têm interações mutualísticas desajustadas em relação à complementaridade de traços, contrabalanceando efeitos diversificadores da competição intraespecífica e restringindo a especiação. Em sistemas de alta intimidade, nos quais mutualismos têm maior impacto adaptativo e cada organismo têm poucos parceiros, tal seleção estabilizadora imposta por mutualismos é reduzida, favorecendo a diversificação. Entretanto, mutualismos de baixa intimidade são mais ricos que mutualismos íntimos na natureza. Sob baixa intimidade de interações, adições de espécies não-aparentadas envolvidas em dinâmicas de convergência constituem explicação plausível para essa discrepância. Em sistemas de alta intimidade, restrições a adições de espécies impostas por histórias coevolutivas estreitamente relacionadas poderiam explicar menores riquezas, apesar do maior potencial de diversificação adaptativa. Em segundo lugar, avaliamos se reconfigurações adaptativas das interações ecológicas podem explicar a variação estrutural de redes mutualistas. Usando um modelo eco-evolutivo, mostramos que a seleção favorecendo trocas de mutualistas e maximizando a abundância das espécies altera propriedades das redes, aumentando seu aninhamento e diminuindo sua estabilidade. Nossos modelos superestimaram o aninhamento em mutualismos de alta intimidade, possivelmente porque não consideramos ligações proibidas impostas por morfologia ou fenologia. Entretanto, as redes simuladas reproduzem aninhamento e modularidade de mutualismos de baixa intimidade, cujas interações são mais flexíveis. Sob competição por mutualistas, as reconfigurações da rede continuam em um dinâmica sem fim, mesmo quando estrutura e a estabilidade atingem níveis assintóticos, o que pode explicar a 
variação empírica de interações em redes com estruturas temporalmente constantes. Em um terceiro estudo, modelamos como diferentes modos de especiação modificam propriedades de redes mutualistas. Se a especiação resulta em expansão do nicho e as espécies emergentes tornarem-se mais conectadas, o aninhamento aumenta e a modularidade diminui, frequentemente resultando em redes instáveis. Se a especiação causar retração do nicho e as espécies emergentes tornarem-se menos conectadas, aninhamento e modularidade aumentam, promovendo estabilidade. Diferentes regras de sobreposição de nicho entre espécies emergentes não alteraram esses resultados. Assim, retrações de nicho via divergência adaptativa, como deslocamentos de caracteres na especiação simpátrica, devem gerar espécies incorporáveis às redes mutualistas sem desestabilização. Entretanto, expansões de nicho via adaptações a recursos complementares em alopatria devem desestabilizar as redes quando do contato secundário. Efeitos potencialmente amplos de um único evento de especiação mostram que estudos relacionando diversificação e dinâmica são relevantes para o debate sobre complexidade e estabilidade de redes ecológicas. Concluímos que a compreensão mecanística sobre as origens e a manutenção da biodiversidade depende da integração de teorias ecológicas e evolutivas com base em dados empíricos, como fizemos aqui ao modelar dinâmicas adaptativas de interações ecológicas usando informações sobre a organização e história natural de assembleias mutualistas.

Palavras-chave: Diversificação adaptativa. Dinâmicas eco-evolutivas. Especiação. Estabilidade comunitária. Evolução rápida. Interações ecológicas. Intimidade de Interação. Redes Ecológicas. 


\begin{abstract}
RAIMUNDO, R. L. G. Natural selection and the structure, dynamics, and diversification of mutualistic assemblages. 2015. 186 p. Tese (Doutorado). Instituto de Biociências, Universidade de São Paulo, São Paulo.
\end{abstract}

Adaptation and diversification in species-rich systems are increasingly recognized as relevant processes to improve our understanding on biodiversity. Our aim was to investigate how natural selection related to ecological interactions shapes the structure, dynamics and diversification of mutualistic assemblages. First, we modeled how mutualism and intraspecific competition generate antagonistic selective regimes that define patterns of diversification. Ours models predict that in low intimacy mutualisms, in which each organism has various individual partners, extreme phenotypes experience trait mismatches in mutualistic interactions that oppose the diversifying effects of intraspecific competition and constrain speciation. In high intimacy systems, in which mutualistic interactions have a higher impact on fitness and each organism has fewer partners, such stabilizing selection is reduced, favoring diversification. However, low intimacy mutualisms are richer than high intimacy mutualisms in nature. Under low interaction intimacy, additions of non-related species involved in trait convergence dynamics are a plausible explanation for such a discrepancy. In high intimacy systems, restrictions to species additions imposed by tight coevolutionary histories could explain lower richnesses despite of a higher potential for adaptive diversification. In a subsequent study, we evaluated whether the adaptive rewiring of ecological interactions explain the structural variation of mutualistic networks. Using an ecoevolutionary model, we show that selection favoring continuous interaction switching that maximizes species abundances changes network properties, increasing nestedness and decreasing stability. Our models overestimated nestedness in high intimacy mutualisms, probably because we did not consider forbidden links imposed by morphology or phenology. However, simulated networks reproduce nestedness and modularity of low intimacy mutualism, in which interactions are more flexible. Under competition for mutualists, rewires continue in an endless dynamics, even when the structure and stability reach asymptotic levels at the network level, which could explain the empirical variation of interactions in networks showing temporally constant structures. In a third study, we modeled effects of different modes of speciation on mutualistic network properties. If speciation results in niche width 
expansion and emerging species become more connected, nestedness increases and modularity decreases, often resulting in unstable networks. If speciation causes niche width retractions and emerging species become less connected, both nestedness and modularity increase, promoting stability. Different rules of niche overlap between emerging rules did not change these results. Therefore, niche retractions via adaptive divergence, such as character displacement in sympatric speciation, can generate species that will enter local networks without destabilizing them. However, niche width expansions due to adaptation to additional resources in allopatry should destabilize networks if secondary contact between emerging species occur. High magnitude potential effects of a single speciation event show that studies relating diversification and dynamics are relevant to the debate on complexity and stability of ecological networks. We concluded that the mechanistic understanding of biodiversity origins and maintenance relies on the integration between ecological and evolutionary theories based on empirical data, as wed did here by modeling the adaptive dynamics of ecological interactions using information on the structure and natural history of mutualistic assemblages.

Keywords: Adaptive diversification. Community stability. Ecological interactions. Ecological networks. Eco-evolutionary dynamics. Interaction Intimacy. Rapid evolution. Speciation. 


\section{SUMÁRIO}

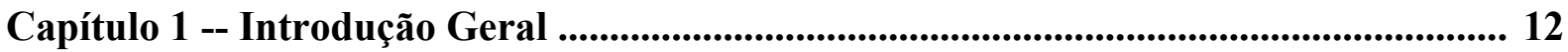

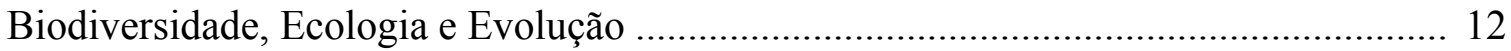

A seleção natural imposta por interações bióticas e a especiação .................................. 13

Seleção natural, variação estrutural e a dinâmica de redes ecológicas ............................ 14

Especiação, reorganização do nicho e estabilidade ........................................................ 17

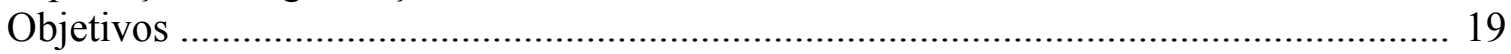

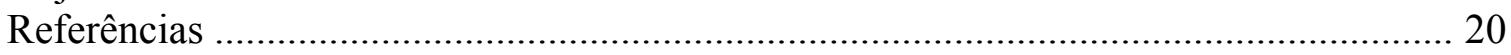

Capítulo 2 -- Conflicting selection in the course of adaptive diversification: the interplay between mutualism and intraspecific competition ............................................................ 26

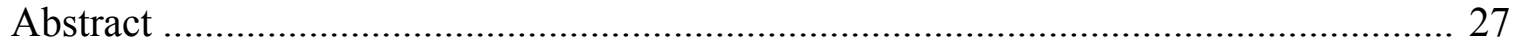

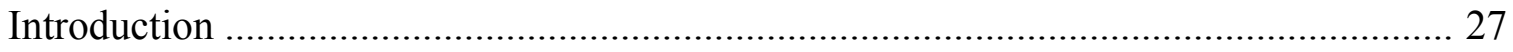

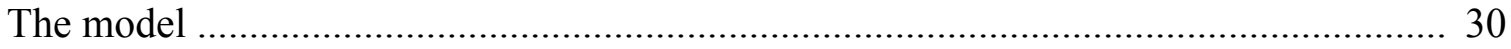

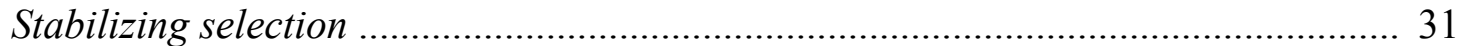

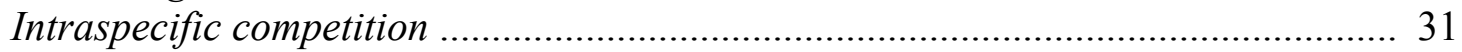

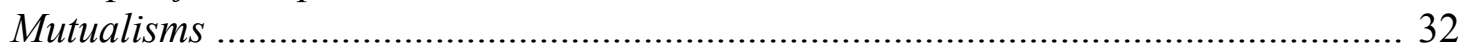

Mate choice, reproduction, and death ............................................................ 33

Number of different mutualistic partners and impact of trait matching on fitness .......... 34

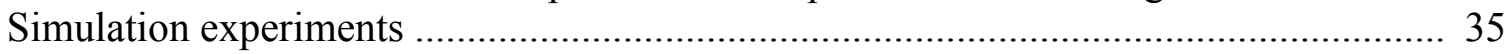

Experiment 1: Intimate mutualisms, mating pool composition, and diversification ... 35

Experiment 2: The effect of different types of mutualism on diversification ............... 36

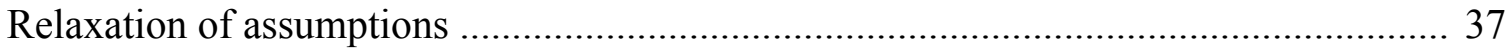

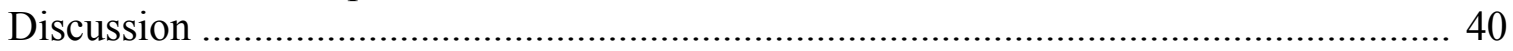

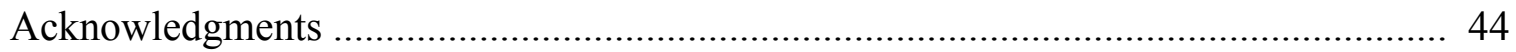

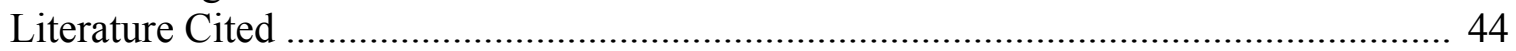

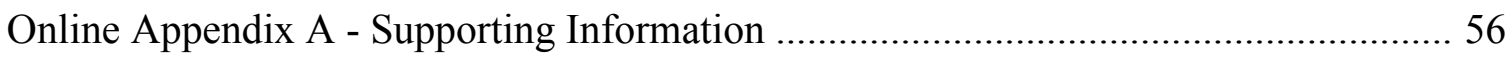

Capítulo 3 -- Does adaptive rewiring explain the structural diversity of mutualistic

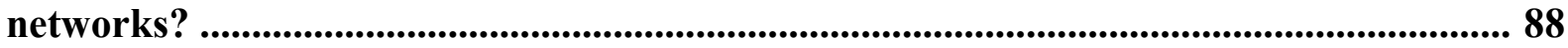

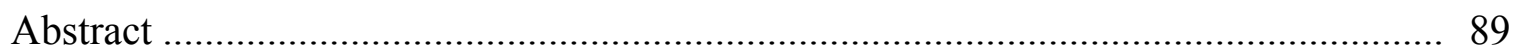

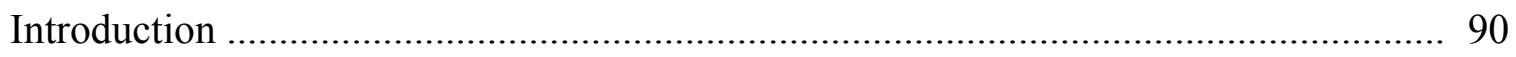

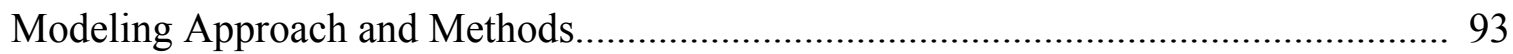

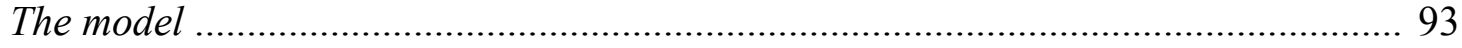

Adaptive rewiring algorithm ............................................................................ 95

Numerical simulations using empirical data from high and low intimacy mutualisms 96

Assessing effects of adaptive rewiring on mutualistic networks ............................... 97

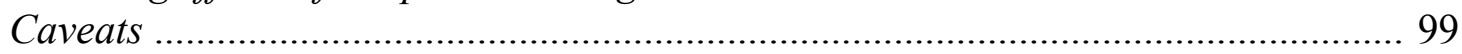

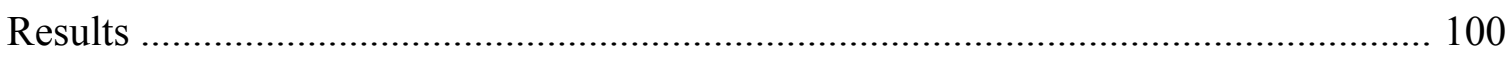

General effects of adaptive rewiring on model mutualistic networks ..................... 100

Structural fit between model and empirical networks ............................................. 101

Interspecific competition regimes and dynamics of mutualistic assemblages .......... 102

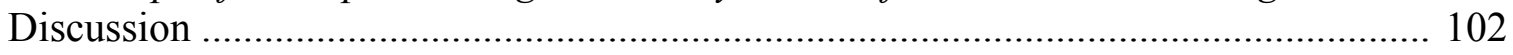

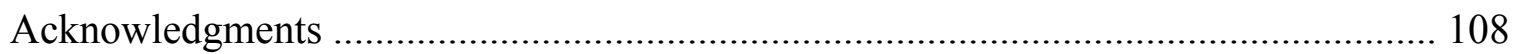

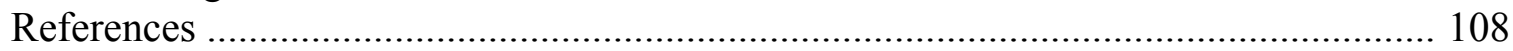

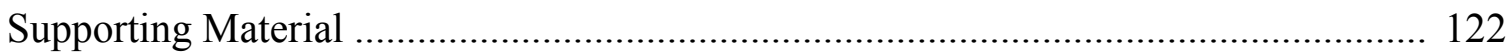




\section{SUMÁRIO (CONTINUAÇÃo)}

Capítulo 4 -- Speciation, niche reorganization and the stability of mutualistic

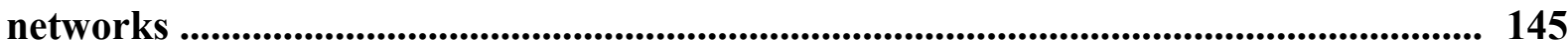

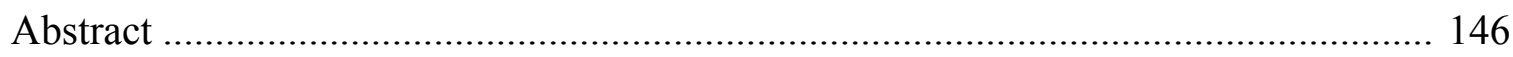

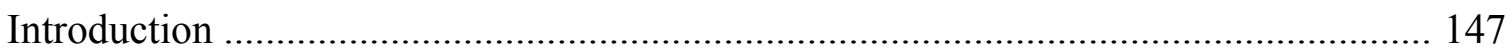

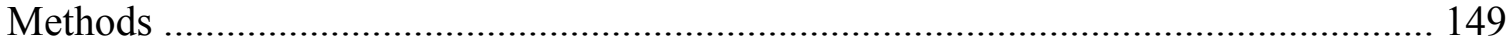

Simulating speciation modes and their effects on biotic niche organization ............ 149

Dataset and types of mutualistic networks ........................................................... 151

Assessing the effects of speciation on network structure ....................................... 152

Assessing the effects of speciation on community stability .................................... 153

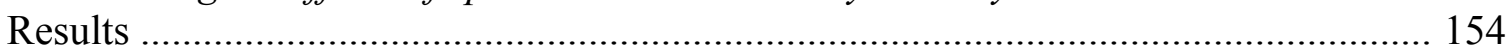

Effects of speciation mode on network structure ................................................. 154

Effects of speciation mode on stability ................................................................... 156

Relationships between structural changes and community dynamics .................... 157

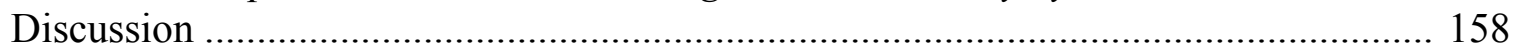

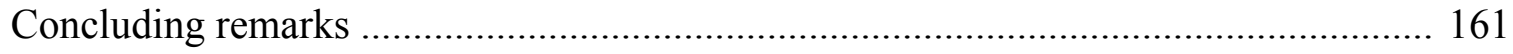

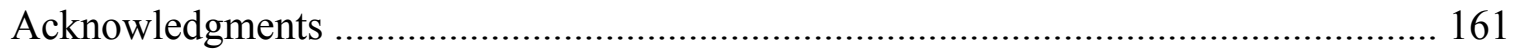

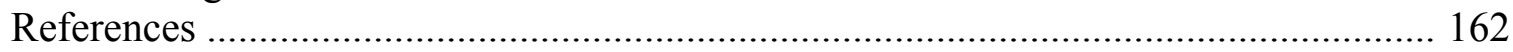

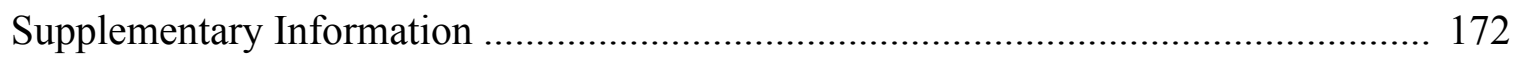

References cited in the Supporting Information ............................................... 174

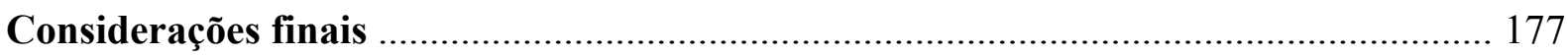

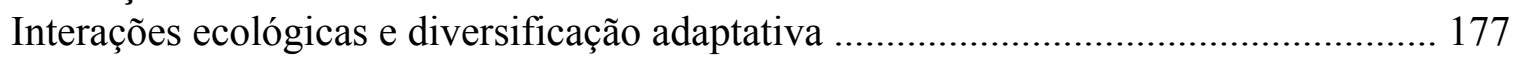

Reconfigurações adaptativas e variação estrutural de redes mutualistas ....................... 178

Efeitos da especiação sobre a estrutura e estabilidade de redes mutualistas ................ 179

Linhas de investigação possíveis para o futuro ........................................................... 180

Diversificação adaptativa e seleção conflitante .................................................... 180

Redes adaptativas: processos anagenéticos e especiação ........................................ 181

A natureza da biodiversidade e o desafio central para a modelagem eco-evolutiva ..... 183

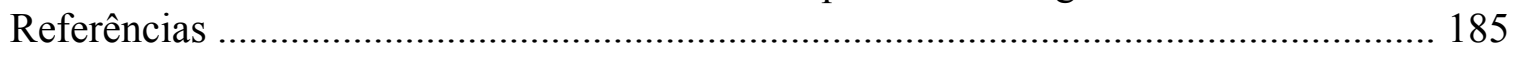




\section{CAPÍtulo 1}

\section{Introdução Geral}

\section{Biodiversidade, ecologia e evolução}

A aplicação de conceitos evolutivos é uma estratégia central para a Biologia frente ao desafio de aprofundar-se a compreensão dos processos que geram e mantêm a diversidade biológica (Losos et al. 2013). A estrutura da biodiversidade transpassa os diferentes níveis de organização biológica, mas tem como elemento fundamental as populações que constituem tanto unidades genealógicas, das quais emergem novas espécies, como unidades ecológicas que constituem as comunidades (Eldredge 1985). A dinâmica da biodiversidade, portanto, pode ser compreendida como o conjunto de processos ecológicos e evolutivos atuando sobre as populações e que moldam, ao longo do tempo, as propriedades comunitárias, tais como riqueza, padrões de interações ecológicas e estabilidade (McKinney \& Drake 1998; Thompson 2005). Ao longo das últimas décadas, diferentes linhas de investigação têm buscado entender a biodiversidade em seus aspectos estruturais (Dunne 2006; Bascompte \& Jordano 2007) e dinâmicos (May 1973; McCann 2000; Herrera \& Pellmyr 2002; Allesina \& Tang 2012). Além disso, uma nova síntese da teoria de especiação tem reafirmado o papel central de processos ecológicos em processos de diversificação, os quais são mais recorrentes do que anteriormente supunha-se (Schluter 2000; Dieckmann et al. 2004; Gavrilets 2004; Thompson 2005; Nosil 2012). Nesse contexto, são cada vez mais necessárias abordagens integradoras que investiguem os papéis dos diferentes processos ecológicos e evolutivos que mediam as relações entre diversidade, estrutura e dinâmica em diferentes tipos de comunidades (Loreau 2010; Rooney \& McCann 2012).

A integração de conhecimentos sobre a estrutura, dinâmica e diversificação de comunidades ecológicas cada vez mais requer o aprofundamento de uma perspectiva ecoevolutiva (Odling-Smee et al. 2003; Pelletier et al. 2009). A abordagem eco-evolutiva fundamenta-se na percepção de que processos microevolutivos têm efeitos estruturais e dinâmicos amplos sobre a ecologia das comunidades (Thompson 1998). Estudos empíricos e modelos eco-evolutivos, portanto, abordam a intersecção entre o foco tradicional da Evolução, que investiga a variação das frequências gênicas e fenotípicas e suas relações com a adaptação e a diversificação, e o da Ecologia, que estuda os padrões de distribuição, abundância e interações das espécies. Sem negar o papel de processos operando ao longo do 
tempo geológico, o paradigma eco-evolutivo enfatiza que interações entre espécies podem evoluir rapidamente, alterando padrões de diversidade genética e de interações ecológicas em períodos tão curtos quanto décadas e relativizando assim a dicotomia usual entre tempo ecológico e tempo evolutivo (Thompson 1998; 1999). Entretanto, dinâmicas eco-evolutivas não dependem necessariamente de evolução rápida e mudanças ecológicas lentas -- a condição suficiente é uma congruência das escalas de tempo que permita retroalimentações entre ecologia e evolução (Lewontin 2000; Post \& Palkovacs 2009; Nonaka 2014).

\section{A seleção natural imposta por interações bióticas e a especiação}

Dentre as relações entre ecologia e microevolução que governam a organização e a dinâmica da biodiversidade, um aspecto central é o papel da seleção natural ${ }^{1}$ advinda de interações ecológicas ou atuando sobre elas (Schluter 1996; Kingsolver et al. 2001; Thompson 2009). Os seres vivos interagem com indivíduos de outras espécies e com coespecíficos de forma competitiva, antagonista ou cooperativa, o que influencia seu crescimento, sobrevivência e/ou fecundidade e contribui, juntamente com fatores abióticos, na definição de sua aptidão ${ }^{2}$ (Herrera 2000; Schaeffer et al. 2013). Diferentes tipos de interações ecológicas resultam em pressões seletivas potencialmente conflitantes que influenciam a evolução e diversificação de traços fenotípicos (Strauss \& Irwin 2004; Siepielski \& Benkman 2009).

No nível de população, as interações ecológicas podem frequentemente impor regimes seletivos diversificantes (Kingsolver et al. 2001), tal como a seleção disruptiva causada por competição intraespecífica (Maynard Smith 1962; Rosenzweig 1978; Dieckmann \& Doebeli 1999) ou resultante de outras interações dependentes de frequência (Doebeli \& Dieckmann 2000). Os regimes disruptivos impostos por interações ecológicas, se associados a acasalamentos preferenciais positivos ("assortative mating"), podem gerar biodiversidade, desde o nível de polimorfismos até eventos de especiação e irradiações adaptativas (Dieckmann et al. 2004; Ito \& Dieckmann 2007). Por outro lado, é esperado que o conflito entre forças seletivas advindas de diferentes tipos de interações ecológicas eventualmente restrinja a diversificação. Por exemplo, a especiação competitiva (Rosenzweig 1978) pode ser limitada por seleção estabilizadora imposta por mutualismos caracterizados por complementaridade de traços ("trait matching"), nos quais os fenótipos intermediários

\footnotetext{
${ }^{1}$ A seleção natural é a diferença, em média, da sobrevivência e fecundidade de indivíduos detentores de um traço fenotípico herdável em relação a indivíduos com outros traços (Pfennig \& Kingsolver 2009).

${ }^{2}$ Define-se aptidão como a contribuição para o estoque genético da próxima geração feita por um indivíduo em relação aos outros indivíduos na mesma população (Pfennig \& Kingsolver 2009).
} 
comuns teriam melhores ajustes fenotípicos em relação aos parceiros mutualistas disponíveis (Thompson 2005), contrabalanceando assim os benefícios adaptativos conferidos pela reduzida competição intraespecífica aos fenótipos extremos raros. A investigação do papel da seleção conflitante como limitadora da diversificação quando os traços fenotípicos sob seleção disruptiva também mediam outras interações ecológicas pode inserir os modelos de especiação adaptativa em um contexto comunitário mais amplo e também permitir uma caracterização mais aprofundada dos efeitos de diferentes tipos de mutualismos sobre a dinâmica evolutiva (Paracer \& Ahmadjian 2000; Guimarães et al. 2007a; Bronstein 2009).

\section{Seleção natural, variação estrutural e a dinâmica de redes ecológicas}

Além de ajudar na compreensão dos padrões de diversificação de espécies, a investigação de processos adaptativos relacionados às interações mutualísticas pode ajudar no entendimento mecanístico dos padrões estruturais e da dinâmica de comunidades ecológicas (Guimarães et al. 2011; Suweis et al. 2013; Bascompte \& Jordano 2014). Na natureza, mutualismos geralmente abrangem múltiplas espécies interagentes cujas ligações podem ser descritas por grafos (Harary 1994). De fato, interações ecológicas frequentemente são representadas como grafos bipartidos nos quais as espécies de um conjunto (por exemplo, polinizadores) são indicadas por nós e suas interações com as espécies do outro conjunto (por exemplo, plantas) são descritas por conexões (Bascompte \& Jordano 2008). Os padrões estruturais de redes mutualistas foram extensivamente registrados ao longo da última década, revelando formas de organização das interações recorrentes em diferentes sistemas biológicos, tais como o aninhamento $^{3}$ (Bascompte et al. 2003) e a modularidade ${ }^{4}$ (Olesen et al. 2007).

Parte dos mecanismos propostos para explicar a variação estrutural de redes mutualísticas referem-se a processos neutros. Tal abordagem presume que as interações observadas resultariam de probabilidades de interação entre indivíduos interespecíficos proporcionais às abundâncias relativas das espécies, considerando-as, portanto, como ecologicamente equivalentes (Krishna et al. 2008). Por outro lado, processos que impõem limitações às interações que podem ocorrer, tais como ligações proibidas ("forbidden links")

\footnotetext{
${ }^{3} \mathrm{O}$ aninhamento é um padrão estrutural no qual, em um grafo bipartido, as espécies de um conjunto (e.g., plantas) com menor grau (número de interações) interagem com subconjuntos de espécies do outro conjunto (e.g., polinizadores) ligadas às espécies com maior grau (Bascompte et al. 2003). Portanto, em uma rede aninhada as espécies de grau alto frequentemente interagem entre si e também com espécies de grau baixo, enquanto as espécies grau baixo interagem entre si mais raramente (Guimarães 2009).

${ }^{4}$ A modularidade é um padrão estrutural no qual ocorrem subconjuntos de espécies com muitas conexões internas e poucas conexões com outros subconjuntos de espécies na rede (Bascompte \& Jordano 2014).
} 
definidas por diferenças morfológicas, fenológicas ou distribucionais que tornam impossíveis a ocorrência de determinadas interações que, portanto, constituem "zeros estruturais" nas matrizes que descrevem as redes bipartidas (Jordano et al. 2003; Olesen et al. 2011). A avaliação comparativa das contribuições relativas de processos neutros e ligações proibidas para a estrutura de redes mutualistas indica que esses processos, isoladamente ou em conjunto, não são suficientes para explicar a variação estrutural das redes mutualistas (Vázquez et al. 2009), o que indica a necessidade de considerarem-se outros processos que possam explicar padrões arquiteturais observados na natureza.

Explicações alternativas para a estrutura de redes ecológicas podem ser obtidas a partir da plataforma conceitual de redes adaptativas, definidas como sistemas nos quais a evolução estrutural da rede e as propriedades dos nós influenciam-se reciprocamente (Gross \& Blasius 2008). A teoria de redes adaptativas aborda de forma integrada as inter-relações entre a dinâmica das redes e as dinâmicas que ocorrem dentro das redes, explorando assim as retroalimentações que, ao longo do tempo, emergem entre a topologia e o estado coletivo dos nós (Gross \& Sayama 2009). Por exemplo, mudanças nos padrões de interações mutualistas que aumentem a aptidão dos indivíduos constituem uma modificação estrutural da rede ecológica e também influenciam a dinâmica populacional das espécies que a constituem. Rearranjos de interações mutualistas constituem reconfigurações adaptativas ("adaptive rewiring", González-Avella et al. 2014), pois modificam simultaneamente a estrutura da rede e as abundâncias das espécies e assim podem gerar retroalimentações entre a organização das interações ecológicas e as dinâmicas populacionais.

Trabalhos teóricos recentes propuseram que reconfigurações adaptativas podem ser um mecanismo geral estruturando redes mutualistas. Modelos mostraram que, em redes cujas interações são estabelecidas inicialmente de forma aleatória, a seleção natural favorecendo novas interações mutualistas que otimizem a abundância das espécies resulta em aumento do aninhamento ao longo do tempo (Zhang et al. 2011; Suweis et al. 2013). Esse mecanismo baseia-se na teoria que conecta Biologia de populações ao conceito de aptidão: os traços fenotípicos (interações) aumentam em frequência se as taxas de crescimento intrínsecas a eles associadas forem maior do que a média da população (Fisher 1930), levando assim a um incremento da abundância. Adicionalmente, o trabalho de Suweis et al. (2013) previu que uma consequência do aumento do aninhamento nesses modelos de evolução de redes mutualistas seria a diminuição de sua estabilidade (i.e., da tendência do sistema de retornar ao equilíbrio após uma pequena perturbação), conforme inferido a partir de análise de estabilidade local em sistemas de equações diferenciais (May 1973; Allesina \& Tang 2012; 
Brassil 2012). Essa previsão contrapõe-se a modelos matemáticos que sugerem que consequências do aninhamento, tal como a minimização da competição interespecífica via facilitação (Bastolla et al. 2009), resultariam em estabilidade.

Mais estudos são necessários para investigar as previsões sobre a estabilidade em modelos de reconfigurações adaptativas e para verificar a generalidade desse mecanismo como explicação para a variação estrutural de mutualismos (Guimarães et al. 2007a). Estudos sobre o tema exploraram redes teóricas de dimensões e conectâncias arbitrárias (Suweis et al. 2013) ou usaram propriedades empiricamente informadas, mas de uma gama restrita de sistemas mutualistas, tais como os de polinização ou dispersão de sementes (Zhang et al. 2011; Ramos-Jiliberto et al. 2012). A avaliação da generalidade do mecanismo de reconfigurações adaptativas requer uma tipologia dos sistemas mutualistas que tenha, em algum nível, abrangência biológica. Uma possibilidade para a constituição de tal tipologia é a categorização de redes mutualistas em relação à intimidade das interações, aqui definido como o grau de integração morfológica, fisiológica e/ou comportamental entre as espécies interagentes (Ollerton 2006).

Mutualismos de baixa intimidade são caracterizados por um impacto relativamente pequeno de cada evento de interação sobre a aptidão, além de um grande número de parceiros mutualistas individuais por organismo mutualista. Por outro lado, em mutualismos de alta intimidade, cada interação tem um efeito alto sobre a aptidão e os indivíduos estão biologicamente integrados a um ou poucos parceiros mutualistas individuais (Ollerton 2006). Apesar dos atributos usados para definir intimidade de interação (impacto dos eventos de interação sobre a aptidão e número de parceiros mutualistas individuais) estarem frequentemente correlacionados, exceções podem ser indicadas. Por exemplo, um grande número de simbiontes vivendo intimamente associados a um único hospedeiro mutualista (Douglas 1994; Bronstein 2009) contraria a noção de que em mutualismos íntimos os organismos têm poucos parceiros individuais. A intimidade de interação influencia a estrutura e a dinâmica evolutiva de redes ecológicas (Guimarães et al. 2007a, Pires \& Guimarães 2013) e, portanto, também espera-se que influencie aspectos da estabilidade das comunidades como, por exemplo, a suscetibilidade de espécies à extinção (Dáttilo 2012).

Mutualismos de baixa intimidade incluem interações entre plantas e animais dispersores de sementes (Herrera 1995), entre formigas e plantas com nectários extraflorais (Díaz-Castelazo et al. 2013), entre peixes ou crustáceos limpadores e peixes clientes (Guimarães et al. 2007b) e entre plantas e animais polinizadores (Waser \& Ollerton 2006; Patiny 2012). Redes de baixa intimidade são frequentemente aninhadas e uma maior 
suscetibilidade prevista em relação à propagação de efeitos ecológicos e evolutivos (Guimarães et al. 2007a; 2011). Já em mutualismos de alta intimidade, as interações ecológicas são resultados de histórias coevolutivas estreitamente relacionadas entre as espécies envolvidas, como ilustrado por interações obrigatórias entre: formigas e plantas mirmecófitas (Fonseca \& Ganade 1996), peixes gobídeos e camarões (Thompson et al. 2013), plantas do gênero Glochidion e seus polinizadores parasitas de sementes (Hembry 2012) e peixes palhaço e anêmonas hospedeiras (Ricciardi et al. 2010). Redes ecológicas de alta intimidade têm aninhamentos menores que redes de baixa intimidade (Guimarães et al. 2007, Thébault \& Fontaine 2010; Pires \& Guimarães 2013) e, por outro lado, têm graus de modularidade maiores (Guimarães et al. 2007a; Gómez et al. 2010). Ainda, mutualismos íntimos resultam de processos coevolutivos estreitamente relacionados que favorecem especialização recíproca (Thompson 2005). Uma consequência dinâmica da modularidade e da especialização recíproca em mutualismos de alta intimidade seria a menor suscetibilidade à perturbações no nível de rede (Olesen et al. 2007), mesmo considerando-se a previsão de riscos maiores de extinções de espécies ou de interações (coextinções) (Dáttilo 2012).

\section{Especiação, reorganização do nicho e estabilidade}

O mecanismo de reconfiguração adaptativa descrito acima é um processo anagenético, ou seja, a seleção natural modifica os padrões de interação ecológica e otimiza a abundância de populações sem que, entretanto, surjam novas espécies. A especiação é outro mecanismo de reconfiguração das interações ecológicas, a qual decorre da reorganização das dimensões bióticas do nicho ao longo do processo de divergência ou quando do contato secundário, nos casos de alopatria. Mudanças estruturais são esperadas em redes ecológicas a partir de eventos de especiação porque processos de diversificação de espécies modificam de forma simultânea múltiplos atributos do ambiente biótico (Schluter 2000; Nosil 2012). De fato, a reorganização das interações ecológicas nas espécies emergentes frequentemente modificará a amplitude e sobreposição de suas dimensões bióticas do nicho (Anacker \& Strauss 2014), uma vez que a divergência adaptativa em traços mediadores de interações ecológicas possibilita a coexistência das espécies irmãs (Schluter 2000).

A evolução dos padrões de interações ecológicas baseia-se em variações de nicho ecológico geneticamente definidas, tanto entre como dentro de populações (Svanbäck \& Bolnick 2007). Assim como quaisquer características biológicas, os traços que mediam interações ecológicas, tais como morfologia, fenologia, e preferências alimentares ou de 
habitat, exibem variabilidade intrapopulacional e geográfica (Bolnick et al. 2003; Mezquida \& Benkman 2014; Poisot et al. no prelo). Portanto, a diversificação desses traços pode ocorrer sob condições geográficas variadas, incluindo uma gama de configurações espaciais que abrangem desde a simpatria (Doebeli \& Dieckmann 2000) até a alopatria (Losos \& Mahler 2010). Em relação aos processos diversificadores, a especiação mediada por interações ecológicas pode estar relacionada à seleção natural, seleção sexual e/ou deriva genética sob diferentes estruturas espaciais (Dieckmann et al. 2004; Price 2008).

Os efeitos da especiação sobre a estrutura das redes de interações devem variar conforme os processos ecológicos e microevolutivos que moldam a cladogênese. Assim, espera-se que diferentes modos de especiação tenham efeitos variados sobre a amplitude e sobreposição de nicho das espécies emergentes. Por exemplo, a especiação pode resultar em redução da amplitude de nicho, com cada uma das espécies emergentes especializando-se em subconjuntos diferentes dos recursos existentes. A redução da amplitude de nicho é plausível sob diferentes processos de diversificação adaptativa, tais como: a especiação competitiva simpátrica (Doebeli \& Dieckmann 2000; Bhattacharyay \& Drossel 2005), a especiação ecológica conduzida por adaptações locais distintas decorrente de seleção divergente entre habitats (Nosil 2012) ou a coevolução diversificante caracterizada por especialização recíproca (Thompson 2005). Por outro lado, a especiação pode resultar em aumento da amplitude de nicho em ambas as espécies emergentes quando, por exemplo, a divergência ocorre em alopatria e é seguida por contato secundário. Por serem ecologicamente similares, as espécies emergentes em contato secundário podem adaptar-se localmente a recursos alternativos distintos, o que resultaria em minimização da competição interespecífica porque essas adaptações permitiriam o acesso a recursos que representam "refúgios competitivos" (Robinson \& Wilson 1998). Outra possibilidade para a expansão do nicho das espécies irmãs após a especiação seria a divergência morfológica ou comportamental sob vicariância, que pode ou não estar associada a seleção natural geograficamente variável (Thompson 2005), de forma que as novas interações evoluem independentemente em cada espécie emergente e não são necessariamente correlacionadas.

Espera-se que diferentes formas de reorganização do espaço de nicho decorrentes de variados modos de especiação tenham consequências distintas para propriedades estruturais das redes ecológicas, tais como conectância, aninhamento e modularidade (Fortuna et al. 2010). A especiação deve também influenciar a dinâmica ecológica em consequência da adição de espécies à comunidade e das mudanças por ela impostas aos padrões de interações bióticas (Abrams 1996; Jones \& Gomulkiewicz 2012). 


\section{Objetivos}

O conteúdo central desta tese é formado por três capítulos que combinam diferentes abordagens de modelagem a dados empíricos com o objetivo de investigar como a seleção natural atua sobre a estrutura, dinâmica e diversificação de assembleias de espécies mutualistas. O trabalho está focado, especificamente, na compreensão do papel central das interações ecológicas na origem e manutenção da biodiversidade. Por um lado, estudamos as condições em que interações como a competição e o mutualismo agem como mecanismo gerador de diferentes formas de seleção que moldam a evolução e diversificação fenotípica. Adicionalmente, modelamos a ação da seleção natural sobre as interações ecológicas, otimizando a abundância de espécies, reconfigurando a estrutura e alterando a dinâmica das assembleias mutualistas ao longo do tempo. Finalmente, investigamos como a reorganização das dimensões bióticas do nicho sob diferentes modos de especiação modificam a estrutura e dinâmica de redes mutualistas. Esses três momentos das pesquisas que alicerçam a tese são apresentados nos três capítulos subsequentes que, por sua vez, são seguidos por uma seção de Considerações Finais sobre o conjunto dos resultados aqui apresentados.

No Capítulo 2, combinamos modelos baseados em indivíduos e dados empíricos para estudar a ação conjunta e antagônica da competição intraespecífica e de mutualismos caracterizados por ajuste de traços ("trait matching") em cenários de diversificação adaptativa. Contrastamos previsões de nossos modelos e dados sobre a riqueza local de espécies em diversos sistemas mutualistas para discutir quais processos podem ser invocados para explicar a biodiversidade em mutualismos de alta e baixa intimidade.

Em seguida, no Capítulo 3, investigamos se a seleção natural atuando sobre os padrões de interações ecológicas das espécies pode explicar a variação estrutural observada em redes mutualísticas empíricas. Avaliamos se as redes simuladas que emergem de nossos modelos de reconfigurações adaptativas reproduzem os graus de aninhamento e modularidade empiricamente registrados para redes mutualistas de alta e baixa intimidade. Adicionalmente, utilizando análises de estabilidade local, investigamos as consequências dinâmicas das reconfigurações adaptativas, levando em conta diferentes suposições em relação aos regimes de competição interespecífica subjacentes às interações mutualísticas.

Por fim, no capítulo 4, retomamos o estudo da origem das espécies para modelar os efeitos de diferentes modos de especiação sobre a estrutura e dinâmica de redes mutualistas. Modelamos cenários em que a especiação têm diferentes consequências para a organização das dimensões bióticas do nicho - especificamente, aumentando ou diminuindo a amplitude 
de mutualistas interagindo com as espécies emergentes e definindo o grau de sobreposição entre elas em relação ao uso de recursos. Descrevemos as alterações estruturais nas redes ecológicas decorrentes da reorganização de nicho sob diferentes formas de especiação e inferimos suas consequência dinâmicas.

\section{Referências}

Abrams, P.A. (1996). Evolution and the consequences of species introductions and deletions. Ecology, 77, 1321-1328.

Allesina, S. \& Tang, S. (2012). Stability criteria for complex ecosystems. Nature, 483, 205208.

Anacker, B.L. \& Strauss, S.Y. (2014). The geography and ecology of plant speciation: range overlap and niche divergence in sister species. Proc. R. Soc. B., 281, 20132980.

Bascompte, J. \& Jordano, P. (2007). Plant-animal mutualistic networks: the architecture of biodiversity. Annu. Rev. Ecol. Evol. Syst., 38, 567-593.

Bascompte, J. \& Jordano, P. (2008). Redes mutualistas de espécies. Investigación y Ciéncia, Setembro, 50-59.

Bascompte, J. \& Jordano, P. (2014). Mutualistic networks. Princeton University Press, Princeton.

Bascompte, J., Jordano, P., Melián, C.J. \& Olesen, J. (2003). The nested assembly of plantanimal mutualistic networks. P. Natl. Acad. Sci. USA, 100, 9383-9387.

Bastolla, U., Fortuna, M.A., Pascual-García, A., et al. (2009). The architecture of mutualistic networks minimizes competition and increases biodiversity. Nature, 458, 1018-1020.

Bhattacharyay, A. \& Drossel, B. (2005). Modeling coevolution and sympatric speciation of flowers and pollinators. Physica A, 345, 159-172.

Bolnick, D.I., Svanbäck, R., Fordyce, J.A., Yang, L.H., Davis, J.M., Hulsey, C.D., et al. (2003). The ecology of individuals: incidence and implications of individual specialization. Am. Nat., 161, 1-28.

Brassil, C.E. (2012). Stability analysis. In: Encyclopedia of Theoretical Ecology (eds. Hastings, A. \& Gross, L.). University of California Press, Berkeley.

Bronstein, J.L. (2009). Mutualism and symbiosis. In: The Princeton Guide to Ecology (ed. Levin, S.). Princeton University Press, Princeton.

Dáttilo, W. (2012). Different tolerances of symbiotic and nonsymbiotic ant-plant networks to species extinctions. Netw. Biol., 2, 127-138.

Díaz-Castelazo, C., Sánchez-Galván, I.R., Guimarães, P.R., Jr, Raimundo, R.L.G. \& Rico- 
Gray, V. (2013). Long-term temporal variation in the organization of an ant-plant network. Ann. Bot., 111, 1285-1293.

Dieckmann, U. \& Doebeli, M. (1999). On the origin of species by sympatric speciation. Nature, 400, 354-357.

Dieckmann, U., Doebeli, M., Metz, J. \& Tautz, D. (2004). Adaptive speciation. The Press Syndicate of the University of Cambridge, Cambridge.

Doebeli, M. \& Dieckmann, U. (2000). Evolutionary branching and sympatric speciation caused by different types of ecological interactions. Am. Nat., 156, S77-S101.

Douglas, A.E. (1994). Symbiotic interactions. Oxford University Press, Oxford.

Dunne, J.A. (2006). The network structure of food webs. In: Ecological networks: linking structure to dynamics in food webs (eds. Pascual, M. \& Dunne, J. A.). Oxford University Press, Oxford.

Eldredge, N. (1985). Unfinished synthesis: biological hierarchies and modern evolutionary thought. Oxford University Press, Oxford.

Fisher, R.A. (1930). The genetical theory of natural selection. Oxford University Press, Oxford.

Fonseca, C.R. \& Ganade, G. (1996). Asymmetries, compartments and null interactions in an Amazonian ant-plant community. J. Anim. Ecol., 65, 339-347.

Fortuna, M.A., Stouffer, D.B., Olesen, J., Jordano, P., Mouillot, D., Krasnov, B.R., et al. (2010). Nestedness versus modularity in ecological networks: two sides of the same coin? $J$. Anim. Ecol., 79, 811-817.

Gavrilets, S. (2004). Fitness landscapes and the origin of species. Princeton University Press, Princeton.

Gómez, J.M., Verdú, M. \& Perfectti, F. (2010). Ecological interactions are evolutionarily conserved across the entire tree of life. Nature, 465, 918-921.

González-Avella, J.C., Cosenza, M.G., Herrera, J.L. \& Tucci, K. (2014). Emergence and persistence of communities in coevolutionary networks. Europhysics Letters, 107, 28002.

Gross, T. \& Blasius, B. (2008). Adaptive coevolutionary networks: a review. J. R. Soc. Interface, 5, 259-271.

Gross, T. \& Sayama, H. (2009). Adaptive networks. Heidelberg, Berlin.

Guimarães, P.R., Jr. (2009). A estrutura e a dinâmica evolutiva de redes mutualísticas. Ciência e Ambiente, 39, 137-148.

Guimarães, P.R., Jr, Jordano, P. \& Thompson, J.N. (2011). Evolution and coevolution in mutualistic networks. Ecol. Lett., 14, 877-885. 
Guimarães, P.R., Jr, Rico-Gray, V., Oliveira, P.S., Izzo, T.J., Reis, Dos, S.F.F. \& Thompson, J.N. (2007a). Interaction intimacy affects structure and coevolutionary dynamics in mutualistic networks. Curr. Biol., 17, 1797-1803.

Guimarães, P.R., Jr, Sazima, C., Reis, Dos, S.F.F. \& Sazima, I. (2007b). The nested structure of marine cleaning symbiosis: is it like flowers and bees? Biol. Lett., 3, 51-54.

Harary, F. (1994). Graph theory. Perseus Books, Cambridge.

Hembry, D. (2012). Coevolutionary diversification of leafflower moths (Lepidoptera: Gracillariidae: Epicephala) and leafflower trees (Phyllanthaceae: Phyllanthus sensu lato [Glochidion]) in southeastern Polynesia. Tese de Doutorado. Universidade da California, Berkeley.

Herrera, C.M. (1995). Plant-vertebrate seed dispersal systems in the Mediterranean: ecological, evolutionary, and historical determinants. Annu. Rev. Ecol. Syst., 705-727.

Herrera, C.M. (2000). Measuring the effects of pollinators and herbivores: evidence for nonadditivity in a perennial herb. Ecology, 81, 2170-2176.

Herrera, C.M. \& Pellmyr, O. (2002). Plant-animal interactions. Blackwell Science, Oxford.

Ito, H.C. \& Dieckmann, U. (2007). A new mechanism for recurrent adaptive radiations. Am. Nat., 170, E96-E111.

Jones, E.I. \& Gomulkiewicz, R. (2012). Biotic interactions, rapid evolution, and the establishment of introduced species. Am. Nat., 179, E28-E36.

Jordano, P., Bascompte, J. \& Olesen, J. (2003). Invariant properties in coevolutionary networks of plant-animal interactions. Ecol. Lett., 6, 69-81.

Kingsolver, J.G., Hoekstra, H.E., Hoekstra, J.M., Berrigan, D., Vignieri, S.N., Hill, C.E., et al. (2001). The strength of phenotypic selection in natural populations. Am. Nat., 157, 245261.

Krishna, A., Guimarães, P.R., Jr, Jordano, P. \& Bascompte, J. (2008). A neutral-niche theory of nestedness in mutualistic networks. Oikos, 117, 1609-1618.

Lewontin, R.C. (2000). The triple helix: gene, organism, and environment. Harvard University Press, Cambridge.

Loreau, M. (2010). Linking biodiversity and ecosystems: towards a unifying ecological theory. Philos. T. R. Soc. B, 365, 49-60.

Losos, J.B. \& Mahler, D.L. (2010). Adaptive radiation: the interaction of ecological opportunity, adaptation, and speciation. In: Evolution since Darwin: the first 150 Years (eds. Bell, M. A., Futuyma, D.J., Eanes, W.F. \& Levinton, J.S.). Sinauer Assoc., Sunderland.

Losos, J.B., Arnold, S.J., Bejerano, G., Brodie, E.D., III, Hibbett, D., Hoekstra, H.E., et al. 
(2013). Evolutionary Biology for the 21st century. Plos Biol., 11, e1001466.

May, R.M. (1973). Qualitative stability in model ecosystems. Ecology, 54, 638-641.

Maynard Smith, J. (1962). Disruptive selection, polymorphism and sympatric speciation, Nature, 195, 60-62.

McCann, K.S. (2000). The diversity-stability debate, Nature, 405, 228-233.

McKinney, M. L. \& Drake, J. A. (1998). Biodiversity dynamics: turnover of population, taxa, and communities. Columbia University Press, New York.

Mezquida, E.T. \& Benkman, C.W. (2014). Causes of variation in biotic interaction strength and phenotypic selection along an altitudinal gradient. Evolution, 68, 1710-1721.

Nonaka, E. (2014). Evolutionary consequences of ecological interactions. Tese de Doutorado. Universidade de Umeå, Suécia.

Nosil, P. (2012). Ecological speciation. Oxford University Press, Oxford.

Odling-Smee, F.J., Laland, K.N. \& Feldman, M.W. (2003). Niche construction: the neglected process in evolution. Princeton University Press, Princeton.

Olesen, J., Bascompte, J., Dupont, Y.L. \& Jordano, P. (2007). The modularity of pollination networks. P. Natl. Acad. Sci. USA, 104, 19891-19896

Olesen, J., Bascompte, J., Dupont, Y.L., Elberling, H., Rasmussen, C. \& Jordano, P. (2011). Missing and forbidden links in mutualistic networks. Proc. R. Soc. B, 278, 725-732.

Ollerton, J. (2006). "Biological barter": patterns of specialization compared across different mutualisms. In: Plant pollinator interactions: from specialization to generalization (eds. Waser, N.M. \& Ollerton, J.). University of Chicago Press, Chicago.

Paracer, S. \& Ahmadjian, V. (2000). Symbiosis: an introduction to biological associations. Oxford University Press, Oxford.

Patiny, S. (2012). Evolution of plant-pollinator relationships. Cambridge University Press, Cambridge.

Pelletier, F., Garant, D. \& Hendry, A.P.P. (2009). Eco-evolutionary dynamics. Philos. T. R. Soc. B, 364, 1483-1489.

Pfennig, D.W. \& Kingsolver, J.G. (2009). Phenotypic selection. In: The Princeton guide to Ecology (ed. Levin, S.). Princeton University Press, Princeton.

Pires, M.M. \& Guimarães, P.R., Jr. (2013). Interaction intimacy organizes networks of antagonistic interactions in different ways. J. R. Soc. Interface, 10, 20120649.

Poisot, T., Stouffer, D.B. \& Gravel, D. (2015). Beyond species: why ecological interaction networks vary through space and time. Oikos (no prelo). 
Post, D.M. \& Palkovacs, E.P. (2009). Eco-evolutionary feedbacks in community and ecosystem ecology: interactions between the ecological theatre and the evolutionary play. Philos. T. R. Soc. B, 364, 1629-1640.

Price, T. (2008). Speciation in birds. Roberts \& Company, Greenwood Village.

Ramos-Jiliberto, R., Valdovinos, F.S., Moisset de Espanés, P. \& Flores, J.D. (2012). Topological plasticity increases robustness of mutualistic networks. J. Anim. Ecol., 81, 896904.

Ricciardi, F., Boyer, M. \& Ollerton, J. (2010). Assemblage and interaction structure of the anemonefish-anemone mutualism across the Manado region of Sulawesi, Indonesia. Environ. Biol. Fish., 87, 333-347.

Robinson, B.W. \& Wilson, D.S. (1998). Optimal foraging, specialization, and a solution to Liem's paradox. Am. Nat., 151, 223-235.

Rooney, N. \& McCann, K.S. (2012). Integrating food web diversity, structure and stability. Trends Ecol. Evol., 27, 40-46.

Rosenzweig, M.L. (1978). Competitive speciation. Biol. J. Linn. Soc., 10, 275-289.

Schaeffer, R.N., Manson, J.S. \& Irwin, R.E. (2013). Effects of abiotic factors and species interactions on estimates of male plant function: a meta-analysis. Ecol. Lett., 16, 399-408.

Schluter, D. (1996). Ecological causes of adaptive radiation. Am. Nat., 40-64.

Schluter, D. (2000). The ecology of adaptive radiation. Oxford University Press, Oxford.

Siepielski, A.M. \& Benkman, C.W. (2009). Conflicting selection from an antagonist and a mutualist enhances phenotypic variation in a plant. Evolution, 64, 1120-1128.

Strauss, S.Y. \& Irwin, R.E. (2004). Ecological and evolutionary consequences of multispecies plant-animal interactions. Annu. Rev. Ecol. Evol. Syst., 35, 435-466.

Suweis, S., Simini, F., Banavar, J.R. \& Maritan, A. (2013). Emergence of structural and dynamical properties of ecological mutualistic networks, Nature, 500, 449-452.

Svanbäck, R. \& Bolnick, D.I. (2007). Intraspecific competition drives increased resource use diversity within a natural population. Proc. R. Soc. B., 274, 839-844.

Thébault, E. \& Fontaine, C. (2010). Stability of ecological communities and the architecture of mutualistic and trophic networks. Science, 329, 853-856.

Thompson, A.R., Adam, T.C., Hultgren, K.M. \& Thacker, C.E. (2013). Ecology and evolution affect network structure in an intimate marine mutualism. Am. Nat., 182, E58-E72.

Thompson, J.N. (1998). Rapid evolution as an ecological process, Trends Ecol. Evol., 13, 329-332. 
Thompson, J.N. (1999). The evolution of species interactions. Science, 284, 2116-2118.

Thompson, J.N. (2005). The geographic mosaic of coevolution. University of Chicago Press, Chicago.

Thompson, J.N. (2009). The coevolving web of life. Am. Nat., 173, 125-140.

Vázquez, D.P., Blüthgen, N., Cagnolo, L. \& Chacoff, N.P.P. (2009). Uniting pattern and process in plant-animal mutualistic networks: a review. Ann. Bot., 103, 1445-1457.

Waser, N.M. \& Ollerton, J. (2006). Plant-pollinator interactions: from specialization to generalization. University of Chicago Press, Chicago.

Zhang, F., Hui, C. \& Terblanche, J.S. (2011). An interaction switch predicts the nested architecture of mutualistic networks. Ecol. Lett., 14, 797-803. 


\title{
CApÍtulo 2
}

\section{Conflicting selection in the course of adaptive diversification: the interplay between mutualism and intraspecific competition}

\author{
Rafael L. G. Raimundo ${ }^{1}$, Jean P. Gibert ${ }^{2}$, David H. Hembry ${ }^{3+}$, and Paulo R. Guimarães Jr ${ }^{1 *}$ \\ ${ }^{1}$ Departamento de Ecologia, Instituto de Biociências, Universidade de São Paulo, Rua do \\ Matão, Travessa 14, no. 321, 05508-900, São Paulo, SP, Brazil \\ ${ }^{2}$ School of Biological Sciences, University of Nebraska - Lincoln, 410 Manter Hall, Lincoln, \\ Nebraska, 68588-0118 \\ ${ }^{3}$ Department of Environmental Science, Policy, and Management, University of California, \\ Berkeley, California, 94720 \\ ${ }^{+}$Current address: Center for Ecological Research, Kyoto University, 2-509-3 Hirano, Otsu, \\ Shiga 520-2113, Japan \\ *Corresponding author: prguima@usp.br
}

O manuscrito apresentado neste Capítulo 2 contém texto e demais conteúdos enviados à University of Chicago Press e publicado na The American Naturalist, conforme a seguinte referência:

Raimundo, R. L. G., J.-P. Gibert, D. H. Hembry, P. R. Guimarães Jr. Conflicting selection in the course of adaptive diversification: the interplay between mutualism and intraspecific competition. The American Naturalist 183 (3): 363-375.

Quaisquer citações devem referir-se à versão publicada do artigo, conforme supracitado. A reprodução, total ou parcial, dos conteúdos deste capítulo devem ser feitas necessariamente de acordo com a política de direitos autorais da The American Naturalist, a qual deve ser consultada no sítio de Internet da revista no seguinte endereço: http://www.press.uchicago.edu/ucp/journals/journal/an.html. 


\begin{abstract}
Adaptive speciation can occur when a population undergoes assortative mating and disruptive selection caused by frequency-dependent intraspecific competition. However, other interactions, such as mutualisms based on trait matching, may generate conflicting selective pressures that constrain species diversification. We used individual-based simulations to explore how different types of mutualism affect adaptive diversification. A magic trait was assumed to simultaneously mediate mate choice, intraspecific competition, and mutualisms. In scenarios of intimate, specialized mutualisms, individuals interact with one or few individual mutualistic partners and diversification is constrained only if the mutualism is obligate. In other scenarios, increasing numbers of different partners per individual limit diversification by generating stabilizing selection. Stabilizing selection emerges from the greater likelihood of trait mismatches for rare, extreme phenotypes than for common intermediate phenotypes. Constraints on diversification imposed by increased numbers of partners decrease if the trait matching degree has smaller positive effects on fitness. These results hold after the relaxation of various assumptions. When trait matching matters, mutualism-generated stabilizing selection would thus often constrain diversification in obligate mutualisms, such as ant-myrmecophyte associations, and in low-intimacy mutualisms, including plant-seed disperser systems. Hence, different processes, such as trait convergence favoring the incorporation of non-related species, are needed to explain the higher richness of low-intimacy assemblages - shown here to be up to one order of magnitude richer than high-intimacy systems.
\end{abstract}

\title{
Introduction
}

Frequency-dependent intraspecific competition can generate disruptive selection within a population, favoring rare extreme phenotypes and promoting sympatric speciation (Rosenzweig 1978). Speciation as a result of intraspecific competition for resources also depends on assortative mating (in which individuals mate preferentially with mates similar to themselves) within ecologically diverging subpopulations (Dieckmann et al. 2004). The notion that disruptive selection caused by frequency-dependent competition can lead to speciation if associated with non-random mating has been formalized under the theoretical framework of adaptive diversification (Doebeli 2011). Studies on wild populations support critical assumptions of adaptive diversification models, such as the commonness of disruptive 
selection (Kingsolver et al. 2001; Bolnick and Fitzpatrick 2007) and of traits that are under natural selection and that also affect mate choice ("magic traits", Servedio et al. 2011). On the other hand, adaptive diversification can often be constrained by conflicting forces, such as stabilizing selection caused by biotic interactions (Thompson 2005). Investigating scenarios of conflicting selection is thus a further step to deepen our understanding of how different types of ecological interactions shape adaptive diversification (Doebeli and Dieckmann 2000).

Organisms participate in several different types of interspecific interactions. These interactions exert potentially conflicting selective pressures, and their joint impact may shape diversification (Siepielski and Benkman 2009). Indeed, opposing selective pressures on the same trait exerted by different types of ecological interactions may be a ubiquitous phenomenon shaping phenotypic evolution and diversification (Strauss and Irwin 2004). The development of integrative frameworks exploring the interplay between intra and interspecific ecological interactions is required to improve our understanding of how basic attributes of ecological interactions are connected with patterns of diversification at the community level (Fontaine et al. 2011; Jones et al. 2012). Mutualisms based on trait complementarity - i.e., the functional matching between interacting species, such as the match between floral corolla depth and the length of hummingbird bills (Dalsgaard et al. 2008) - are examples of interspecific interactions that generate stabilizing selection and could counterweigh the diversifying effects imposed by intraspecific competition. Stabilizing selection emerges from trait complementarity because common intermediate phenotypes benefit more from mutualisms than do rare extreme phenotypes; the former are more likely to complement the most common local phenotypes of the other species (Thompson 2005). It is expected that this stabilizing effect will not be homogenous among different types of mutualisms because the wide variation in the natural history of mutualistic interactions should be associated with variable levels of dependence and species specificity (Bronstein 2009).

Indeed, different types of mutualisms vary in basic attributes that may affect diversification regimes. One of such attributes is the interaction intimacy, which is characterized by the degree of physiological integration and by the levels of physical and trophic dependence between the interacting species (Ollerton 2006; Fontaine et al. 2011). Symbiotic mutualisms are extreme cases of high-intimacy interactions in which individuals of one species (the symbiont) have an extensive physical and physiological integration with another species (the host), as exemplified by plant-Rhizobium associations (Bronstein 2009). As a consequence of a tight biological integration, individuals in high-intimacy systems tend 
to interact with few individuals of the other species during their lifetimes (Guimarães et al. 2007; Pires and Guimarães 2013). In contrast, seed dispersal systems illustrate low-intimacy mutualisms in which individuals of the interacting species have a low degree of biological integration and physical dependence (Ollerton 2006). Organisms involved in low-intimacy mutualisms may interact with many interspecific individuals during their lifetimes, as occur in interactions between plants with diverse seed dispersal strategies and generalist seed dispersers (Herrera 1995). Although interaction intimacy at the individual level is not necessarily correlated to specialization at the species level, there are well-known cases in which high interaction intimacy is correlated to high specialization, as occur in mutualisms between sea anemones and associated species of anemone fishes (Ricciardi et al. 2010). Conversely, low interaction intimacy at the individual level is often correlated to low specialization at the species level, as illustrated by generalized pollinators and generalistpollinated plants (Waser 1996).

Another feature of mutualistic interactions that can affect diversification regimes is the extent to which trait matching affects fitness. In nature, the degree of the positive impact of trait matching on fitness is highly variable. For instance, in organisms involved in intimate associations, mismatched individuals that are unable to perform mutualistic interactions may even be excluded from the mating pool, as occurs in associations between ants and myrmecophytes (Fonseca and Ganade 1996, Fonseca 1999). Similarly, the fitness consequences of mutualistic interactions between self-incompatible plants and specialized pollinators may be highly dependent on trait complementarity (Anderson and Johnson 2008; Thompson et al. 2013). However, phenotype matching may be less important in low-intimacy interactions between species involved in interspecific cooperative hunting (Minta et al. 1992; Bshary et al. 2006).

Here, we used individual-based simulations to assess how the interplay between mutualistic interactions and intraspecific competition affects adaptive diversification. We focused on mutualisms in which trait complementary between the interacting species plays a role in the fitness outcomes of the interaction (Bascompte and Jordano 2007). In nature, reciprocal fitness benefits commonly favors trait complementarity in various mutualistic systems, from pollination to plant protection by ants (Thompson 2005; Anderson and Johnson 2008, but see Anderson et al. 2010 for different mechanisms resulting in trait mismatches between mutualistic species). We thus incorporated mutualisms characterized by trait complementarity into a scenario of adaptive speciation. In doing so, we assumed that a magic trait mediates mate choice, intraspecific competition, and also affects mutualistic interactions 
(Bhattacharyay and Drossel 2005). For example, body size works as a magic trait in various taxa (Servedio et al. 2011) and is often involved in mutualistic trait complementarity, as exemplified by fitness advantages to ant queens whose body sizes match the sizes of available domatias of myrmecophytes (Fonseca 1999). Furthermore, two or more genetically correlated traits, one involved in divergent selection and other in assortative mating, can work as a magic phenotype that also mediates mutualistic interactions. For example, in Darwin finches (Geospiza spp.), beak morphology (which affects song patterns) and body size are considered a magic phenotype (Servedio et al. 2011). The same traits may mediate mutualisms in at least seven sympatric Geospiza species that are known to act as effective seed dispersers (Guerrero and Tye 2009).

We designed two simulation experiments to investigate how different types of ecological interactions at the individual level affect the diversification patterns observed at the species level. These simulation experiments encompass distinct scenarios for the interplay between the diversifying effects generated by intraspecific competition and the stabilizing effects of mutualisms. In a first simulation experiment, we investigated species diversification in the case of an intimate, specialized association in which individuals have few mutualistic partners and the interaction has a high impact on fitness. Specifically, we explored the effects on diversification imposed by the fates of individuals that remain without any mutualistic partner. We contrasted simulations in which individuals unable to perform mutualistic interactions persist in the mating pool (as in non-obligate mutualisms) to simulations in which they are removed from the population and thus are unable to reproduce (as in obligate mutualisms). In a second simulation experiment, we explored the effects imposed by different types of mutualisms on diversification. To simulate different types of mutualisms, we varied two interaction attributes associated to the interaction intimacy: (i) the number of different individual partners with which individuals interact and (ii) the effect of the degree of phenotype matching on fitness.

\section{The model}

We used individual-based models to simulate phenotypic evolution in a pair of freeliving species, $A$ and $B$, which are reciprocally involved in mutualistic interactions. Both species reproduce sexually in discrete, non-overlapping generations. The individuals of each species are characterized by magic traits $z_{A}$ and $z_{B}$, which mediate intra- and interspecific ecological interactions and influence mate choice. The initial values of $z_{\mathrm{A}}$ and $z_{B}$ are assigned 
by sampling from Gaussian distributions with means $\overline{z_{A}}$ and $\overline{z_{B}}$ and standard deviations $\sigma_{A}$ and $\sigma_{B}$, respectively. During a given time step, individuals (i) face environmental stabilizing selection (which excludes selective pressures imposed by competition and mutualism), (ii) experience intraspecific competition, (iii) engage in mutualistic interactions, (iv) reproduce, and die. We defined $N_{A}$ as the number of individuals in species $A$ or of all species derived from $A$ and $N_{B}$ as the number of individuals of species $B$ or of all species derived from $B$. The same numbers of individuals $N_{A}=N_{B}$ are born at each time step. To simulate populations at the carrying capacity, $N_{A}$ and $N_{B}$ are constant over time, implying intraspecific competition is relevant to ecological dynamics. We later relax these assumptions. Further details are given below.

Stabilizing selection. Stabilizing selection accounts for all selective pressures on traits $z_{A}$ and $z_{B}$ imposed by the environment, excluding those exerted by intraspecific competition and mutualism. Any given individual $i$ of a species $K$ (with $K$ being $A, B$, or the species originating from $A$ or $B$ ) displaying the phenotype $z_{K_{i}}$ has a survival probability $P_{\text {surv }}\left(z_{K_{i}}\right)$, defined as:

$$
P_{\text {surv }}\left(z_{K_{i}}\right)=\exp \left[-\gamma\left(z_{K_{i}}-\theta_{K}\right)^{2}\right]
$$

where $\theta_{K}$ is the phenotype of species $K$ favored by stabilizing selection and $\gamma$ is degree of sensitivity of that individual to stabilizing selection, which is equal for $A$ and $B$. For a fixed value of $z_{K_{i}}$, as $\gamma$ increases, $P_{\text {surv }}\left(z_{K_{i}}\right)$ decreases from 1 (no selection) to approximately 0 (strong selection). To simulate environment-induced mortality, we randomly assign a number, $r_{Z_{K}}$, sampled from a uniform distribution between 0 and 1 , to each individual $i$. Individual $i$ dies if $r_{z_{K_{i}}}>P_{\text {surv }}\left(z_{K_{i}}\right)$ (Yoder and Nuismer 2010).

Intraspecific competition. We assume that conspecific individuals with similar phenotypes $\left(z_{K_{i}}=z_{K_{j}}\right)$ compete more intensively than do more dissimilar individuals. Consequently, competition among individuals for resources that are extrinsic to the mutualistic interaction results in frequency-dependent disruptive selection. The function describing the competition between two individuals of species $K$ with phenotypes $z_{K_{i}}$ and $z_{K_{j}}$ is: 


$$
\alpha\left(z_{K_{i}}, z_{K_{j}}\right)=\exp \left[-c\left(z_{K_{i}}-z_{K_{j}}\right)^{2}\right]
$$

such that higher $c$ is associated with stronger competition (Bürger et al. 2006). The function $P_{\text {comp }}$ describes the effect of frequency-dependent intraspecific competition on individuals' mating probabilities. We assume that competition linearly reduces $P_{\text {comp }}$. Furthermore, in our baseline model, we assumed that the fitness components arising from ecological interactions affect only females mating probabilities (see the section "Relaxation of Assumptions" below for the alternative scenario in which ecological interactions also affects the males mating probabilities). The effect of competition on a female $i$ of a species $K$ is defined by:

$$
P_{\text {comp }}\left(z_{K_{i}}\right)=\frac{1-\bar{\alpha}\left(z_{K_{i}}\right)}{\max _{p}\left(1-\bar{\alpha}\left(z_{K_{p}}\right)\right)}, p=1,2, \ldots, N_{K_{f}}
$$

Here, $\bar{\alpha}\left(z_{K_{i}}\right)$ is the average intraspecific competition faced by an individual $i$ with phenotype $Z_{K_{i}}$ with respect to all other individuals within the population. $N_{K_{f}}$ is the number of females within the population of the species $K$. The denominator of equation 3 rescales the values of $P_{\text {comp }}\left(z_{k_{i}}\right)$ to the largest degree of intraspecific competition endured by females in the population, thus providing a proxy for the relative female fitness component arising from intraspecific competition. An equivalent relative fitness component can be computed for males in a similar way. In the baseline model, we assume that both species experience intraspecific competition. We later relax this assumption.

Mutualisms. Individuals of species $B$ (or of the species derived from $B$ ) evaluate and select mutualistic partners of species $A$ (or of the species derived from $A$ ), simulating common interactions between organisms that actively choose mutualistic partners (e.g., animals) and organisms being chosen (e.g., plants) (Bronstein et al. 2006). Interactions are based on trait complementarity. For simplicity, we assume that higher complementarity occurs when $z_{A_{i}}=$ $Z_{B_{i}}$. Every individual $i$ of species $B$ interacts with a fixed number $\omega_{B_{i}}$ of individuals from species $A$ bearing the most complementary traits. Therefore, the number $\omega_{A_{i}}$ of different partners with which each individual $i$ of species $A$ interacts is variable and defined by the attractiveness of its phenotype $\left(z_{A_{i}}\right)$ to individuals of species $B$ (Gómez and Perfectti 2012). The fitness component arising from the benefits gained from the mutualistic interactions for a 
female $i$ of species $A$ with phenotype $z_{A_{i}}, P_{m u t}\left(z_{A_{i}}\right)$, depends on the degree of trait complementarity between that female and the number $\omega_{A_{i}}$ of interacting interspecific individuals it encounters during its life span, as defined by the following equation:

$$
P_{m u t}\left(z_{A_{i}}\right)=\left(\frac{1+\sum_{j=1}^{N_{B}} \rho_{i j} \exp \left[-\left(z_{A_{i}}-z_{B_{j}}\right)^{2}\right]}{\max _{p}\left(1+\sum_{q=1}^{N_{B}} \rho_{p q} \exp \left[-\left(z_{A_{p}}-z_{B_{q}}\right)^{2}\right]\right)}\right)^{\lambda}, p=1,2, \ldots, N_{A_{f}},
$$

in which $\rho_{i j}=1$ if individual $i$ interacts with individual $j$ or zero otherwise. The number of interspecific individuals interacting with the female $i$ of the species $A$ is thus $\omega_{A_{i}}=\sum_{j=1}^{N_{B}} \rho_{i j}$. $N_{A_{f}}$ is the number of females within the population of the species $A$. Here the denominator rescales the values of $P_{\text {mut }}$, hence providing a proxy for the relative female fitness component arising from mutualistic interactions. The parameter $\lambda$ measures the effect of the degree of phenotype matching on fitness. The negative effect of increased trait mismatching on fitness thus increases as $\lambda$ increases. We assumed that $\lambda$ varies between 0 and 1 . We used $\lambda=1$ as the maximal effect of phenotypic matching on fitness. In this case, equation (4) is similar to the equation describing the fitness consequences of phenotypic matching used in previous works (e.g., Yoder \& Nuismer 2010). When $0<\lambda<1$, mismatched interactions are progressively less penalized under decreasing values of $\lambda$ (Online Appendix A, fig. A1). If $\lambda=0$, mutualism has no impact on the mating probability of individuals. The reproductive outcome of mutualistic interactions for a female $i$ of species $B$ is computed according to the same scheme.

Mate choice, reproduction, and death. Each female of species $K$ (with $K$ being species $A$ or $B$ or the species derived from them) with phenotype $z_{K i}$ has a mating probability $P_{m a t}$ $\left(z_{K_{i}}\right)$, determined by the reproductive penalty imposed by intra-specific competition $P_{\text {comp }}\left(z_{K_{i}}\right)$ and the reproductive outcome of the mutualistic interaction, $P_{m u t}\left(z_{K_{i}}\right)$, as defined by:

$$
P_{m a t}\left(z_{K_{i}}\right)=\frac{P_{\text {comp }}\left(z_{K_{i}}\right) \times P_{m u t}\left(z_{K_{i}}\right)}{\sum_{j=1}^{N_{K_{f}}} P_{\text {comp }}\left(z_{K_{j}}\right) \times P_{m u t}\left(z_{K_{j}}\right)} .
$$


For each offspring, a parental female is sampled with replacement with a probability given by $P_{\text {mat }}\left(z_{K_{i}}\right)$. That female mates with the male bearing the most similar trait value. The mating pair generates a single offspring individual with a trait value defined by the mean of the parental trait values plus or minus segregation variance, modeled as a random number sampled from a Gaussian distribution with mean $\bar{V}_{A}=0$ and standard deviation $\sigma_{V_{A}}=0.05$. All individuals die after reproducing, and their offspring become the next generation.

\section{Number of different mutualistic partners and impact of trait matching on fitness}

Models of mutualisms often assume that only a single pairwise interaction between individuals occurs. Nevertheless, a variable number of individual partners may have important effects on the ecological and evolutionary dynamics of mutualisms (Guimarães et al. 2007; Gokhale and Traulsen 2012). We thus investigated the effect of partner number on adaptive diversification by varying the number of different individual mutualistic partners $\left(\omega_{B}\right)$ for each individual $i$ of species $B$. Intimate mutualisms, such as those between ants and myrmecophytes, are cases in which individuals (a plant or ant colony) have low $\omega_{B}$. In contrast, low-intimacy mutualists, such as nectarivorous insect pollinators, have large $\omega_{B}$. One could expect individuals to interact with the same optimal partner multiple times because this partner provides the highest fitness benefit. However, in mutualisms among free-living species, individuals interact with multiple partners due to: interspecific competition (Palmer et al. 2003), high temporal variation in partner availability (Tarayre 2007), increased predation risk when visiting the most rewarding partners (Jones 2010), and reward variability among partners, such as inter-individual variability in amino acid composition of nectar within plant populations (Lanza et al. 1995).

In nature, the number of partners with which an individual interacts is variable. However, to test the effects of the number of interacting partners in a controlled way, we assumed that $\omega_{B}$ is fixed, meaning that all individuals of species $B$ interact with the same number of different mutualistic partners. On the other hand, individuals of species $A$ have no constraints on the number of different partners with which they can interact; therefore, $\omega_{A}$ depends on the choice patterns of the individuals of species $B$. This difference implies an asymmetry between species regarding the number of individual mutualistic partners per individual. Asymmetry in the number of interspecific partners occurs, for example, when plants produce abundant resources that can be used by many individual animals, but each 
animal interacts with only a few individual plants (Bentley 1977; Weiblen 2002). Complementarily, we examined the case in which individuals of both species have constraints on the total number of partners during their lifetimes (Online Appendix A).

We also investigated the consequences for adaptive diversification of having variable impacts of the mutualism trait matching on fitness. Varying $\lambda$ (equation 4 ) changes the effect of the degree of trait matching on the fitness component arising from the mutualistic interaction, thus affecting individuals' mating probabilities (fig. A1). High $\lambda$ values simulate scenarios in which the degree of trait matching strongly affects the reproductive output of an individual, with mismatched individuals being highly penalized, as in the case of selfincompatible plants and specialized pollinators (Anderson and Johnson 2008). At the other extreme, minimal $\lambda$ values simulate mutualisms in which the degree of trait matching has weak reproductive effects, as is likely the case for interspecific cooperative hunting, such as that between the badger, Taxidea taxus, and the coyote, Canis latrans (Minta et al. 1992).

\section{Simulation experiments}

We performed a sensitivity analysis (Online Appendix A) to identify the parameter combination resulting in greater species diversification. This parameter combination $\left(\sigma_{A}=\sigma_{B}\right.$ $\left.=0.58, \gamma=10^{-3}, c=0.74\right)$ defined the baseline scenario for two simulation experiments designed to explore the hypothesis that mutualism attributes constrain adaptive diversification. In our simulations, a species was heuristically defined as any phenotypic cluster including reproductively isolated individuals that is differentiated from other phenotypic clusters by a distance of at least 0.2 units of $z_{K}$. Comparisons of species richnesses among simulations were possible because the number of emerging species reached asymptotic levels before 1,000 time steps. See the Online Appendix A for further details on species delimitation.

Experiment 1: Intimate mutualisms, mating pool composition, and diversification

In the first simulation experiment, we modeled an intimate specialized mutualism to investigate how alternative reproductive outcomes for individuals that fail to perform mutualistic interactions affect diversification. The first simulation group (Group 1 - Control) modeled evolution in the absence of mutualism $\left(\omega_{B}=\lambda=0\right)$, with individual mating 
probabilities depending exclusively on $P_{\text {comp }}$. In Groups 2 and 3, species coevolve through mutualism, defined by $\omega_{B}=\lambda=1$. Therefore, in Groups 2 and 3, each individual of species $B$ interacts with only one mutualistic partner, and the degree of trait matching has a strong impact on its reproductive output. Individuals of species $A$ may interact with an unrestricted number of interspecific individuals $\left(\omega_{A}\right)$. However, for low $\omega_{B}$, some individuals of species $A$ will not have any mutualistic interactions (Online Appendix A). Groups 2 and 3 exhibit contrasting potential reproductive consequences for individuals of species $A$ that do not have any mutualistic interactions. In Group 2, individuals without mutualistic partners are able to reproduce (i. e., the mutualism is not obligate). For individuals without mutualistic partners, the numerator of equation 4 is equal to one, since in this case the summation of mutualistic trait matching effects is equal to zero. In Group 3, individuals without mutualistic interactions do not survive to mate (i. e. the mutualism is obligate). We ran 50 simulation replicates in each group with $\sigma_{A}=\sigma_{B}=0.58, \gamma=10^{-3}, \theta_{A}=0, \theta_{B}=1, c=0.74$, and $\lambda=1$. Pairwise differences in the mean asymptotic richness between these groups were tested using Tukey's HSD test.

The asymptotic species richnesses of control simulations (Group 1, $\omega_{B}=0, \overline{S_{A}}=7.5 \pm$ 1.1 species; $\overline{S_{B}}=7.3 \pm 0.94$ species) are not significantly different from the richnesses observed in simulations of non-obligate mutualisms (Group 2), in which individuals that fail to engage in interspecific interactions remain in the mating pool $\left(\omega_{B}=1, \overline{S_{A}}=7.2 \pm 0.92\right.$ species; $\overline{S_{B}}=7.05 \pm 1.05$ species; Tukey's HSD test, $Q=2.36, P>0.050$ for $S_{A}$ and $S_{B}, \mathrm{n}=$ 150). However, when individuals of species $A$ that fail to engage in mutualistic interactions are not permitted to mate (obligate mutualisms, Group 3), the mean asymptotic species richnesses are significantly lower than those of control simulations $\left(\omega_{B}=1, \overline{S_{A}}=6.75 \pm 0.91\right.$ species; $\overline{S_{B}}=6.60 \pm 0.83$ species; Tukey’s HSD test, $\left.Q=2.36, P<0.001, \mathrm{n}=150\right)$.

\section{Experiment 2: The effect of different types of mutualism on diversification}

To explore the effects of different types of mutualism on diversification, we simulated 30 scenarios (with 20 replicates for each) defined by the number of different individual partners, $\omega_{B}(1,2,4,8,16,32,64,128,256$, and 512) and by the magnitude of the impact of trait matching on fitness, $\lambda(0.01,0.1$, and 1$)$. Since the maximum value of $\omega_{B}$ is relatively low, we assumed that, for the range of $\omega_{B}$ values considered here, the net benefits of 
mutualism do not saturate under increased number of partners. Preliminary analyses showed that for $\omega_{B}>4$ all individuals of species $A$ interact (Online Appendix A, fig. A7). We investigated the scenario in which individuals of species $A$ without mutualistic partners are able to mate (as in Group 2 in Experiment 1), controlling the potential confounding effect of removing individuals from mating pool in simulations in which $\omega_{B}<4$ (Experiment 1). To control for the effects of mutualisms on diversification, we ran 20 additional simulations without mutualistic interactions $\left(\omega_{B}=\lambda=0\right)$. In each replicate, we counted the asymptotic richness of species derived from $A\left(S_{A}\right)$ and $B\left(S_{B}\right)$ after 1,000 time steps. We tested the effects of $\omega_{B}$ and $\lambda$ on diversification using general linear models (GLMs) in which the values of $\omega_{B}$ and $\lambda$ were log-transformed to improve normality and homoscedasticity.

Both the number of individual mutualistic partners $\left(\omega_{B}\right)$ and the effect of the degree of trait matching on fitness $(\lambda)$ affect species richness emerging from adaptive diversification (figs. 1 and 2). Richness is inversely correlated with the number of different individual partners, $\omega_{B}$. Indeed, $S_{A}\left(\mathrm{GLM}, F_{2617}=322.4, P<0.001, \mathrm{n}=620\right)$ and $S_{B}\left(\mathrm{GLM}, F_{2617}=\right.$ 263.4, $P<0.001, \mathrm{n}=620$ ) decrease as individuals of species $B$ interact with a greater number of mutualistic partners (i.e., with increasing $\omega_{B}$ values). An increased impact of the degree of trait matching on fitness (increasing $\lambda$ ) also constrains species diversification (GLM, $F_{2617}=$ 185.7 and $F_{2617}=309.9$, for $S_{A}$ and $S_{B}$, respectively; $P<0.001, \mathrm{n}=620$; fig. 2 ). When trait matching has a strong impact on the mating probabilities of individuals $(\lambda=1)$, a higher number of different individual mutualistic partners $\left(\omega_{B}\right)$ leads to decreased phenotypic variance (fig. 1) and also progressively constrains the emerging species richness (fig. 2A). A decrease in diversification with the increase in the number of individual mutualistic partners $\left(\omega_{B}\right)$ is also observed when the impact of trait matching on mating probabilities $(\lambda)$ is decreased by an order of magnitude (fig. 2B). Although species richness is lower when $\omega_{B} \geq$ 64, extreme $\omega_{B}$ values do not impose additional constraints on species diversification at lower $\lambda$ values (fig. 2B). The effect of $\omega_{B}$ on richness disappears when $\lambda$ is very small (0.01) because the effect of the mutualism is not sufficient to impose the necessary stabilizing selection (fig. 2C).

\section{Relaxation of assumptions}

We explored the dynamics of the model under the relaxation of different assumptions about mutualistic interactions, selection regimes, and population densities. Relaxing these 
assumptions allowed us to explore the dynamics of the IBM under alternative biological scenarios.

Phenotype matching. In experiments 1 and 2, individuals of species $B$ always choose a number $\omega_{B}$ of mutualistic partners that represent the best trait matches in the entire population of species $A$. Therefore, individuals are assumed to be able to evaluate all existing interspecific individuals. We relaxed this unrealistic assumption by performing a simulation in which each individual $i$ of species $B$ randomly chooses its mutualistic partner(s) from a subset of the population of $A$ formed by individuals within a certain phenotype range. This range is defined for each individual $i$ of species $B$ as a percentage $\psi$ of individuals of species $A$ bearing the traits most similar to its trait $z_{B_{i}}$. We ran 20 replicates for each combination of four $\psi$ values $(15 \%, 30 \%, 45 \%, 60 \%)$ with four $\omega_{B}$ values $(1,8,32,64)$ and $\lambda=1$. We then used a GLM to estimate the effects of $\psi$ and $\omega_{B}$ in this set of simulations. This alternative phenotype-matching scheme leads to a more intense constraint on diversification due to mutualism than is observed in experiments 1 and 2. The larger the subset of potential partners $\psi$, the lower the final species richness (GLM, $F_{2317}=135.2$ and $F_{2317}=176.6$ for $\overline{S_{A}}$ and $\overline{S_{B}}$, respectively; $P<0.001, \mathrm{n}=320)$. Nevertheless, the constraints imposed by the number of partners $\left(\mathrm{GLM}, F_{2317}=87\right.$ and $F_{2317}=80.4$ for $\overline{S_{\mathrm{A}}}$ and $\overline{S_{\mathrm{B}}}$, respectively; $\left.P<0.001, \mathrm{n}=320\right)$ still hold after relaxing the assumption of best-fit phenotype matching in our baseline model.

$P_{m u t}$ computation. Similar constraining effects of increasing the number of mutualistic partners on diversification arise if the impact of mutualism on reproduction does not depend on the quantity of individual mutualistic partners but rather on how beneficial the interactions are on average, i.e., if $\boldsymbol{P}_{m u t}$ is computed using the mean instead of the sum to aggregate the effect of interaction events in Equation 4 (Online Appendix A).

Males under selective pressures arising from ecological interactions. In our baseline model, only females have mating probabilities defined by two fitness components arising from ecological interactions, $P_{\text {comp }}$ and $P_{m u t}$ (equations 3-5). Therefore, for males, mating probabilities are determined exclusively by females' choice, since each breeding female chooses a male with the most similar trait value as its sexual partner. In order to investigate if our model results hold if males are also affected by the selective pressures generated by ecological interactions, we explored the effects of the number of individual mutualistic partners, $\omega_{B}$, and of the impact of the degree of trait matching on fitness, $\lambda$, when the male mating pool is formed by a percentage $(50 \%$ or $25 \%)$ of the original male subpopulation. The 
probability that a male will remain in the population to form the mating pool is computed following equations 3-5, but with $N_{A_{m}}$ and $N_{K_{m}}$, the number of males within the population of the species $A$ and $K$, replacing $N_{A_{f}}$ and $N_{K_{f}}$, respectively. We found that the effects of $\omega_{B}$, and $\lambda$ in these simulations in which ecological interactions also affect males' survival and in our baseline model are qualitatively the same (Online Appendix A).

Both species with limited numbers of individual mutualistic partners. We relaxed the assumption that only species $B$ has constraints on the number of mutualistic partners with which individuals interact. Increasing the number of interacting partners also reduces diversification if both species are constrained in the number interacting individuals $\left(\omega_{A}=\omega_{B}\right.$, Online Appendix A).

Only one species under disruptive selection. When we relaxed the assumption that both species are experiencing disruptive selection, similar effects of $\omega_{B}$ and $\lambda$ on diversification emerge when only species $B$ faces disruptive selection caused by intraspecific competition (Online Appendix A). However, diversification is even more constrained when species $A$, which is the one being chosen within the mutualistic interaction, experiences disruptive selection due to intraspecific competition (Online Appendix A).

Asymmetric population sizes. We explored the diversification dynamics when the population sizes of species $A$ and $B$ are asymmetric. We used values of $N_{B}<N_{A}$, leading to increased competition among individuals of species $A$ for mutualistic partners. We ran 20 replicates for three values of $N_{B}(75,150,300)$ and four $\omega_{B}$ values $(1,8,32,64)$ under $\lambda=1$ and $N_{A}=600$. The population size of species $B\left(N_{B}\right)$ affects the diversification of both species. Lower $N_{B}$ is associated with a lower final richness of species derived from species $B$ (GLM, $F_{2237}=168.3$ and $F_{2237}=327.7$ for $\overline{S_{\mathrm{A}}}$ and $\overline{S_{\mathrm{B}}}$, respectively; $P<0.001, \mathrm{n}=240$ ). This result is a consequence of stronger stabilizing selection imposed by the competition among individuals of $A$ for the fewer individuals of $B$. After controlling for the effect of $N_{B}$, the number of partners, $\omega_{B}$, still imposes constraints on diversification similar to those detected in Experiment $2\left(\mathrm{GLM}, F_{2237}=187.1\right.$ and $F_{2237}=97.6$ for $\overline{S_{\mathrm{A}}}$ and $\overline{S_{\mathrm{B}}}$, respectively; $P<0.001, \mathrm{n}$ $=240$ ).

Stochastic variation of population sizes. To relax the assumption of constant population sizes, we modeled two different scenarios for population variation across time. In the first model, the overall numbers of individuals $N_{B}$ and $N_{A}$ varied independently and randomly around a mean. At each generation, the number of individuals is the initial population size $\left(N_{A}=N_{B}=600\right)$ summed to a parameter $e$ with a value sampled from a 
Gaussian distribution with a mean of zero and a standard deviation of $\sigma_{P(K)}$. This stochastic variation in population size had a small but significant effect, constraining diversification $\left(\mathrm{GLM}, F_{2237}=5.7\right.$ and $F_{2237}=0.6$ for $\overline{S_{A}}$ and $\overline{S_{B}}$, respectively; $\left.P<0.001, \mathrm{n}=240\right)$. After controlling for the effect of population fluctuations, the number of mutualistic partners, $\omega_{B}$, still had an important effect of constraining diversification $\left(F_{2237}=467.2\right.$ and $F_{2237}=297.7$ for $\overline{S_{A}}$ and $\overline{S_{B}}$, respectively; $P<0.001, \mathrm{n}=240$ ). In a second scenario, we modeled more drastic variations in the overall number of individuals. From initial population sizes $N_{O(A)}=$ $N_{O(B)}=600$, the number of individuals $N_{t(K)}$ of a species at generation $t$ is $N_{t-1(K)}+V$, where $V$ is a percentage of $N_{t-1(K)}$. At any given generation, $V$ is randomly assigned to be positive or negative. We contrasted the diversification dynamics under two values of $\omega_{B}(8,32)$ and $V$ $(1 \%, 5 \%)$. In the resulting population dynamics, population sizes are uncorrelated, independently assuming values much lower or much higher than the original sizes. Despite such severe variation in population sizes, the general trend of decreased species diversification following increasing $\omega_{B}$ persisted (Online Appendix A).

\section{Discussion}

The interplay between disruptive and stabilizing selection shapes the phenotypic variability of natural populations (Bürger 2002). These selective forces are thought to be equally common in nature (Kingsolver et al. 2001) and are likely to act together within populations (Felsenstein 1979). They thus have the potential to jointly affect the selective regimes underpinning the adaptive origin of new species. Indeed, conflicting selection pressures can affect the microevolutionary processes involved in phenotypic divergence and speciation (Lankinen and Larsson 2009). Our simulations indicate that, even under strong disruptive selection and assortative mating, mutualisms based on phenotype matching can constrain diversification in different ways.

First, mutualisms in which individuals have few partners can constrain diversification if the interaction determines which individuals are able to mate. Extreme phenotypes thus become less frequent in the mating pool even if they benefit from low intraspecific competition. Direct dependence on mutualism for reproduction occurs when species rely on interspecific interactions for mating, as in the case of self-incompatible plants in relation to pollinators (Bond 1994). Additionally, in obligate mutualisms, individuals that fail to interact with partners suffer severe reproductive consequences. For example, ant queens that are excluded in the competition for a limited number of myrmecophyte plants are unable to 
survive and reproduce (Fonseca 1999). In other cases, plant individuals with maladapted myrmecophilic traits are attacked by herbivores and fail to reach reproductive size due to a lack of protection by ants (Léotard et al. 2008). Our analyses show that the emerging species richness depends on the population sizes of interacting species. Indeed, larger population sizes increase rates of adaptive diversification (Stevens et al. 2007). We thus expect that the magnitude of the constraints imposed on diversification by the exclusion of individuals without mutualistic interactions from the mating pool would be lower for species with larger population sizes.

Second, increasing the number of different mutualistic partners constrained specieslevel diversification even when we relaxed our biological assumptions regarding how phenotype matching occurs, population densities, and the number of species under disruptive selection. The generality of these results suggests that stabilizing selection may often inhibit the diversification caused by disruptive selection in mutualisms involving many individual partners. Here, the sources of stabilizing selection are increased suboptimal matches arising from an increased number of different individual mutualistic partners. As the number of different interacting individuals increases, the stabilizing selection imposed by the escalating effects of trait mismatch on extreme phenotypes progressively counterbalances the disruptive selection caused by intraspecific competition. If rare extreme phenotypes need many different mutualistic partners, they face a higher degree of interaction mismatches than do common intermediate phenotypes. Furthermore, the stabilizing effect is amplified as more players become involved in mutualistic interactions and a larger proportion of the extreme phenotypes of the population are affected by suboptimal choices; the magnitude of such mismatches also increases (fig. 3).

The effects of intraspecific competition favoring extreme phenotypes may thus be reduced or even suppressed when mutualistic interactions involving multiple players are an important factor affecting fitness. Our simulations also show that increasing values of $\omega_{B}$, the number of different mutualistic partners with which the individuals of species $B$ interact, constrain the overall phenotypic variance within a clade, leading to progressively lower phenotypic distances among the emerging species. Decreased phenotypic distances between similar, related species may lead to strong interspecific competition, constraining intrapopulation variation. Thus, we hypothesize that selective pressures imposed by low-intimacy mutualisms add strength to the constraints imposed by interspecific competition to intrapopulation variation (Bolnick et al. 2003), potentially affecting ecological and evolutionary dynamics. For example, decreased phenotypic distances among the emerging species would 
impose sufficient interspecific competition to constrain species' niche width and avoid the continuous formation of extreme phenotypic clusters.

Our second simulation experiment suggests that adaptive diversification would emerge in mutualisms in which the degree of trait matching strongly affect fitness (high $\lambda$ ) and each individual interacts with few partners (low $\omega_{B}$ ) - even if only one species experiences the disruptive selection regime. Conversely, the simulations predict that adaptive diversification in low-intimacy mutualisms (large $\omega_{B}$ ) will often be constrained by strong stabilizing selection generated by phenotype mismatch in extreme phenotypes, counteracting the effect of disruptive selection. However, low-intimacy mutualistic assemblages hold up to one order of magnitude more species than high-intimacy assemblages in nature (fig. 4 and Online Appendix A). The departure between the patterns observed in nature and the predictions derived from our model provide insights on the role of different evolutionary processes in shaping the diversity of mutualistic assemblages.

Our model predicts that the species-rich assemblages formed by low-intimacy mutualisms are not likely to be a result of adaptive diversification promoted by intraspecific competition. As a consequence, other evolutionary processes are needed to explain the observed patterns of species richness in these systems. One possibility is that in low-intimacy mutualisms, which often form species-rich networks, a highly interactive set of generalist species drives the evolution of the whole assemblages (Bascompte et al. 2003; Guimarães et al. 2011) and favor, through convergence and complementarity of traits, the incorporation of new non-related species into the assemblages (Thompson 2009). Therefore, low-intimacy mutualistic systems can become species-rich by aggregating non-related species over time (Ramírez et al. 2011). Another non-exclusive hypothesis is that some low-intimacy mutualisms, such as seed dispersal by vertebrates, may indirectly promote diversification by providing predictable resources and broadening geographic ranges. For example, species of mutualistic primates have large geographic ranges, which favor high geographic speciation rates and low extinction rates (Gómez and Verdu 2012).

On the other hand, our first simulation experiment does predict constraints to diversification in high-intimacy, obligate mutualisms (when individuals that fail to interact with mutualistic partners are excluded from the mating pool), such as pollination by flower parasites. Complementarily, other processes can also constrain species diversification in these high-intimacy mutualisms, leading to relatively species-poor systems. First, high-intimacy mutualisms can be more prone to species extinctions and coextinctions (Dáttilo 2012), which can contribute to lower local species richnesses despite of a higher diversification potential. 
Additionally, high-intimacy mutualisms are embedded in tight coevolutionary processes involving complex sets of integrated traits (Thompson et al. 2013). As a consequence, highintimacy systems are taxonomically constrained and have a very low potential to pull in nonrelated species into the interaction network. Indeed, events of addition of outside taxa to highintimacy assemblages are few, even over tens of millions of years (Pellmyr 2003; Kawakita and Kato 2009).

The generality of our predictions rely on the major assumption that magic traits are involved in mutualistic interactions. An in-depth examination of this assumption requires more data on phenotypic selection and mating preferences in mutualisms. However, there is empirical evidence suggesting that magic traits can be found in intimate interactions, such as size-based assortative mating in anemone fish subjected to intense intraspecific competition (Hattori 2012). Moreover, the costs of assortative mating often constrain sympatric speciation (Bolnick and Fitzpatrick 2007). These costs may be reduced in highly intimate mutualisms as female choosiness becomes more viable due to a reduction of risks (e.g., predation) and search time. Moreover, the greater morphological, physiological, and behavioral integration between mutualistic partners found under intimate specialized mutualisms may favor the occurrence of automatic magic traits - the case in which prezygotic reproductive isolation by assortative mating is a byproduct of trait evolution under disruptive selection (Servedio et al. 2011). Indeed, assortative mating is likely to occur when individuals mate in time- or spacedefined groups. For example, divergence in the timing of oviposition in relation to host phenology may initiate speciation in pollinating seed-parasitic globeflower flies (Ferdy et al. 2002) and the co-speciation of fig wasps and their hosts (Kiester et al. 1984). Conversely, the strength of assortative mating may be constrained in low-intimacy mutualisms due to viability costs (Rymer et al. 2010) Weak assortative mating may thus be an additional limiting factor constraining adaptive diversification in low-intimacy systems.

In conclusion, we argue here that conflicting selection pressures generated by intraand interspecific ecological interactions have important consequences for our understanding of adaptive diversification. We have shown a general effect in which stabilizing selection generated by mutualistic trait complementarity constrains the adaptive diversification caused by intraspecific competition. These results hold under various biological assumptions and represent a first step in the study of conflicting selection during diversification in mutualistic assemblages. However, although trait complementarity is common (Dalsgaard et al. 2008), other interaction mechanisms, such as trait differences (Yoder and Nuismer 2010) or the interaction mechanisms assumed in game theoretical models of mutualisms (e. g., Gokhale 
and Traulsen 2012) are also recurrent in mutualisms and may impose alternative selection regimes that will interact with the disruptive selection caused by intraspecific competition to produce distinct outcomes in terms of species diversity. Investigating the effects of such alternative interaction mechanisms on adaptive diversification is a promising line of research addressing the broader challenge of describing the fundamental role of competition in the evolution of mutualisms (Jones et al. 2012).

\section{Acknowledgments}

We are indebted to D. Bolnick, G. S. van Doorn, P. Jordano, I. Karonen, G. Machado, F. Marquitti, M. Pires, T. Priklopil, E. Sebastián-Gonzáles, J. N. Thompson, and two anonymous reviewers for comments and suggestions. RLGR was supported by the São Paulo Research Foundation, FAPESP (grant 2011/13054-6) and CAPES. PRG was supported by FAPESP (grant 2009/54422-8). RLGR thanks the ESF Programme FroSpects and FICS for the opportunity to attend the Helsinki Summer School on Mathematical Ecology and Evolution. The University of Nebraska-Lincoln supported JPG through an Othmer Fellowship and SBS. DHH was supported by the Department of Environmental Science, Policy, and Management at the University of California, Berkeley, and a postdoctoral fellowship from the Japan Society for the Promotion of Science.

\section{Literature Cited}

Anderson, B., and S. D. Johnson. 2008. The geographical mosaic of coevolution in a plantpollinator mutualism. Evolution 62: 220-225.

Anderson, B., J. S. Terblanche, and A. G. Ellis. 2010. Predictable patterns of trait mismatches between interacting plants and insects. BMC Evolutionary Biology 10: 204.

Bascompte, J., P. Jordano, C. J. Melián, and J. Olesen. 2003. The nested assembly of plantanimal mutualistic networks. Proceedings of the National Academy of Sciences of the United States of America 100: 9383-9387.

Bascompte, J., and P. Jordano. 2007. Plant-animal mutualistic networks: the architecture of biodiversity. Annual Review of Ecology, Evolution and Systematics 38: 567-593. 
Bentley, B. L. 1977. Extrafloral nectaries and protection by nectaries and pugnacious body guards. Annual Review of Ecology and Systematics 8: 407-427.

Bhattacharyay, A, and B. Drossel. 2005. Modeling coevolution and sympatric speciation of flowers and pollinators. Physica A 345: 159-172.

Bolnick, D. I., R. Svanbaeck, J. A. Fordyce, L.H. Yang, J.M. Davis, C.D. Hulsey, and M.L. Forister. 2003. The ecology of individuals: incidence and implications of individual specialization. The American Naturalist 161: 1-28.

Bolnick, D. I., and B. M. Fitzpatrick. 2007. Sympatric speciation: models and empirical evidence. Annual Review of Ecology, Evolution, and Systematics 38: 459-487.

Bond, W J. 1994. Do mutualisms matter? Assessing the impact of pollinator and disperser disruption on plant extinction. Philosophical Transactions of the Royal Society B: Biological Sciences 344: 83-90.

Bronstein, J. L., R. Alarcón, and M. Geber. 2006. The evolution of plant-insect mutualisms. New Phytologist 172: 412-428.

Bronstein, J. L. 2009. Mutualism and Symbiosis. Pages 233-238 in S. A. Levin (ed.). The Princeton Guide to Ecology. Princeton University Press, Princeton, USA.

Bshary, R., A. Hohner, K. Ait-el-Djoudi, and H. Fricke. Interspecific communicative and coordinated hunting between groupers and giant moray eels in the Red Sea. Plos Biology 4: e431.

Bürger, R. 2002. On a genetic model of intraspecific competition and stabilizing selection. The American Naturalist 160: 661-682.

Bürger, R., K. A. Schneider, and M. Willensdorfer. 2006. The conditions for speciation through intraspecific competition. Evolution 60: 2185-2206.

Dalsgaard, B., A. M. Martin-Gonzalez, J. M. Olesen, A. Timmermann, L. H. Andersen, and J. Ollerton. 2008. Pollination networks and functional specialization: a test using Lesser Antillean plant-hummingbird assemblages. Oikos 117: 789-793. 
Dáttilo, W., 2012. Different tolerances of symbiotic and nonsymbiotic ant-plant networks to species extinctions. Network Biology 2: 127-138.

Dieckmann, U., M. Doebeli, J. A. J. Metz, and D. Tautz. 2004. Adaptive speciation. Cambridge University Press, Cambridge.

Doebeli, M. 2011. Adaptive diversification. Princeton University Press, New Jersey.

Doebeli, M., and U. Dieckmann. 2000. Evolutionary branching and sympatric speciation caused by different types of ecological interactions. The American Naturalist 156: S77-S101.

Felsenstein, J. 1979. Excursions along the interface between disruptive and stabilizing selection. Genetics 93: 773-795.

Ferdy, J.-B., L. Després, and B. Godelle. 2002. Evolution of mutualism between globeflowers and their pollinating flies. Journal of Theoretical Biology 217: 219-234.

Fonseca, C. R., and G. Ganade. 1996. Asymmetries, compartments and null interactions in an Amazonian ant-plant community. Journal of Animal Ecology 65: 339-347.

Fonseca, C. R., 1999. Amazonian ant-plant interactions and the nesting space limitation hypothesis. Journal of Tropical Ecology 15: 807-825.

Fontaine, C., P. R. Guimarães Jr, S. Kéfi, N. Loeuille, J. J. Memmott, W. H. van der Putten, F. J. F. van Veen, and E. Thébault. 2011. The ecological and evolutionary implications of merging different types of networks. Ecology Letters 14: 1170-1181.

Gokhale, C. S., and A. Traulsen. 2012. Mutualism and evolutionary multiplayer games: revisiting the Red King. Proceedings of the Royal Society B: Biological Sciences 279: 46114616.

Gómez, J. M. and F. Perfectti. 2012. Fitness consequences of centrality in mutualistic individual-based networks. Proceedings of the Royal Society B: Biological Sciences 279: 1754-1760.

Gómez, J. M., and M. Verdu. 2012. Mutualism with plants drives primate diversification. Systematic Biology 61: 567-577. 
Guerrero, A. M. and A. Tye. 2009. Darwin's finches as seed predators and dispersers. The Wilson Journal of Ornithology 121: 752-764.

Guimarães, P. R, Jr, V. Rico-Gray, P. S. Oliveira, T. J. Izzo, S. F. Reis, and J. N. Thompson. 2007. Interaction intimacy affects structure and coevolutionary dynamics in mutualistic networks. Current Biology 17: 1797-1803.

Guimarães, P. R., Jr, P. Jordano, and J. N. Thompson. 2011. Evolution and coevolution in mutualistic networks. Ecology Letters 14: 877-885.

Hattori, A. 2012. Determinants of body size composition in limited shelter space: why are anemonefishes protandrous? Behavioral Ecology 23: 512-520.

Herrera, C M. 1995. Plant-vertebrate seed dispersal systems in the Mediterranean: ecological, evolutionary, and historical determinants. Annual Review of Ecology and Systematics 26: $705-727$.

Jones, E. I. 2010. Optimal foraging when predation risk increases with patch resources: an analysis of pollinators and ambush predators. Oikos 119: 835-840.

Jones, E. I., J. L. Bronstein, and R. G. Ferrière. 2012. The fundamental role of competition in the ecology and evolution of mutualisms. Annals of the New York Academy of Sciences 1256: 66-88.

Kawakita, A., and M. Kato. 2009. Repeated independent evolution of obligate pollination mutualism in the Phyllantheae-Epicephala association. Proceedings of the Royal Society B: Biological Sciences 276: 417-426.

Kiester, A.R., R. Lande, and D. W. Schemske. 1984. Models of coevolution and speciation in plants and their pollinators. The American Naturalist 124: 220-243.

Kingsolver, J. G., H. E. Hoekstra, J. M. Hoekstra, D. Berrigan, S. N. Vignieri, C. E. Hill, A. Hoang, P. Gibert, and P. Beerli. 2001. The strength of phenotypic selection in natural populations. The American Naturalist 157: 245-261.

Lankinen, Å., and M. C. Larsson. 2009. Conflicting selection pressures on reproductive 
functions and speciation in plants. Evolutionary Ecology 23: 147-157.

Lanza, J., G. C. Smith, S. Sack, and A. Cash. 1995. Variation in nectar volume and composition of Impatiens capensis at the individual, plant, and population levels. Oecologia 102: 113-119.

Léotard, G., A. Saltmarsh, F. Kjellberg, and D. McKey. 2008. Mutualism, hybrid inviability and speciation in a tropical ant-plant. Journal of Evolutionary Biology 21: 1133-1143.

Minta, S., K. Minta, and D. Lott. 1992. Hunting associations between badgers (Taxidea taxus) and coyotes (Canis latrans). Journal of Mammalogy 73: 814-820.

Ollerton, J. 2006. "Biological Barter": patterns of specialization compared across different mutualisms. Pages 411-435 in N. M. Waser and J. Ollerton (eds). Plant-pollinator interactions: from specialization to generalization. University of Chicago Press, Chicago.

Palmer, T. M., M. L. Stanton, and T. P. Young. 2003. Competition and coexistence: exploring mechanisms that restrict and maintain diversity within mutualist guilds. The American Naturalist 162: S63-S79.

Pellmyr, O. 2003. Yuccas, yucca moths, and coevolution: a review. Annals of the Missouri Botanical Gardens 90: 35-55.

Pires, M. M., and P. R. Guimarães Jr. 2013. Interaction intimacy organizes networks of antagonistic interactions in different ways. Journal of The Royal Society Interface, doi: 10.1098/rsif.2012.0649.

Ramírez, S. R., T. Eltz, M. K. Fujiwara, G. Gerlach, B. Goldman-Huertas, N. D. Tsutsui and N. E. Pierce. 2011 Asynchronous divergence in a specialized plant-pollinator mutualism. Science 333, 1742-1746.

Ricciardi, F., Massimo B., and J. Ollerton. 2010. Assemblage and interaction structure of the anemonefish-anemone mutualism across the Manado Region of Sulawesi, Indonesia. Environmental Biology of Fishes 87: 333-347.

Rosenzweig, M. L. 1978. Competitive speciation. Biological Journal of the Linnean Society 10: $275-289$. 
Rymer, P. D., S. D. Johnson, and V. Savolainen. 2010. Pollinator behaviour and plant speciation: can assortative mating and disruptive selection maintain distinct floral morphs in sympatry? New Phytologist 188: 426-436.

Servedio, M. R., G. S. van Doorn, and M. Kopp. 2011. Magic traits in speciation: 'magic' but not rare? Trends in Ecology \& Evolution 26: 389-397.

Siepielski, A. M., and C. W. Benkman. 2009. Conflicting selection from an antagonist and a mutualist enhances phenotypic variation in a plant. Evolution 64: 1120-1128.

Stevens, M. H. H., M. Sanchez, J. Lee, and S. E. Finkel. 2007. Diversification rates increase with population size and resource concentration in an unstructured habitat. Genetics 177: 2243-2250.

Strauss, S. Y., and R. E. Irwin. 2004. Ecological and evolutionary consequences of multispecies plant-animal interactions. Annual Review of Ecology, Evolution and Systematics 35: 435-466.

Tarayre, M., G. Bowman, A. Schermann-Legionnet, M. Barat, and A. Atlan. 2007. Flowering phenology of Ulex europaeus: ecological consequences of variation within and among populations. Evolutionary Ecology 21: 395-409.

Thompson, J. N. 2005. The geographic mosaic of coevolution. The University of Chicago Press, Chicago.

Thompson, J. N. 2009. Coevolution. Pages 247-252 in S. A. Levin (ed.). The Princeton Guide to Ecology. Princeton University Press, Princeton, USA.

Thompson, J. N., C. Schwind, P. R. Guimarães Jr, and M. Friberg. 2013. Diversification through multitrait evolution in a coevolving interaction. Proceedings of the National Academy of Sciences of the United States of America

Waser, N. M., L. Chittka, M. V. Price, N. M. Williams, and J. Ollerton. 1996. Generalization in pollination systems, and why it matters. Ecology 77: 1043-1060.

Weiblen, G.D. 2002. How to be a fig wasp. Annual Review of Entomology 47: 299-330. 
Yoder, J. B., and S. L. Nuismer. 2010. When does coevolution promote diversification? The American Naturalist 176: 802-817. 


\section{Figure Captions}

Figure 1. Mutualism attributes affect adaptive diversification. We consider sympatric populations of two mutualistic species, $A$ and $B$, both experiencing intra-specific, frequencydependent competition for resources. Mutualistic interactions are based on phenotypic matching, and the same trait mediates intraspecific competition and female mate choice. Individuals of species $B$ choose a limited number $\left(\omega_{B}\right)$ of mutualistic partners, whereas individuals of species $A$ have no constraints on the number of different interspecific individuals with which they interact. Here, the impact of mutualism trait matching on fitness is high because $\lambda=1$ (see equation 4). Females mate assortatively, and the product of the penalty imposed by intraspecific competition and the profit gained from mutualism defines individual mating probabilities. The color temperature indicates the density of individuals, ranging from high (hot colors) to low (cool colors). $\mathrm{N}_{\mathrm{A}}=\mathrm{N}_{\mathrm{B}}=600, \sigma_{A}=\sigma_{B}=0.58, \gamma=10^{-3}$, $\Theta_{A}=0, \Theta_{B}=1, c=0.74$.

Figure 2. Species richness achieved in the simulation experiment under variable mutualisms. Asymptotic species richness obtained in simulations with different mutualism attributes, namely, the number of different interspecific partners of individuals of species $B$ $\left(\omega_{B}\right)$ and the impact of mutualistic trait matching on the individual mating probabilities $(\lambda)$. Each panel shows species richnesses under variable $\omega_{B}$ values for mutualisms in which the degree of trait matching (A) has a high impact on fitness, (B) has an intermediate impact on fitness, or (C) has a low impact on fitness. Twenty replicate simulations were performed for each scenario. The horizontal lines inside the boxes indicate the medians. The boxes encompass the interquartile range, and error bars indicate the smallest (lower) and largest (upper) non-outliers. Outliers are plotted separately as points.

Figure 3. Phenotype mismatches in mutualistic interactions in which individuals of species $B$ have different numbers of mutualistic partners $\left(\omega_{B}\right) \cdot z_{A}$ and $z_{B}$ are the values for the traits mediating the mutualism in species $A$ and $B$, respectively. Panels show the distribution of trait mismatches for all interaction events within a timestep $t$, when individuals of species $B$ have (A) low number of different mutualistic partners, (B) intermediate number of different mutualistic partners, or (C) high number of different mutualistic partners. The color gradient from purple (0) to red (2.00) represents increasing trait mismatch in interaction events. In all panels, $t=1, \lambda=1$, and $\mathrm{N}_{\mathrm{A}}=\mathrm{N}_{\mathrm{B}}=600$.

Figure 4. Species richness in natural mutualistic assemblages. $S_{A}$ and $S_{B}$ indicate species richness for each group of mutualistic species (e.g. plants/pollinators). Black and red symbols indicate high- and low-intimacy mutualisms, respectively. Symbols represent different types of mutualism. Squares depict marine mutualisms (black = obligate interactions between anemone fish and their host species of sea anemones, red = cleaning mutualisms between cleaner species of shrimps and fishes and their fish clients). Triangles indicate antplant mutualisms (black $=$ specialized protection mutualisms between ants and myrmecophyte plants, red $=$ generalized ant-plant mutualisms, including protection mutualisms and antmediated seed dispersal). Crosses show pollination mutualisms (black $=$ highly specialized, obligate interactions between plants and pollinating seed parasites, red = interactions between animal pollinators and flowering plants). 


\section{Figure 1}
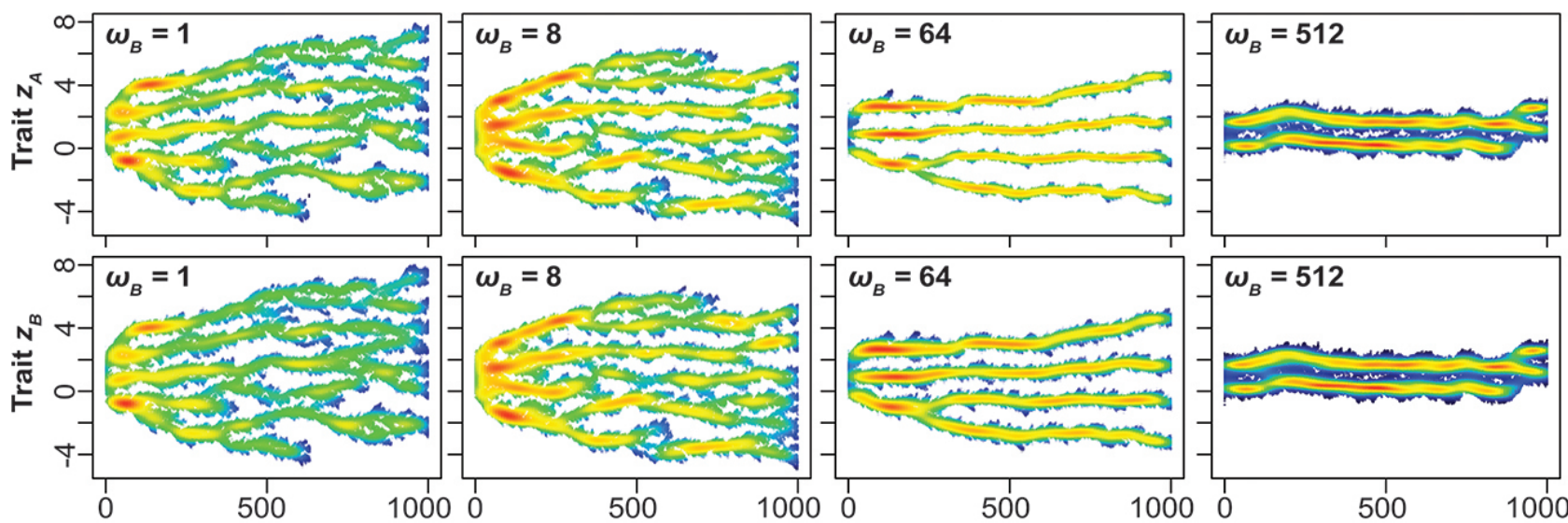

Time 


\section{Figure 2}

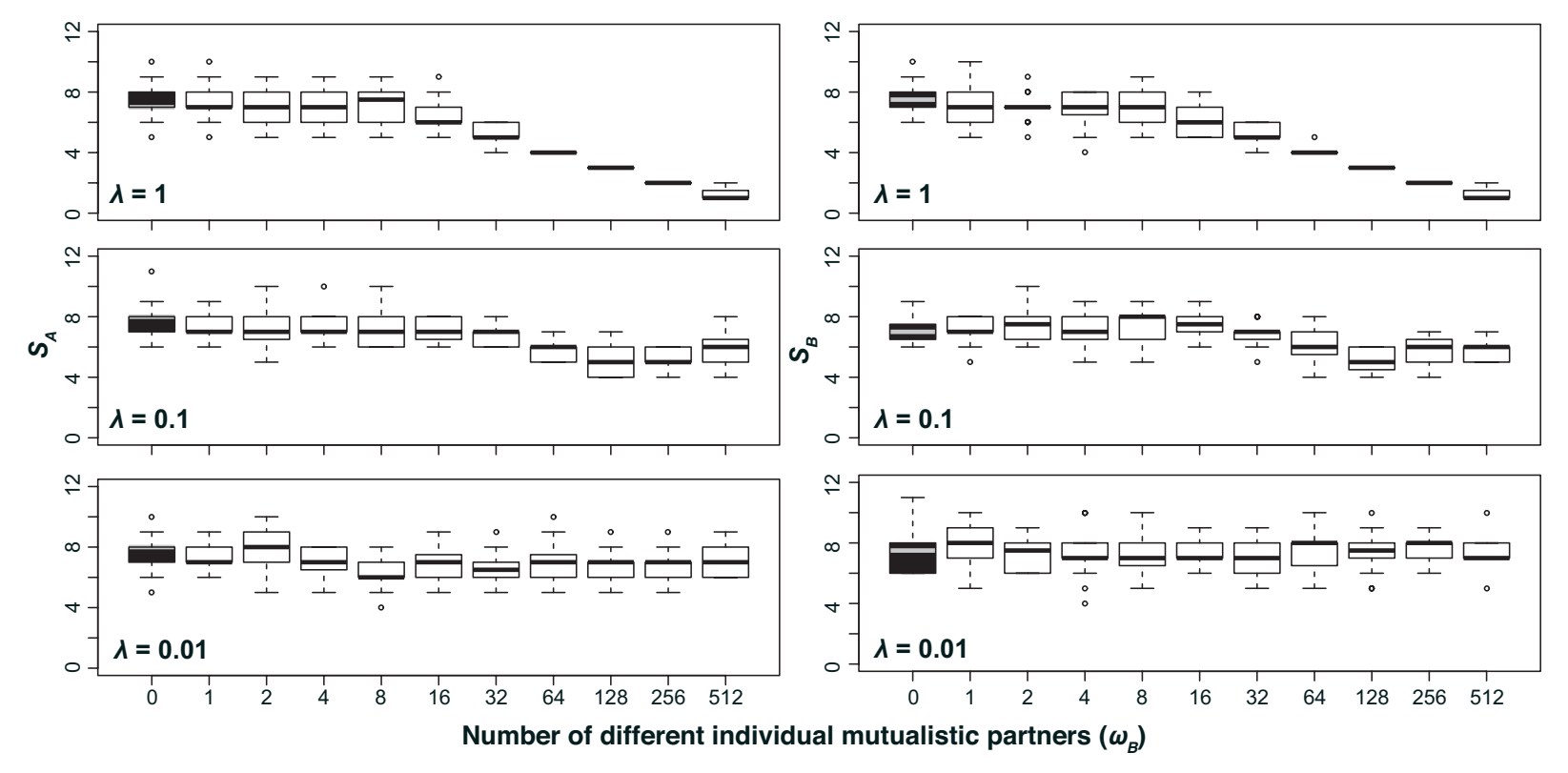


Figure 3
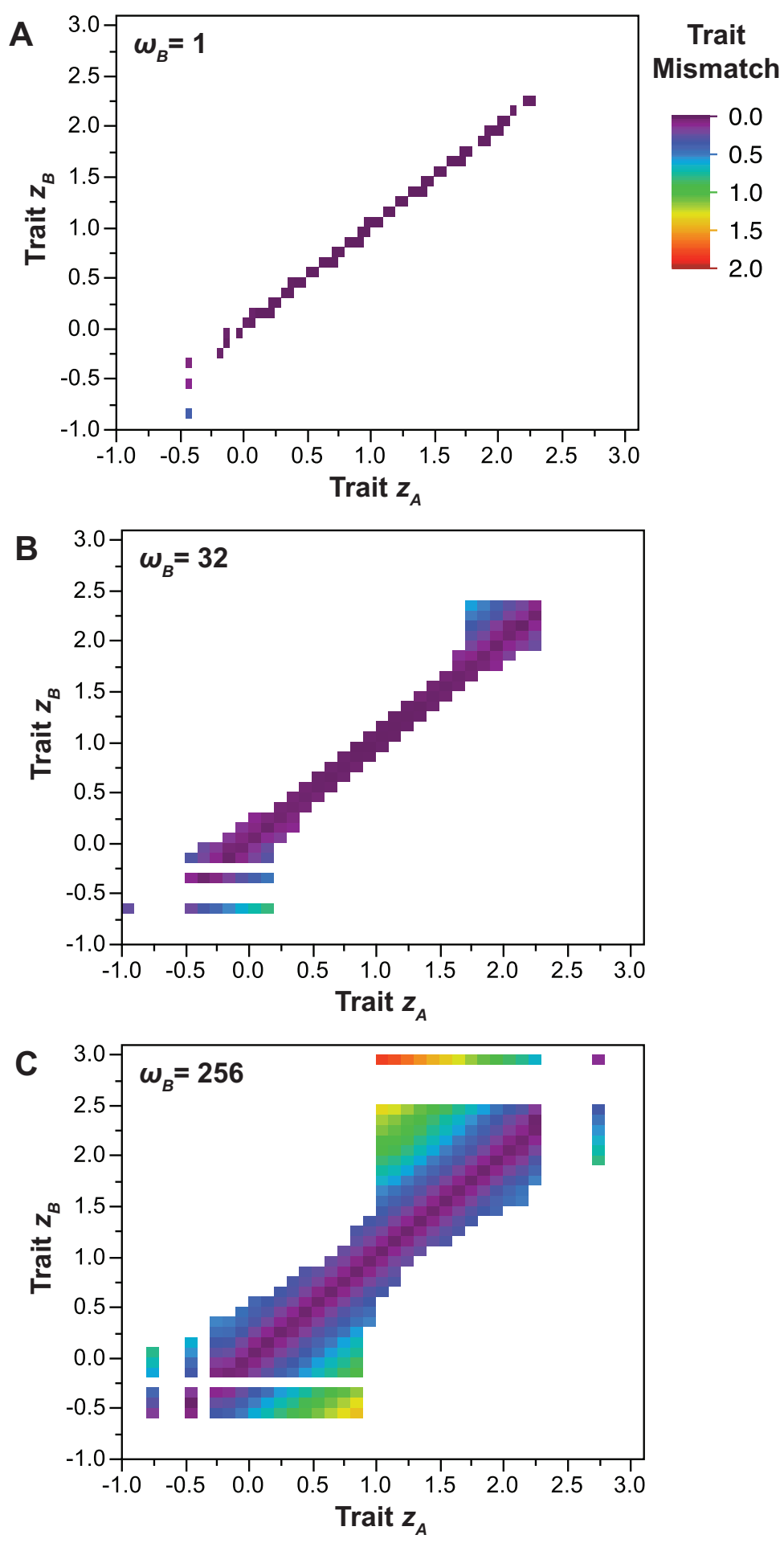
Figure 4

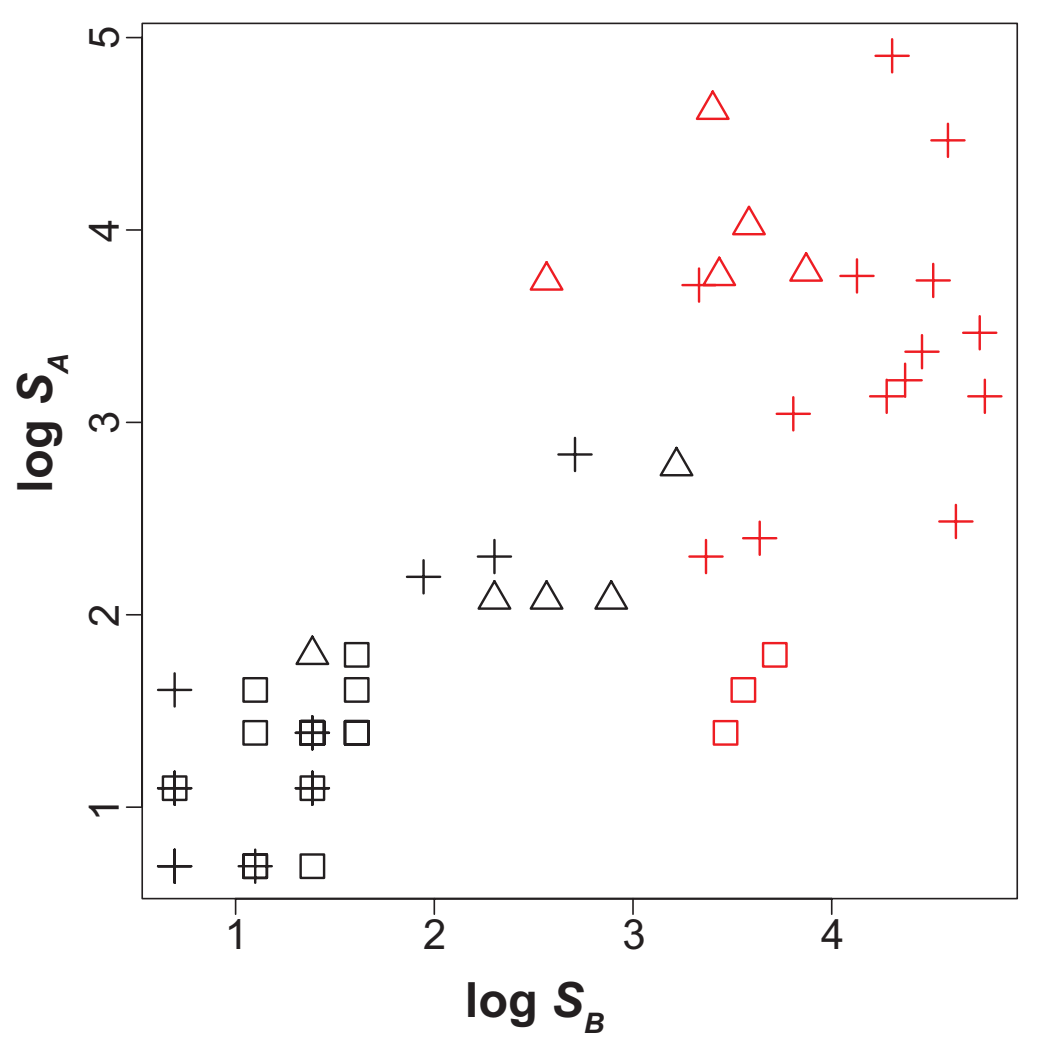




\section{ONLINE APPENDIX A - SUPPORTING INFORMATION}

\section{Conflicting selection in the course of adaptive diversification: the interplay between mutualism and intraspecific competition}

Rafael L. G. Raimundo, Jean P. Gibert, David H. Hembry, and Paulo R. Guimarães Jr

\section{Contents}

Impact of the degree of trait matching on mating probabilities ........................................... 56

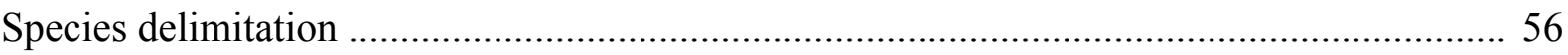

Asymptotic levels of diversity and stability of diversification patterns ................................ 58

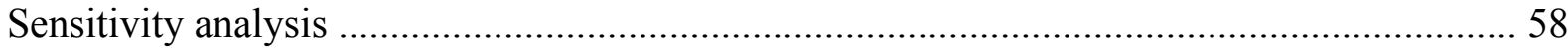

Alternative scenarios regarding biological assumptions …………………………………. 59

Mutualism impact on the mating pool composition ................................................. 59

Alternative $P_{\text {mut }}$ computation .......................................................................... 59

Symmetric constraint on the number of individual mutualistic partners .................... 60

Relaxing the assumption of both species under disruptive selection............................. 60

Relaxing the assumption of equal and constant population sizes ................................ 61

Males under selective pressures arising from ecological interactions ........................ 61

Species richness in natural mutualistic assemblages ...................................................... 62

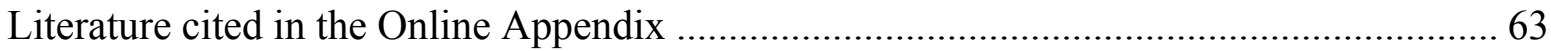

\section{Impact of the degree of trait matching on mating probabilities}

We used the parameter $\lambda$ (equation 4, main text) to describe the effect of the degree of trait matching of mutualistic interactions on the reproductive output of individuals. We assumed that $\lambda$ varies between 0 and 1 . If $\lambda=1$, increasing mismatches rapidly impose great reproductive loss (fig. A1-A). Mismatched interactions are progressively less penalized under decreasing values of $\lambda$ (figs. A1-B-C). As the parameter approaches 0 , the reproductive impact of trait matching becomes uniform within the population (fig. A1-D).

\section{Species delimitation}

We applied a phenotypic clustering criterion (PCC) to delimit species emerging in our simulations. Phenotypic clusters are often used for species delimitation in adaptive speciation 
models (Doebeli and Dieckmann 2000). We built an algorithm based on the discontinuous distribution of a trait $z$ to identify clusters defined by phenotypic discontinuities. The algorithm uses a parameter $l$ to define the degree of discontinuity separating ecologically differentiated and reproductively isolated individuals. To test the consistency of PCC in determining species identities in our simulations, we (i) compared species richness $(S)$ computed under different $l$ values to the number of lineages observed in phenotypic trajectory plots describing trait divergence through time, (ii) tracked individuals' genealogies to check for the existence of hybrids, i.e., individuals with parents belonging to different species, and (iii) examined phenotypic clusters to check if they hold individuals descending from more than one species. With regards to (i), species richness detected by PCC is overestimated if $l<$ 0.1 units of $z$, since individuals isolated by small phenotypic discontinuities, as those found in the extreme of each species distributions, are classified as unique species. For example, when $l=0.05$, the species delimitation rule recognizes up to 75 species deriving from species $A$ (fig. A2, blue line), whereas the actual number of lineages is much lower (fig. A3). A better estimate for species richness within our adaptive diversification model is found when $0.1 \leq l \leq$ 0.2 . Values of $l>>0.2$ underestimate species richness since ecologically specialized and reproductively isolated clusters are merged within the same species (fig. A2, black line). When $l=0.1$, even incipient divergence between clusters are computed in the richness count (fig. A3-B), whereas $l=0.2$ provides a more accurate approximation for the number of lineages observed in phenotypic trajectory plots (figs. A3-B, A3-D). Based on these results, we chose a value of $l=0.2$ for the species delimitation parameter used in our species richness analyses. With regards to (ii), phenotypic clusters emerging in our model can be interpreted as reproductively isolated units, since $100 \%$ of individuals had both parents belonging to the same cluster/species $(\mathrm{n}=60,000$ individuals sampled during 100 time steps uniformly distributed through 10,000 generations, $l=0.2$ ). Therefore, each phenotypic cluster results from assortative mating within a small number of genealogically linked individuals (families) (fig. A3-A). Finally, with regards to (iii), only a small fraction of individuals within a given cluster eventually descend from multiple species. We found that $97.5 \pm 10 \%$ of individuals per generation are assembled in clusters in which all organisms descend from a unique parental species $(n=60,000$ sampled during 100 time steps uniformly distributed through 10,000 generations, $l=0.2$ ). 


\section{Asymptotic levels of diversity and stability of diversification patterns}

We used the PCC algorithm to describe the temporal variation in species richness $(S)$ through 10,000 generations. The diversification patterns remained stable after 10,000 generations (Figure A4). Species richnesses reached asymptotic levels before 1,000 time steps (fig. A5). These results are consistent under different values of the mutualism attributes $\left(\omega_{B}\right.$ and $\lambda$ ). Similar asymptotic levels were also observed for another diversity measure, the Shannon-Weaver index $\left(H^{\prime}\right)$. We thus proceeded to compute species richness in simulation replicates using the number of species found by the PCC algorithm after 1,000 time steps.

\section{Sensitivity analysis}

We performed a sensitivity analysis using Latin hypercube sampling (Stein 1987, Carnell 2009) to explore the parametric space and identify parameter combinations resulting in greater species diversification. This sensitivity test considered a mutualism defined by $\omega_{B}=$ $\lambda=1$ to explore the model dynamics under variable initial trait variances $\left(\sigma_{A}=\sigma_{B}\right)$, strengths of stabilizing selection $(\gamma)$ and strengths of intraspecific competition $(c)$. We ran 20 simulations encompassing the sampled parametric combinations (Table A1) under four population sizes $\left(N_{A}=N_{B}=75,150,300\right.$, and 600 individuals), thus totaling 80 simulations. Figure A6 (A-D) shows the results of the sensitivity analysis for $N_{A}=N_{B}=150,300$, and 600 individuals.

Varying population sizes allowed us to assess the extent to which asymptotic richness depends on the number of individuals in the population. Higher population sizes associated with strong intraspecific competition and low environmental stabilizing selection promote the greatest degrees of species diversification $\left(\sigma_{A}=\sigma_{B}=0.58, \gamma=0.001, c=0.74\right)$. This parameter combination defined the baseline scenario for two simulation experiments designed to explore the hypothesis that mutualism attributes constrain adaptive diversification (see the main text).

The highest diversification degree - a radiation-like pattern with recurrent extinctions - thus arises when the strength of stabilizing selection, $\gamma$, is low $(<0.1)$. This pattern is particularly evident in larger populations (figs. A6s 1-s2). When $0.5>\gamma>0.1$, populations split into several stable phenotypic lineages (figs. A6s3-s10), except when the strength of intraspecific competition (c) decreases, which leads to a single branching event (fig, A6s8). When $\gamma>0.5$, results converge to a single branching event regardless of population size (fig. A6s11-s20), except if $c$ is low, in which case larger populations may hold polymorphisms 
without bifurcating (fig. A6s17-18). When $\gamma>0.1$, most small populations (75, 150 individuals) undergo a single branching event, or branching-extinction cycles if $c$ is near its maximum (fig. A6s6).

\section{Alternative scenarios regarding biological assumptions}

In the following sections, we explore the model dynamics under alternative biological assumptions in relation to those of our baseline model.

\section{Mutualism impact on the mating pool composition}

In our model, species $A$ is not limited regarding the number of interspecific partners individuals may have. Therefore, some individuals may interact much more times than others, whereas a proportion of the population may remain without mutualistic partners (fig. A7). The reproductive consequences for individuals remaining without any mutualistic partners could be: (i) reduced mating probabilities or (ii) preclusion from the mating pool. Indeed, highly intimate mutualisms can potentially filter individuals from the mating pool.

We thus ran additional simulations in which we assumed that if individuals of species $A$ were not selected by any mutualistic partner, they were also unable to mate $\left(P_{m a t}=0\right)$. Adaptive diversification is constrained when highly intimate mutualisms $\left(\omega_{B}=\lambda=1\right)$ act as mating filters (see the main text for detailed results). The relative frequency of extreme phenotypes with relatively high mating probabilities decreases, since those individuals that suffered low intraspecific competition but did not interact are precluded from the mating pool.

\section{Alternative $\mathrm{P}_{\mathrm{mut}}$ computation}

The fitness component $P_{m u t}$, describing the gain obtained by individuals from mutualistic interactions, was computed by summing up the outcome of each interaction event. Although $P_{m u t}$ is a standardized fitness component (equation 4 in main text), we tested if the progressive limit imposed to diversification by increasing values of $\omega_{B}$ could simply be a consequence of an additive effect of interaction events. If $P_{m u t}$ is computed based on the mean benefit acquired by individuals, and is therefore proportional to mean trait complementarity, the effect of $\omega_{B}$ on adaptive diversification is consistent with the results of our simulation experiment (fig. A8). 
Symmetric constraint on the number of individual mutualistic partners

In our simulation experiments, only individuals of species $B$ have a fixed number of mutualistic partners. Complementarily, we also explored an alternative scenario in which both species are constrained in relation to the number of partners with which individuals interact $\left(\omega_{A}=\omega_{B}\right)$. We defined a preference vector with mutualistic partners for each individual of species $B$ based on phenotype matching. Interaction occurred by rounds. In each round of interactions, the order of individuals of species $B$ choosing their preferred partner was randomly assigned. If a given individual of species $A$ reached $\omega_{A}$ interactions, it was removed from the mutualistic partner pool available for species $B$. In this scenario, in which individuals of both species have limits to the number of interaction events, the degree of diversification also drops following the increase in the value of $\omega_{A}=\omega_{B}$ (fig. A9).

\section{Relaxing the assumption of both species under disruptive selection}

We relaxed the assumption that both species are under disruptive selection. We ran 20 replicates for each combination of $\omega_{B}\left(\omega_{B}=8,64,512\right)$ and $\lambda$ values $(\lambda=0.1,1)$ for cases in which (i) only species $A$ is under disruptive selection, and (ii) only species $B$ experiences the disruptive regime.

Species richness is significantly lower (Tukey's HSD test, $Q=2.34, p<0.001$ ) in cases where species $A\left(S_{A}=3.88 \pm 2.23 \mathrm{spp}\right.$. and $\mathrm{SB}=4.00 \pm 2.35$ spp., $n=120$ simulations $)$ or species $B\left(S_{A}=1.28 \pm 0.58 \mathrm{spp}\right.$. and $S_{B}=1.19 \pm 0.41 \mathrm{spp} ., \mathrm{n}=120$ simulations $)$ are not subject to disruptive selection compared to the simulations in which both species experience a disruptive selective regime $\left(S_{A}=5.18 \pm 2.23\right.$ spp. and $S_{B}=5.3 \pm 2.3$ spp., $\mathrm{n}=120$ simulations, fig. A10). Despite such quantitative differences, similar effects of $\omega_{B}$ and $\lambda$ on diversification emerge if only species $B$ faces disruptive selection. However, diversification is severely constrained if only species $A$, the one with individuals being chosen within the mutualistic interaction, experiences the disruptive regime. In this case, a low degree of diversification occurs when the effect of mutualistic trait matching on fitness decreases (fig. A11). These results show that the degree of diversification achieved by $A$ is highly dependent on the selective regimes operating in its mutualistic partner, $B$. 
Relaxing the assumption of equal and constant population sizes

We relaxed the assumption that the overall number of individuals within each species or group of species is equal and constant over time. A first scenario of stochastic population dynamics, which is presented in the main text, assumes that each species' population varies randomly around a mean. At each generation, each species population size is defined by the initial population size $\left(N_{A}=N_{B}=600\right)$ summed to a parameter $e$ whose value is sampled from a Gaussian with mean equal to zero and standard deviation $\sigma_{P(K)}$ (see the main text for details and results).

In a second simulation, we allowed more drastic stochastic fluctuations of population sizes. Departing from initial population sizes of $N_{O(A)}=N_{O(B)}=600$, the number of individuals $N_{t(K)}$ of a species/guild at the generation $t$ is given by $N_{t-1(K)}+\mathrm{V}$, where $V$ is a percentage of $N_{t-}$ $1(K)$. At any given generation, $V$ is randomly assigned to be positive or negative. We contrasted the diversification dynamics under different values of $\omega_{B}(8,32)$ and $V(1 \%, 5 \%)$. In the resulting population dynamics, population sizes vary independently and can assume values much lower or much higher than the original sizes. Despite such a wide variation in population size, the general trend of decreased diversification following increasing $\omega_{B}$ is also observed (Figure A12). The trend is robust even for higher values of $\omega_{B}(64,128)$ and $V$ $(10 \%, 15 \%)$ (results not shown).

\section{Males under selective pressures arising from ecological interactions}

In our baseline model, only females have mating probabilities defined by two fitness components arising from ecological interactions, $P_{\text {comp }}$ and $P_{\text {mut }}$ (equations 3-5). Figure A13 shows the results of simulations in which males are also affected by the selective pressures generated by ecological interactions. We explored the effects of the number of different individual mutualistic partners, $\omega_{B}$, and of the impact of the degree of trait matching on fitness, $\lambda$, when the males mating pool is formed by a percentage ( $50 \%$ or $25 \%$ ) of the original males. The probability that a male will remain in the population to form the mating pool is computed following equations 3-5, but with $N_{A m}$ or $N_{K m}$, the number of males within the population of the species $A$ or $K$, replacing $N_{A f}$ or $N_{K f}$.

We found that the effects of $\omega_{B}$ and $\lambda$ are qualitatively the same when males are also subject to selective pressures arising from ecological interactions. However, the overall species diversification decreases in the extreme case in which only $25 \%$ of the original males 
form the mating pool, probably due to an additional source of stabilizing selection imposed by the reduced availability of mating males.

\section{Species richness in natural mutualistic assemblages}

We compiled a dataset summarizing species richness in 57 natural assemblages to describe species richness in high-intimacy (high $\lambda$, low $\omega_{B}$ ) and low-intimacy (variable $\lambda$, high $\omega_{B}$ ) local mutualistic assemblages. We thus contrasted species richnessess between groups of mutualistic assemblages in which the interacting individuals have different degrees of biological integration (Ollerton 2006). Variable degrees of interaction intimacy affect the organization of ecological interactions in different ways, with distinct consequences for the evolutionary and coevolutionary processes that shape species diversity (Guimarães et al. 2007, Fontaine et al. 2011, Pires and Guimarães 2013). We obtained data from the Interaction Web Database website, available in the address http://www.nceas.ucsb.edu/interactionweb/, and from the literature. References are provided in Table A2.

Data on high-intimacy mutualisms totalize 35 assemblages, including: obligate mutualisms between species of anemone fish and their host sea anemones (17 assemblages); intimate protection mutualisms between specialized ant species and myrmecophyte plants that provide housing and food to ant colonies (5 assemblages); highly specialized, obligate mutualisms between pollinating seed parasites and their host plant species (13 assemblages), encompassing interactions between figs and fig wasps (2 assemblages) and between Glochidion trees and Epicephala moths (11 assemblages).

Data depicting species richnessess in low-intimacy mutualisms totalize 22 assemblages, including: marine cleaning mutualisms involving cleaner species of shrimps or fishes removing ectoparasites and other material from their client fishes (3 assemblages); generalized ant-plant mutualisms, including ant-mediated seed dispersal ( 2 assemblages) and generalized ant-plant protection mutualisms ( 3 assemblages); and mutualisms between animal pollinators and flowering plant species (14 assemblages).

High-intimacy mutualistic assemblages are relatively species-poor $(\bar{S}=10.7 \pm 8.3$ species), with assemblages of anemones and anemone fishes and of plants and pollinating seed parasite holding the lowest species numbers. On the other hand, low-intimacy mutualisms have up to one order of magnitude more species $(\bar{S}=97.2 \pm 47.4$ species, $t=$ 11.5, $P<0.0001$ ), with plant-pollinator assemblages representing the richest systems (fig. 4 , main text). 


\section{Literature cited in the Online Appendix}

Arroyo, M. T. K., R Primack, and J. Armesto. 1982. Community studies in pollination ecology in the high temperate Andes of central Chile. I. Pollination mechanisms and altitudinal variation. American Journal of Botany 69: 82-97.

Azuma, H., R. D. Harrison, K. Nakamura, and Z. H. Su. 2010. Molecular phylogenies of figs and fig-pollinating wasps in the Ryukyu and Bonin (Ogasawara) islands, Japan. Genes \& Genetic Systems 85: 177-192.

Barrett, S. C. H., and K. Helenurm. 1987. The reproductive biology of boreal forest herbs. I. Breeding systems and pollination. Canadian Journal of Botany 65: 2036-2046.

Carnell, R. 2009. Lhs: Latin Hypercube Samples. R package version 0.5.

Davidson, D. W., R. R. Snelling, and J. T. Longino. 1989. Competition among ants for myrmecophytes and the significance of plant trichomes. Biotropica 21: 64-73.

Davidson, D. W., and B. L. Fisher. 1991. Symbiosis of ants with Cecropia as a function of light regime. Pages 289-309 in C. R. Huxley and D. F. Cutler (eds). Ant-plant interactions. Oxford University Press, Oxford.

Diaz-Castelazo, C., V. Rico-Gray, P. S. Oliveira, and M. Cuautle. 2004. Extrafloral nectarymediated ant-plant interactions in the coastal vegetation of Veracruz, Mexico: richness, occurrence, seasonality, and ant foraging patterns. Ecoscience 11: 472-481.

Doebeli, M., and U. Dieckmann. 2000. Evolutionary branching and sympatric speciation caused by different types of ecological interactions. The American Naturalist 156: S77-S101.

Dupont, Y. L., and D. M. Hansen. 2003. Structure of a plant-flower-visitor network in the high-altitude sub-alpine desert of Tenerife, Canary Islands. Ecography 26: 301-310.

Elberling, H., and J. M. Olesen. 1999. The structure of a high latitude plant-flower visitor system: the dominance of flies. Ecography 22: 314-323. 
Fonseca, C. R., and G. Ganade. 1996. Asymmetries, compartments and null interactions in an Amazonian ant-plant community. Journal of Animal Ecology 65: 339-347.

Fontaine, C., P. R. Guimarães Jr, S. Kéfi, N. Loeuille, J. J. Memmott, W. H. van der Putten, F. J. F. van Veen, and E. Thébault. 2011. The ecological and evolutionary implications of merging different types of networks. Ecology Letters 14: 1170-1181.

Frisch, A. J., and J-P. A. Hobbs. 2009. Rapid assessment of anemone and anemonefish populations at the Keppel Islands [electronic resource]: a report to the Great Barrier Reef Marine Park Authority. Research Publication no. 94, Great Barrier Reef Marine Park Authority, Commonwealth of Australia.

Guimarães, P. R, Jr, V. Rico-Gray, P. S. Oliveira, T. J. Izzo, S. F. Reis, and J. N. Thompson. 2007. Interaction intimacy affects structure and coevolutionary dynamics in mutualistic networks. Current Biology 17: 1797-1803.

Hembry, D. H. 2012. Coevolutionary diversification of leafflower moths (Lepidoptera: Gracillariidae: Epicephala) and leafflower trees (Phyllanthaceae: Phyllanthus sensu lato [Glochidion]) in Southeastern Polynesia. PhD Thesis. University Of California, Berkeley.

Hembry, D. H., A. Kawakita, N.E. Gurr, M.A. Schmaedick, B.G. Baldwin, and R.G. Gillespie. 2013. Non-congruent colonizations and diversification in a coevolving pollination mutualism on oceanic islands. Proceedings of the Royal Society B 280: 20130361

Hocking, B. 1968. Insect-flower associations in the high Arctic with special reference to nectar. Oikos 19:359-388.

Inouye, D. W., and G. H. Pyke. 1988. Pollination biology in the snowy mountains of Australia - comparisons with Montane Colorado, USA. Australian Journal of Ecology 13: 191-210.

Johnson, W. S. \& Ruben, P. 1988 Cleaning behavior of Bodianus rufus, Thalassoma bifasciatum, Gobiosoma evelynae, and Periclimenes pedersoni along a depth gradient at Salt River Submarine Canyon, St. Croix. Environmental Biology of Fishes 23: 225-232. 
Kaiser-Bunbury, C. N., S. Muff, J. J. Memmott, C. B. Mueller, and A. Caflisch. 2010. The robustness of pollination networks to the loss of species and interactions: a quantitative approach incorporating pollinator behaviour. Ecology Letters 13: 442-452.

Kawakita, A., and M. Kato. 2006. Assessment of the diversity and species specificity of the mutualistic association between Epicephala moths and Glochidion trees. Molecular Ecology 15: $3567-3581$.

Kevan, P. G. 1970. High Arctic insect-flower visitor relations: the inter-relationships of arthropods and flowers at Lake Hazen, Ellesmere Island, Northwest Territories, Canada. PhD Thesis. University of Alberta, Canada.

Machado, C. A., N. Robbins, M. T. P. Gilbert, and E. A. Herre. 2005. Critical review of host specificity and its coevolutionary implications in the fig/fig-wasp mutualism. Proceedings of the National Academy of Sciences of the USA 102: 6558-6565.

Medan, D, N. H. Montaldo, M. Devoto, A. Mantese, V. Vasellati, and N. H. Bartoloni. 2002. Plant-pollinator relationships at two altitudes in the Andes of Mendoza, Argentina. Arctic, Antarctic and Alpine Research 34: 233-241.

Memmott, J. 1999. The structure of a plant-pollinator food web. Ecology Letters 2: 276-280.

Ollerton, J. 2006. "Biological Barter": patterns of specialization compared across different mutualisms. Pages 411-435 in N. M. Waser and J. Ollerton (eds). Plant-pollinator interactions: from specialization to generalization. University of Chicago Press, Chicago.

Passos, L., and P.S. Oliveira. 2003. Interactions between ants, fruits and seeds in a Restinga Forest in South-Eastern Brazil. Journal of Tropical Ecology 19: 261-270.

Pires, M. M., and P. R. Guimarães Jr. 2013. Interaction intimacy organizes networks of antagonistic interactions in different ways. Journal of The Royal Society Interface, doi: 10.1098/rsif.2012.0649.

Pizo, M. A., and P. S. Oliveira. 2000. The use of fruits and seeds by ants in the Atlantic Forest of Southeast Brazil. Biotropica 32: 851-861. 
Ricciardi, F., Massimo B., and J. Ollerton. 2010. Assemblage and interaction structure of the anemonefish-anemone mutualism across the Manado Region of Sulawesi, Indonesia. Environmental Biology of Fishes 87: 333-347.

Rico-Gray, V. 1993. Use of plant-derived food resources by ants in the dry tropical lowlands of Coastal Veracruz, Mexico. Biotropica 25: 301-315.

Rico-Gray, V., M. Palacios-Rios, J. G. Garcia-Franco, and W. P. Mackay. 1998. Richness and seasonal variation of ant-plant associations mediated by plant-derived food resources in the semiarid Zapotitlán Valley, México. American Midland Naturalist 140: 21-26.

Sazima, C. 2002. Atividade de limpeza de duas espécies sintópicas de peixes limpadores e diversidade de seus clientes em Abrolhos, Bahia. MSc. Thesis, Universidade Estadual Paulista, UNESP, Rio Claro, Brazil.

Stein, M. 1987. Large sample properties of simulations using Latin Hypercube Sampling. Technometrics 29: 143-151.

Vázquez, D. P, and D. Simberloff. 2002. Ecological specialization and susceptibility to disturbance: conjectures and refutations. The American Naturalist 159: 606-623.

Vázquez, D. P, and D Simberloff. 2003. Changes in interaction biodiversity induced by an introduced ungulate. Ecology Letters 6: 1077-1083.

Wicksten, M. K. 1998. Behaviour of cleaners and their client fishes at Bonaire, Netherlands Antilles. Journal of Natural History 32, 13-30. 
Table A1. Parameter combinations used for sensitivity analysis.

\begin{tabular}{|c|c|c|c|}
\hline Sample & $\begin{array}{c}\text { Initial trait } \\
\text { variance }\left(\sigma_{A}=\sigma_{B}\right)\end{array}$ & $\begin{array}{c}\text { Strength of } \\
\text { stabilizing selection }(\gamma)\end{array}$ & $\begin{array}{c}\text { Strength of } \\
\text { intraspecific } \\
\text { competition }(c)\end{array}$ \\
\hline s1 & 0.58 & 0.00 & 0.74 \\
\hline s2 & 0.76 & 0.08 & 0.56 \\
\hline s3 & 0.61 & 0.10 & 0.62 \\
\hline s4 & 0.73 & 0.15 & 0.54 \\
\hline s5 & 0.05 & 0.24 & 0.39 \\
\hline s6 & 0.19 & 0.28 & 0.97 \\
\hline s7 & 0.01 & 0.31 & 0.49 \\
\hline s8 & 0.32 & 0.36 & 0.21 \\
\hline s9 & 0.52 & 0.40 & 0.79 \\
\hline s10 & 0.30 & 0.46 & 0.88 \\
\hline s11 & 0.92 & 0.55 & 0.07 \\
\hline s12 & 0.25 & 0.56 & 0.02 \\
\hline s13 & 0.66 & 0.62 & 0.16 \\
\hline s14 & 0.41 & 0.69 & 0.11 \\
\hline s15 & 0.48 & 0.74 & 0.30 \\
\hline s16 & 0.87 & 0.79 & 0.26 \\
\hline s17 & 0.38 & 0.81 & 0.80 \\
\hline s18 & 0.14 & 0.88 & 0.94 \\
\hline s19 & 0.81 & 0.91 & 0.44 \\
\hline $\mathbf{s 2 0}$ & 0.97 & 0.98 & 0.70 \\
\hline
\end{tabular}


Table A2. Information on the datasets used to describe species richness in natural mutualistic assemblages.

\begin{tabular}{|c|c|c|c|}
\hline $\begin{array}{l}\text { Interaction } \\
\text { Intimacy }\end{array}$ & Type of Mutualism & $\begin{array}{c}\text { Number of } \\
\text { datasets }\end{array}$ & References \\
\hline High & $\begin{array}{c}\text { Obligate mutualism } \\
\text { between anemone fishes and their } \\
\text { host sea anemones }\end{array}$ & 17 & $\begin{array}{l}\text { Frisch and Hobbs } 2009 \text {; } \\
\text { Ricciardi et al. } 2010\end{array}$ \\
\hline High & $\begin{array}{l}\text { Mutualisms between } \\
\text { specialized ants and myrmecophyte } \\
\text { plants hosting their nests }\end{array}$ & 5 & $\begin{array}{l}\text { Davidson et al. 1989; Davidson } \\
\text { and Fisher 1991; Fonseca and } \\
\text { Ganade 1996; Guimarães et al. } \\
2007\end{array}$ \\
\hline High & $\begin{array}{l}\text { Highly specialized, obligate } \\
\text { mutualisms between plants and } \\
\text { pollinating seed parasites }\end{array}$ & 13 & $\begin{array}{l}\text { Machado et al. 2005; Kawakita } \\
\text { and Kato 2006; Azuma et al. } \\
\text { 2010; Hembry 2012; Hembry et } \\
\text { al. } 2013\end{array}$ \\
\hline Low & $\begin{array}{l}\text { Cleaning mutualisms involving } \\
\text { cleaner species (shrimps or fishes) } \\
\text { and their client species (fishes) }\end{array}$ & 3 & $\begin{array}{l}\text { Johnson and Ruben 1988, } \\
\text { Wicksten 1998; Sazima } 2002\end{array}$ \\
\hline Low & Ant-mediated seed dispersal & 2 & $\begin{array}{l}\text { Pizo and Oliveira 2000; Passos } \\
\text { and } \\
\text { Oliveira } 2003\end{array}$ \\
\hline Low & $\begin{array}{l}\text { Generalized ant-plant protection } \\
\text { mutualisms }\end{array}$ & 3 & $\begin{array}{l}\text { Rico-Gray 1993; Rico-Gray et } \\
\text { al. 1998; Diaz-Castelazo et al. } \\
2004\end{array}$ \\
\hline Low & $\begin{array}{l}\text { Mutualisms between animal } \\
\text { pollinators and flowering plants }\end{array}$ & 14 & $\begin{array}{l}\text { Hocking 1968; Kevan 1970; } \\
\text { Arroyo et al. 1982; Barrett and } \\
\text { Helenurm 1987; Inouye and } \\
\text { Pyke 1988; } \\
\text { Elberling and Olesen 1999; } \\
\text { Memmott 1999, Medan et al. } \\
\text { 2002; Vázquez and Simberloff } \\
\text { 2002, 2003; Kaiser-Bunbury et } \\
\text { al. } 2010\end{array}$ \\
\hline
\end{tabular}




\section{Figure Captions: Online Appendix A - Supporting Information}

Figure A1. The reproductive outcome of mutualistic interactions for individuals of species $A$, $P_{\text {mut }}\left(z_{A}\right)$, considering a fixed value of $z_{B}=1$ and different values of $\lambda$, the parameter describing the effect of the trait matching of mutualistic interactions on individual mating probabilities (see equation 4 in the main text).

Figure A2. Temporal variation in species richness $(S)$ according to the limiting parameter, 1, used in the phenotypic clustering criterion (PCC). $S$ is the sum of clades derived from species $A$ and $B$ emerging in simulations of adaptive diversification. Lines describe different values of $l$, which defines the phenotypic discontinuity determining species borders. Blue, $l=0.05$; red, $l=0.1$; green, $l=0.2$; black, $l=0.4$. Same parameters as those of Figure 1 (see main text) through 10,000 time steps.

Figure A3. Species delimitation according to the phenotypic clustering criterion (PCC). (A) Reproductive networks of parents (cold colors) and offspring (hot colors) for the last $(1,000$ th) generation with $l=0.2$. Each color represents a unique species derived from species $A$. Squares show males and circles indicate females. Each phenotypic cluster in the offspring if formed by sets of families descending from the same parental species. (B) Distribution of offspring individuals in clusters, here interpreted as species, for $l=0.1$ ( 8 species $)$ and $l=0.2$ (7 species). Species' colors are the same used in (A). (C) Frequency of individuals within each cluster for the $1,000^{\text {th }}$ generation and (D) Phenotypic trajectories for the trait $z$ through 1,000 generations. The last generation in the plot correspond to the data used in (A), (B), and (C).

Figure A4. Phenotypic trajectories under diverse mutualism attributes through 10,000 time steps. The values at the left of each panel indicate the number of mutualistic partners with which each individual of species $B$ interacted $\left(\omega_{B}\right)$. Other parameters are the same as in Figure 1 (see the main text). Temperature colors depict density of individuals, ranging from high (hot colors) to low (cold colors).

Figure A5. Temporal variation in number of species $(S)$ derived from species $A$ (black lines) and from species $B$ (red lines) under varying $\omega_{B}$. Numbers inside each panel indicate the number $\omega_{B}$ of mutualistic partners with which each species $B$ individual interacted. Other parameters are the same as in Figure 1 (see the main text).

Figure A6-A. Phenotypic trajectories plots for traits $z_{A}$ and $z_{B}$ under parameter combinations (s01-s05) obtained using Latin Hypercube sampling. See Table 1 for descriptions of the parameters and their values. The columns present phenotypic trajectories under each parameter combination and rows show results for three population sizes $\left(N_{A}=N_{B}=150,300\right.$, 600). Abscissae depict the number of time steps for which each simulation ran and follow the labels in the last row, ranging from 0 to 1000 . Colors represent density of individuals throughout the phenotypic space. $\omega_{B}=\lambda=1$.

Figure A6-B. Phenotypic trajectories plots for traits $\mathrm{z}_{\mathrm{A}}$ and $\mathrm{z}_{\mathrm{B}}$ under parameter combinations (s06-s10) obtained using Latin Hypercube sampling. See Table 1 for descriptions of the parameters and their values. The columns present phenotypic trajectories under each parameter combination and rows show results for three population sizes $\left(N_{A}=N_{B}=150,300\right.$, 600). Abscissae depict the number of time steps for which each simulation ran and follow the labels in the last row, ranging from 0 to 1000, except when indicated. Simulations with 
different duration ended due to species extinction. Colors represent density of individuals throughout the phenotypic space. $\omega_{B}=\lambda=1$.

Figure A6-C. Phenotypic trajectories plots for traits $\mathrm{z}_{\mathrm{A}}$ and $\mathrm{z}_{\mathrm{B}}$ under parameter combinations (s11-s15) obtained using Latin Hypercube sampling. See Table 1 for descriptions of the parameters and their values. The columns present phenotypic trajectories under each parameter combination and rows show results for three population sizes $\left(N_{A}=N_{B}=150,300\right.$, 600). Abscissae depict the number of time steps for which each simulation ran and follow the labels in the last row, ranging from 0 to 1000, except when indicated. Simulations with different duration ended due to species extinction. Colors represent density of individuals throughout the phenotypic space. $\omega_{B}=\lambda=1$.

Figure A6-D. Phenotypic trajectories plots for traits $\mathrm{z}_{\mathrm{A}}$ and $\mathrm{z}_{\mathrm{B}}$ under parameter combinations (s16-s20) obtained using Latin Hypercube sampling. See Table 1 for descriptions of the parameters and their values. The columns present phenotypic trajectories under each parameter combination and rows show results for three population sizes $\left(N_{A}=N_{B}=150,300\right.$, 600). Abscissae depict the number of time steps for which each simulation ran and follow the labels in the last row, ranging from 0 to 1000, except when indicated. Simulations with different duration ended due to species extinction. Colors represent density of individuals throughout the phenotypic space. $\omega_{B}=\lambda=1$.

Figure A7. Percentage of the species $A$ population remaining with no mutualistic partner within the first generation, under different numbers of mutualistic partners $\omega_{B}$. Other parameters as in table A1 (s1).

Figure A8. Individual-based simulations showing the effect of $\omega_{B}$ on adaptive diversification when $P_{m u t}$ is proportional to the mean trait complementarity of all interactions, instead of the sum of benefits obtained from each mutualistic partner (equation 4). Temperature colors represent density of individuals in the phenotypic space. Other parameters are the same as in table A1 (s1), with $N_{A}=N_{B}=600$. Abscissae values where $1 \leq \omega_{B} \leq 128$ are the same than those in the panel where $\omega_{B}=256$.

Figure A9. Adaptive diversification under increasing number of mutualistic partners per individual when both set of species have limits to the number of interaction events $\left(\omega_{A}=\omega_{B}\right)$. Interactions occur by rounds. The order of individuals of species $B$ choosing the partners is randomly assigned in each round. Each individuals interact $\omega_{K}$ times and than it is removed from the mutualistic pool. Colors represent individuals density. Other parameters are the same as in table A1 (s1), with $N_{A}=N_{B}=600$.

Figure A10. Asymptotic species richness for clades derived from species $A\left(S_{A}\right)$ and from species $B\left(S_{B}\right)$ when disruptive selection acts upon one of them $(A$ or $B)$ or both of them. Same parameters as in table A1 (s1), with $N_{A}=N_{B}=600$.

Figure A11. Phenotypic trajectories of traits $z_{A}$ and $z_{B}$ when only one of the species $(A$ or $B)$ is under disruptive selection. Same parameters as in table A1 (s1), with $N_{A}=N_{B}=600$.

Figure A12. Phenotypic trajectories of traits $z_{A}$ and $z_{B}$ when population sizes vary stochastically. $\omega_{B}$ is the number of different mutualistic partners of each individual of species B. $V$ is the parameter defining the degree of stochasticity to which the populations are subject. At any given generation, $V$ is randomly assigned to be positive or negative. After that, a 
percentage $V$ of the previous generation size is summed or subtracted to define the current generation size.

Figure A13. Species diversification when males are also under selective pressures arising from ecological interactions. The effects of $\omega_{B}$ and and $\lambda$ on species diversification are qualitatively the same than observed in Experiment 2. (A-C) The male mating pool is formed by a quarter of the original male subpopulation. (D-F) The male mating pool is formed by half of the original male subpopulation. The probability that a male remains in the population to form the mating pool is defined by the fitness components arising from ecological interactions (see the text for details). 


\section{Figure A1}
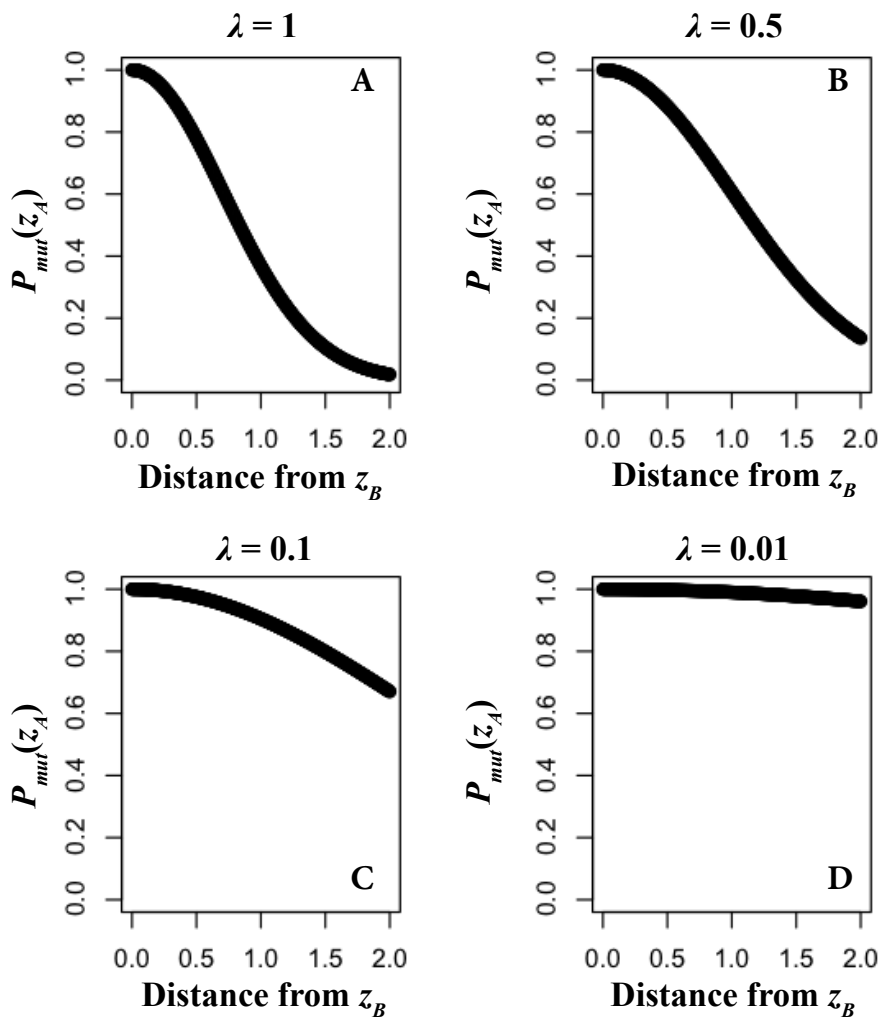
Figure A2

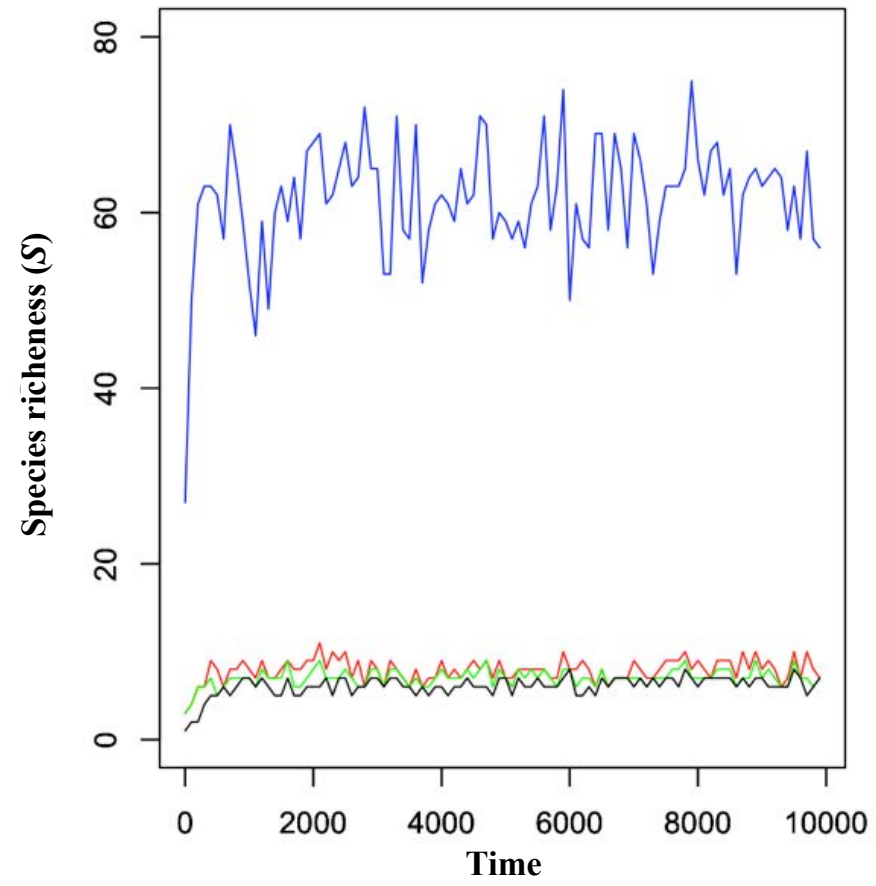


Figure A3

A

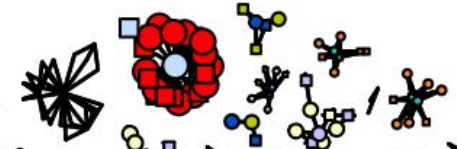
A 4 \%

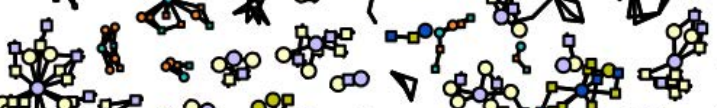
का

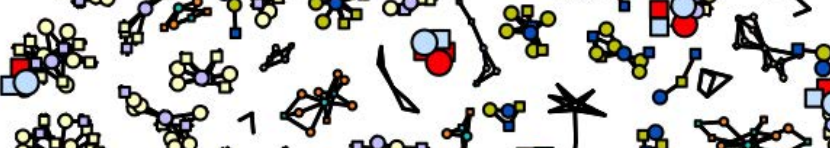
gaำ

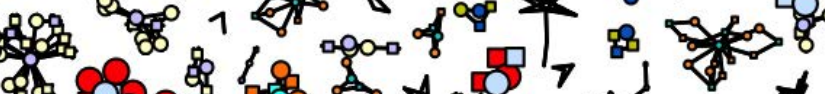

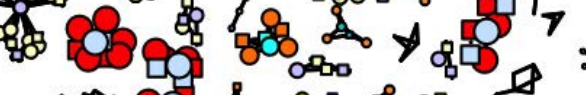
* ब0

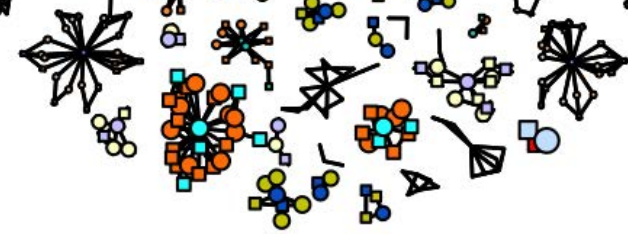

B $\begin{aligned} & l=0.1 \\ & l=0.2\end{aligned} \infty$
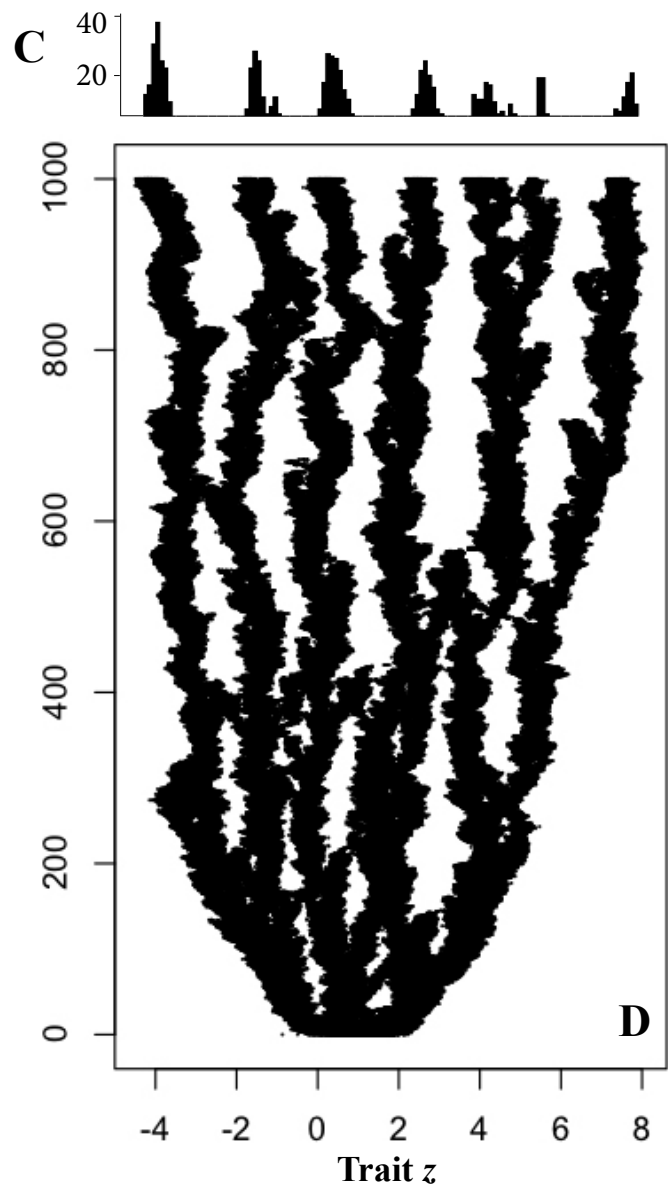


\section{Figure A4}
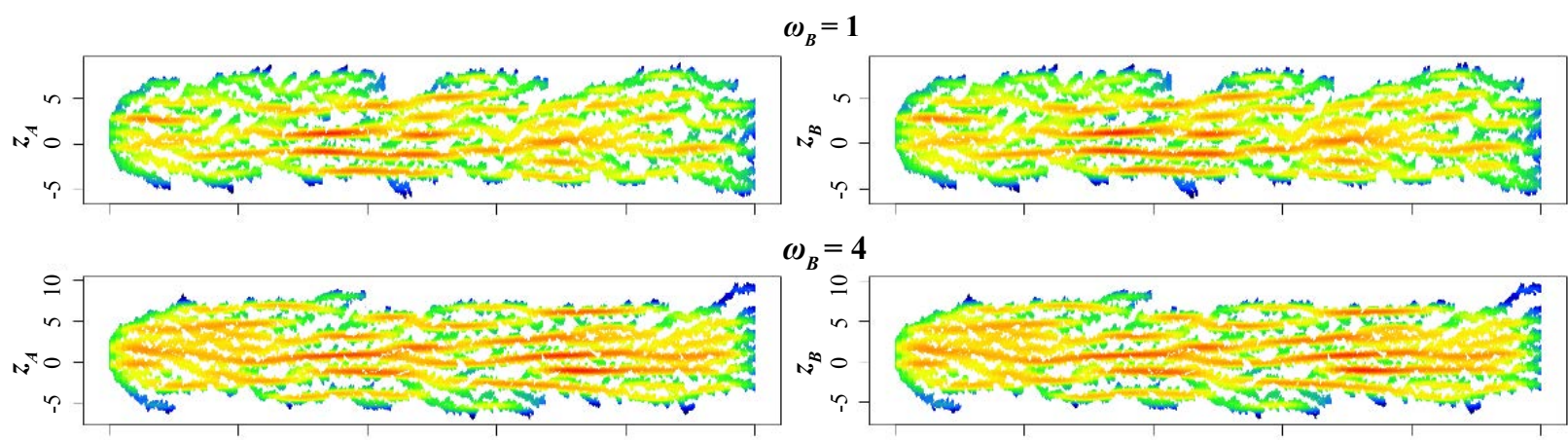

$\omega_{B}=4$
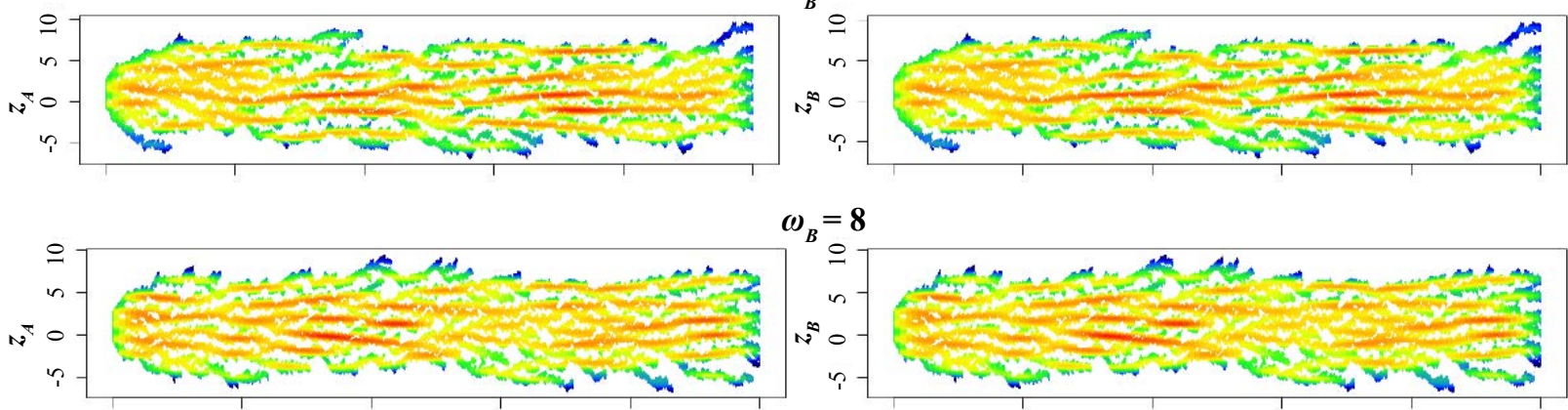

$\omega_{B}=8$
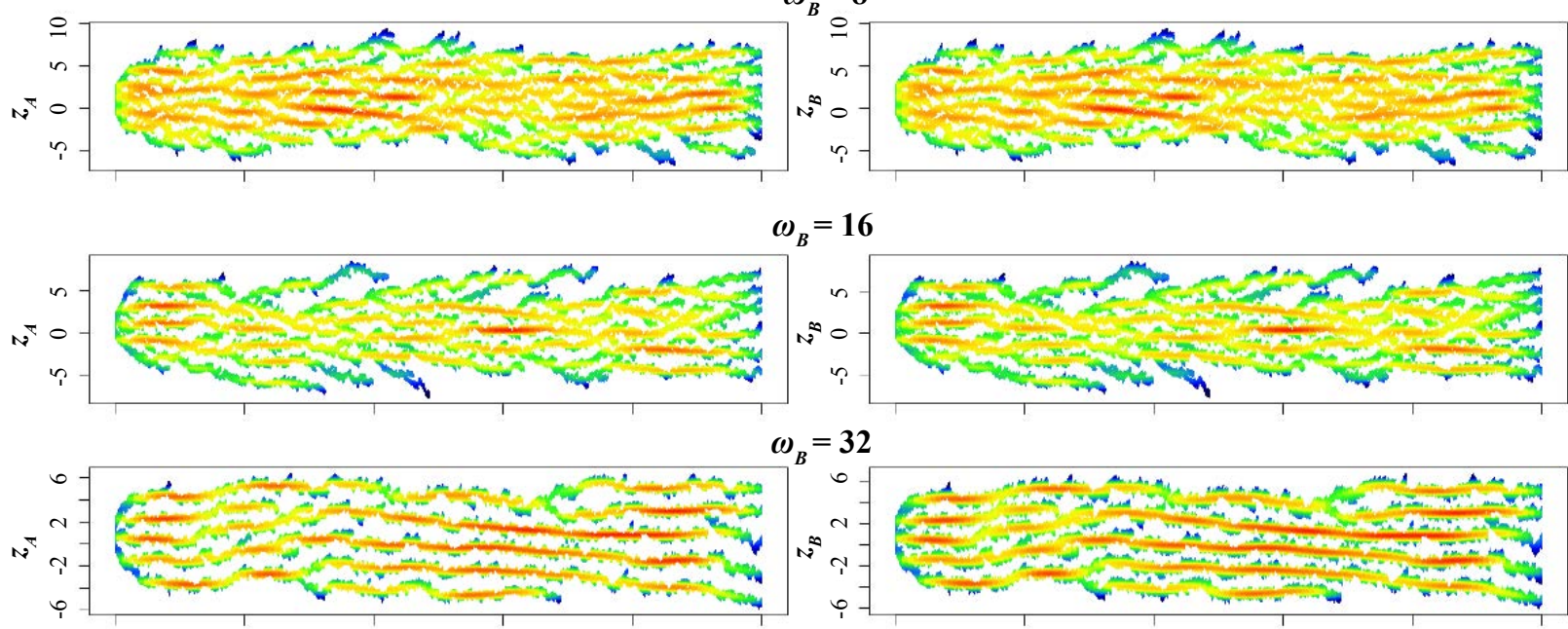

$$
\omega_{B}=64
$$
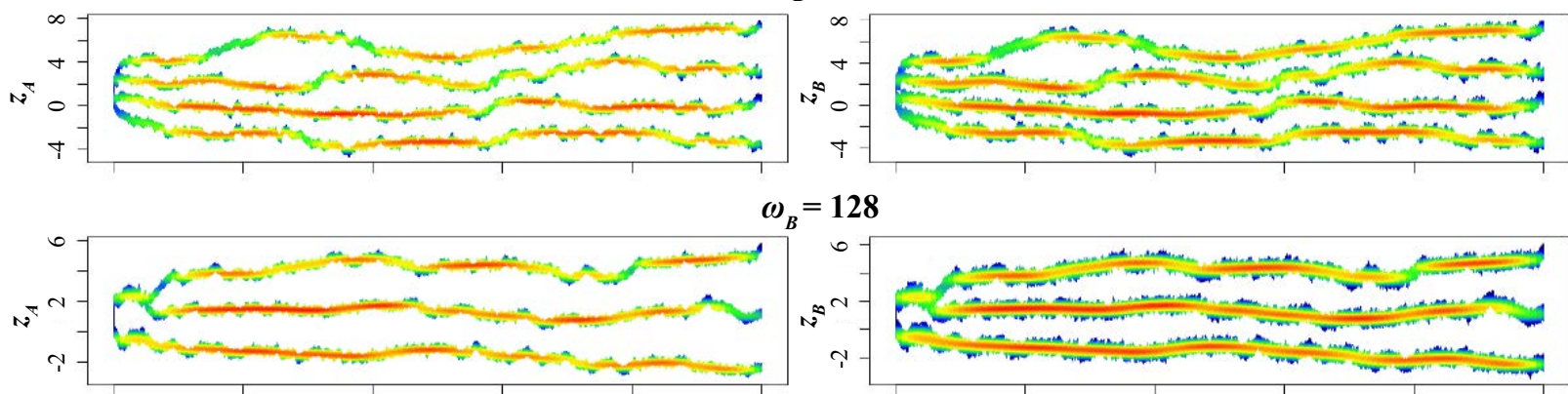

$\omega_{B}=128$

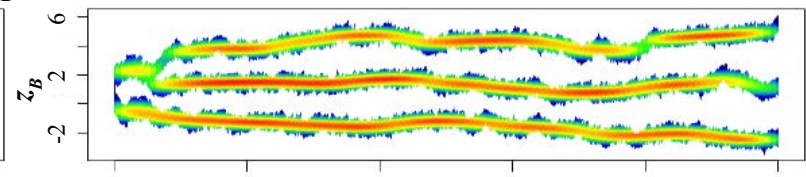

$$
\omega_{B}=256
$$
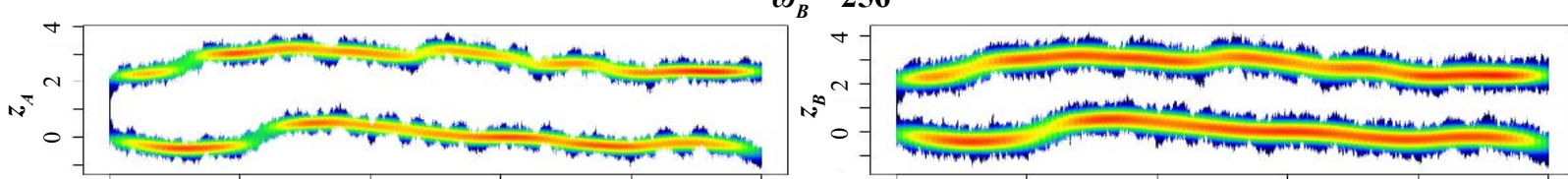

$$
\omega_{B}=512
$$

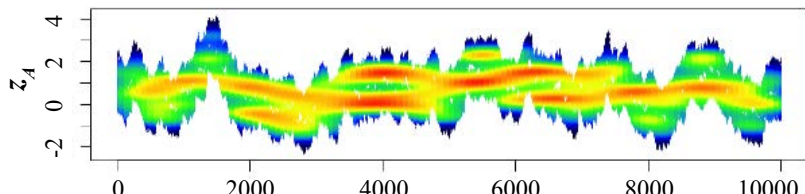

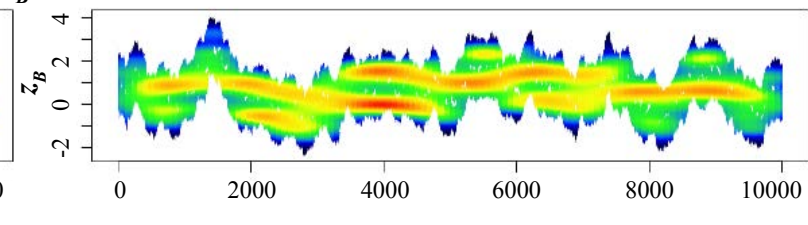




\section{Figure A5}
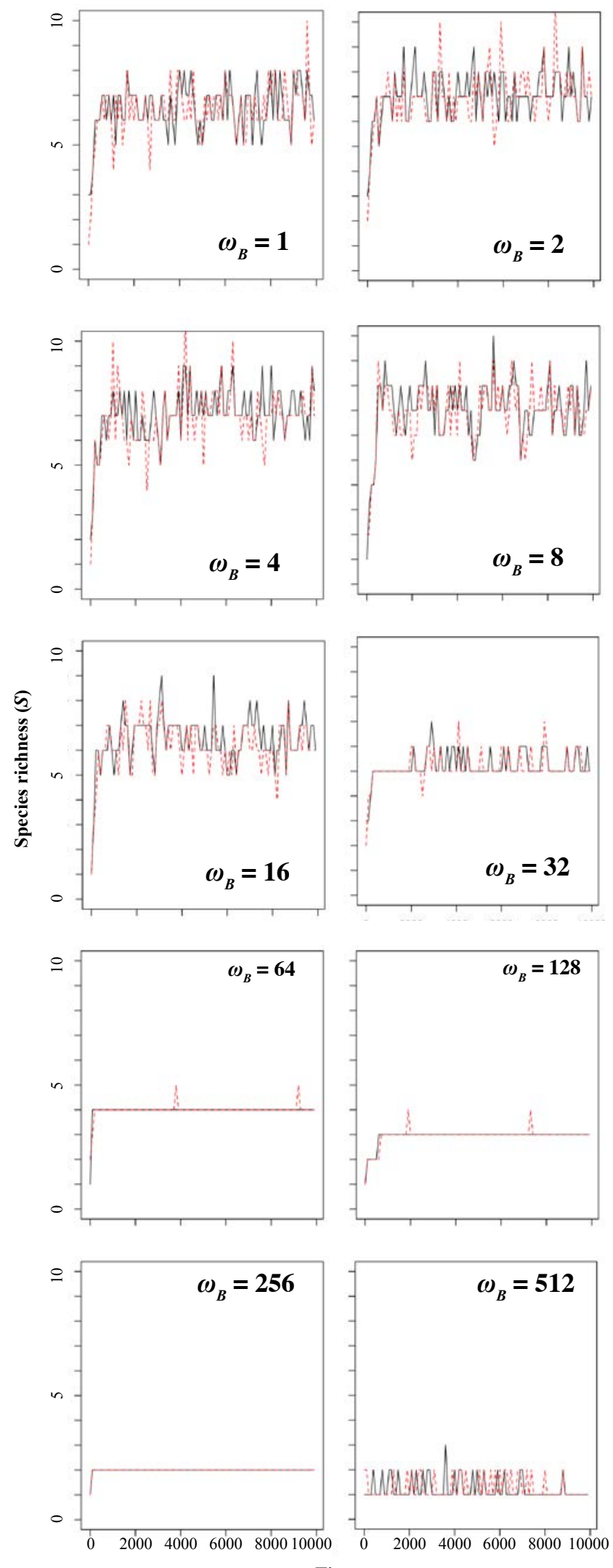

Time 
Figure A6-A

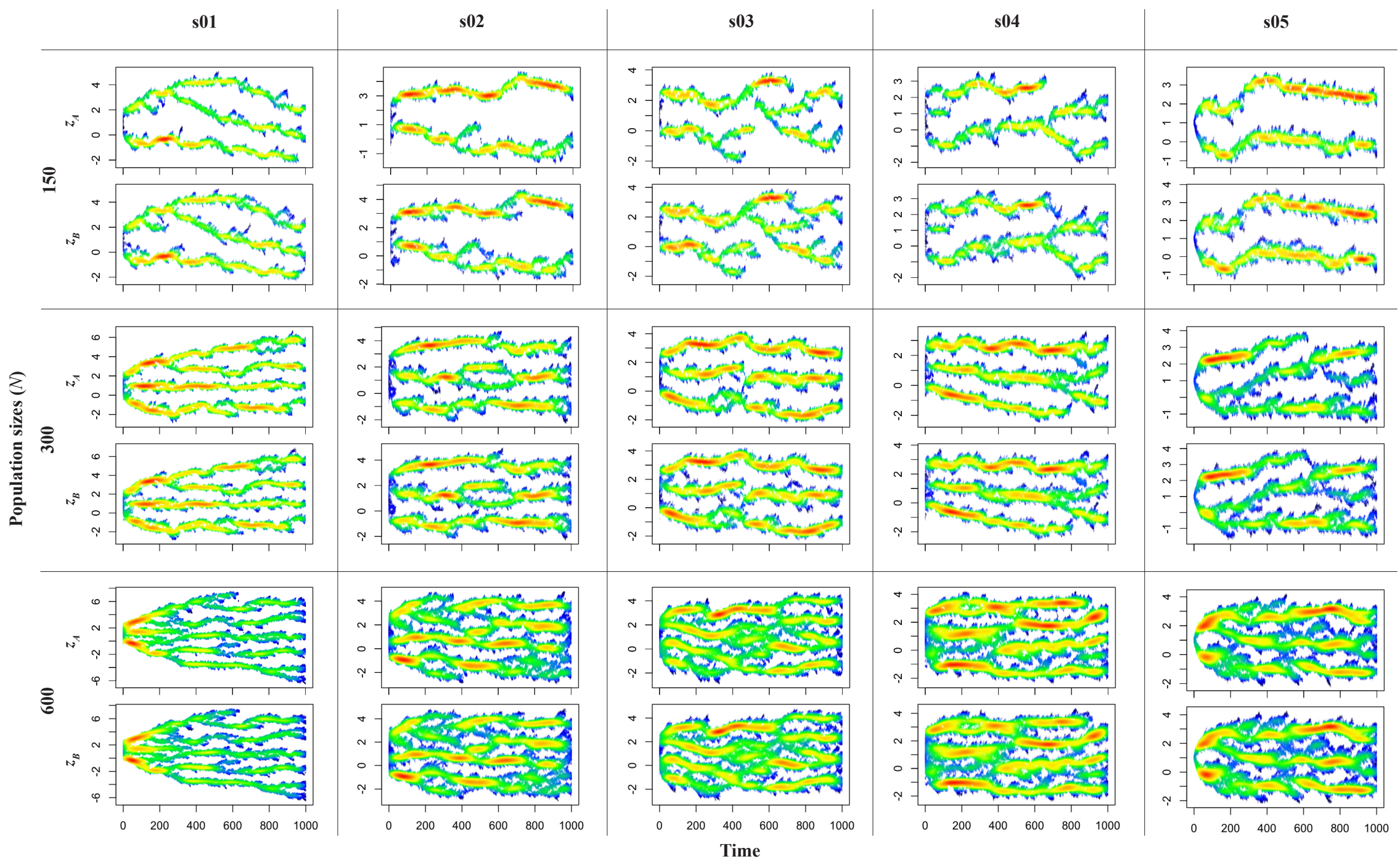


Figure A6-B

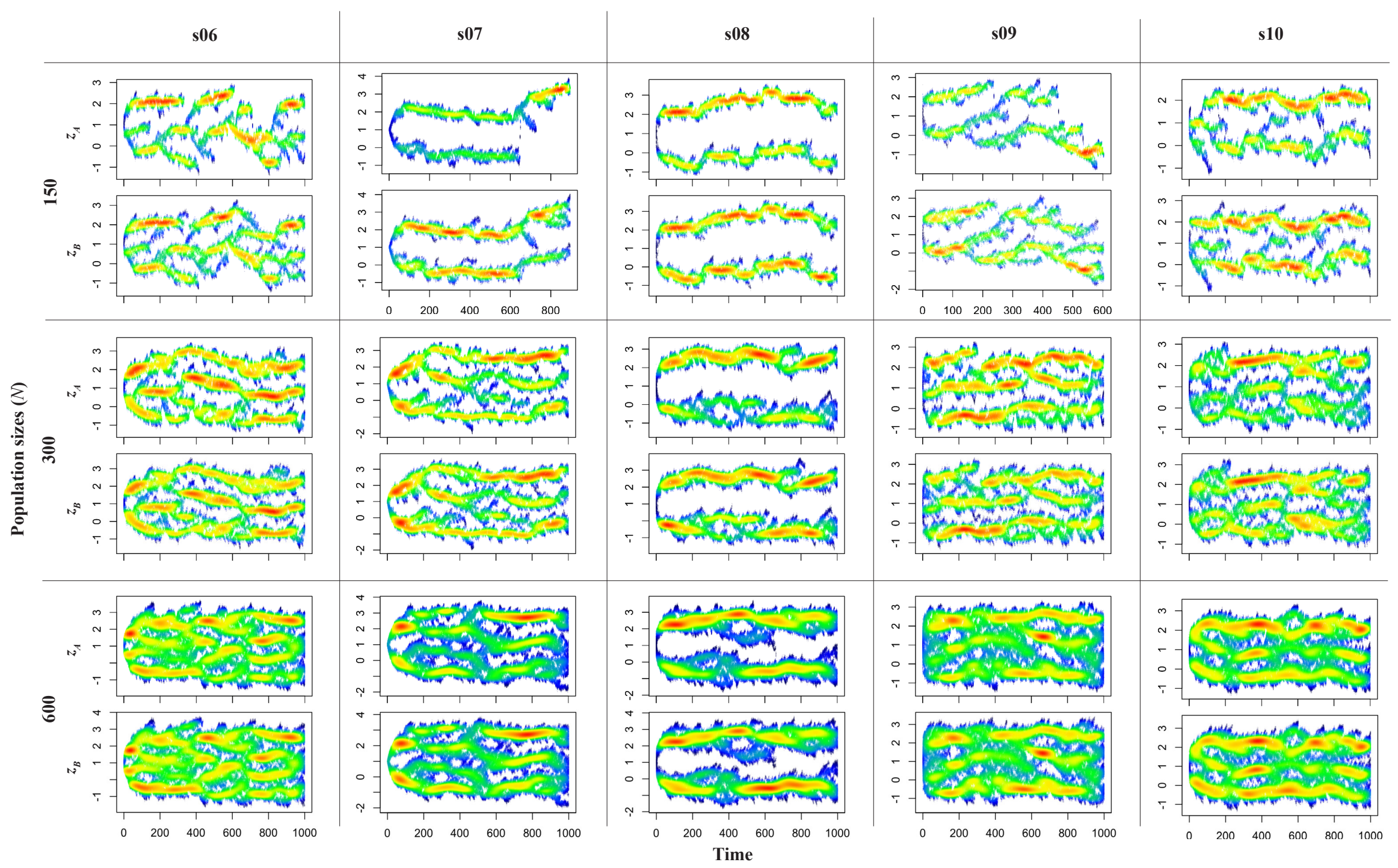


Figure A6-C

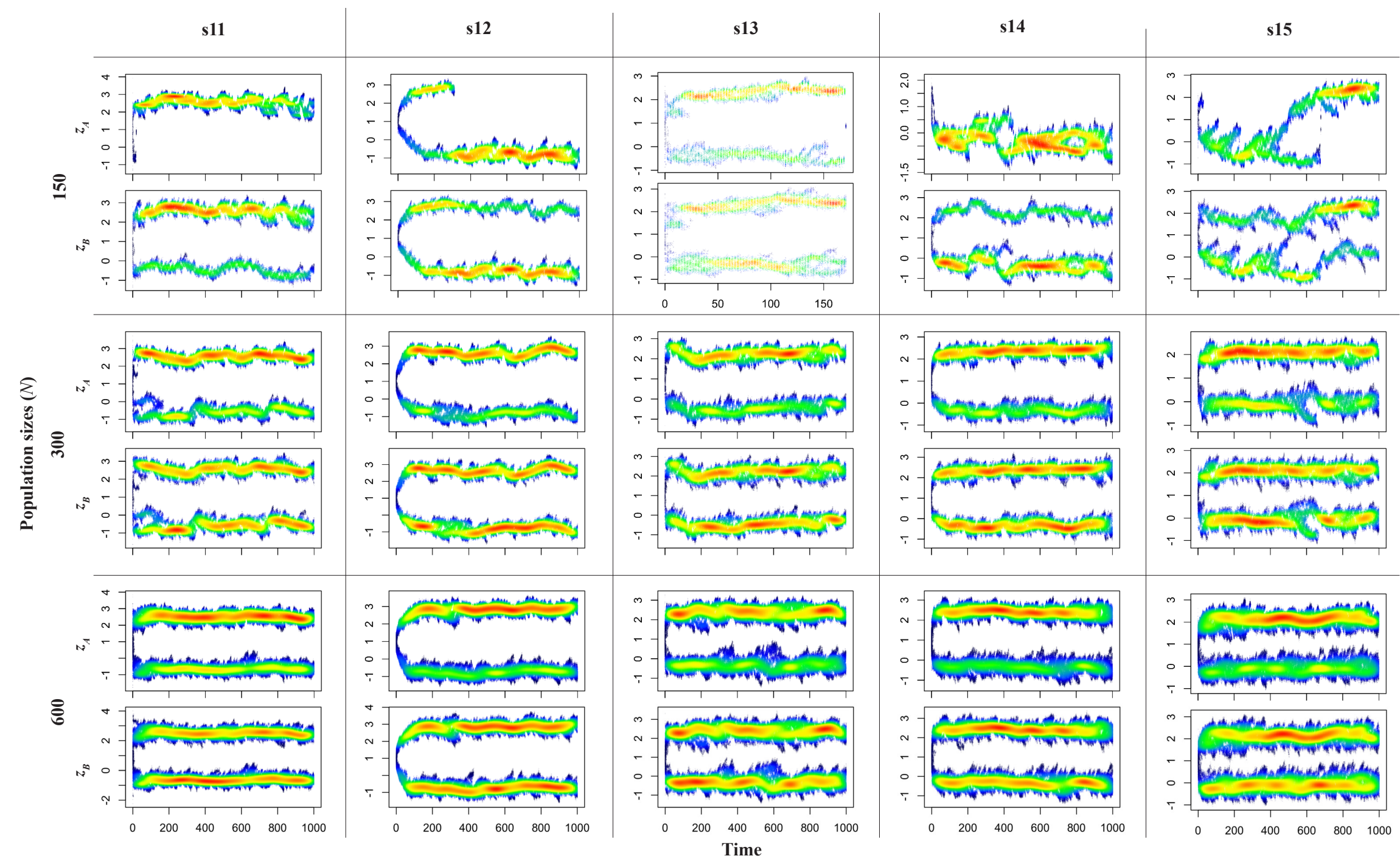


Figure A6-D

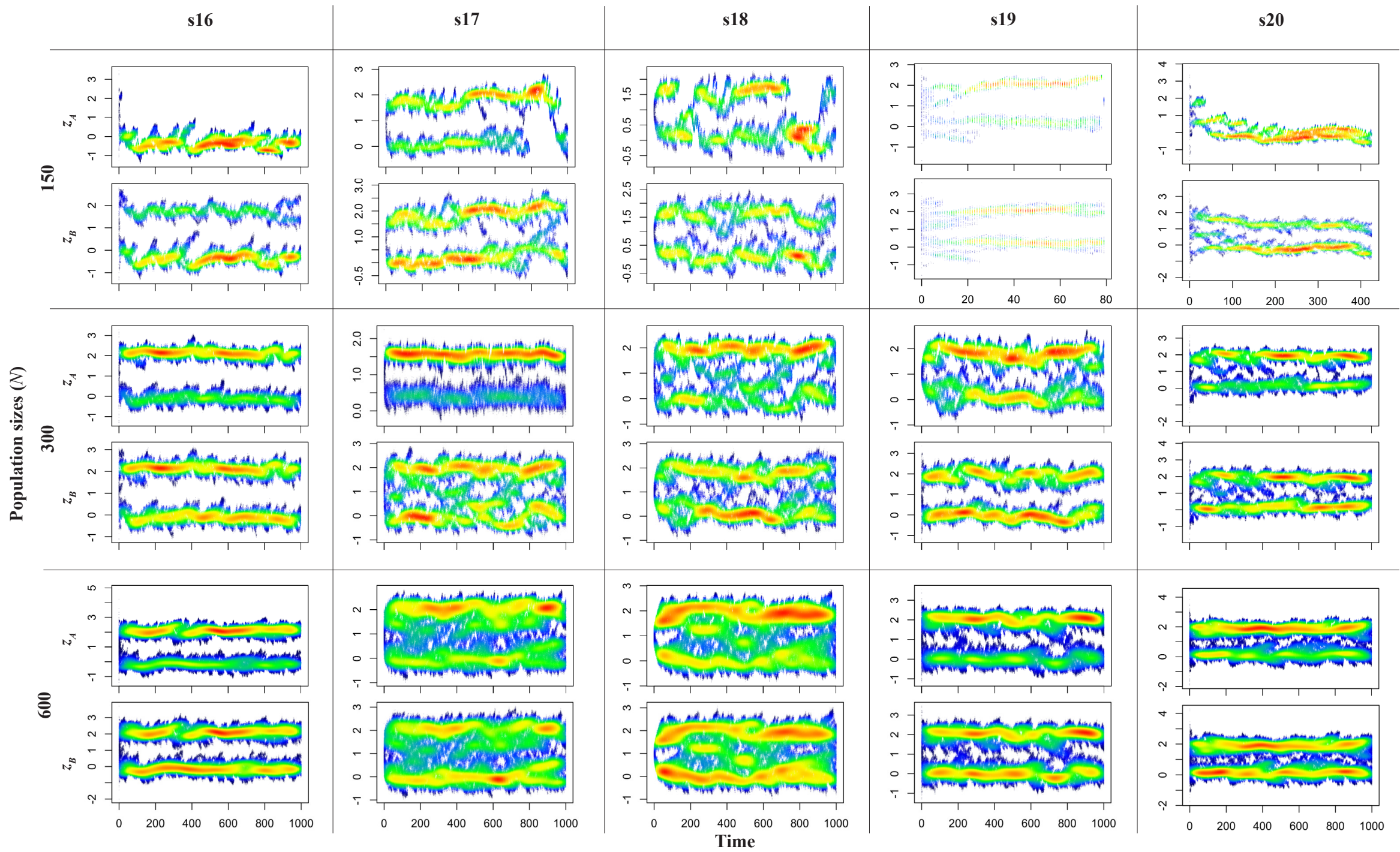


Figure A7

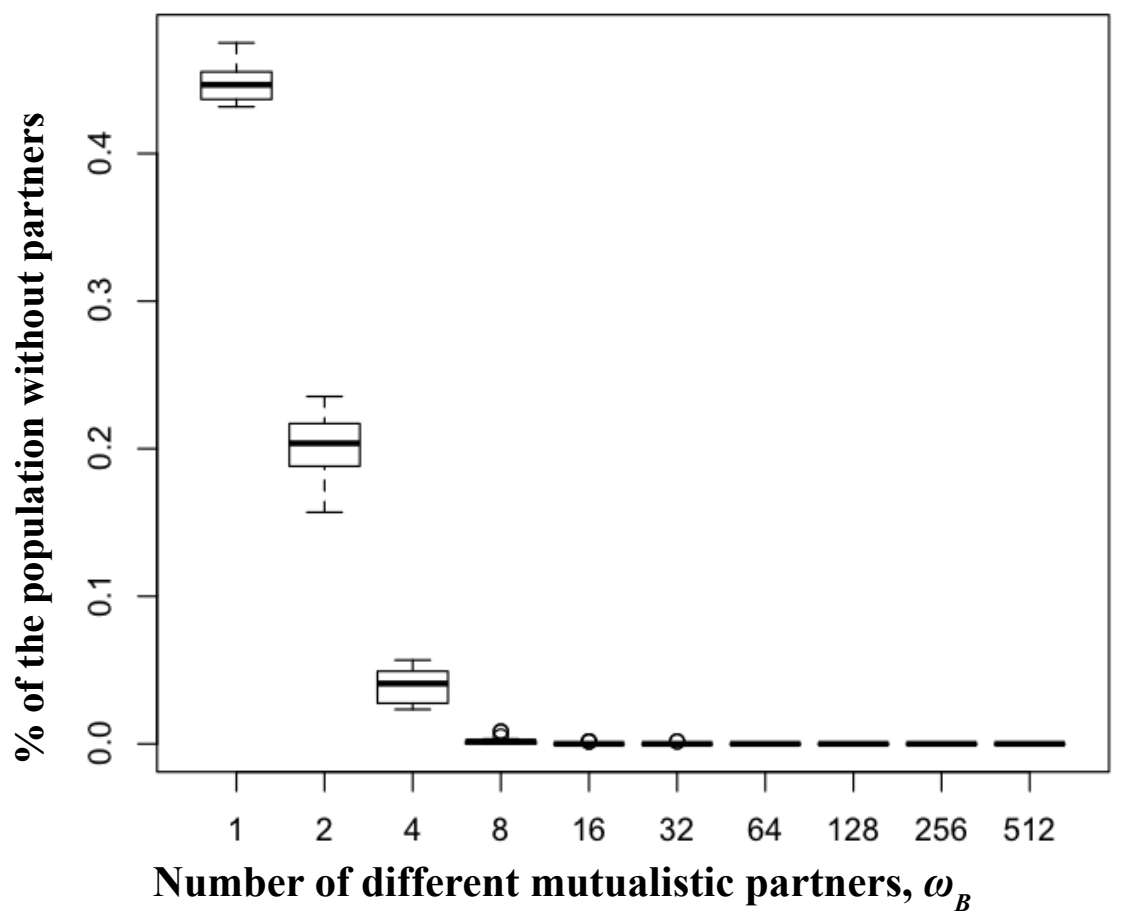


Figure A8

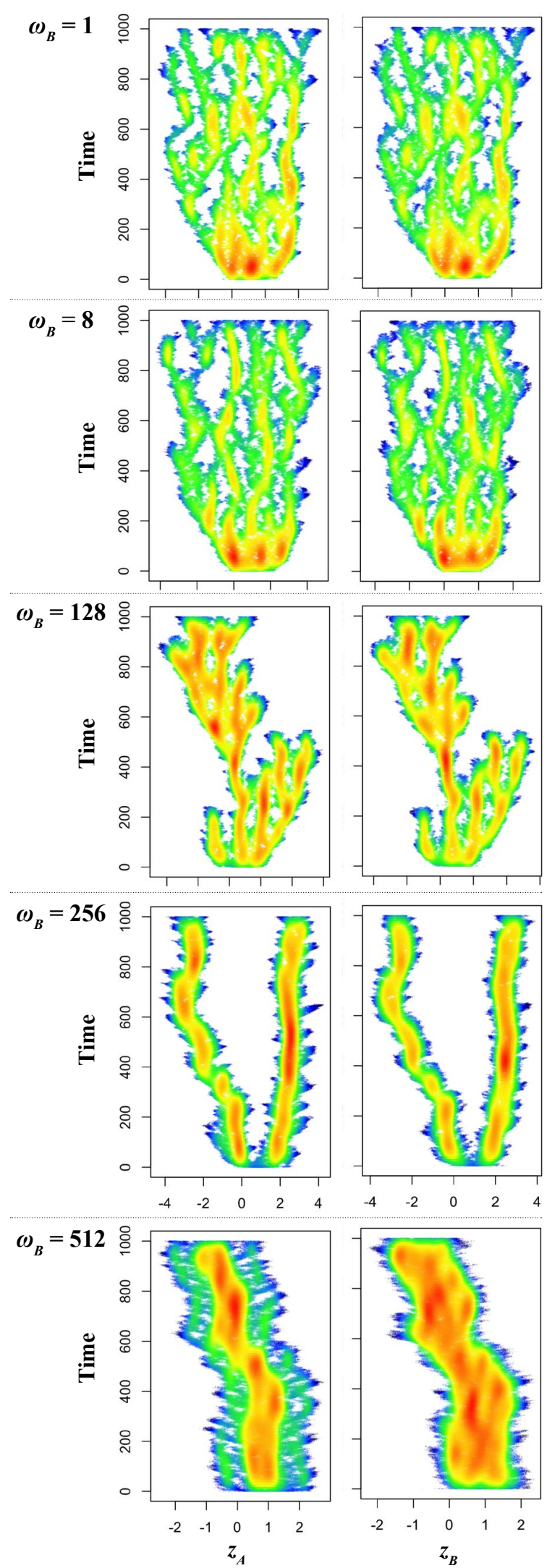


Figure A9
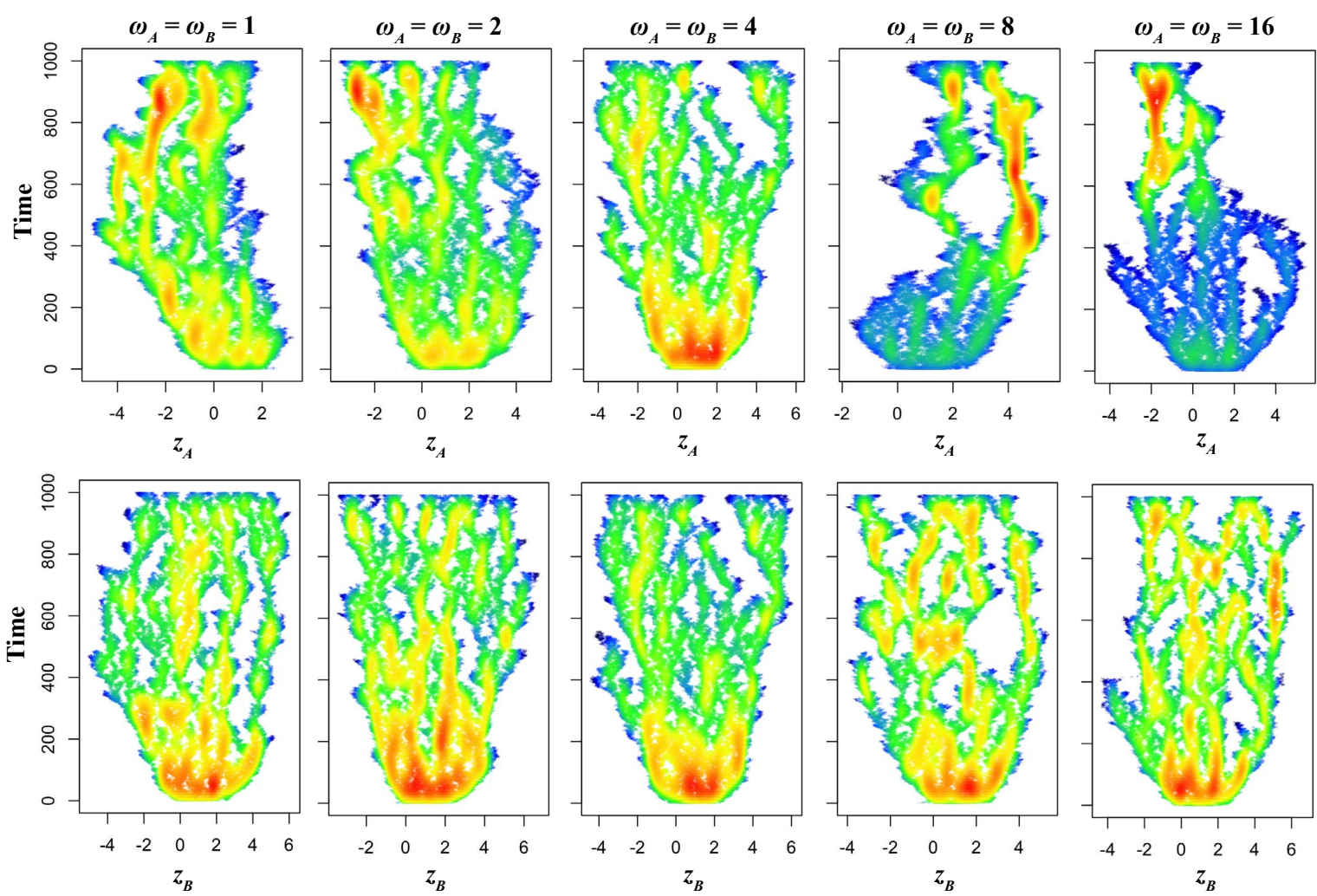
Figure A10

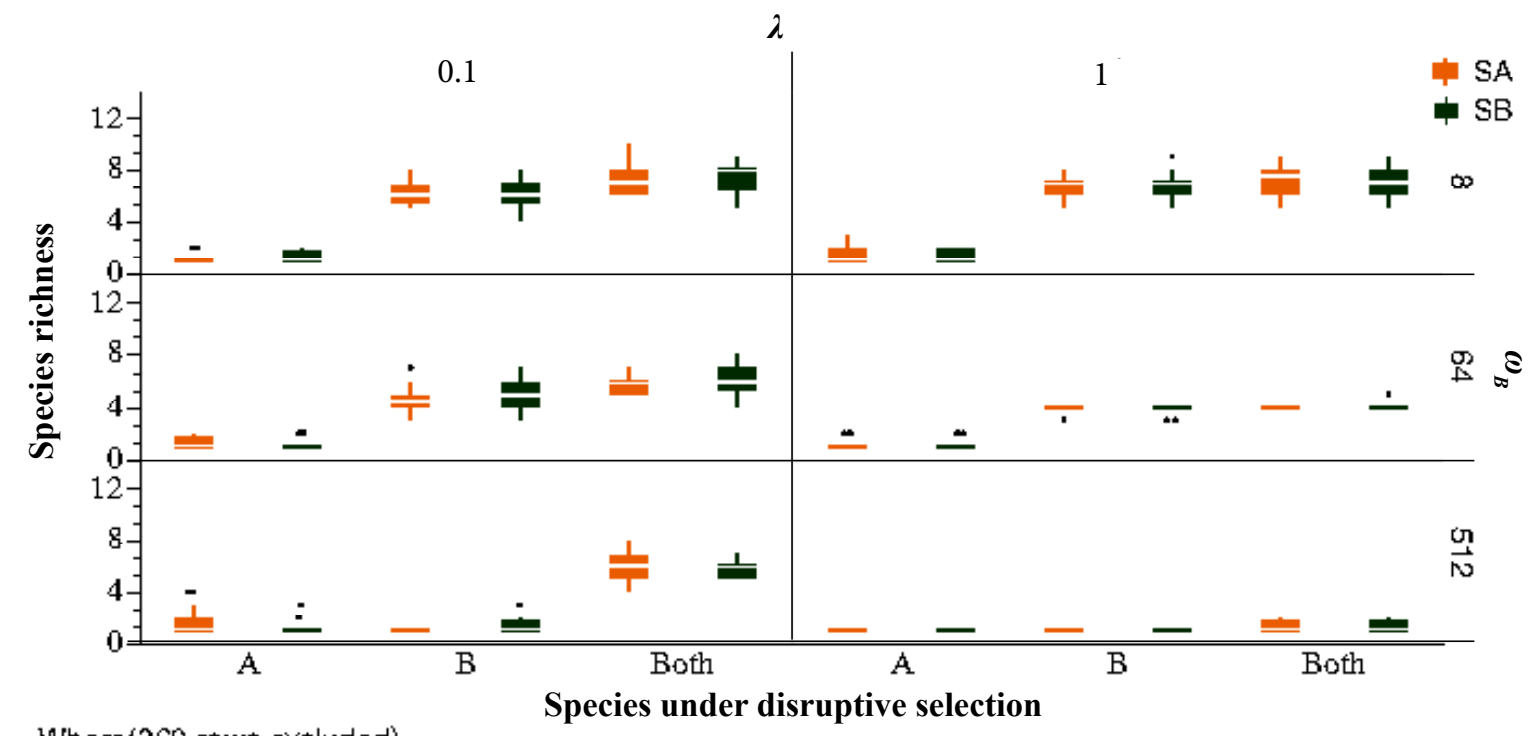


Figure A11

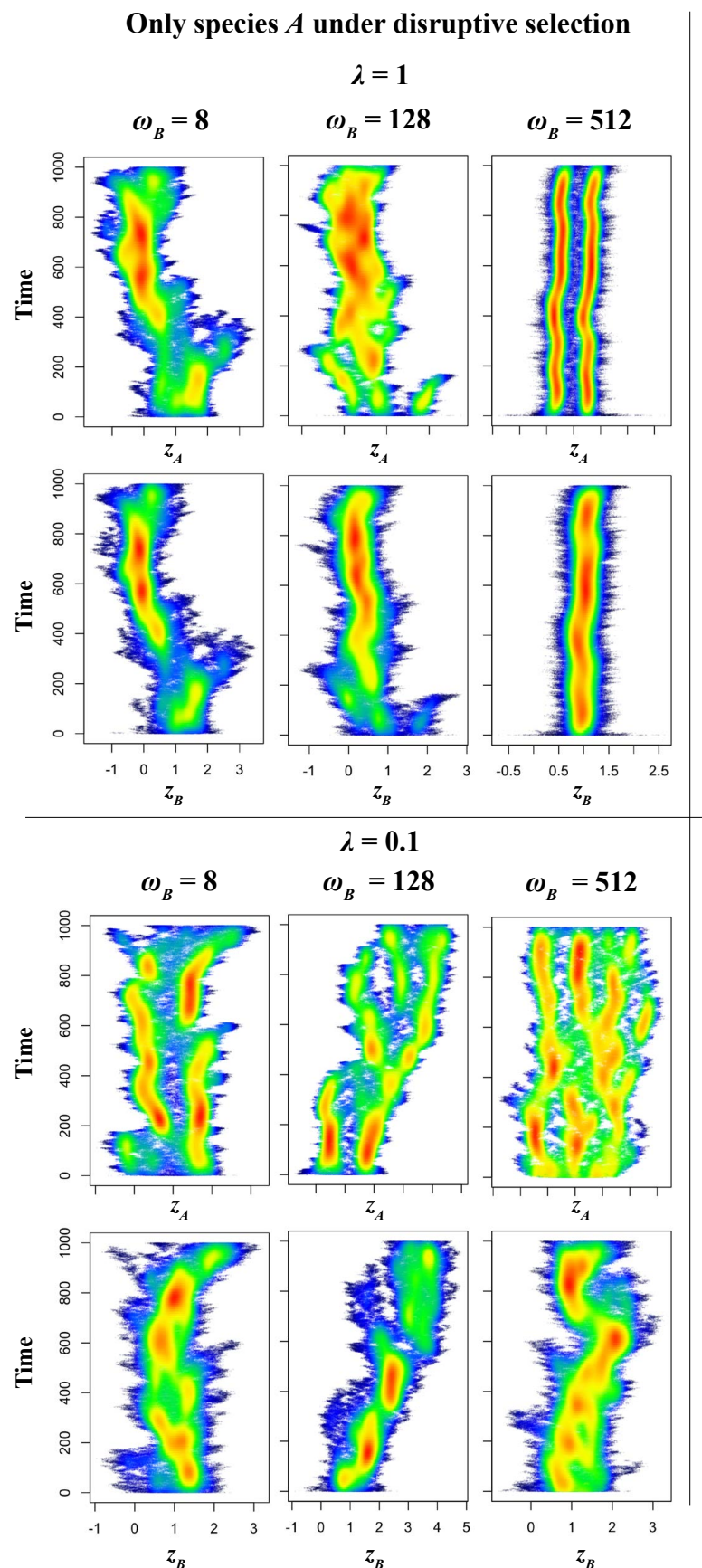

Only species $B$ under disruptive selection
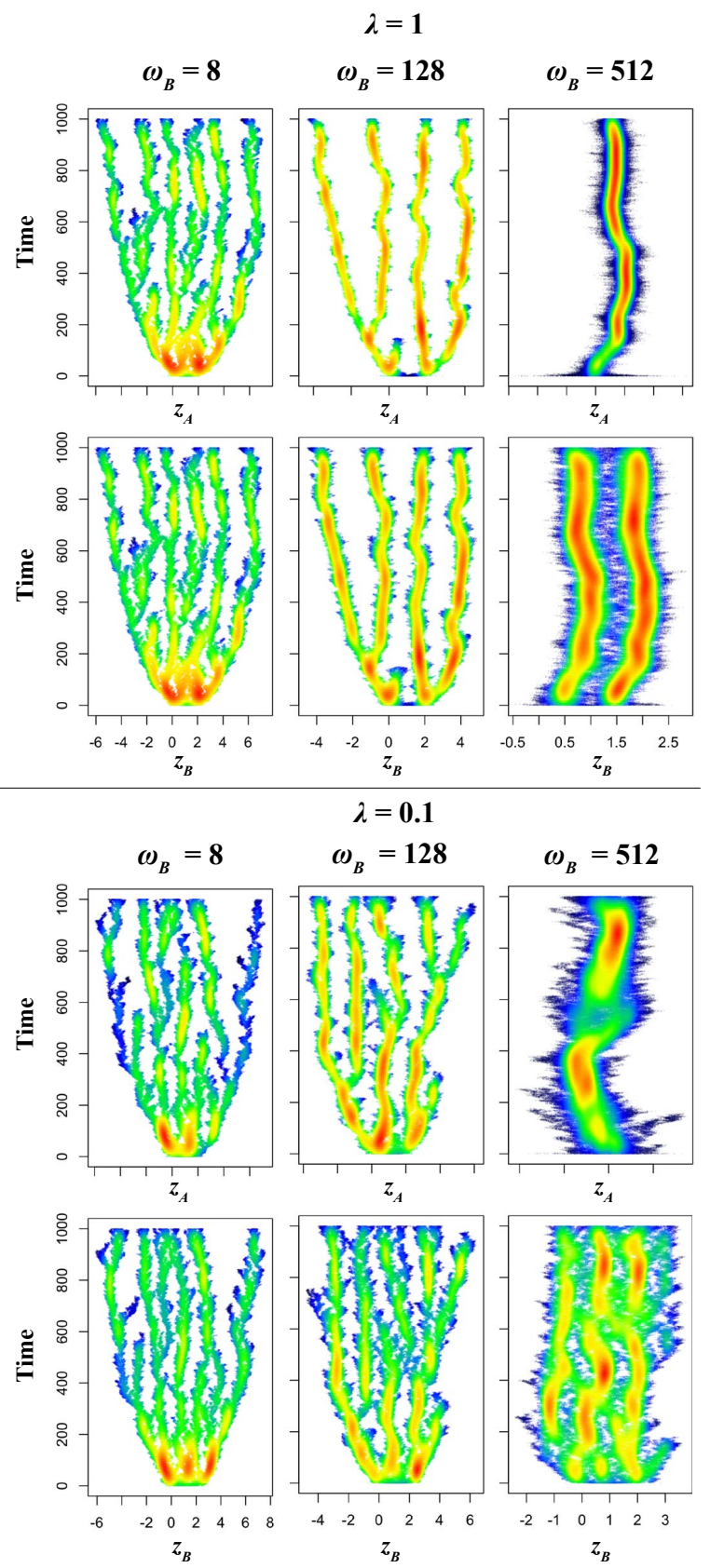
Figure A12
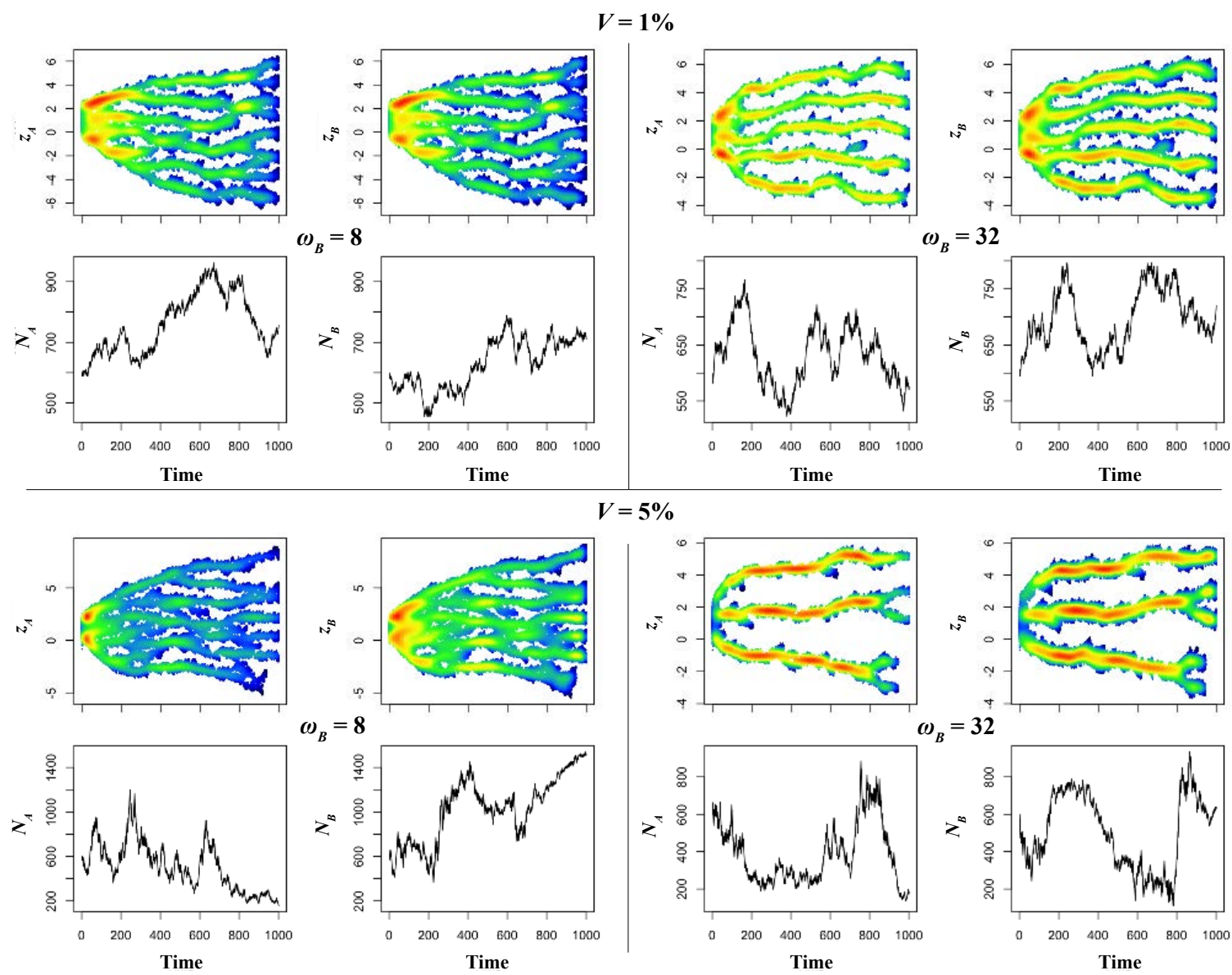
Figure A13

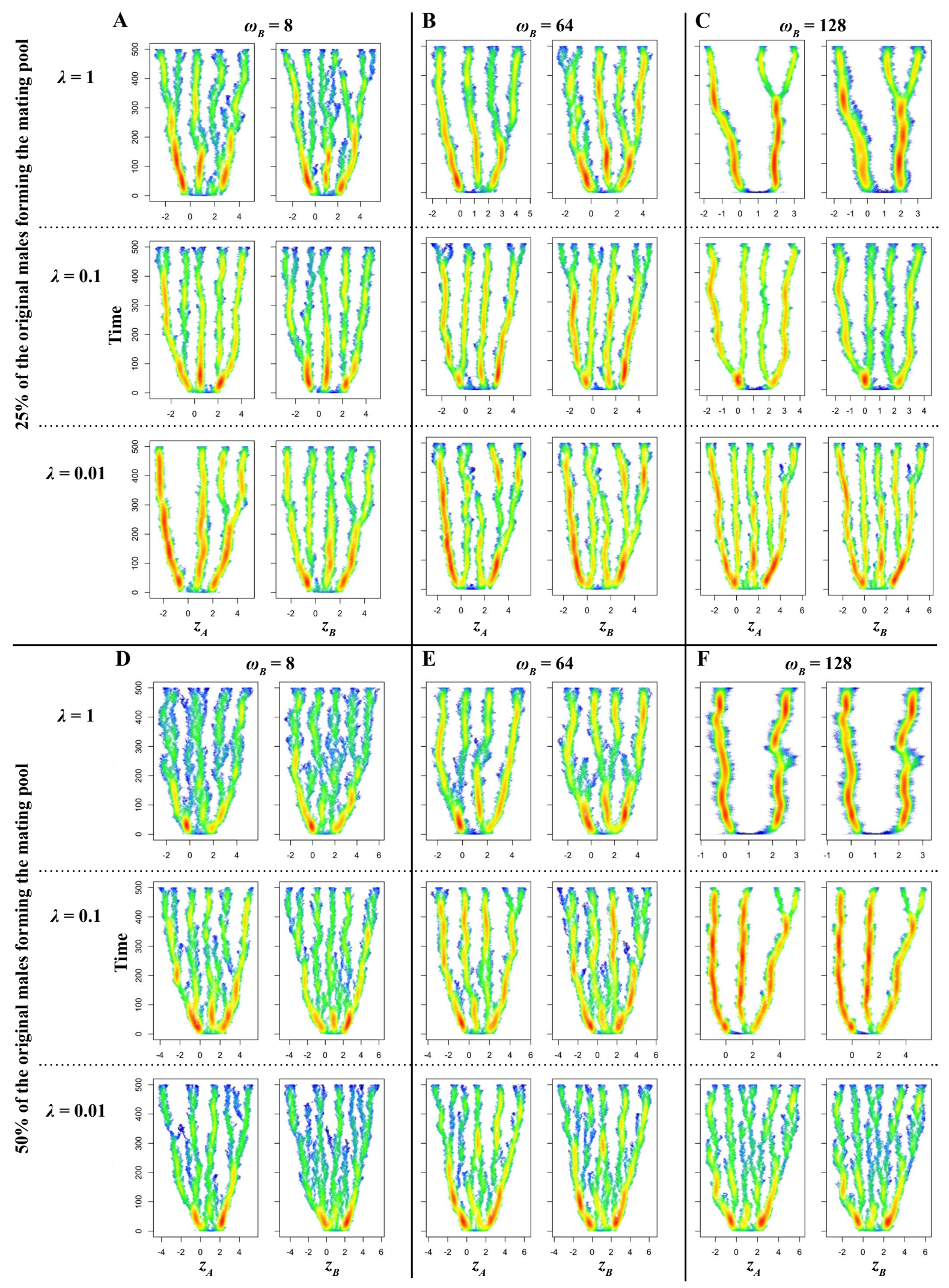




\title{
CAPÍtulo 3
}

\section{Does adaptive rewiring explain the structural variation of mutualistic networks?}

\author{
Rafael L. G. Raimundo ${ }^{1}$, Mathias M. Pires ${ }^{1}$, Vinicius A. G. Bastazini ${ }^{2}$, \\ Paulo R. Guimarães $\mathrm{Jr}^{1 *}$
}
${ }^{1}$ Departamento de Ecologia, Instituto de Biociências, Universidade de São Paulo, Rua do Matão, Travessa 14, no. 321, 05508-900, São Paulo, SP, Brazil.
${ }^{2}$ PPG - Ecologia, Instituto de Biociências, Universidade Federal do Rio Grande do Sul, Porto Alegre, RS, Brazil.
* Corresponding author.

Running title: Adaptive rewiring of mutualistic networks

Keywords: adaptive networks, community stability, modularity, nestedness. 


\begin{abstract}
Recent theoretical work suggests that adaptive rewiring, i.e., interaction switching that maximizes fitness, may shape the structural and dynamical properties of mutualistic networks. We tested this hypothesis using an adaptive network model and data from 44 empirical mutualistic assemblages. In our simulations, adaptive rewiring increased nestedness and decreased modularity regardless of network size. However, destabilizing effects were higher in species-rich networks. In low-intimacy mutualisms, such as interactions between plants and pollinators, the networks emerging from adaptive rewiring fit empirical nestedness and modularity better than the initial, neutral networks. By contrast, model networks failed to reproduce the empirical properties of high-intimacy networks, such as mutualisms between anemone fishes and sea anemones. Assumptions of different interspecific competition regimes among mutualists did not affect the emerging structural and stability properties but led to very distinct rewiring dynamics. Competition for mutualistic partners leads to neverending adaptive rewiring of pair-wise interactions, even after network structure and stability reach asymptotic levels. Competition for mutualists, therefore, may provide a potential mechanism for the observed high rates of interaction turnover within assemblages characterized by stable structural patterns at the network level. Our results support a role of natural selection of ecological interactions in shaping structural properties of low-intimacy mutualisms, especially under low to intermediate species richnesses, in which destabilizing effects of emerging nestedness would be less severe. However, adaptive rewiring cannot be taken as a general mechanism accounting for properties of all types of mutualistic networks. Other processes, such as diversifying coevolution, must be invoked to explain the structure and function of the high-intimacy mutualistic networks formed by a small number of reciprocally specialized species.
\end{abstract}




\section{INTRODUCTION}

Elucidating the relationship between patterns at the community level and mechanisms operating at different scales is a major challenge for ecologists (Levin 1992). The use of networks to represent species interactions has recently allowed quantitative comparisons of community organization, unraveling a diversity of architectural patterns across terrestrial and marine ecosystems (Bascompte \& Jordano 2007; Olesen et al. 2007; Ricciardi et al. 2010). Deepening our current understanding of the ecological and evolutionary processes that shape the structure and function of ecological networks (see Vázquez et al. 2009; Bascompte \& Jordano 2014 for comprehensive reviews) requires mechanism-based approaches that account for multiple processes at the population level that affect species abundances, individual traits, and the establishment of interactions (Suweis et al. 2013; Schleuning et al. 2015; Poisot et al. in press).

Mutualistic interactions, defined as interspecific resource or service exchanges from which individuals acquire fitness benefits (Bronstein 2009), are model systems for studies of network organization due to their key role in ecosystem function and, consequently, conservation schemes and economic activities, such as crop production (Bascompte 2009; Schleuning et al. 2015). Mechanistic explanations for mutualistic network organization refer to at least three general, non-exclusive processes: (i) neutral processes (Krishna et al. 2008), (ii) niche-based processes imposing forbidden links due to trait mismatches (Jordano et al. 2003), and (iii) adaptive rewiring driven by natural selection of species interactions (Suweis et al. 2013).

Neutrality approaches assume that the species within each trophic level are equivalent and that interaction probabilities are therefore proportional to relative species abundances (Krishna et al. 2008). By contrast, studies on forbidden links explore the architectural consequences of morphological mismatches between traits that mediate ecological interactions, such as size differences, or spatial and temporal differences in species occurrence (Jordano et al. 2003; Olesen et al. 2011a; Vizentin-Bugoni et al. 2014). Finally, because many mutualists are flexible with regards to their partners (Bascompte \& Jordano 2014), recent theoretical works have investigated how network organization can emerge from adaptive interaction switches (Zhang et al. 2011; Suweis et al. 2013). As no single mechanism can account for the structural variation of empirical mutualistic networks (Vázquez et al. 2009), models allowing for the integration of multiple candidate mechanisms can contribute to a better understanding of the emergence of ecological network properties. 
Mechanistic explanations for organizational patterns in mutualistic networks would also benefit from more in-depth consideration of the roles played by interspecific competition (Palmer 2003; Jones et al. 2012). Interspecific competition is expected to have pervasive structural and dynamical consequences for mutualistic networks because competition among mutualist species can force interaction switches, leading to new partner combinations (Kiers et al. 2010). Competition can also constrain attachment patterns in species interaction networks (Palmer 2003; Maeng et al. 2012) or affect the evolution of species traits mediating ecological interactions, such as seed phenology (Warren et al. 2014).

The relevance of network assembly mechanisms varies across different types of interactions. One key natural history attribute affecting mutualistic networks is interaction intimacy, which is the degree of morphological, physiological, and behavioral integration between species (Ollerton 2006). In low-intimacy mutualisms, each interaction event has a low impact on fitness, and free-living individuals interact with many individual partners. Conversely, in high-intimacy mutualisms, each interaction event has a high impact on fitness, and individuals are biologically attached to one or a few individual partners (Ollerton 2006, Guimarães et al. 2007a, Raimundo et al. 2014). Although the fitness consequences of each interaction event and the number of individual partners are often correlated, asymmetries and exceptions occur, such as millions of symbiotic microbes intimately living within a single mutualist host (Bronstein 2009), which contradicts the notion that organisms involved in high-intimacy mutualisms have few individual partners. However, even considering these conceptual limitations, contrasting species interactions with variable natural history characteristics can provide insights into the processes that shape ecological networks (e.g., Guimarães et al. 2007a, Pires \& Guimarães 2013).

Examples of low-intimacy mutualisms include associations between plants and seeddispersing animals (Herrera 1995), between plants with extrafloral nectaries (EFN plants) and protective ants (Díaz-Castelazo et al. 2013), between cleaner fishes or shrimps and their client fish species (Guimarães et al. 2007b), and between plants and pollinators (Dupont \& Hansen 2003). Nestedness is a recurrent network pattern in low-intimacy ecological interactions (Bascompte et al. 2003; Guimarães et al. 2007a, Fontaine et al. 2011, Pires \& Guimarães 2013). In a hypothetical, perfectly nested network, each species is linked only to proper subsets of species linked to more generalist species (Bascompte et al. 2003). Mathematical models suggest that the consequences of nestedness, such as competition mitigation by enhanced facilitation (Bastolla et al. 2009), would improve stability and biodiversity maintenance. In addition, as nestedness implies short average path lengths connecting any 
pair of species within the network, it can promote the rapid spread of ecological and evolutionary effects (Guimarães et al. 2007a; 2011).

High-intimacy mutualisms have tight coevolutionary histories, such as those of obligate associations between myrmecophilic plants and ants (Fonseca \& Ganade 1996), Glochidion trees and pollinating seed parasites (Hembry 2012), and anemonefish and their host sea anemones (Ricciardi et al. 2010). Intimate ecological networks exhibit, on average, lower levels of nestedness than low-intimacy networks (Fontaine et al. 2011; Pires \& Guimarães 2013) but higher levels of modularity, i.e., the occurrence of subsets of species holding dense internal connections and few connections to other subsets (Guimarães et al. 2007a; Gómez et al. 2010). Modularity is expected whenever distributional patterns or phylogenetic constraints create semi-independent groups of interacting species (Lewinsohn \& Prado 2006). In addition, coevolution creates a higher degree of reciprocal specialization between intimate mutualist species compared to low-intimacy networks (Thompson et al. 2013). The dynamic consequences of modularity and reciprocal specialization include lower susceptibility to perturbation at the network level (Olesen et al. 2007), despite the predicted higher risks of extinctions and coextinctions at the species level (Dáttilo 2012; Thebault \& Fontaine 2010).

Recent community dynamics models encompassing different types of ecological interactions have investigated the hypothesis that continuous interaction switching that maximizes species abundances is a major driver of mutualistic network organization. Existing models assume that "interaction switches" (Zhang et al. 2011) or "optimization principles" (Suweis et al. 2013) drive mutualistic network evolution, implying that natural selection favors any change in resource use that leads to increased species abundances. Approaches that relate changes in interactions (network structure) to the ecological dynamics of species (state of the nodes) can be characterized as adaptive network models (Gross \& Blasius 2008). Hence, we adopt the concept of adaptive rewiring (González-Avella et al. 2014) to describe structural evolution resulting from optimization of species abundance, which is used here as a proxy for mean individual fitness.

Here, we combine mechanistic models, dynamics analyses, and empirical data on the network structure of mutualisms with a wide variety of natural history attributes to investigate the extent to which adaptive rewiring explains the architecture of mutualistic networks and to predict its dynamic consequences. Specifically, we use an adaptive network model to investigate whether interaction switches driven by natural selection can reproduce the structural variation in a diverse set of 44 empirical ecological networks encompassing both 
low- and high-intimacy mutualistic systems. We addressed the following questions. (i) Is natural selection of interaction patterns a major process shaping the suite of network patterns observed in different types of mutualisms? (ii) What are the consequences of adaptive rewiring for system dynamics across networks with variable structural and natural history attributes? (iii) Do different ecological scenarios (different interspecific competition regimes) affect the structural and dynamic outcomes of adaptive rewiring?

\section{MODELING APPROACH AND METHODS}

\section{The model}

We developed a model describing the eco-evolutionary dynamics of a mutualistic assemblage formed by two sets of species, $A$ and $P$. Set $A$ encompasses a number $S_{A}$ of species of one mutualist type, such as pollinators, and is defined as $A=\left\{A_{1}, A_{2}, A_{3} \ldots A_{i}\right\}$, where $A_{i}$ is the $\mathrm{i}^{\text {th }}$ species of set $A$. Set $P$ comprises $S_{P}$ species of another mutualist type, such as flowering plants, and is defined as $P=\left\{P_{1}, P_{2}, P_{3} \ldots P_{i}\right\}$, where $P_{i}$ is the $i^{\text {th }}$ species of set $P$. The total number of species (species richness) is $S_{M}=S_{A}+S_{P}$. In the initial state, the abundances of species within $A$ and $P$ are sampled from lognormal distributions with mean $\mu=1$ and standard deviation $\sigma=0.5$. For any given pair of species $i\{i \in A\}$ and $j\{j \in P\}$, the product of their abundances defines an interaction probability $P_{(i, j)}$, which simulates a neutral scenario in which interactions are determined by species abundance. The network connectance, $c=$ $L /\left(S_{A} S_{P}\right)$, where $L$ is the number of links between mutualistic species, determines the total number of mutualistic interactions assigned between species of $A$ and $P$. To ensure all species have at least one mutualistic partner, the model algorithm randomly assigns a single interaction to each species and subsequently distributes the remaining links to pairs of mutualistic species sampled with probability $P_{(i, j)}$. A binary matrix $\mathbf{M}$ describes the resulting mutualistic network (Fig. 1A). The model incorporates evolutionary dynamics by simulating natural selection on mutualistic interactions (Fig. 1B), as described in the subsequent section.

Ecological dynamics are characterized by the temporal variation of species abundances as a result of survival and reproductive gains obtained from mutualistic interactions and losses due to interspecific and intraspecific resource competition. The population dynamics of species $i$ can be described as a function of the per capita effects of different types of ecological interactions on its abundance, $x_{i}$ : 


$$
\frac{d x_{i}}{d t}=x_{i}\left(\alpha_{i}-\sum_{j}^{s_{M}} T_{i j} x_{j}\right)
$$

where $\alpha_{i}$ describes the intrinsic growth rate of species $i$ in the absence of ecological interactions, $T_{i j}$ represents the effects of species $j$ on species $i$ (interaction strength), and $x_{j}$ is the abundance of species $j$. A type I functional response of mutualistic interactions is assumed. The square matrix $\mathbf{T}$ holds information on the different types of ecological interactions within the community (Fig. 1C), accounting for the per capita effects of each mutualistic and competitive interaction on the abundance of species $i$, including intraspecific competition represented in the matrix diagonal (Fig. 1D). Following Suweis et al. (2013), we define T, with dimensions $S_{M} \times S_{M}$, as follows:

$T=\left[\begin{array}{c:c}\Omega_{A A} & \Gamma_{A P} \\ \hdashline \Gamma_{P A} & \Omega_{P P}\end{array}\right]=\left(\begin{array}{ccccc:cccc}d & \omega_{1,2} & \ldots & \omega_{1, S_{A}} & \gamma_{1, S_{A}+1} & \ldots & \ldots & \gamma_{1, S_{M}} \\ \omega_{2,1} & d & \ldots & \ldots & \gamma_{2, S_{A}+1} & \ldots & \ldots & \ldots & \\ \vdots & \vdots & \vdots & \vdots & \vdots & \vdots & \vdots & \vdots \\ \omega_{S_{A}, 1} & \vdots & \cdots & d & \gamma_{S_{A}, S_{A}+1} & \cdots & \cdots & \gamma_{S_{A}, S_{M}} \\ \hdashline \gamma_{S_{A}+1,1} & \ldots & \ldots & \ldots & d & \omega_{S_{A}+1, S_{A}+2} & \ldots & \omega_{S_{A}+1, S_{M}} \\ \hdashline \gamma_{S_{A}+2,1} & \ldots & \ldots & \ldots & \ldots & & d & \ldots & \omega_{S_{A}+2, S_{M}} \\ \vdots & \vdots & \vdots & \vdots & \vdots & \vdots & \vdots & \vdots \\ \hdashline \gamma_{S_{M}, 1} & \ldots & \ldots & \ldots & \omega_{S_{M} S_{A}+1} & \ldots & \ldots & d\end{array}\right)$

Quadrats $\Gamma_{A P}$ and $\Gamma_{P A}$ in eq. 2 (yellow in Fig. 1C) describe the per capita effects of mutualistic interactions on species abundances, whereas quadrats $\Omega_{A A}$ and $\Omega_{P P}$ (light blue in Fig. 1C) summarize the corresponding per capita effects of competition. Diagonal elements (dark blue in Fig. 1C) represent intraspecific competition, $d_{i i}=1$. The quadrat $\Gamma_{A P}$ is built from the binary matrix $\mathbf{M}$ as follows. Considering a pair of mutualistic species $i\{i \in A\}$ and $j$ $\{j \in P\}$ for which $m_{(i, j)}=1$, the effect of a mutualistic species $j$ on the abundance of $i$ is defined as $\gamma_{i j} \sim-\left|\mathcal{N}\left(\mu, \sigma_{\Gamma}\right)\right|$, where $\mathcal{N}\left(\mu, \sigma_{\Gamma}\right)$ is the normal distribution with mean $\mu=0$ and standard deviation $\sigma_{\Gamma}=0.054$. The latter value ensures that all initial networks are stable (Suweis et al. 2013). Here, $|\mathrm{x}|$ is the absolute value of the sampled number. Conversely, within $\Gamma_{P A}$, the effect of species $i$ on the abundance of its partner, species $j$, is defined by a different number, $\gamma_{j i} \sim-\left|\mathcal{N}\left(\mu, \sigma_{\Gamma}\right)\right|$. Therefore, mutualistic interactions are reciprocal but not 
necessarily symmetric (Fig. 1D), as has been repeatedly observed in animal-plant networks (Bascompte et al. 2006).

Quadrats describing the effects of interspecific competition, $\Omega_{A A}$ and $\Omega_{P P}$, are built from the interaction matrices $\mathbf{C}_{\mathbf{A}}$ and $\mathbf{C}_{\mathbf{P}}$, respectively, which have the same connectance (c) as $\mathbf{M}$. However, the structures of the competitive interactions within $\mathbf{C}_{\mathbf{A}}$ and $\mathbf{C}_{\mathbf{P}}$ are independent of each other and also independent of $M$, and thus our baseline scenario assumes that species compete for resources external to the mutualistic interactions (hereafter referred to as the external resource competition scenario, CE). In contrast to mutualisms, interspecific competition for external resources is not necessarily reciprocal between $i$ and $j$, i.e., a species can affect another species without being itself affected (Fig. 1D). In addition, when $i$ competes with $j$ and vice-versa, the respective per capita effects of the interactions are not equal. The negative effect of competition with $j$ on the abundance of $i$ is $\omega_{i j} \sim\left|\mathcal{N}\left(\mu, \sigma_{\Omega}\right)\right|$, where $\mathcal{N}\left(\mu, \sigma_{\Omega}\right)$ is a normal distribution with $\mu=0$ and $\sigma_{\Omega}=\sigma_{\Gamma}$. The magnitude of the per capita effect of interspecific competition $\omega_{i j}$ can be modified by multiplying it by a constant $\alpha$, which is equal to 1 for the baseline scenario. We later relaxed the assumption that species compete for an external resource by exploring two other biologically plausible alternative scenarios of interspecific competition (see the subsection Interspecific competition scenarios, below).

\section{Adaptive rewiring algorithm}

Our adaptive rewiring algorithm implements a variational principle to characterize a mutualistic assemblage in the absence of detailed knowledge about the strengths and properties of ecological interactions (Suweis et al. 2013). The algorithm simulates natural selection, favoring changes in mutualistic interaction patterns that maximize local species abundances, which are used here as a proxy for fitness (Suweis et al. 2013). At each time step, a species $i$ is randomly sampled from $A$ or $P$ (Fig. 1C). Subsequently, a random rewire is attempted between links $i--j$ and $i--k$, where $j$ and $k$ are random species in the mutualistic partner pool. To ensure that all species in the system will have at least one mutualistic partner at any given time step, we impose the requirement that species $i, j$, and $k$ have at least two interactions. If the criterion is not met by species $i$, another random species is sampled from the network, until these requirements are fulfilled. If the criterion is not met by species $j$ or $k$, another link $i--l$ is randomly sampled, and new rewire attempts are conducted until a valid interaction switch is identified. If all the links of species $i$ have only one interaction, another 
species is sampled from the network for a new round of rewire attempts. After the rewire, species $i$ interacts with a different partner species, but the rewired link is retained only if species $i$ increases its abundance (Fig. 1D). Otherwise the switch is ignored, and a new time step begins. Simulations are run for $100 S_{M}{ }^{3 / 2}$ time steps, which is the period required to ensure that $95 \%$ of interaction switch attempts will be rejected (Suweis et al. 2013). Hereafter, we refer to final networks obtained after this number of time steps as "final" or "optimized" networks. At the end of each time step, we compute the new abundances of all species. In this approach, the new abundances were computed assuming that the ecological network moved to a new steady state. The species abundances vector $\overrightarrow{x^{*}}$ holds the stationary solution for community dynamics, which is obtained by numerical integration. At any given time step, species abundances in the rewired network are given by $\overrightarrow{x_{r}^{*}}=T^{-1} \cdot \vec{\alpha}$ (Suweis et al. 2013).

\section{Numerical simulations using empirical data from high- and low-intimacy mutualisms}

Simulation parameterization and interaction intimacy categories. We explored the extent to which our model reproduces the structural diversity of empirical mutualistic networks by parameterizing the dimensions $\left(S_{A}\right.$ and $\left.S_{P}\right)$ and connectances $(c)$ of model networks using empirical data from 44 mutualistic assemblages (see Table S1 for a detailed description of the dataset with references). Networks in our dataset encompass both high- and low-interaction intimacy systems. Low-intimacy mutualisms include 34 networks that include generalized mutualisms between plants with extrafloral nectaries (hereafter EFN plants) and ants (PA), plant-pollinator interactions (PP), mutualisms between plants and their animal seed dispersers (PS), and marine mutualisms between cleaner species and their client fishes (CC). High-intimacy mutualisms encompass 10 networks, including obligate mutualisms between myrmecophilic plants and associated ant species (SPA) and between anemone fishes and their host sea anemones (AF). High- and low-intimacy mutualisms exhibit contrasting structural properties that likely engage in feedback with evolutionary and ecological dynamics (Fig. S1).

Interspecific competition scenarios. We defined three interspecific competition scenarios to investigate the effects of competition on the structure and stability of optimized networks. In the baseline scenario, species within mutualist sets $A$ and $P$ compete for resources external to mutualistic interactions (external resource competition scenario, CE). A second scenario assumes that species compete for mutualistic partners (competition for mutualists scenario, CM). Under CM, we used the overlap in mutualistic interactions as a 
proxy for interspecific competition. Our estimates of the interspecific competition weights, interaction strengths and competitive networks are defined as $\Omega_{A A}=\Gamma_{A P} \times \Gamma_{P A}{ }^{\mathrm{T}}$ and $\Omega_{P P}=\Gamma_{P A}$ $\times \Gamma_{A P}{ }^{\mathrm{T}}$. A third scenario (absence of competition, scenario NC) assumes that interspecific competition does not occur and that $\Omega_{A A}$ and $\Omega_{P P}$ are filled with zeroes, except for the diagonal elements, which, as in all scenarios, are defined as $d_{i i}=1$.

\section{Assessing the effects of adaptive rewiring on mutualistic networks}

For each combination of empirical mutualistic network ( $n=44$ networks) and interspecific competition scenario (3), we conducted 1,000 simulation replicates. In each simulation, the structure of the community matrix $\mathbf{T}$ was defined by the same empirically informed dimensions and connectances. However, the initial strength of each ecological interaction was defined as described above. We described the structural variation arising from adaptive rewiring by comparing the initial networks, in which interaction probabilities are given by relative species abundances, to the final, optimized networks. Specifically, we computed the nestedness and modularity of the initial and final mutualistic networks (matrix $\mathbf{M}$ ) using the metrics NODF (Almeida-Neto et al. 2008) and $Q$ (Barber 2007). The latter was computed using the simulated annealing optimization method (Marquitti et al. 2014). The indicators $\triangle N O D F$ (nestedness) and $\triangle Q$ (modularity) describe structural changes across time and are defined as $\triangle N O D F=\left(N O D F_{f}-N O D F_{i}\right) / N O D F_{i}$ and $\triangle Q=\left(Q_{f}-Q_{i}\right) / Q_{i}$. Because network connectance and species richness are held constant between the initial and final networks, these measures describe the relative increase (positive values of $\triangle N O D F$ or $\triangle Q$ ) or decrease (negative values of $\triangle N O D F$ or $\triangle Q$ ) in nestedness and modularity.

To evaluate the effects of adaptive rewiring on the ecological dynamics of mutualistic assemblages, we assessed local stability, i.e., the extent to which species abundances return to equilibrium after small perturbations (McCann 2000). We assessed stability for each simulation replicate using the real part of the leading eigenvalue, $\lambda_{\mathbb{R}}$, of the Jacobian matrix $\mathbf{J}=-\mathbf{T} \cdot \overrightarrow{x^{*}}$ (see May 1973; Allesina \& Tang 2012; Suweis et al. 2013 for similar approaches). Positive and negative values of $\lambda_{\mathbb{R}}$ indicate unstable and stable networks, respectively. Among negative values, lower values imply higher resilience, i.e., the system returns to equilibrium faster. For each simulation, the indicator $\Delta \lambda_{R}=\left[\lambda_{R(\mathrm{i})}-\lambda_{R(\mathrm{f})}\right] /\left|\lambda_{R(\mathrm{i}}\right|$ is an index representing the relative variation in stability between initial $\left[\lambda_{\mathbb{R}(\mathrm{i})}\right]$ and final $\left[\lambda_{\mathbb{R}(\mathrm{f})}\right]$ 
networks. Positive and negative values of $\Delta \lambda_{\mathbb{R}}$ indicate decreasing and increasing stability, respectively.

Statistical analyses. Comparisons among the mean values of structural descriptors were possible because the structural changes in our simulations reached asymptotic levels (Fig. S2). To determine if two explanatory variables, species richness $\left(S_{M}\right)$ and connectance (c), determine structural changes arising from adaptive rewiring, we performed regression analyses in which we used the median values structural descriptors ( $\triangle N O D F$ and $\triangle \mathrm{Q})$ in each network ( $n=44$ networks, 30 simulation replicates per network) as response variables. As a consequence of multicollinearity among explanatory variables, multiple regressions cannot be used to assess the relative effects of each candidate predictor on response variables. Under such a limitation, the coefficients of determination $\left(R^{2}\right)$ of simple linear regressions provide comparisons of goodness-of-fit among different potential predictors (James et al. 2012). We followed a similar approach for assessing the dynamical consequences of adaptive rewiring, using the values of $\Delta \lambda_{R}$ as the response variable and the species richness, connectance, and mean values of $\triangle N O D F$ and $\triangle \mathrm{Q}$ for each network as explanatory variables. Whenever necessary, variables were log-transformed to improve normality and homoscedasticity. When variable values included negative numbers, we added a constant to them before log transformation.

To determine the extent to which final (optimized) networks and initial (probabilistic) networks reproduced structurally equivalent empirical networks, we used an index measuring the standardized error for a given structural property: $E_{P}=\left(P_{t}-P_{N}\right) / P_{N}$, where $P_{t}$ is the median of NODF or Q values computed for an ensemble of theoretical networks $(n=44$ networks, 30 simulation replicates per network) and $P_{N}$ is the $N O D F$ or $Q$ value observed in the corresponding empirical mutualistic network. We thus computed the variation of the standardized model error before and after network optimization as $\Delta E=\left|E_{P(f)}\right|-\left|E_{P(i)}\right|$, in which $f$ indicates the final network and i corresponds to the initial network. Negative values of $\Delta E$ indicate that the final networks reproduce the empirical property more accurately than the initial network. Conversely, positive values of $\Delta E$ indicate that adaptive rewiring decreases the fit between the simulated and empirical network structures. We performed two-tailed Wilcoxon signed-rank tests to identify significant differences in the standardized errors of each structural property between the initial and final networks.

For cases in which network optimization by adaptive rewiring improved the fit between model and empirical structures, we characterized the accuracy of the structural fit 
between the final (optimized) networks and their empirical counterparts by computing the normalized model error [NME, see Williams \& Martinez (2008) and Pires et al. (2011) for similar approaches] between the empirical estimates of nestedness $\left(N O D F_{E}\right)$ or modularity $\left(Q_{\mathrm{E}}\right)$ and their counterparts in the optimized model networks $\left({\overline{N O D F_{f}}}_{\text {or }} \bar{Q}_{f}, n=1,000\right.$ replicates per network and interspecific competition scenario, totaling 102,000 simulations ( $n$ $=34$ low-intimacy networks). NME is computed as the difference between the median value of a model structural property and its empirical counterpart, divided by the difference between the model median value for the property and the model value at the $2.5 \%$ or $97.5 \%$ quantiles. The former is used if the empirical value is lower than the model median, and the latter is used otherwise (Pires et al. 2011). If a model error has an absolute value greater than one, then the empirical property value is not within the $95 \%$ most likely model property values and is therefore considered different from the distribution of property values computed from the model (Williams \& Martinez 2008). Finally, we used a one-way analysis of variance (ANOVA) to investigate the effects of the three previously described interspecific competition scenarios on the stability of the networks emerging by adaptive rewiring. We used the three different competition scenarios as levels of the same factor and the mean value for 1,000 simulation replicates for each network and competition scenario as the response variable.

\section{Caveats}

We used empirically informed network dimensions and connectances to characterize the structural diversity of mutualistic networks. These parameters are major drivers of structural evolution, and thus the accuracy of their empirical estimates is a key aspect to assure the validity of inferences derived from model adaptive networks. However, a variety of sources, such as methodological assumptions, variable effort, and a variety of observation errors, can lead to sampling problems that will cause the observed properties to deviate from the "true" network structure (Vázquez et al. 2009). The datasets used in this study were derived from published studies (Table S1). However, it is not possible to ensure that sampling methods are comparable, for instance, across different types of plant-pollinator systems. Therefore, further modeling of adaptive rewiring based on controlled sampling efforts to build interaction matrices that are comparable across different types of mutualistic system would be useful to test the generality of the inferences presented here. Whenever possible, to improve modeling possibilities, studies depicting ecological networks should also provide independent 
estimates of species abundances because the frequency of interactions is a poor proxy for actual species abundance when both values are uncorrelated (Vizentin-Bugoni et al. 2014).

We assumed that all links of a given species have equal probabilities of undergoing a rewiring event and that the link being switched is randomly assigned to one of the remaining mutualistic species. Further studies could explore the structural and dynamical consequences of alternative, biologically plausible rewiring rules, including, for example, the assignment of varying probabilities of a rewiring event to generalist and specialist species (see RamosJiliberto et al. 2012 for diverse biologically plausible rewiring rules) or assignment based on phylogenetic criteria.

\section{RESULTS}

\section{General effects of adaptive rewiring on model mutualistic networks}

Adaptive rewiring led to the emergence of nestedness in the model mutualistic networks. On average, the optimized networks exhibited higher nestedness $(\overline{\triangle N O D F}=30 \% \pm 28 \%$, paired $t$-test, $t=5.6, P<0.0001, n=44$ networks $)$ and lower modularity $(\overline{\Delta Q}=-5 \% \pm 6 \%$, paired $t$ test, $t=-7.06, P<0.0001, n=44$ networks) than their initial states (Fig. 2A). The species richness $\left(S_{M}\right)$ and connectance $(c)$ of the networks did not affect the degree of nestedness resulting from adaptive rewiring (Fig. S3A-B). However, modularity variation was positively affected by connectance $\left(R^{2}=0.28, P<0.001\right)$, although it was not related to species richness (Fig. S3C-D).

The initial species abundances were not related to the final species abundances $\left(R^{2}=0.0001, P=0.99\right)$. Moreover, the most connected species in the initial networks were not those with more links in the final, optimized networks $\left(R^{2}=0.01, P=0.49\right)$. By contrast, the final species abundances and degrees were positively related $\left(R^{2}=0.596, P<0.0001\right)$. The optimized networks thus differed from the initial probabilistic networks, not only in abundance distributions but also in the relative roles of the species within the networks, i.e., which species are central and peripherals nodes (Fig. S4).

Stability decreased in model networks as a consequence of adaptive rewiring $\left(\overline{\Delta \lambda_{\mathbb{R}}}=\right.$ $45 \% \pm 40 \%$, paired $t$-test, $t=7.8, P<0.0001, n=44$ networks). Qualitatively similar results were obtained under different assumptions about the initial distribution of abundances (Fig. S5). Variation in stability $\left(\Delta \lambda_{\mathbb{R}}\right)$ was positively related to the attainment of nestedness 
$\left(\triangle N O D F, R^{2}=0.4, P<0.0001\right)$ and to species richnesses $\left(S_{M}, R^{2}=0.45, P<0.0001\right.$, fig. S3EF). Therefore, adaptive rewiring promotes an overall increase in nestedness in model mutualistic networks despite their species richnesses, but the destabilizing effects of such structural changes are more severe in species-rich, highly nested networks.

\section{Structural fit between model and empirical networks}

The structural fit between the model and empirical networks varied among different types of mutualisms (Fig. 3A). For low-intimacy mutualisms, adaptive rewiring decreased model errors (Wilcoxon signed-rank test, $V_{N O D F}=39, P_{N O D F}<10^{-6}, V_{Q}=511, P_{Q}<10^{-4}$ ), with optimized networks reproducing the nestedness [median $E_{N O D F(f)}=-0.04$, Fig. 3B] and modularity [median $E_{Q(f)}=-0.02$, Fig. 3C] of empirical networks more accurately than the initial, neutral networks [median $E_{N O D F(i)}=-0.28$, Fig. 3B; median $E_{Q(i)}=0.04$, Fig. 3C]. By contrast, for intimate mutualisms, the optimized and initial networks did not differ in reproducing nestedness [median $E_{N O D F(i)}=0.42$, Fig. 3B; median $E_{N O D F(f)}=0.78$, Fig. 3C; Wilcoxon signed-rank test, $\left.V_{N O D F}=19, P_{N O D F}=0.72\right]$, although the optimized networks reproduced the modularity of the empirical networks slightly better than the initial networks [median $E_{Q(i)}=0.16$ and $E_{Q(f)}=0.09$; Wilcoxon signed-rank test, $V_{Q}=55, P_{Q}<10^{-3}$ ]. Importantly, by increasing nestedness, adaptive rewiring drives the structure of model lowintimacy networks closer to those of empirical architectures, whereas the same trend causes high-intimacy model networks to depart from empirical structures (Fig. 3B).

Because the adaptive rewiring models failed to reproduce the empirical structures of high-intimacy mutualistic networks, we proceeded to evaluate the model agreement for each optimized network and its empirical counterpart, considering only low-intimacy mutualisms. The extent to which the structure of low-intimacy networks was reproduced by the model varied among different types of biological systems (Fig. 4). Regardless of the interspecific regime assumed, the percentage of networks for which empirical nestedness fell within the 95\% most likely values of model properties (i.e., absolute NME values between 0 and 1) was higher for mutualisms between EFN plants and ants and for seed dispersal mutualisms, whereas empirical modularity was more accurately reproduced by our simulations of plantseed dispersers and plant-pollinator networks (Table 1). Because at least one species will be extinct whenever $\lambda_{\mathbb{R}(\mathrm{f})}>0$ (Fig. S6), we conducted a complementary NME analysis for lowintimacy networks in which we considered a subset of model networks including only stable 
communities $\left(\lambda_{\mathbb{R}(\mathrm{f})}<0\right)$. The structural fit between empirical mutualistic networks and the stable networks subset (Fig. S7) was qualitatively the same as the results for all networks presented in Fig. 4.

\section{Interspecific competition regimes and dynamics of mutualistic assemblages}

We did not detect differences in the network structures of optimized networks in different interspecific competition scenarios (Fig. 4). Similarly, the mean final stability $\left[\overline{\lambda_{\mathbb{R}(\mathrm{f})}}\right]$ of model low-intimacy networks was not significantly different across competition scenarios $\left(F_{99,2}=1.4, P=0.23\right)$, despite a strong qualitative effect of competition scenarios on mean competition strength (Fig. S8). Increasing the strength of interspecific competition (by multiplying matrices $\Omega_{A A}$ and $\Omega_{P P}$ by higher values of constant $\alpha$ ) decreased the degree of nestedness, increased modularity, and led to unstable communities at higher values of $\alpha$ (Fig. S9).

The rewiring dynamics were qualitatively different among different interspecific competition scenarios. Adaptive rewiring stops when the stability reaches asymptotic levels in the absence of interspecific competition (NC) or when species compete for external resources (CE). However, in complementary simulations considering a hypothetical assemblage $\left(S_{M}=\right.$ $50 ; S_{A}=25 ; S_{P}=25$ ), we observed that if species compete for mutualistic partners, rewiring events continue to accumulate even after nestedness (NODF) and stability $\left[\lambda_{\mathbb{R}(\mathrm{f})}\right]$ are asymptotic (Fig. 5), leading to never-ending adaptive dynamics. The latter scenario, in which species compete for mutualist partners (CM), also exhibited lower mean species abundances than the other scenarios (Fig. S10).

\section{DISCUSSION}

\section{General effects of adaptive rewiring on model mutualistic networks}

Adaptive rewiring was hypothesized as a general mechanism accounting for the properties of any type of mutualism (Zhang et al. 2011; Suweis et al. 2013). Our results challenge this hypothesis by demonstrating that the structure of high-intimacy networks cannot be explained by adaptive rewiring. Adaptive interaction switches have the potential to be a major determinant of structural properties of species-rich, low-intimacy mutualisms, such as seed 
dispersal and pollination systems, for which high turnover rates have been reported (Olesen et al. 2011b; Díaz-Castelazo et al. 2013). However, species interactions in high-intimacy mutualisms are persistent over evolutionary time, and rewiring events are reported to be extremely rare (Pellmyr 2003; Kawakita \& Kato 2009). We hypothesize that other processes, such as diversifying coevolution (Thompson 2005), must be invoked to explain the structure and function of networks describing interactions between reciprocally specialized species, such as obligate mutualisms between anemones and anemone fishes and between ants and myrmecophyte plants.

Although nestedness is expected under the assumption that interactions are neutral (Krishna et al. 2008, Vázquez et al. 2009), we have demonstrated here that changes in interaction patterns due to natural selection may increase nestedness in model networks depicting species-rich mutualisms among free-living species. Importantly, this increase in nestedness improved the fit between the structural properties (nestedness and modularity) of the optimized and empirical networks compared to the initial, neutral networks. Nestedness increases have implications for community stability. The changes in nestedness promoted by adaptive rewiring were positively related to $\Delta \lambda_{\mathbb{R}}$, implying that the model networks were less likely to be stable after optimization. Importantly, the destabilizing effects of the increase in nestedness were more severe in species-rich model networks. We thus predict that, under strong natural selection, unusually nested mutualistic networks will be more common under low-to-intermediate species richness because highly nested networks with higher numbers of species are less likely to persist over time. Indeed, there is evidence suggesting that mutualistic networks characterized by higher nestedness than expected under null models are more common in networks of intermediate dimensions (Joppa et al. 2010).

\section{Structural fit between the model and empirical networks}

Optimized model networks have repeatedly overestimated the nestedness of highintimacy mutualisms. In fact, the degrees of nestedness of empirical high-intimacy networks are lower than those of the initial, probabilistic networks based on abundance patterns. Therefore, mechanisms other than adaptive interaction switches or neutral processes are needed to explain the low nestedness and high modularity that characterize empirical intimate mutualistic networks (Fig. S1). We hypothesize that the differences between our results and the empirical structures are related to tight coevolutionary relationships involving intimate 
mutualistic partners, in which rewiring events are reported to be extremely rare (Pellmyr 2003; Kawakita \& Kato 2009). Coadaptations within high-intimacy networks can generate complex sets of integrated mutualism-related traits, minimizing the likelihood of adaptive rewiring (Fonseca \& Ganade 1996) and leading to modular networks that include completely isolated groups of species characterized by symmetric interactions (Guimarães et al. 2007a). Indeed, reciprocal adaptations between partner species and phylogenetic patterns of associations occur in mutualisms between ants and myrmecophyte plants, which comprise most of our high-intimacy networks. For example, Amazonian assemblages of ants and myrmecophytes display non-random associations and form geographically recurrent compartments in which phylogenetically related plants share ant species from different phylogenetic lineages (Fonseca \& Ganade 1996). Phylogenetic correlations between mutualists do not occur in assemblages of anemone fishes and their hosts (closely related fishes use unrelated anemone species), but pressures toward specialization arising from interspecific competition could be the mechanism constraining nestedness in these systems (Ricciardi et al. 2010).

In low-intimacy mutualisms, adaptive rewiring promoted an overall improvement of the structural fit between the model and empirical networks. In contrast to high-intimacy interactions, species involved in low-intimacy mutualisms are often flexible regarding their morphological and foraging attributes. Thus, interaction switches favoring connections with more abundant and/or profitable partners are more likely to occur (Bascompte \& Jordano 2014). However, the structural plasticity of low-intimacy networks is heterogeneous across the four types of mutualisms considered here, which is expected because these systems include species with variable natural history attributes and foraging traits. Below, we summarize the ecological and evolutionary processes that favor rewiring in different types of low-intimacy mutualistic networks and, conversely, processes that constrain the interaction switches that promote the adaptive emergence of nestedness.

Seed dispersal mutualisms. Ecologically based switching behavior can be ubiquitous in plant-frugivore mutualisms, as suggested by the accurate fit between structures arising from our adaptive rewiring models and those of empirical networks (Fig. 4) and by predictions derived from other models of adaptive interaction switches across different types of mutualisms (Zhang et al. 2011). The recurrence of network rewiring in seed dispersal systems may arise from spatial and temporal variation in fruit availability (Jordano 2000) and the lack of tight mutual coevolutionary adjustments between species traits (Herrera 1995; Jordano 2000). For example, wide seasonal variation in network structure is driven by short- 
term changes in local resource abundance (including both fruits and alternative resources external to the mutualisms, such as insects) in a Mediterranean assemblage, although behavioral rewiring is constrained by morphological traits (Carnicer et al. 2009). Rewiring is also promoted by functional extinctions of frugivores, such as large-gape seed dispersers in the Brazilian Atlantic Forest (Galetti et al. 2013), with structural and evolutionary consequences for local networks within defaunated forest fragments.

Plant-pollinator mutualisms. Interaction rewiring pervades plant-pollination mutualisms across temporal scales. For example, structural variation including gain, losses, and rewiring of interactions has been reported in a study encompassing data on local interactions between forbs and their bee pollinators over 120 years (Burkle et al. 2013). At the other extreme of temporal scale, an Arctic pollination network exhibits phenological turnover of both pollinators and plants on a daily basis, and species entering the system interact preferentially with abundant, highly connected partners (Olesen et al. 2008). Although rewiring is common in plant-pollinator mutualisms, our adaptive rewiring model exhibited lower performance in reproducing empirical pollination networks than seed dispersal networks (Table 1). There is empirical evidence that pollination often relies on multiple traits mediating interactions, even when the mutualism is not obligate (Thompson et al. 2013). By contrast, seed dispersal is often limited by body size (and correlated traits), and thus interaction switches do not require organisms to undergo further adaptations beyond the ability to manipulate and digest fruits (Herrera 1995; Jordano 2000). We thus corroborate the notion that forbidden links shape pollination networks more frequently than seed dispersal networks (e.g., Olesen et al. 2011a).

Mutualisms between ants and EFN plants. Normalized model errors (NME) analysis demonstrated that empirical nestedness fell within the $95 \%$ most likely corresponding model properties (Fig. 4), confirming that the adaptive rewiring model reproduces the structure of mutualistic networks of ants and EFF plants. However, this result should be considered cautiously due to the very limited number of datasets we used for this type of system. Despite this limitation, it has been empirically demonstrated that the core of generalist ants are competitively superior species whose dominance hierarchy can explain nestedness (Dáttilo et al. 2014). Because extrafloral nectar is a predictable key resource for ants, adaptive network rewiring is expected to occur and even be amplified under a strong hierarchy of competitive dominance, which favors adaptive changes in resource use. In addition, other mechanisms, such as daily turnovers in the myrmecofauna attending extrafloral nectaries (e.g., Cogni et al. 2000) can also favor resource partitioning among ant species, contributing to the persistence 
and increased connectivity of peripheral species and thus potentially contributing to nestedness.

Client-cleaner mutualisms. The degree of nestedness held by client-cleaner systems is among the highest recorded to date among mutualistic systems, surpassing plant-pollinator assemblages (Guimarães et al. 2007b). Such a highly nested structure has been associated with lower phylogenetic constraints compared to other mutualisms, which allows variation in species abundances and favors the ecological generalization subjacent to nestedness (Guimarães et al. 2007b). Evidence from coral reef communities supports the notion that species traits, such as body size, have weak effects on client-cleaner network structures, which are primarily driven by species abundances (Floeter et al. 2007). Even considering the limited number of networks we used for this type of mutualism, it is clear that our models failed to reproduce the architecture of client-cleaner networks and underestimated their nestedness. Assemblages of shrimps and fishes foraging for ectoparasites on client fishes are thus likely to be subjected to other processes that contribute to their outstanding degrees of nestedness, which are higher than would be expected based on species abundance distributions alone or based on adaptive rewiring (Fig. S11). A candidate explanation would be reduced interspecific competition among mutualist species, which would allow wider client overlap between the few cleaner species. Although empirical evidence indicates that cleaner species do compete for clients, coexistence can occur if competing cleaners use distinct resources in the same client species. For example, in bird-mammal cleaning networks, birds clean the same mammal species but exhibit wide variation in the type of client resources on which they forage (Sazima et al. 2012). Accordingly, context-dependent cheating, in which competitively inferior cleaner species forage for client mucus or tissues instead of client ectoparasites, can also contribute to species persistence in the face of competition (Adam \& Horii 2012).

\section{Interspecific competition scenarios and the dynamics of mutualistic assemblages}

Network structure and interaction type mixing synergistically affect population dynamics, indicating that the effects of community structure on stability cannot be properly evaluated without considering the community context (Mougi \& Kondoh 2012; Fontaine et al. 2011). For example, the properties of competitive networks can determine species coexistence within a community, with non-hierarchical networks supporting more diverse communities (Allesina \& Levine 2011). We demonstrated that although adaptive rewiring under different 
interspecific competition scenarios does not result in different ecological patterns (network structure), distinct competitive regimes embedded within mutualistic interactions imply qualitatively different evolutionary dynamics (network turnover). Mutualisms are expected to evolve in ways that maximize mutual benefit between interacting partners, and theoretical models often predict that evolutionary dynamics lead to asymptotic, stable phenotype or genotypic patterns (Müller 1879; Nuismer et al. 1999; Guimarães et al. 2011). In our models, when species compete for potential mutualistic partners, interaction switching occurs continuously, even after the point at which the overall network structure does not undergo further changes. By contrast, rewiring events reach asymptotic levels when species compete for external resources or when interspecific competition is absent (Fig. 5). Competition for mutualistic partners, therefore, may provide a potential mechanism for the observed high rates of turnover in interaction patterns of component species within assemblages characterized by stable patterns at the network level (Olesen et al. 2011b; Díaz-Castelazo et al. 2013). Moreover, these results generalize to empirical and theoretical inferences suggesting that other types of ecological interactions markedly affect the dynamics of mutualisms (Thompson 2005; Jones et al. 2012).

\section{Concluding remarks}

The effects of interspecific competition types on mutualistic network dynamics observed our model reinforces that the relationships between structural and dynamical properties of ecological networks are critically dependent on the diversity of ecological interactions (Fontaine et al. 2011; Mougi \& Kondoh 2012). Constructing robust theoretical conclusions in the face of a diversity of community dynamics model structures and diverse assumptions about how ecological interactions occurs remains as a future challenge. The magnitude of this challenge can be evaluated based on highly variable modeling approaches and their conflicting predictions for relationships between structure and stability. In the model used by Okuyama \& Holland (2011), for example, resilience is enhanced by increasing species richness, connectance, and nestedness. Nestedness has also been suggested to minimize coextinctions (Thebault \& Fontaine 2010) and interspecific competition (Bastolla et al. 2009) in mutualistic networks. By contrast, Allesina \& Tang (2012), using qualitative stability analysis (May 1973), demonstrated that stability is negatively affected by nestedness in mutualisms. A negative relationship between nestedness and stability holds in models that incorporate adaptive rewiring (e.g., Zhang et al. 2011; Suweis et al. 2013), particularly for 
species-rich networks (as in this study). Because consensus about the dynamic implications of nestedness has not been reached, a general explanation that integrates the processes driving the pervasive architectural pattern of mutualisms remains a major ecological challenge.

In this study, we have dismissed the notion that adaptive rewiring is a general process shaping the structure of mutualistic networks. Furthermore, we identified low-intimacy mutualistic systems in which adaptive interaction switches are likely to be a major driver of network evolution. We also identified other types of high-intimacy mutualistic networks in which other processes, such as diversifying coevolution, must be invoked to explain the structural patterns. Importantly, we have demonstrated that, whenever adaptive rewiring matters, it leads to an inverse relationship between diversity and stability, with a greater effect of the destabilizing effects arising from adaptively emerging nestedness on species-rich networks. Finally, we note that the interplay between mutualisms and interspecific competition is an alternative, promising line of investigation for understanding the mechanisms shaping mutualistic assemblages (Jones et al. 2012), as illustrated here by the variation in rewiring dynamics under different interspecific competition scenarios.

\section{ACKNOWLEDGMENTS}

We are grateful to Flávia M. D. Marquitti and Pedro Jordano for suggestions and criticism to an earlier version of the manuscript. The São Paulo Research Foundation (FAPESP) supported R. L. G. R. (grant \#2011/13054-6), M. M. P. (grant \#2009/54567-6) and P. R. G (grant \#2009/54422-8). CAPES supported V. A. G. B. (grant \#1002302). R. L. G. R. also received financial support from CAPES. P. R. G. was also supported by CNPq.

\section{REFERENCES}

Adam, T. C. \& Horii, S. S. (2012). Patterns of resource-use and competition for mutualistic partners between two species of obligate cleaner fish. Coral Reefs, 31, 1149-1154.

Allesina, S. \& Levine, J.M. (2011). A competitive network theory of species diversity. Proceedings of the National Academy of Sciences, 108, 5638-5642.

Allesina, S. \& Tang, S. (2012). Stability criteria for complex ecosystems. Nature, 483, 205208.

Almeida-Neto, M., Guimarães, P., Guimarães, P.R., Jr, Loyola, R.D. \& Ulrich, W. (2008). A consistent metric for nestedness analysis in ecological systems: reconciling concept and measurement. Oikos, 117, 1227-1239. 
Barber, M. J. (2007). Modularity and community detection in bipartite networks. Physical Review E, 76, 066102.

Bascompte, J. \& Jordano, P. (2007). Plant-animal mutualistic networks: the architecture of biodiversity. Annual Review of Ecology, Evolution, and Systematics, 38, 567-593.

Bascompte, J. (2009). Mutualistic networks. Frontiers in Ecology and the Environment, 7, 429-436.

Bascompte, J. \& Jordano, P. (2014). Mutualistic networks. Princeton University Press, Princeton, New Jersey.

Bascompte, J., Jordano, P. \& Olesen, J. (2006). Asymmetric coevolutionary networks facilitate biodiversity maintenance. Science, 312, 431-433.

Bascompte, J., Jordano, P., Melián, C.J. \& Olesen, J. (2003). The nested assembly of plantanimal mutualistic networks. Proceedings of the National Academy of Sciences, 100, 93839387.

Bastolla, U., Fortuna, M. A., Pascual-García, A., et al. (2009). The architecture of mutualistic networks minimizes competition and increases biodiversity. Nature, 458, 1018-1021.

Bronstein, J.L. (2009). Mutualism and Symbiosis. In: The Princeton Guide to Ecology (ed. Levin, S.). Princeton University Press, Princeton.

Burkle, L. A., Marlin, J. C. \& Knight, T. M. (2013). Plant-pollinator interactions over 120 years: loss of species, co-occurrence, and function. Science, 339, 1611-1615.

Carnicer, J., Jordano, P. \& Melián, C. J. (2009). The temporal dynamics of resource use by frugivorous birds: a network approach. Ecology, 90, 1958-1970.

Cogni, R., Raimundo, R. L. G. \& Freitas, A. V. L. (2000). Daily activity of ants associated with the extrafloral nectaries of Turnera ulmifolia (Turneraceae) in a suburban area in Southeast Brazil. Entomologist's Monthly Magazine, 136, 141-147.

Dáttilo, W. (2012). Different tolerances of symbiotic and nonsymbiotic ant-plant networks to species extinctions. Network Biology, 2, 127-138.

Dátillo, W., Díaz-Castelazo, C. \& Rico-Gray, V. (2014). Ant dominance hierarchy determines the nested pattern in ant-plant networks. Biological Journal of the Linnean Society, 113, 405414.

Díaz-Castelazo, C., Sánchez-Galván, I.R., Guimarães, P.R., Jr, Raimundo, R.L.G. \& RicoGray, V. (2013). Long-term temporal variation in the organization of an ant-plant network. Annals of Botany, 111, 1285-1293.

Dupont, Y. \& Hansen, D. (2003). Structure of a plant-flower-visitor network in the highaltitude sub-alpine desert of Tenerife, Canary Islands. Ecography, 26, 301-310. 
Floeter, S. R., Vázquez, D. P., Grutter, A. S. (2007). The macroecology of marine cleaning mutualisms. Journal of Animal Ecology, 75, 104-111.

Fonseca, C.R. \& Ganade, G. (1996). Asymmetries, compartments and null interactions in an Amazonian ant-plant community. Journal of Animal Ecology, 65, 339-347.

Fontaine, C., Guimarães, P.R., Jr, Kéfi, S., Loeuille, N., Memmott, J.J., van der Putten, W.H., et al. (2011). The ecological and evolutionary implications of merging different types of networks. Ecology Letters, 14, 1170-1181.

Galetti, M., Guevara, R., Côrtes, M. C., Fadini, R., Von Matter, S., Leite, A. B., et al. (2013). Functional extinctions of birds drive rapid evolutionary changes in seed size. Science, 340, 1086-1090.

Gómez, J.M., Verdú, M. \& Perfectti, F. (2010). Ecological interactions are evolutionarily conserved across the entire tree of life. Nature, 465, 918-921.

González-Avella, J.C., Cosenza, M.G., Herrera, J.L. \& Tucci, K. (2014). Emergence and persistence of communities in coevolutionary networks. Europhysics Letters, 107, 28002.

Gross, T. \& Blasius, B. (2008). Adaptive coevolutionary networks: a review. Journal of The Royal Society Interface, 5, 259-271.

Guimarães, P.R., Jr, Jordano, P. \& Thompson, J.N. (2011). Evolution and coevolution in mutualistic networks. Ecology Letters, 14, 877-885.

Guimarães, P.R., Jr, Rico-Gray, V., Oliveira, P.S., Izzo, T.J., Reis, Dos, S.F.F. \& Thompson, J.N. (2007a). Interaction intimacy affects structure and coevolutionary dynamics in mutualistic networks. Current Biology, 17, 1797-1803.

Guimarães, P.R., Jr, Sazima, C., Reis, Dos, S.F.F. \& Sazima, I. (2007b). The nested structure of marine cleaning symbiosis: is it like flowers and bees? Biology Letters, 3, 51-54.

Hembry, D. (2012). Coevolutionary diversification of leafflower moths (Lepidoptera: Gracillariidae: Epicephala) and leafflower trees (Phyllanthaceae: Phyllanthus sensu lato [Glochidion]) in southeastern Polynesia. PhD Thesis, University Of California, Berkeley.

Herrera, C.M. (1995). Plant-vertebrate seed dispersal systems in the Mediterranean: ecological, evolutionary, and historical determinants. Annual Review of Ecology and Systematics, 705-727.

James, A., Pitchford, J.W. \& Plank, M.J. (2012). Disentangling nestedness from models of ecological complexity. Nature, 487, 227-230.

Jones, E.I., Bronstein, J.L. \& Ferriere, R. (2012). The fundamental role of competition in the ecology and evolution of mutualisms. Annals of the New York Academy of Sciences, 1256, $66-88$.

Joppa, L.N., Montoya, J.M., Solé, R., Sanderson, J. \& Pimm, S.L. On nestedness in ecological networks. Evolutionary Ecology Research, 12, 35-46. 
Jordano, P. (2000). Fruits and frugivory. In: Seeds: the ecology of regeneration in plant communities (ed. Fenner, P.). CABI Publ., Wallingford.

Kawakita, A. \& Kato, M. (2009). Repeated independent evolution of obligate pollination mutualism in the Phyllantheae-Epicephala association. Proceedings of the Royal Society B, 276, 417-426.

Kiers, T.E., Palmer, T.M., Ives, A.R., Bruno, J.F. \& Bronstein, J.L. (2010). Mutualisms in a changing world: an evolutionary perspective. Ecology Letters, 13, 1459-1474.

Krishna, A., Guimarães, P.R., Jr, Jordano, P. \& Bascompte, J. (2008). A neutral-niche theory of nestedness in mutualistic networks. Oikos, 117, 1609-1618.

Levin, S.A. (1992). The problem of patterns and scale in Ecology. Ecology, 73, 1943-1967.

Lewinsohn, T. M. \& Prado, P.I. (2006). Structure in plant-animal interaction assemblages. Oikos, 113, 174-184.

Maeng, S.E., Lee, J.W. \& Lee, D.S. (2012). Interspecific competition underlying mutualistic networks. Physical Review Letters, 108, 108701.

Marquitti, F.M.D., Guimarães, P.R., Jr, Pires, M.M. \& Bittencourt, L.F. (2014). MODULAR: software for the autonomous computation of modularity in large network sets. Ecography, 37, 221-224.

May, R. M. (1973). Qualitative stability in model ecosystems. Ecology, 54, 638-641.

McCann, K. (2000). The diversity-stability debate. Nature, 405, 228-233.

Mougi, A. \& Kondoh, M. (2012). Diversity of interaction types and ecological community stability. Science, 337, 349-351.

Müller, F. (1879). Ituna and Thyridia; a remarkable case of mimicry in butterflies. Transactions of the Entomological Society of London, 1879, xx-xxix.

Nuismer, S.L., Thompson, J.N. \& Gomulkiewicz, R. (1999). Gene flow and geographically structured coevolution. Proceedings of the Royal Society B, 266, 605-609

Okuyama, T. \& Holland, J.N. (2008). Network structural properties mediate the stability of mutualistic communities. Ecology Letters, 11, 208-216.

Olesen, J. M., Bascompte, J., Dupont, Y.L. \& Jordano, P. (2007). The modularity of pollination networks. Proceedings of the National Academy of Sciences, 104, 19891.

Olesen, J. M., Bascompte, J., Elberling, H. \& Jordano, P. (2008). Temporal dynamics in a pollination network. Ecology, 89, 1573-1582.

Olesen, J. M., Bascompte, J., Dupont, Y.L., Elberling, H., Rasmussen, C. \& Jordano, P. (2011a). Missing and forbidden links in mutualistic networks. Proceedings of the Royal 
Society $B, 278,725-732$.

Olesen, J. M., Stefanescu, C., \& Traveset, A. (2011b). Strong, long-term temporal dynamics of an ecological network. Plos One, 6, e26455.

Ollerton, J. (2006). "Biological barter": patterns of specialization compared across different mutualisms. In: Plant pollinator interactions: from specialization to generalization (eds. Waser, N. M \& Ollerton, J.). University of Chicago Press, Chicago.

Palmer, T.M., Stanton, M.L. \& Young, T.P. (2003). Competition and coexistence: exploring mechanisms that restrict and maintain diversity within mutualist guilds. American Naturalist, 162, S63-S79.

Pellmyr, O. (2003). Yuccas, yucca moths, and coevolution: a review. Annals of the Missouri Botanical Gardens, 90, 35-55.

Pires, M.M., Prado, P.I. \& Guimarães, P.R., Jr. (2011). Do food web models reproduce the structure of mutualistic networks? Plos One, 6, e27280.

Poisot, T., Stouffer, D. B. \& Gravel, D. (2015). Beyond species: why ecological interaction networks vary through space and time. Oikos (in press).

Raimundo, R.L.G., Gibert, J.P., Hembry, D.H. \& Guimarães, P.R., Jr. (2014). Conflicting selection in the course of adaptive diversification: the interplay between mutualism and intraspecific competition. American Naturalist, 183, 363-375.

Ramos-Jiliberto, R., Valdovinos, F. S., Moisset de Espanés, P., \& Flores, J. D. (2012). Topological plasticity increases robustness of mutualistic networks. Journal of Animal Ecology, 81, 896-904.

Ricciardi, F., Boyer, M. \& Ollerton, J. (2010). Assemblage and interaction structure of the anemonefish-anemone mutualism across the Manado region of Sulawesi, Indonesia. Environmental Biology of Fishes, 87, 333-347.

Sazima, C., Jordano, P., Guimarães Jr, P. R., Reis, S. F. dos, \& Sazima, I. (2012). Cleaning associations between birds and herbivorous mammals in Brazil: structure and complexity. The Auk, 129, 36-43.

Schleuning, M., Fründ, J., \& García, D. (2015). Predicting ecosystem functions from biodiversity and mutualistic networks: an extension of trait-based concepts to plant-animal interactions. Ecography, 38, 1-13.

Suweis, S., Simini, F., Banavar, J.R. \& Maritan, A. (2013). Emergence of structural and dynamical properties of ecological mutualistic networks. Nature, 500, 449-452.

Thébault, E., \& Fontaine, C. (2010). Stability of ecological communities and the architecture of mutualistic and trophic networks. Science, 329, 853-856.

Thompson, J. N. (2005). The geographic mosaic of coevolution. University of Chicago Press, Chicago. 
Thompson, J. N., Schwind, C., Guimarães, P. R. \& Friberg, M. (2013). Divergence through multitrait evolution in coevolving interactions. Proceedings of the National Academy of Sciences, 110, 11487-11492.

Vázquez, D.P., Blüthgen, N., Cagnolo, L. \& Chacoff, N.P.P. (2009). Uniting pattern and process in plant-animal mutualistic networks: a review. Annals of Botany, 103, 1445-1457.

Vizentin-Bugoni, J., Maruyama, P.K. \& Sazima, M. (2014). Processes entangling interactions in communities: forbidden links are more important than abundance in a hummingbird-plant network. Proceedings of the Royal Society B, 281, 20132397.

Warren, R.J., Giladi, I. \& Bradford, M.A. (2014). Competition as a mechanism structuring mutualisms. Journal of Ecology, 102, 486-495.

Williams, R.J. \& Martinez, N.D. (2008). Success and its limits among structural models of complex food webs. Journal of Animal Ecology, 77, 512-519.

Zhang, F., Hui, C. \& Terblanche, J.S. (2011). An interaction switch predicts the nested architecture of mutualistic networks. Ecology Letters, 14, 797-803. 
Table 1. Percentage of empirical low-intimacy mutualistic networks whose structural properties fall within the $95 \%$ most likely values of the corresponding structural properties computed for optimized model networks after long-term adaptive rewiring.

\begin{tabular}{lccc}
\hline \multicolumn{1}{c}{ Biological System } & $\begin{array}{c}\text { Interspecific } \\
\text { competition scenario }\end{array}$ & $\begin{array}{c}\text { Nestedness } \\
\text { (NODF) }\end{array}$ & $\begin{array}{c}\text { Modularity } \\
\text { (Q) }\end{array}$ \\
\hline Plant-Ant (PA) & CE & $100 \%$ & $50 \%$ \\
& CM & $100 \%$ & $0 \%$ \\
NC & $100 \%$ & $50 \%$ \\
Client-Cleaner (CC) & CE & $33 \%$ & $33 \%$ \\
& NC & $0 \%$ & $33 \%$ \\
Plant-Pollinator (PP) & NC & $33 \%$ & $33 \%$ \\
& & & \\
& CE & $56.2 \%$ & $56.2 \%$ \\
Plant-Seed Dispersers (PS) & NC & $50 \%$ & $43.7 \%$ \\
& & $50 \%$ & $56.2 \%$ \\
& CE & $69.2 \%$ & $76.9 \%$ \\
& CM & $76.9 \%$ & $53.8 \%$ \\
& NC & $69.2 \%$ & $76.9 \%$ \\
\hline
\end{tabular}




\section{FIGURE CAPTIONS}

Figure 1. The community dynamics model incorporates adaptive rewiring of mutualistic interactions. (A) Mutualistic interactions within the hypothetical community represented as a bipartite network from which one species (green) is randomly sampled. The sizes of the bars are proportional to the species abundances. (B) The new interaction pattern is retained if rewiring (bold green link) maximizes the local species abundance. The colored bars indicate changes in abundances. Hot colors indicate an increase in abundance after the interaction switch; cold colors indicate a decrease in abundance after the rewiring event; white bars indicate species whose abundances did not change. (C) The community matrix $\mathbf{T}$ representing animals $(A)$ and plants $(P)$ within a mutualistic assemblage. The matrix $\mathbf{T}$ has four quadrats (see eq. 1). Yellow quadrats depict mutualistic interactions $\left(\Gamma_{A P}\right.$ and $\left.\Gamma_{P A}\right)$. Blue quadrats describe competitive interactions $\left(\Omega_{A A}\right.$ and $\left.\Omega_{P P}\right)$. Diagonal elements representing intraspecific competition are also represented in blue. (D) A hypothetical matrix defined by $S_{P}=7$ plant species, $S_{A}=7$ animal species, $c=0.4, \sigma_{\Gamma}=\sigma_{\Omega}=0.3$. Hot colors represent mutualisms, and cold colors represent competitive interactions. The color gradients indicate weak (yellow/light blue) to strong (red/dark blue) effects of ecological interactions on species abundances.

Figure 2. General effects of adaptive rewiring on model mutualistic networks. (A) Adaptive rewiring leads to the emergence of structure in model networks, as demonstrated by the aggregated results from 30 simulations for each of the 44 mutualistic systems with the same dimensions and connectances as the natural mutualistic assemblages listed in Table S1. The prevalence of positive values of $\triangle N O D F$ (the difference between the degrees of nestedness of the final and initial networks) indicates increased nestedness. Similarly, the decrease in modularity is indicated by the prevalence of negative values of $\Delta Q$ - the difference between modularity degrees of the final and initial networks. (B) Relationship between the destabilizing effects of long-term adaptive rewiring and species richness (network size). Higher values of $\Delta \lambda_{\mathbb{R}}$ imply that the likelihood of stability decreased.

Figure 3. Structural fit between model mutualistic networks and their empirical counterparts with identical dimensions $\left(S_{M}\right.$ and $\left.S_{A}\right)$ and connectance (c). (A) Agreement between structural properties (nestedness and modularity) of 1,000 model networks (black dots) and the corresponding empirical mutualistic networks (red dots). The networks are summarized in Table S1 and cover a wide variety of mutualistic systems, including low-intimacy interactions between plants and the animals dispersing their seeds (PS), between plants and their animal pollinators, between cleaner species of fishes and shrimps and their client fishes (CC), and between plants with extrafloral nectaries and protective ants (AP). Other type of mutualisms include high-intimacy interactions between anemone fishes and their host sea anemones (AF) and between myrmecophyte plants and their associated ant species. The remaining panels depict the distributions of standardized errors summarizing the fit of the structural properties of empirical networks and their counterparts in the initial (probabilistic) networks and final (optimized) networks. (B) Standardized model errors in nestedness $\left(E_{N O D F}\right)$ for low- and highintimacy networks. (C) Standardized model errors in modularity $\left(E_{Q}\right)$ for low- and highintimacy networks. All results shown in this figure are for the baseline scenario assuming that species compete for resources external to mutualistic interactions (CE).

Figure 4. Distribution of normalized model errors (NME) for nestedness (A) and modularity (B) of 34 low-intimacy mutualistic networks under each interspecific competition scenario. The absolute NME values range between 0 and 1 and indicate whether the empirical property 
value is among the $95 \%$ most likely model property values. Results refer to 1,000 simulation replicates for each of 34 low-intimacy mutualistic networks. See Figure 3 for descriptions of the acronyms used in the abscissae.

Figure 5. Variation of structural properties (nestedness and modularity) and community stability $\left[\lambda_{\mathbb{R}(f)}\right]$ and the number of rewiring events under each of the interspecific competition scenarios modeled in this study. The results are from 1,000 simulation replicates using the following parameter values: $S_{M}=50 ; S_{A}=25 ; S_{P}=25 ; \sigma_{\Omega}=\sigma_{\Gamma}=0.054 ; c=0.174$. 
Figure 1

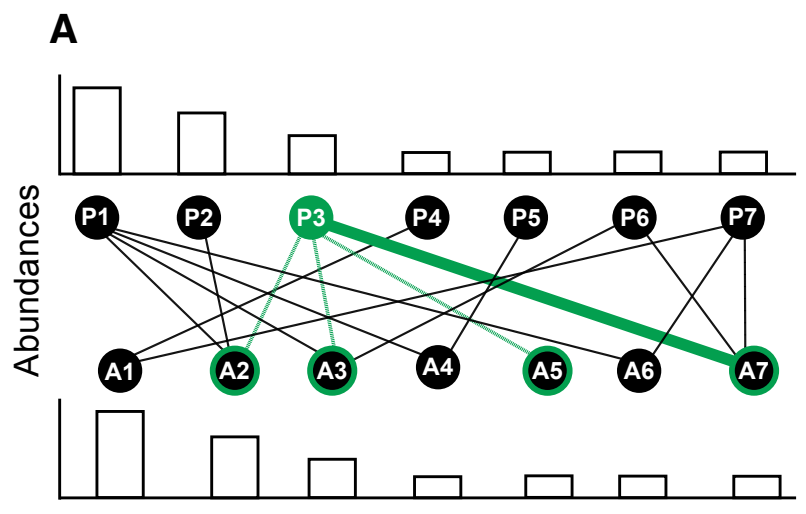

B
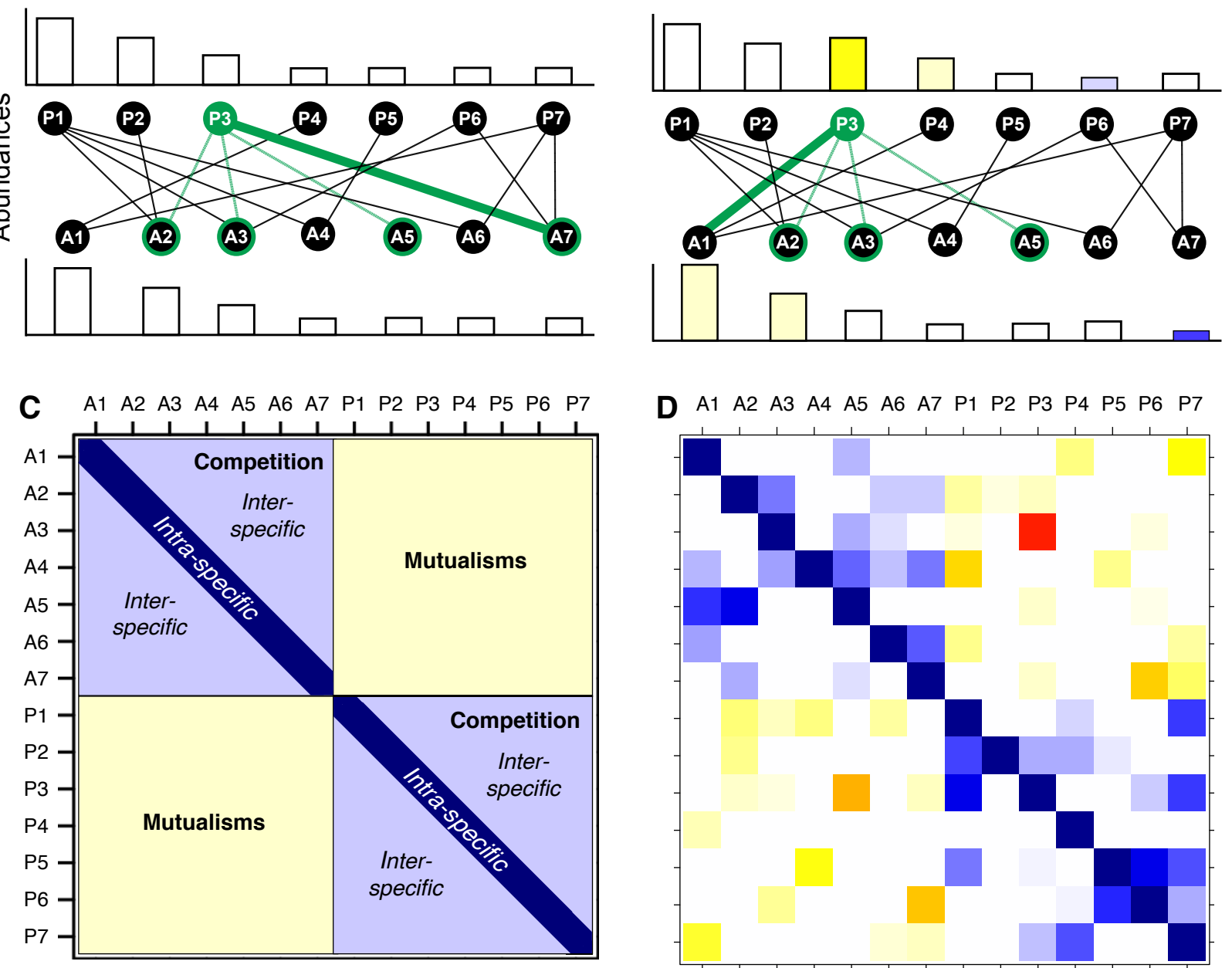

$\begin{array}{lllllllllllllllllllllllllllll}\text { D A1 } & \text { A2 } & \text { A3 } & \text { A4 } & \text { A5 } & \text { A6 } & \text { A7 } & \text { P1 } & \text { P2 } & \text { P3 } & \text { P4 } & \text { P5 } & \text { P6 } & \text { P7 }\end{array}$

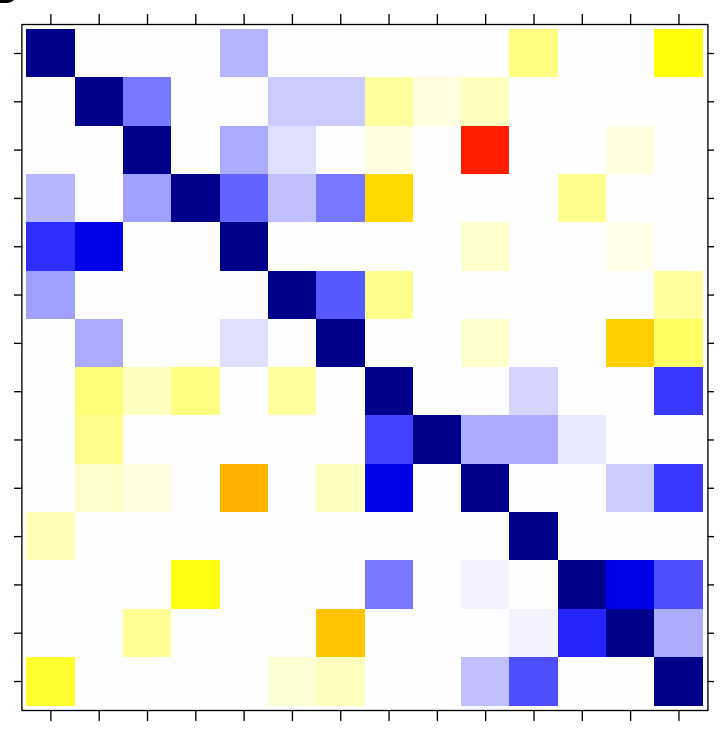


Figure 2
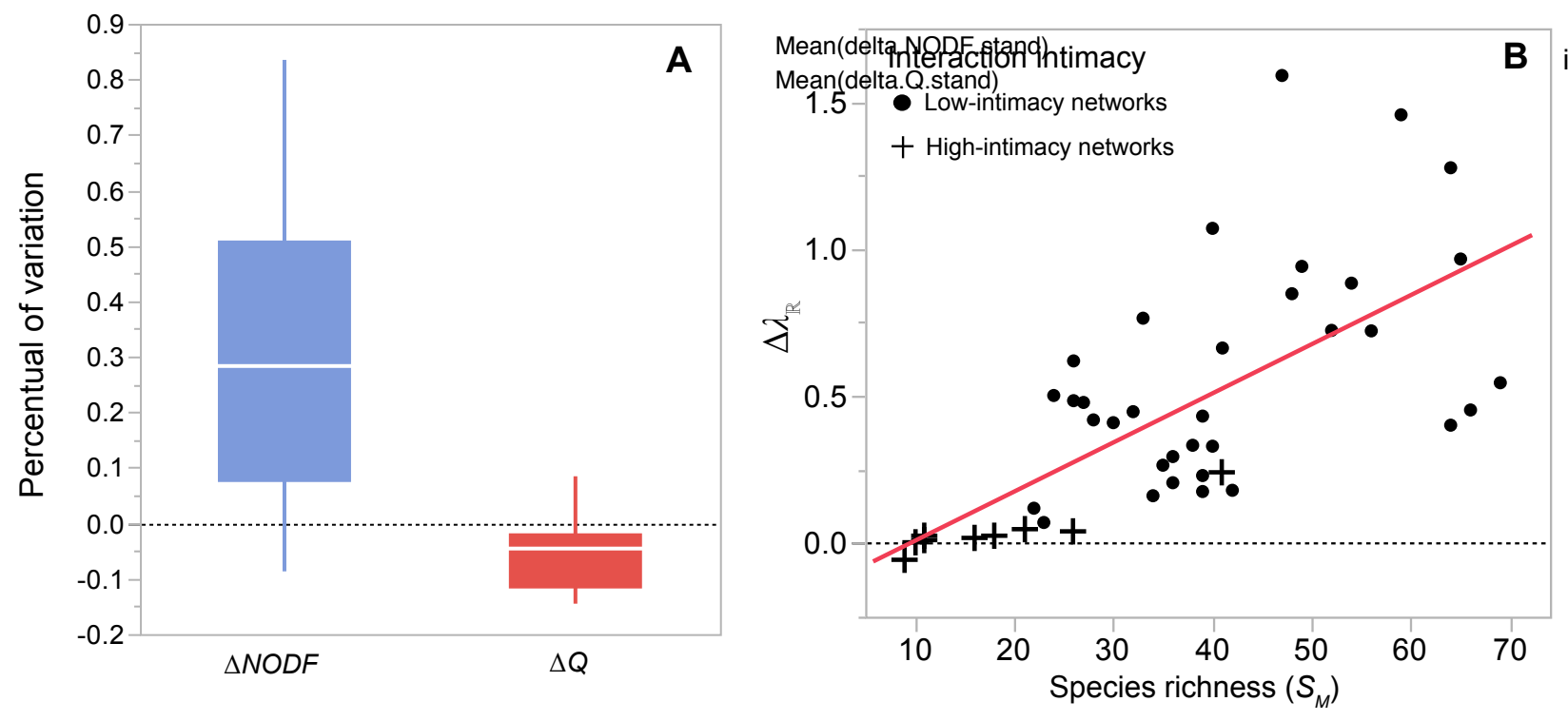


\section{Figure 3}
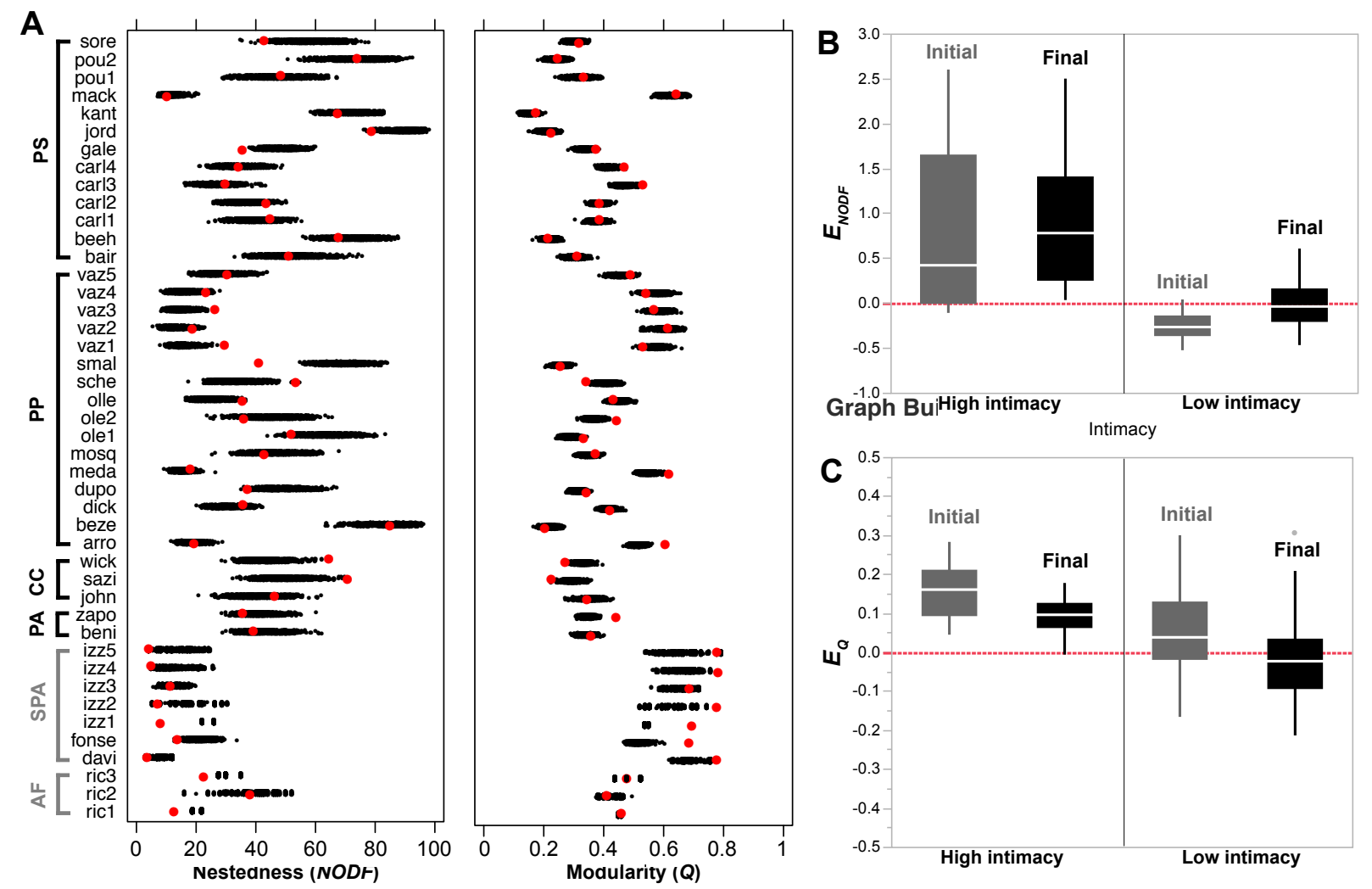


\section{Figure 4}
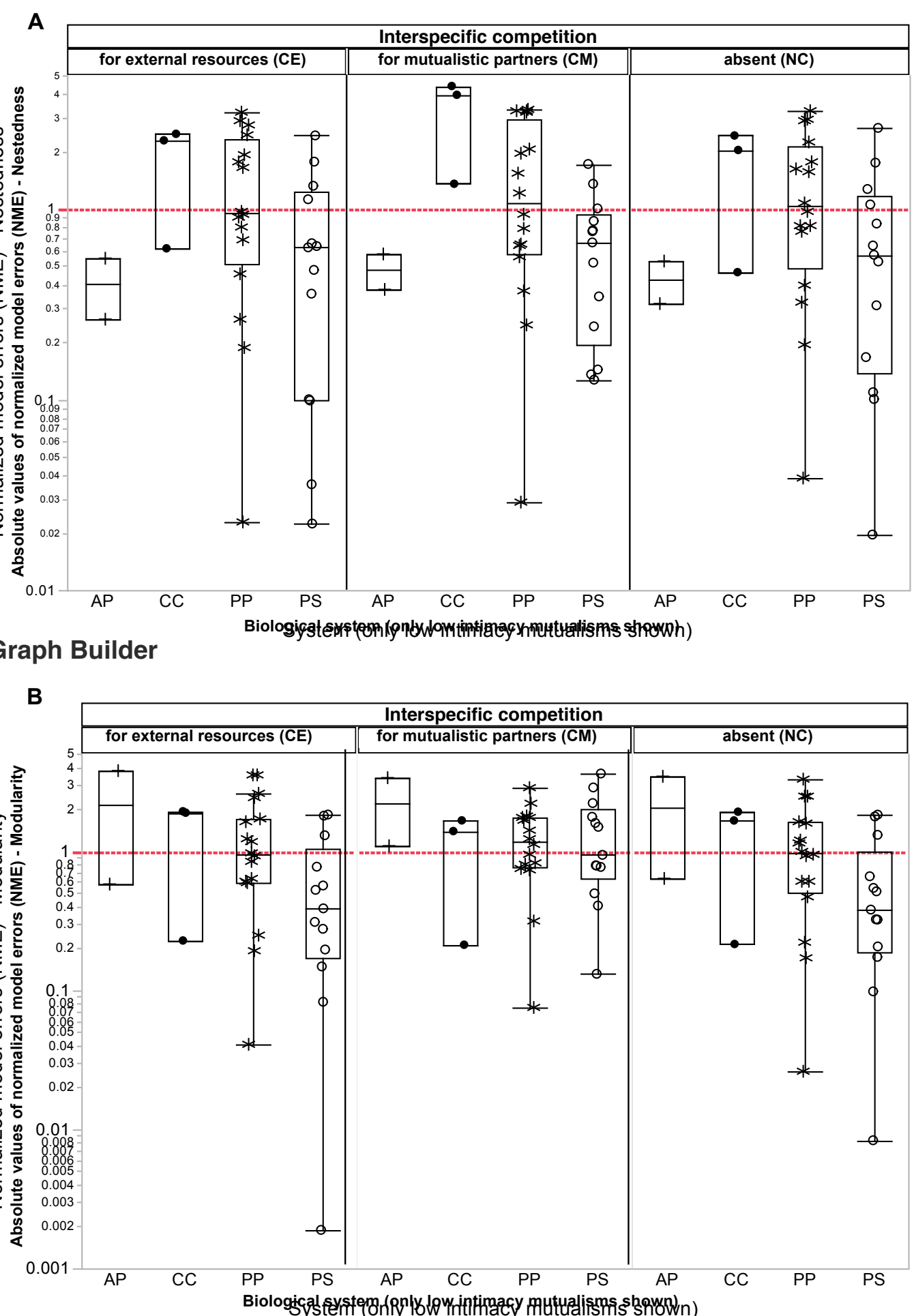


\section{Figure 5}

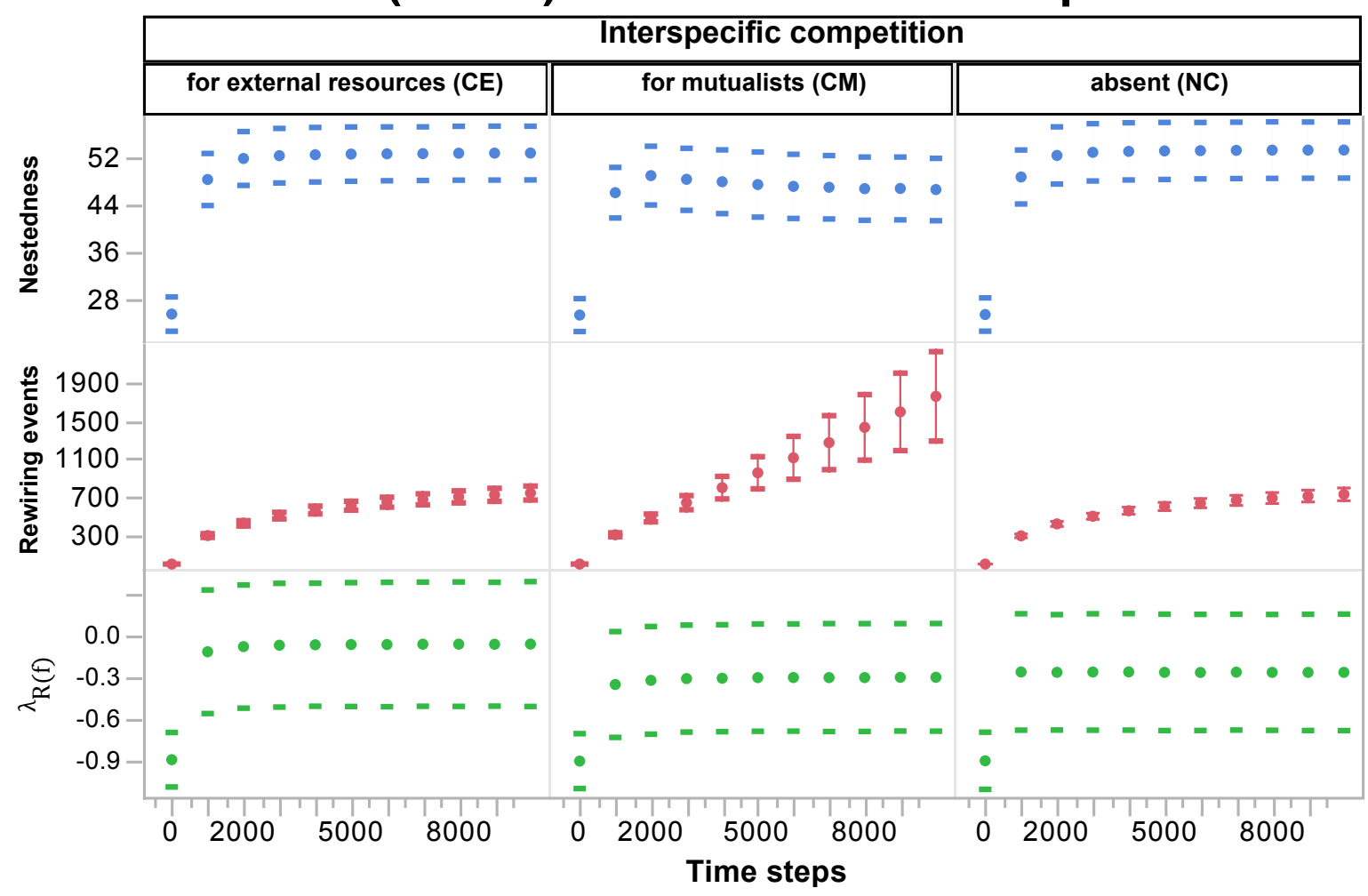




\title{
Supporting Material
}

\section{Does adaptive rewiring explain the structural variation \\ of mutualistic networks?}

\author{
Rafael L. G. Raimundo, Mathias M. Pires, Vinicius A. G. Bastazini, and \\ Paulo R. Guimarães Jr
}

Empirical data on mutualistic networks

Assumptions regarding natural selection

Asymptotic levels of nestedness

General properties of model mutualistic networks

Species richnesses, connectances, and emerging network properties 125 Species abundances and degrees (k)

Species abundance distributions and network properties

Effects of interspecific competition regimes on network properties 126

Stability and species abundances 126

Normalized model errors (NME) when only stable communities are considered .... 126

Mean interaction strength across interspecific competition scenarios 126

Consequences of strengthening per capita effects of interspecific competition 127

Temporal variation in species abundances 127

Structural fit between model and empirical low-intimacy networks 127

References cited in the Supporting Material 128 


\section{EMPIRICAL DATA ON MUTUALISTIC NETWORKS}

To explore the consequences of adaptive rewiring across mutualisms with diverse natural history attributes, we used data from 44 empirical networks depicting different types of mutualisms that are widely distributed among diverse ecogeographic regions (Table S1). Our dataset includes 34 low-intimacy mutualistic networks: 13 assemblages of zoochoric plants and the animals species dispersing their seeds, 16 assemblages of flowering plants and their animal pollinators, 3 marine cleaning mutualisms involving cleaner species of shrimps or fishes that remove ectoparasites and other material from their client fish species, and 2 generalized protection mutualisms between plants with extrafloral nectaries and ants. Our dataset also includes 10 high-intimacy mutualistic networks: 3 networks depicting obligate mutualisms between anemone fishes and their host sea anemones and 7 networks describing obligate mutualisms between ants and myrmecophyte plants. Most of the matrices listed in Table S1 are available on the Interaction Web Database (IWDB) website at https://www.nceas.ucsb.edu/interactionweb. Low- and high-intimacy empirical networks have contrasting structural properties and are characterized, respectively, by higher and lower degrees of nestedness (Fig. S1A), lower and higher degrees of modularity (Fig. S1B), lower and higher network species richnesses (Fig. S1C), and lower and higher median connectances, with low-intimacy networks exhibiting higher connectance variance (Fig. S1D).

\section{ASSUMPTIONS REGARDING NATURAL SELECION}

We assumed that natural selection favors interaction switches that maximize the abundance of a local species without considering the alternative algorithm of community-level optimization presented by Suweis et al. (2013). Community-level optimization was disregarded because it implies that group selection operates to shape ecological networks, i.e., interaction switches are fixed only if they increase the overall species abundances within the community. Because population-level optimization algorithms can reproduce the empirical structural properties of mutualistic networks (Zhang et al. 2011; Suweis et al. 2013; this study), we applied the parsimony principle to argue that community-level optimization cannot be regarded as a plausible mechanism explaining the emergence of structure in ecological networks. Community-level optimization prohibits the evolution of strategies leading to fitness gain if such strategies imply a reduction of the overall sum of all species abundances. However, a plausible mechanism for such an optimization scheme is not known. The known properties of 
natural populations and communities indicate that the organization of networks is more likely to be an outcome of selection acting on individuals within populations. Population-level optimization is supported by the classical theory that connects population biology to the fitness concept, describing how new genes or traits increase in prevalence within the population if their associated intrinsic growth rates are higher than the average of the population.

\section{ASYMPTOTIC LEVELS OF NESTEDNESS}

The number of time steps of $T=100 S_{M}^{3 / 2}$, in which $S_{M}$ is the total number of species within the mutualistic network, ensures that $95 \%$ of the rewiring attempts will be rejected and that the network can be considered optimized (Suweis et al. 2013). To determine if $T$ was sufficient to ensure that the structural properties reach asymptotic levels in our implementation of the model, we ran 1,000 simulations considering a hypothetical assemblage of $S_{M}=50$ species $\left(S_{A}=25\right.$ and $\left.S_{P}=25\right)$ and recorded the values of nestedness $(N O D F)$ at each time step until $T$ was reached. The results, shown in Fig. S2, assume that mutualistic species compete for resources external to mutualistic interactions (scenario $\mathrm{CE}$ ). In every simulation, nestedness reached asymptotic levels before $25 \%$ of the $T$ time steps, with no subsequent oscillations. A wide variety of final nestedness values result from model networks starting with the same parameterization, revealing that multiple possible optimization trajectories exist in which equilibrium points drive structural evolution toward increased nestedness. Similar asymptotic levels were observed when other underlying interspecific competition regimes were assumed (scenarios $\mathrm{CM}$ and $\mathrm{NC}$, results not shown).

\section{GENERAL PROPERTIES OF MODEL MUTUALISTIC NETWORKS}

We used mean values of the standardized measures of variation in network properties, $\triangle N O D F, \Delta Q$, and $\Delta \lambda_{\mathbb{R}}$, to perform the single-variable regressions among network species richness and connectances, which are predictors of structural variation $(\triangle N O D F$ and $\triangle \mathrm{Q})$ and are also among the predictors (network species richness, connectances, $N O D F$ or $\triangle Q$ ) of community stability variation $\left(\Delta \lambda_{\mathbb{R}}\right)$. Coefficients of determination $\left(R^{2}\right)$ were used to compare goodness-of-fit among different potential predictors (James et al. 2012). The values of NODF and $Q$ correspond to median values obtained for 30 simulations for each of 44 networks 
parameterized with dimensions and connectances identical to those described in Table S1.

Species richnesses, connectances, and emerging network properties. The variation in nestedness arising from adaptive rewiring $(\triangle N O D F)$ was not explained by species richness $\left(S_{M} ; R^{2}=0.08 ; P=0.09\right)$ and connectance $\left(c ; R^{2}=0.02 ; P=0.33 ;\right.$ Fig. S3A-B $)$. The modularity variation, $\Delta Q$, was positively related to network connectance $\left(R^{2}=0.28 ; P<\right.$ $0.001)$ but not species richness $\left(R^{2}=0.01 ; P=0.48\right.$; see Fig. S3C-D). Finally, stability variation $\left(\Delta \lambda_{\mathbb{R}}\right)$ was positively affected by network species richness $\left(S_{M}, R^{2}=0.45 ; P<\right.$ $0.0001)$ but not connectance $\left(R^{2}=0.005 ; P=0.63\right.$; see Fig. S3E-F).

Species abundances and degree (k). We performed 1,000 simulation replicates to investigate the relationship between species abundance and degree ( $k$, the number of mutualistic partners a species have) over time. In optimized networks, species degrees $(k)$ can be mostly explained in terms of final species abundances $\left(R^{2}=0.596 ; P<0.0001\right.$; Fig. S4A $)$. Overall, species acquiring more links become more abundant over time $\left(R^{2}=0.324, P<\right.$ 0.0001; Fig. S4B), but the initial species abundances are not related to final species degrees $\left(R^{2}=0.009, P=0.585\right.$; Fig. S4C) or final species abundances $\left(R^{2}=0.0001, P=0.99\right.$; Fig. $\mathrm{S} 4 \mathrm{D})$. The increased nestedness that emerges via adaptive rewiring thus leads to changes in species roles within the network and affects relative species abundances, but the highly connected species in the final networks do not correspond to the species with higher degrees $(k)$ in the initial networks $\left(R^{2}=0.01, P=0.49\right)$.

\section{SPECIES ABUNDANCE DISTRIBUTIONS AND NETWORK PROPERTIES}

We compared the consequences of the initial species abundances distributions for network properties under two different assumptions. The first assumption was that the initial distributions are uniform. Therefore, the initial networks are assembled randomly, and all species pairs have the same probability of interaction. Alternatively, the second scenario assumes that abundances within $A$ and $P$ follow lognormal distributions $(\mu=1 ; \sigma=0.5)$. The probability of interaction $P_{(i, j)}$ for any given pair of species is thus the product of their abundances. Network connectance $(c)$ was held constant in both scenarios. The mean nestedness in optimized networks was higher under lognormal initial species distributions (Fig. S5A) than in the scenario assuming uniform initial species distributions. However, final networks were more stable when the optimization process departed from uniform species abundance distributions than when initial species abundances were sampled from lognormal 
distributions (Fig. S5B).

\section{EFFECTS OF INTERSPECIFIC COMPETITION SCENARIOS ON NETWORK PROPERTIES}

We performed complementary simulations exploring the effects on community stability imposed by three interspecific competition scenarios. These scenarios contrast biologically plausible conditions in which species (i) compete for resources external to mutualistic interactions (external resource competition scenario, CE); (ii) compete for mutualistic partners (competition for mutualists scenario, CM); or (iii) are not affected by any type of interspecific competition (scenario NC). Detailed descriptions for the implementation of each interspecific competition scenario can be found in the Methods section (main text). Unless otherwise indicated, the results correspond to simulations in which $S_{M}=50$ (species richness or network size); $S_{A}=25$ (number of species within set $A$ ); $S_{P}=25$ (number of species within set $P$ ); $\sigma_{\Omega}=\sigma_{\Gamma}=0.054$ [standard deviation of per capita effects of mutualism $\left(\gamma_{i j}\right.$ and $\left.\gamma_{j i}\right)$ and interspecific competition $\left(\omega_{i j}\right.$ and $\left.\omega_{j i}\right)$, respectively]; $c=0.174$ [mutualistic network connectance; for the scenario in which species compete for external resources (NC), the competition matrices corresponding to quadrats $\Omega_{A A}$ and $\Omega_{P P}$ of matrix $\mathbf{T}$ (eq. 2 and Fig. 1, main text) have the same connectance].

Stability and species abundances. We used data from the final networks of 1,000 simulation replicates/interspecific competition scenario to describe the abundances of the rarest species as $\lambda_{\mathbb{R}(f)}$ approaches zero (and communities become unstable), and no qualitative difference was detected among different interspecific competitions scenarios (fig. S6).

Normalized model errors (NME) when only stable communities are considered. Complementary analysis using normalized model errors (see Methods and Fig. 4, main text) was conducted to evaluate the goodness of fit between the structural properties of model and empirical networks when only stable communities [i.e., those with $\lambda_{\mathbb{R}(f)}<0$ ] are considered. The percentages of unstable final networks varied between interspecific competition scenarios, with $13.8 \%, 8.6 \%$, and $9.4 \%$ characterized by $\lambda_{\mathbb{R}(\mathrm{f})}>0$ in $\mathrm{CE}, \mathrm{CM}$, and $\mathrm{NC}$, respectively. Comparison of Fig. 4 (main text) and Fig. S7 (below) reveals that exclusion of unstable networks does not produce qualitatively distinct results with regards to the structural fit between empirical and model networks.

Mean interaction strength across interspecific competition scenarios. We compared 
mean competitive interaction strengths between competition scenarios by conducting 1,000 simulation replicates through 10,000 time steps and computing, at every 1,000 time steps, the mean interspecific competition strength within each species set $(A$ and $P$ ). Distinct interspecific competition scenarios impose different mean interaction strengths, which are stronger when species compete for external resources (scenario CE) than under competition for mutualistic partners (scenario CM) (Fig. S8).

Consequences of strengthening per capita effects of interspecific competition. We examined whether increasing the per capita effects of interspecific competition $\left(\omega_{i j}\right.$ and $\left.\omega_{j i}\right)$ would affect the emerging properties of model mutualistic networks. To simulate more intense strengths of interspecific competition, we multiplied quadrats $\Omega_{A A}$ and $\Omega_{P P}$ of matrix $\mathbf{T}$ (eq. 2, main text) by progressively higher values of a constant $\alpha(1,5,10,20)$. We performed 1,000 simulation replicates for each $\alpha$ value. Under higher $\alpha$, the final nestedness decreased, modularity increased, and mutualistic assemblages became progressively more likely to be unstable (Fig. S9).

Temporal variation in species abundances. We performed 1,000 simulation replicates for each interspecific competition scenario (CE, CM, and NC) to explore the potential effects on temporal variation in species abundances. Initial relative species abundances were sampled from lognormal distributions with mean $(\mu)=1$ and standard deviation $(\sigma)=0.5$. Simulations were performed for $T=100 S_{M}^{3 / 2}$ time steps. The mean species abundances were higher when interspecific competition was absent (scenario NC), intermediate when competition was related to external resources (scenario $\mathrm{CE}$ ), and lower when species were in competition for mutualistic partners (Fig. S10).

\section{STRUCTURAL FIT BETWEEN MODEL AND EMPIRICAL LOW-INTIMACY NETWORKS}

Fig. S11 presents complementary results for the accuracies of the initial (probabilistic) and final (optimized) model networks in reproducing structural properties for each low-intimacy (Table S1). We built standardized error measures for each structural property (nestedness or modularity) and network (initial or final) defined as $E_{P(t)}=P_{t}-P_{N} / P_{N}$, where $P \in\{N O D F, Q\}, \mathrm{t} \in\{i, f\}$, and $P_{N}$ refers to the empirical property values observed in networks of identical dimensions and connectances (see the main text for more details). Model structural properties correspond to median values from 30 simulation replicates per network. 


\section{REFERENCES CITED IN THE SUPPORTING MATERIAL}

Arroyo, M.T.K., Primack, R. \& Armesto, J. (1982). Community studies in pollination ecology in the high temperate Andes of central Chile. I. Pollination mechanisms and altitudinal variation. American Journal of Botany, 69, 82-97.

Baird, J.W. (1980). The selection and use of fruit by birds in an eastern forest. The Wilson Bulletin, 92,63-73.

Beehler, B. (1983). Frugivory and polygamy in birds of paradise. The Auk, 100, 1-12.

Bezerra, E.L.S., Machado, I.C. \& Mello, M.A.R. (2009). Pollination networks of oil-flowers: a tiny world within the smallest of all worlds. Journal of Animal Ecology, 78, 1096-1101.

Carlo, T., Collazo, J.A. \& Groom, M.J. (2003). Avian fruit preferences across a Puerto Rican forested landscape: pattern consistency and implications for seed removal. Oecologia, 134, $119-131$.

Davidson, D., Snelling, R. \& Longino, J. (1989). Competition among ants for myrmecophytes and the significance of plant trichomes. Biotropica, 21, 64-73.

Dicks, L.V., Corbet, S.A. \& Pywell, R.F. (2002). Compartmentalization in plant-insect flower visitor web. Journal of Animal Ecology, 71, 32-43.

Dupont, Y. \& Hansen, D. (2003). Structure of a plant-flower-visitor network in the highaltitude sub-alpine desert of Tenerife, Canary Islands. Ecography, 26, 301-310.

Fonseca, C.R. \& Ganade, G. (1996). Asymmetries, compartments and null Interactions in an Amazonian ant-plant community. Journal of Animal Ecology, 65, 339-347.

Galetti, M. \& Pizo, M. (1996). Fruit eating by birds in a forest fragment in Southeastern Brazil. Ararajuba, 4, 71-79.

Guimarães, P.R., Jr, Rico-Gray, V., Oliveira, P.S., Izzo, T.J., Reis, Dos, S.F.F. \& Thompson, J.N. (2007a). Interaction intimacy affects structure and coevolutionary dynamics in mutualistic networks. Current Biology, 17, 1797-1803.

Guimarães, P.R., Jr, Sazima, C., Reis, Dos, S.F.F. \& Sazima, I. (2007b). The nested structure of marine cleaning symbiosis: is it like flowers and bees? Biology Letters, 3, 51-54.

James, A., Pitchford, J.W. \& Plank, M.J. (2012). Disentangling nestedness from models of ecological complexity. Nature, 487, 227-230.

Johnson, W.S. \& Ruben, P. (1988). Cleaning behavior of Bodianus rufus, Thalassoma bifasciatum, Gobiosoma evelynae, and Periclimenes pedersoni along a depth gradient at Salt River Submarine Canyon, St. Croix. Environmental Biology of Fishes, 23, 225-232.

Jordano, P. (1985). El ciclo anual de los paseriformes frugívoros en el matorral mediterráneo del sur de España: importancia de su invernada y variaciones interanuales. Ardeola, 32, 6994. 
Kantak, G.E. (1979). Observations on some fruit-eating birds in Mexico. The Auk, 96, 183186.

Mack, A.L. (1994). Notes on the nests and eggs of some birds at the Crater Mountain Research Station, Papua New Guinea. Bulletin of the British Ornithologists' Club, 114, 176181.

Medan, D., Montaldo, N., Devoto, M., Mantese, A., Vasellati, V. \& Bartoloni, N. (2002). Plant-pollinator relationships at two altitudes in the Andes of Mendoza, Argentina. Arctic, Antarctic, and Alpine Research, 34, 233-241.

Mosquin, T., Martin, J.E.H. \& Martin, J. (1967). Observations on the pollination biology of plants on Melville Island, NWT, Canada. Canadian Field Naturalist 81, 201-205.

Olesen, J., Eskildsen, L.I. \& Venkatasamy, S. (2002). Invasion of pollination networks on oceanic islands: importance of invader complexes and endemic super generalists. Diversity and Distributions, 8, 181-192.

Ollerton, J., Johnson, S.D., Cranmer, L. \& Kellie, S. (2003). The pollination ecology of an assemblage of grassland asclepiads in South Africa. Annals of Botany, 92, 807-834.

Poulin, B., Poulin, B., Wright, S.J., Wright, S.J., Lefebvre, G., Lefebvre, G., et al. (1999). Interspecific synchrony and asynchrony in the fruiting phenologies of congeneric birddispersed plants in Panama. Journal of Tropical Ecology, 15, 213-227.

Ricciardi, F., Boyer, M. \& Ollerton, J. (2010). Assemblage and interaction structure of the anemonefish-anemone mutualism across the Manado region of Sulawesi, Indonesia. Environmental Biology of Fishes, 87, 333-347.

Schemske, D.W., Wilson, M.F., Melampy, M.N., Miller, L.J., Verner, L., Schemske, K.M., et al. (1977). Flowering ecology of some spring woodland herbs. Ecology, 59, 351-366.

Small, E. (1976). Insect pollinators of the Mer Bleue peat bog of Ottawa. Canadian Field Naturalist, 90, 22-28.

Sorensen, A.E. (1981). Interactions between birds and fruit in a temperate woodland. Oecologia, 50, 242-249.

Suweis, S., Simini, F., Banavar, J.R. \& Maritan, A. (2013). Emergence of structural and dynamical properties of ecological mutualistic networks. Nature, 500, 449-452.

Vázquez, D.P. \& Simberloff, D. (2003). Changes in interaction biodiversity induced by an introduced ungulate. Ecology Letters, 6, 1077-1083.

Wicksten, M.K. (1998). Behaviour of cleaners and their client fishes at Bonaire, Netherlands Antilles. Journal of Natural History, 32, 13-30.

Zhang, F., Hui, C. \& Terblanche, J.S. (2011). An interaction switch predicts the nested architecture of mutualistic networks. Ecology Letters, 14, 797-803. 
Table S1. Natural mutualistic networks used to parameterize and evaluate the simulations. (PS) Mutualisms between plants and the animals that disperse their seeds. (PP) Mutualisms between animal pollinators and flowering plants. (CC) Marine mutualisms between cleaner species and their fish clients. (PA) Mutualisms between plants with extrafloral nectaries and protective ants. (AF) Obligate marine mutualisms between cleaner species of fishes and shrimps and their client fishes. (SPA) Protection mutualisms between myrmecophyte plants and ants. (L) Low-intimacy mutualisms. (H) High-intimacy mutualisms.

\begin{tabular}{|c|c|c|c|c|}
\hline Network & $\begin{array}{c}\text { System } \\
\text { (Intimacy) }\end{array}$ & Locality & Country & Reference \\
\hline sore & PS (L) & Oxford & United Kingdom & Sorensen 1981 \\
\hline pou2 & PS (L) & Soberania Park & Panama & Poulin et al. 1999 \\
\hline pou1 & PS (L) & Barro Colorado Island & Panama & Poulin et al. 1999 \\
\hline mack & PS (L) & CMBR Station & Papua New Guinea & Mack 1994 \\
\hline kant & PS (L) & Xpujil & Mexico & Kantak 1979 \\
\hline jord & PS (L) & Hato Raton & Spain & Jordano 1985 \\
\hline gale & PS (L) & Campinas & Brazil & Galetti \& Pizo 1996 \\
\hline carl4 & PS (L) & Fronton & Puerto Rico & Carlo et al. 2003 \\
\hline $\operatorname{carl3}$ & PS (L) & Cordillera & Puerto Rico & Carlo et al. 2003 \\
\hline $\operatorname{carl} 2$ & PS (L) & Cialitos & Puerto Rico & Carlo et al. 2003 \\
\hline carl1 & PS (L) & Caguana & Puerto Rico & Carlo et al. 2003 \\
\hline beeh & PS (L) & Mount Missi & Papua New Guinea & Beehler 1983 \\
\hline bair & PS (L) & Princeton & USA & Baird 1980 \\
\hline vaz5 & PP (L) & Quetrihue & Argentina & Vázquez \& Simberloff 2003 \\
\hline vaz4 & PP (L) & Mascardi & Argentina & Vázquez \& Simberloff 2003 \\
\hline vaz3 & PP (L) & Llao Llao & Argentina & Vázquez \& Simberloff 2003 \\
\hline vaz2 & $\mathrm{PP}(\mathrm{L})$ & Cerro Lopez & Argentina & Vázquez \& Simberloff 2003 \\
\hline vaz1 & PP (L) & Arroyo Goye & Argentina & Vázquez \& Simberloff 2003 \\
\hline smal & $\mathrm{PP}(\mathrm{L})$ & Dolman Ridge Road & Canada & Small 1976 \\
\hline sche & $\mathrm{PP}(\mathrm{L})$ & Brownfield Woods & USA & Schemske et al. 1977 \\
\hline olle & PP (L) & Wahroonga & South Africa & Ollerton et al. 2003 \\
\hline ole1 & PP (L) & Aigrettes Island & Mauritius & Olesen et al. 2002 \\
\hline ole2 & $\mathrm{PP}(\mathrm{L})$ & Flores Island & Portugal & Olesen et al. 2002 \\
\hline $\operatorname{mosq}$ & $\mathrm{PP}(\mathrm{L})$ & Melville Island & Canada & Mosquin et al. 1967 \\
\hline meda & $\mathrm{PP}(\mathrm{L})$ & Rio Blanco & Argentina & Medan et al. 2002 \\
\hline dupo & $\mathrm{PP}(\mathrm{L})$ & Tenerife & Spain & Dupont \& Hansen 2003 \\
\hline dick & $\mathrm{PP}(\mathrm{L})$ & Norfolk & United Kingdom & Dicks et al. 2002 \\
\hline beze & $\mathrm{PP}(\mathrm{L})$ & Catimbau Park & Brazil & Bezerra et al. 2009 \\
\hline arroyo 1 & PP (L) & Cordón del Cepo & Chile & Arroyo et al. 1982 \\
\hline wick & $\mathrm{CC}(\mathrm{L})$ & Bonaire & Netherlands Antilles & Wicksten 1998 \\
\hline sazi & $\mathrm{CC}(\mathrm{L})$ & Abrolhos & Brazil & Guimarães et al. 2007b \\
\hline john & $\mathrm{CC}(\mathrm{L})$ & Saint Crox & Virgin Islands & Johnson \& Ruben 1988 \\
\hline zapo & PA (L) & Valle de Zapotitlan & Mexico & Guimarães et al. 2007a \\
\hline beni & PA (L) & San Benito & Mexico & Guimarães et al. 2007a \\
\hline ric1 & $\mathrm{AF}(\mathrm{H})$ & Bahowo & Indonesia & Ricciardi et al. 2010 \\
\hline
\end{tabular}


Table S1 (continued).

\begin{tabular}{lllll} 
ric2 & AF $(\mathrm{H})$ & Tanjung Kopi & Indonesia & Ricciardi et al. 2010 \\
ric3 & AF $(\mathrm{H})$ & Tanjung Pisok & Indonesia & Ricciardi et al. 2010 \\
izz1 & SPA $(\mathrm{H})$ & Amazonas & Brazil & Guimarães et al. 2007a \\
izz2 & SPA $(\mathrm{H})$ & Amazonas & Brazil & Guimarães et al. 2007a \\
izz3 & SPA $(\mathrm{H})$ & Amazonas & Brazil & Guimarães et al. 2007a \\
izz4 & SPA $(\mathrm{H})$ & Amazonas & Brazil & Guimarães et al. 2007a \\
izz5 & SPA $(\mathrm{H})$ & Amazonas & Brazil & Guimarães et al. 2007a \\
fonse & SPA $(\mathrm{H})$ & Manaus & Brazil & Fonseca \& Ganade 1996 \\
davi & SPA $(\mathrm{H})$ & Manu Park & Peru & Davidson et al. 1989 \\
\hline
\end{tabular}




\section{SUPPLEMENTARY FIGURE CAPTIONS}

Figure S1. Structural properties of the 34 low-intimacy and 10 high-intimacy mutualistic networks used in this study (see also Table S1): (A) nestedness $(N O D F),(\mathbf{B})$ modularity $(Q)$, (c) species richness $\left(S_{M}\right)$ and (D) connectances $(c)$.

Figure S2. Temporal variation of nestedness $(N O D F)$ across $T=100 S_{M}^{3 / 2}$ time steps, in which $S_{M}$ is network species richness, for a total of 1,000 simulation replicates assuming $S_{M}=$ $50\left(S_{A}=25\right.$ and $\left.S_{P}=25\right)$. Other parameters used in these simulations are $\sigma_{\Omega}=\sigma_{\Gamma}=0.054$ and $c=0.174$. Temperature colors indicate point density and vary from low (cold colors) to high (hot colors).

Figure S3. Single-variable regression plots between network species richnesses or connectances, used here as predictors of the structural variation $(\triangle N O D F$ and $\triangle \mathrm{Q})$ and dynamic properties $\left(\Delta \lambda_{\mathbb{R}}\right)$ of optimized mutualistic networks. Each point corresponds to the mean value of 30 simulation replicates for each of the networks described in Table S1.

Figure S4. Relationship between species abundance and degree (number of links) in an initial, probabilistic network and a final, optimized network. The panels show regression plots for (A) final species degrees and final species abundances, (B) variation in species abundance and degree between initial and final networks, $(\mathbf{C})$ final and initial species abundances, and (D) final species degrees and initial species abundances. $S_{M}=33 ; S_{A}=25 ; S_{P}=25 ; \sigma_{\Omega}=\sigma_{\Gamma}=$ $0.054 ; c=0.44$.

Figure S5. Relationship between nestedness and stability in final, optimized model mutualistic networks emerging by adaptive rewiring assuming (A) uniform initial species abundance distributions or (B) lognormal initial species abundance distributions. The plots show the point density for 1,000 simulations per scenario, ranging from low point density (lighter areas) to high point density (darker areas). $S_{M}=50 ; S_{A}=25 ; S_{P}=25 ; \sigma_{\Omega}=\sigma_{\Gamma}=0.054$; $c=0.174$.

Figure S6. Stability of mutualistic assemblages under different interspecific competition regimes. Each panel represents a competition scenario with results from 1,000 simulation replicates showing the relationship between the abundance of the rarest species and the value

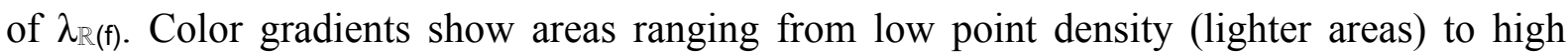
point density (darker areas). $S_{M}=50 ; S_{A}=25 ; S_{P}=25 ; \sigma_{\Omega}=\sigma_{\Gamma}=0.054 ; c=0.174$.

Figure S7. Structural fit between model and empirical networks when only stable communities are considered. The figure shows the distribution of normalized model errors (NME) for nestedness (A) and modularity (B) of 34 low-intimacy mutualistic networks under each interspecific competition scenario, considering only those communities for which $\lambda_{\mathbb{R}(f)}<$ 0 . Absolute NME values between 0 and 1 indicate that the empirical property value is within the $95 \%$ most likely model property values.

Figure S8. Mean strength of interspecific competition under the different interspecific competition regimes modeled in this study. Boxplots represent the distributions of the mean interspecific competition strengths affecting species within sets $A$ (blue boxes) and $P$ (red boxes). Results are from 1,000 simulation replicates using the following parameter values: $S_{M}$ $=50 ; S_{A}=25 ; S_{P}=25 ; \sigma_{\Omega}=\sigma_{\Gamma}=0.054 ; c=0.174$. 
Figure S9. Variation of structural properties (nestedness and modularity) and community stability $\left[\lambda_{\mathbb{R}(f)}\right]$ under increasing values of the per capita effects of interspecific competition. The constant $\alpha$ multiplies the interspecific competition quadrats, $\Omega_{A A}$ and $\Omega_{P P}$, in matrix $\mathbf{T}$ (see eq. 2 in the main text). Results are from 1,000 simulation replicates under the following parameterization: $S_{M}=50 ; S_{A}=25 ; S_{P}=25 ; \sigma_{\Omega}=\sigma_{\Gamma}=0.054 ; c=0.174$.

Figure S10. Temporal variation of species abundances for each of the three interspecific competition regimes modeled in this study. Initial relative species abundances are sampled from lognormal distributions with mean $(\mu)=1$ and standard deviation $(\sigma)=0.5$. (A) The panels in the top line show individual species abundances through time, with black lines representing species within set $A$ and red lines showing species within set $P$. The panels in the bottom line show temporal variation of mean species abundance within an assemblage. (B) Distributions of mean species abundances of optimized networks for 1,000 simulation replicates per interspecific competition scenario. $S_{M}=50 ; S_{A}=25 ; S_{P}=25 ; \sigma_{\Omega}=\sigma_{\Gamma}=0.054 ; c$ $=0.174$.

Figure S11. Observed deviations between structural properties of initial, probabilistic networks (blue) and final, optimized networks (red) for 34 low-intimacy networks. The model structural properties correspond to median values obtained from 30 simulation replicates per network. The following low-intimacy mutualistic systems are represented: (AP) mutualisms between plants with extrafloral nectaries and protective ants; (CC) mutualisms between cleaner species of fishes and shrimps and their client fish species; (PP) mutualisms between flowering plants and their animal pollinators; (PS) mutualisms between plants and animals dispersing their seeds. 
Figure S1
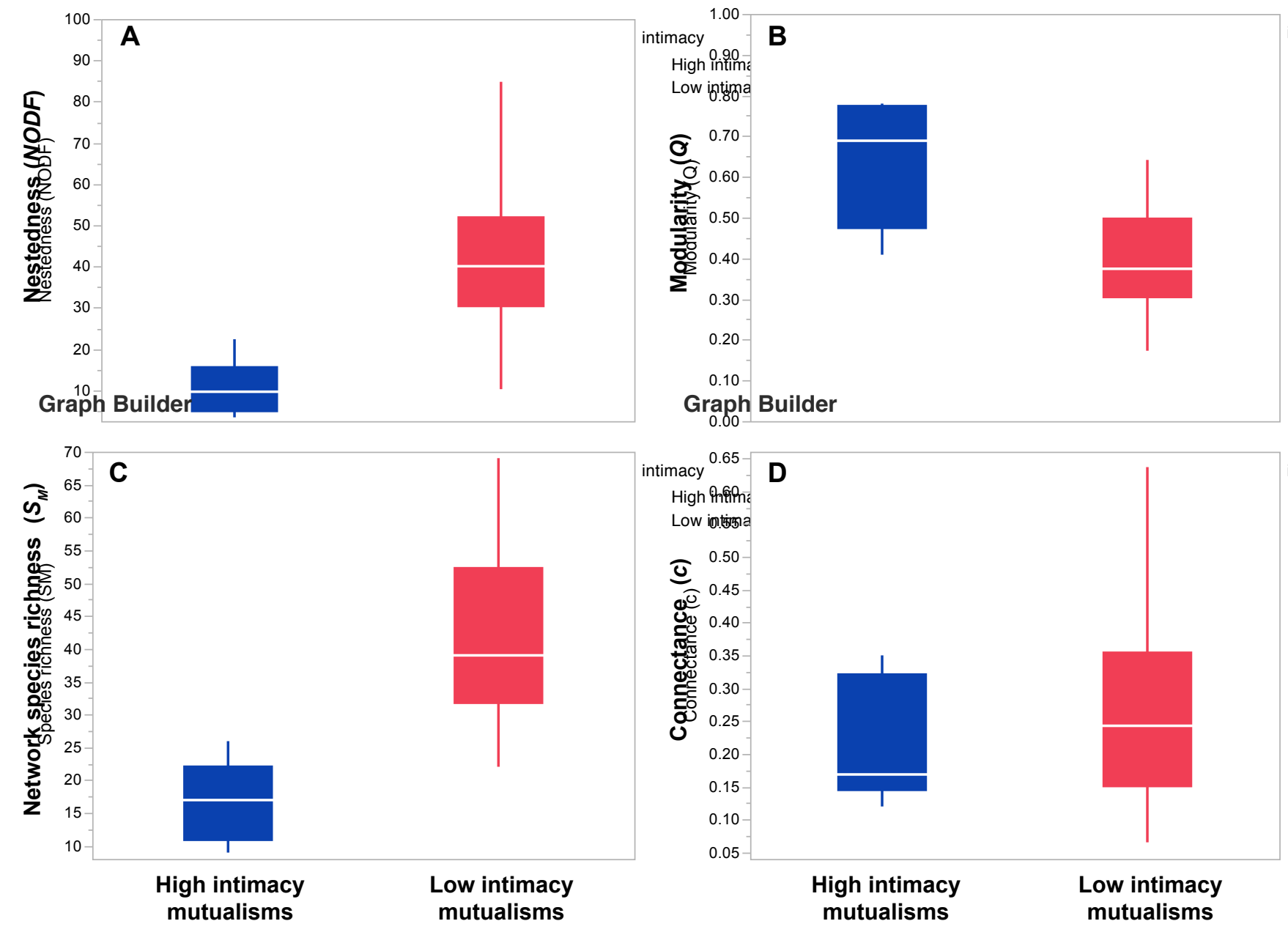
Figure S2

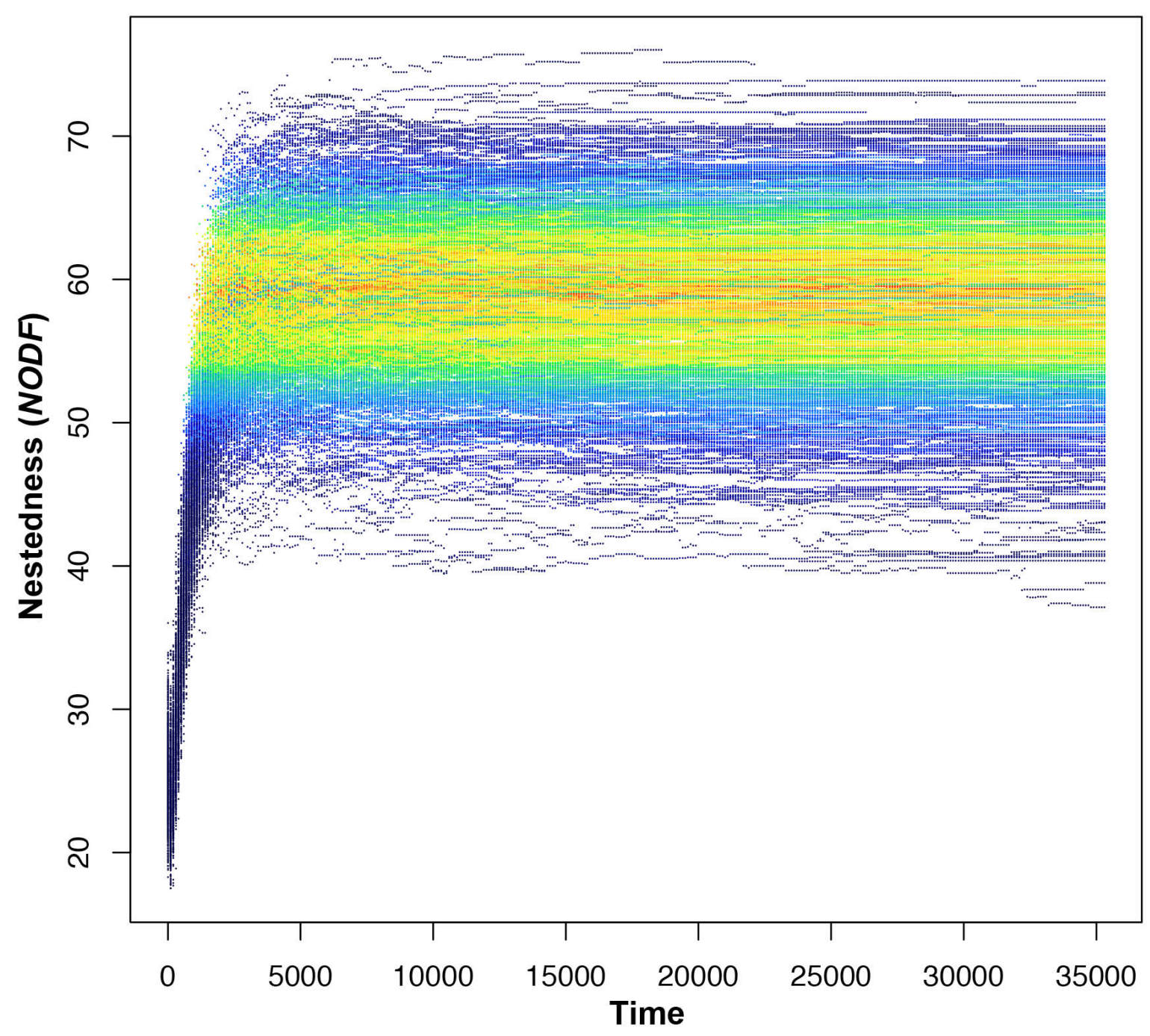




\section{Figure S3}
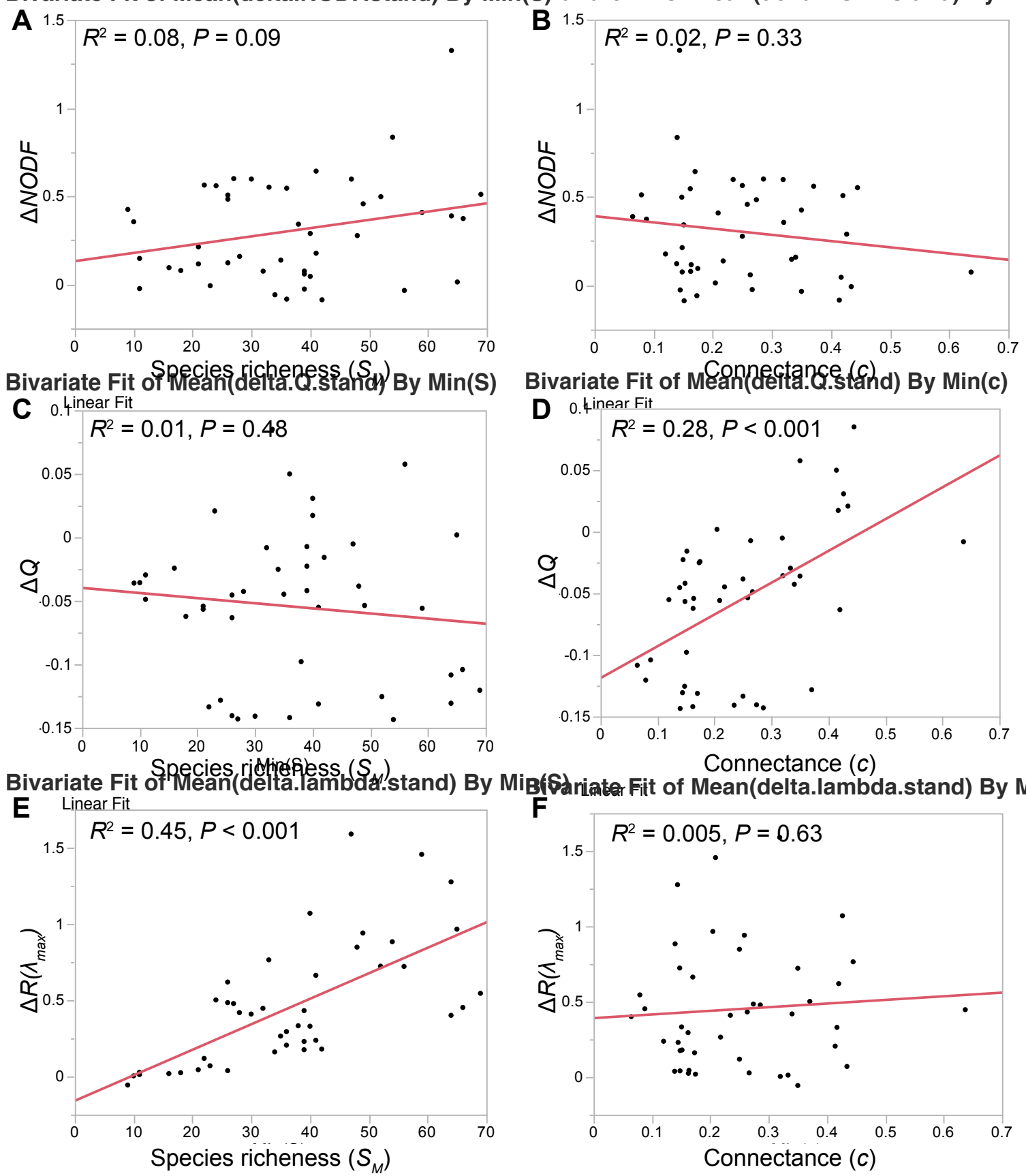


\section{Figure S4}
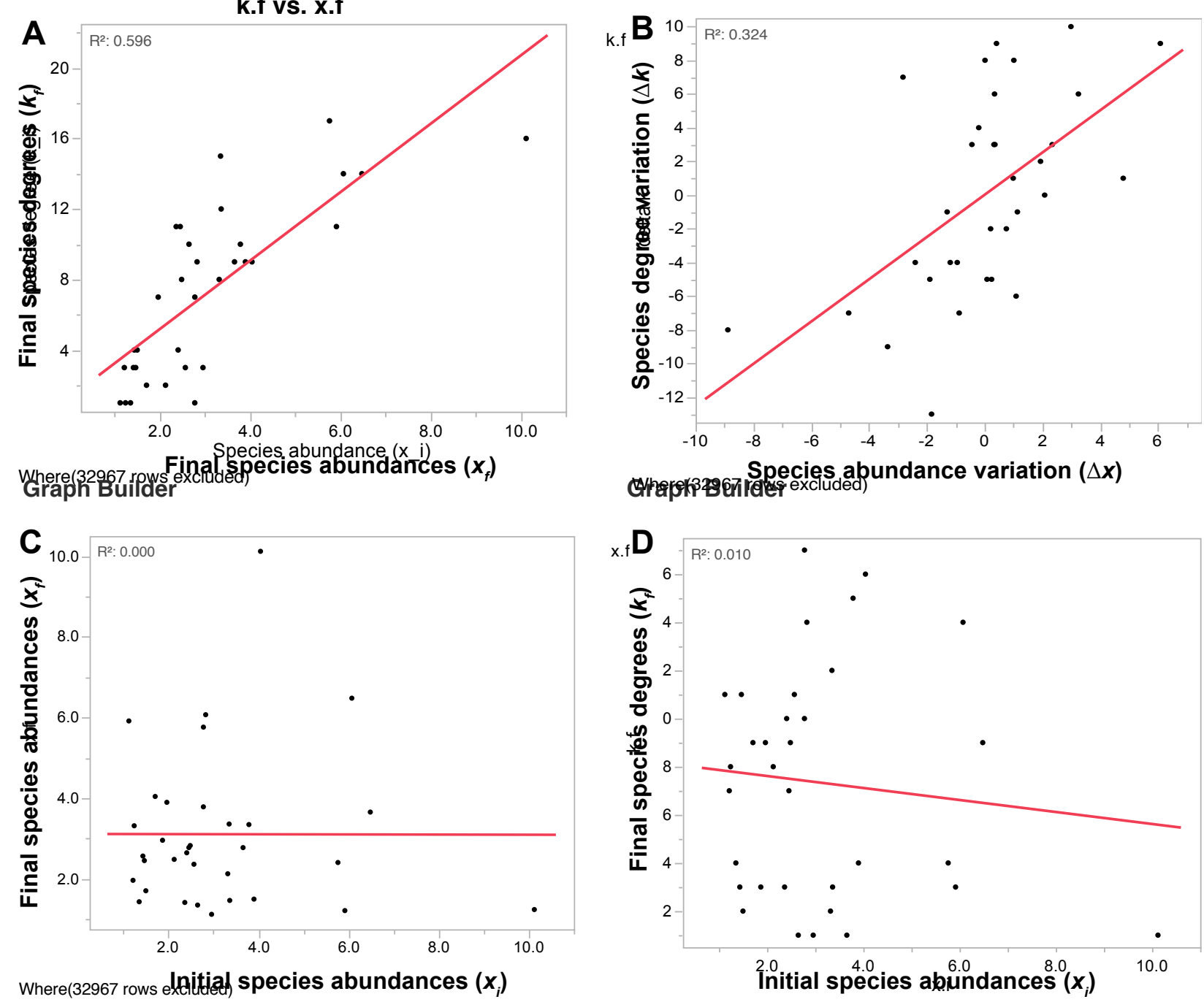
Figure S5
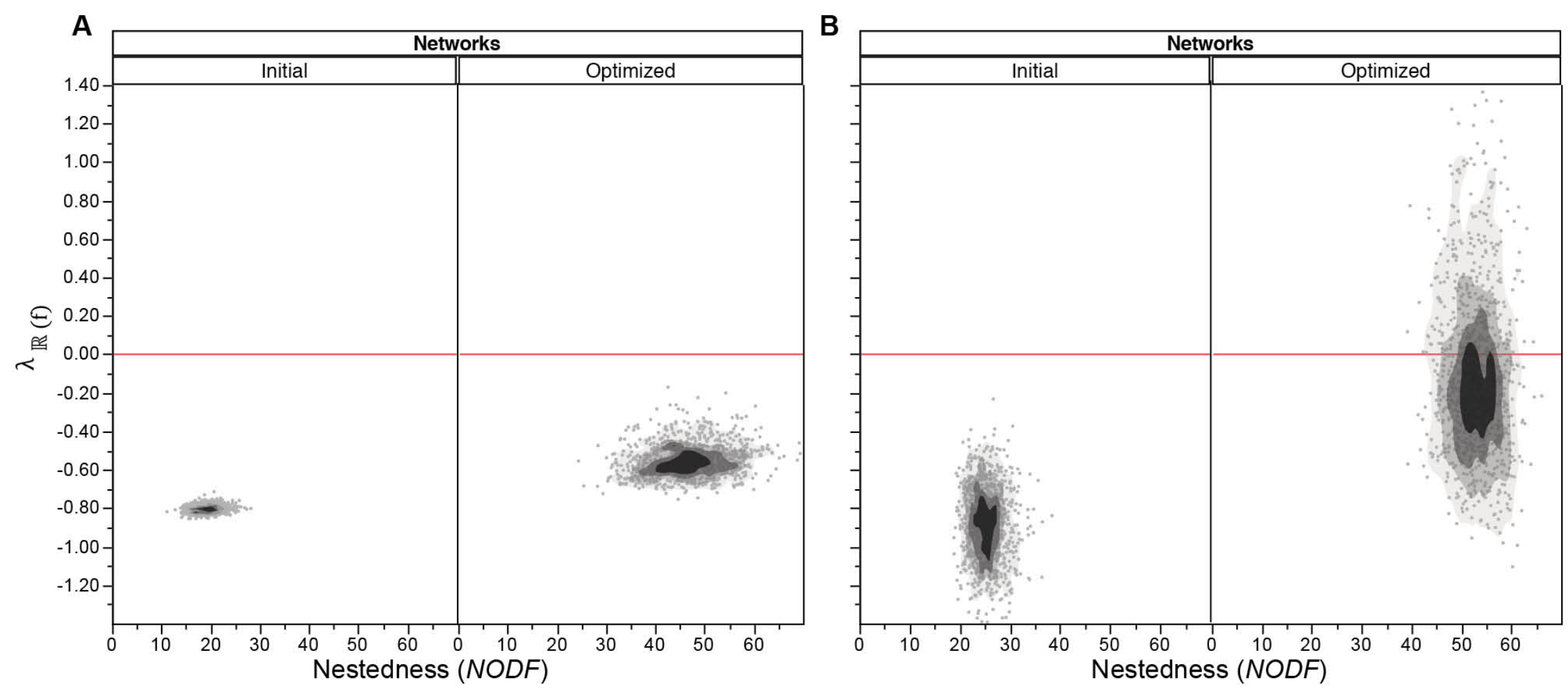
Figure S6

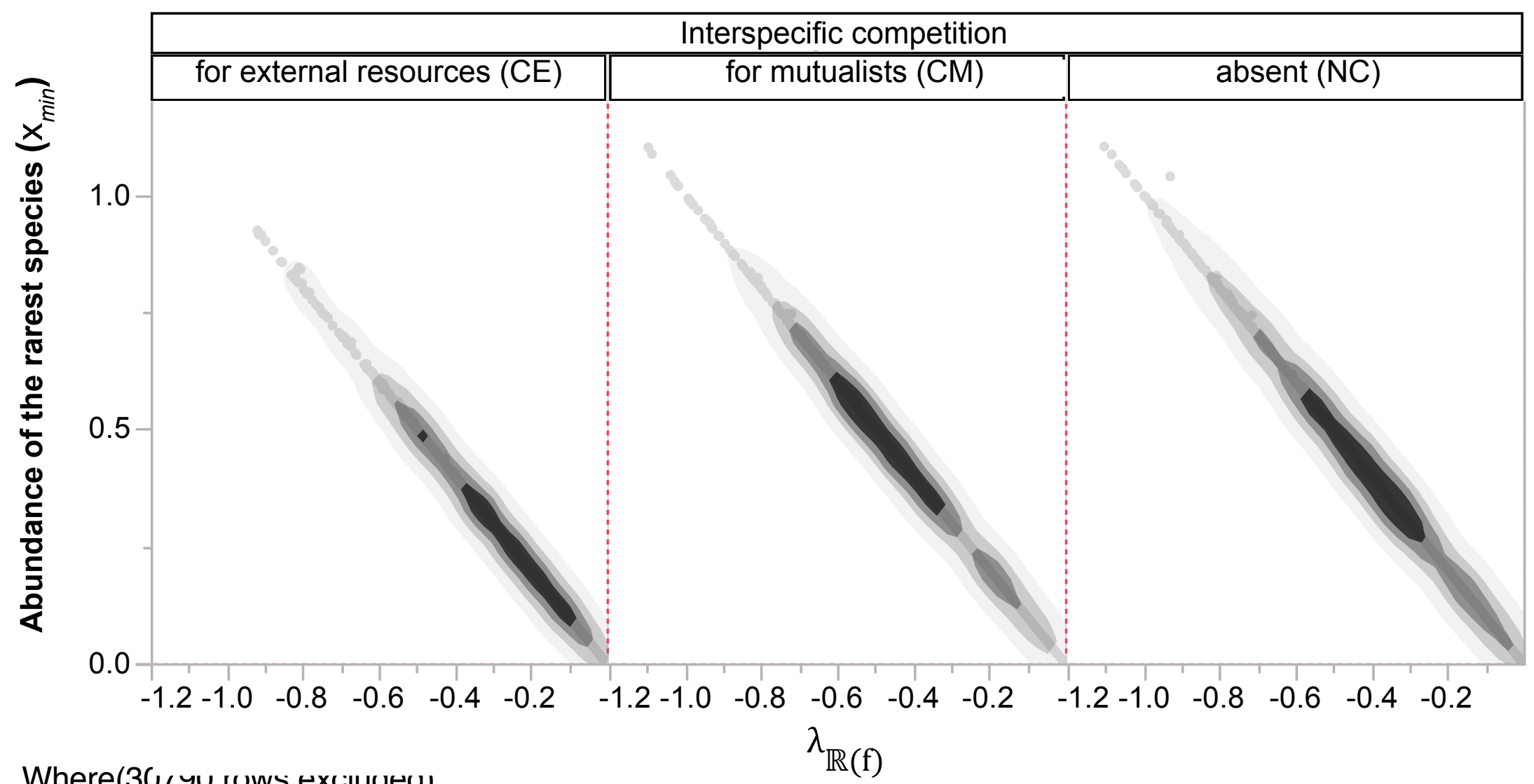




\section{Figure S7}

A

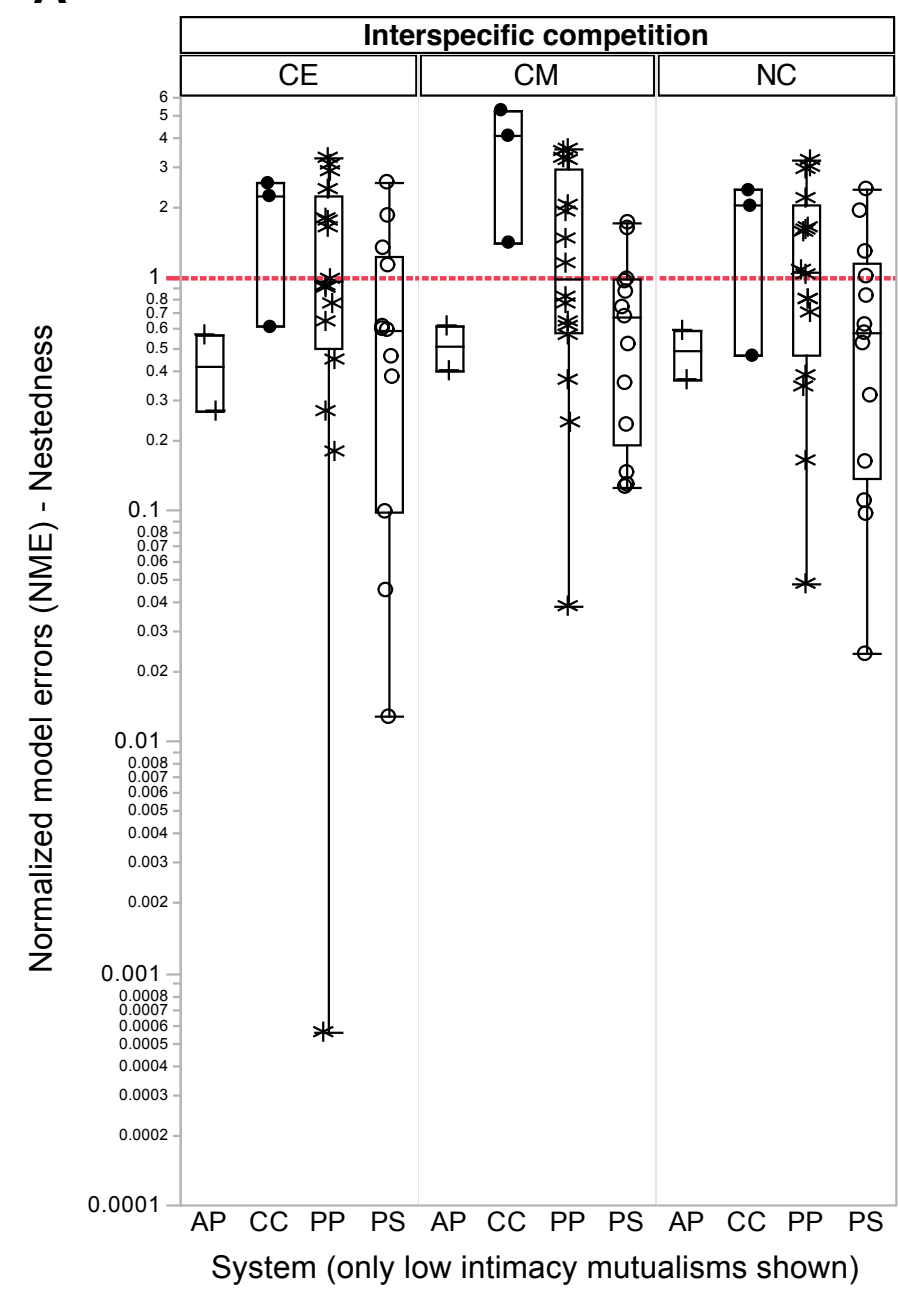

B

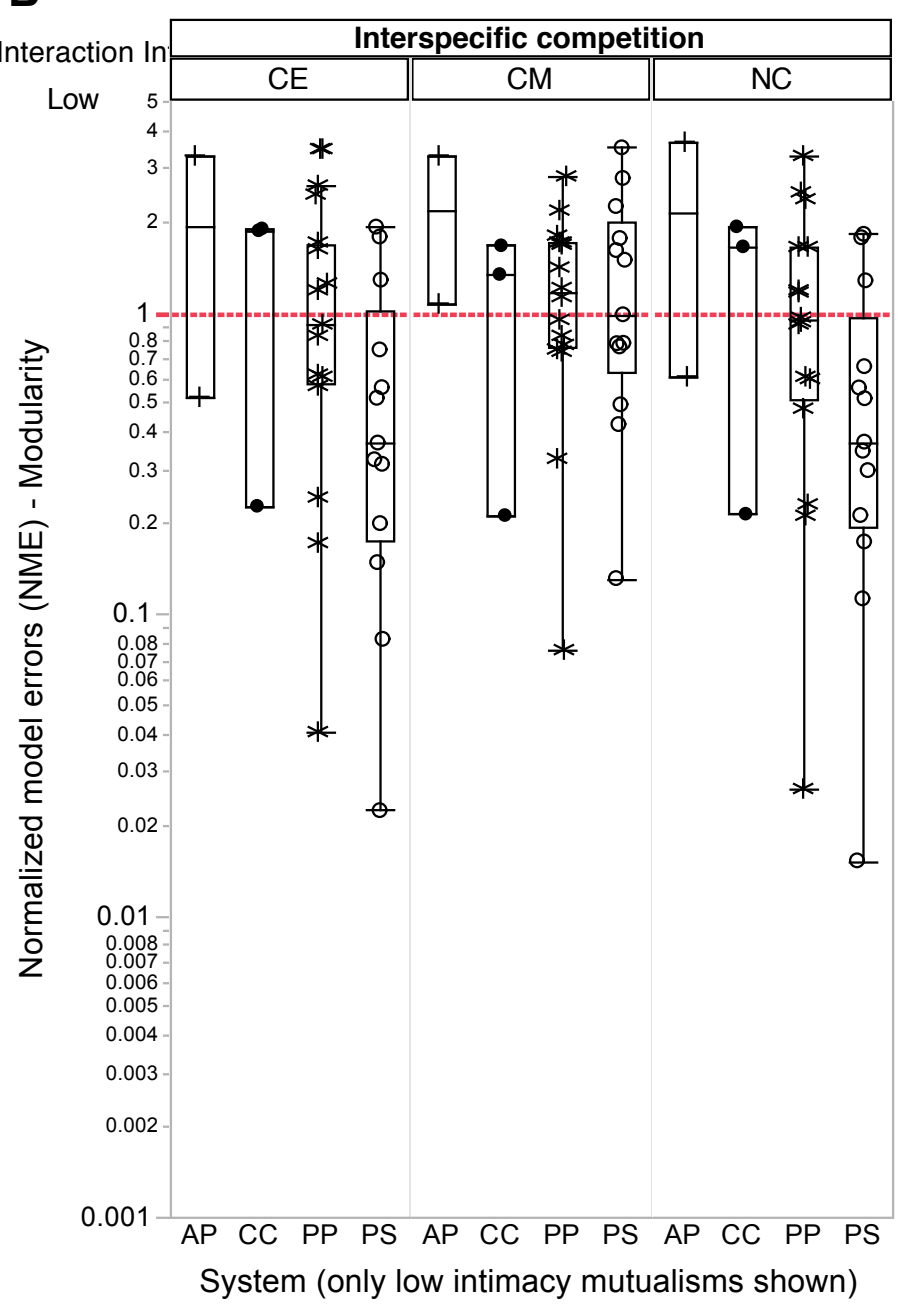


Figure S8

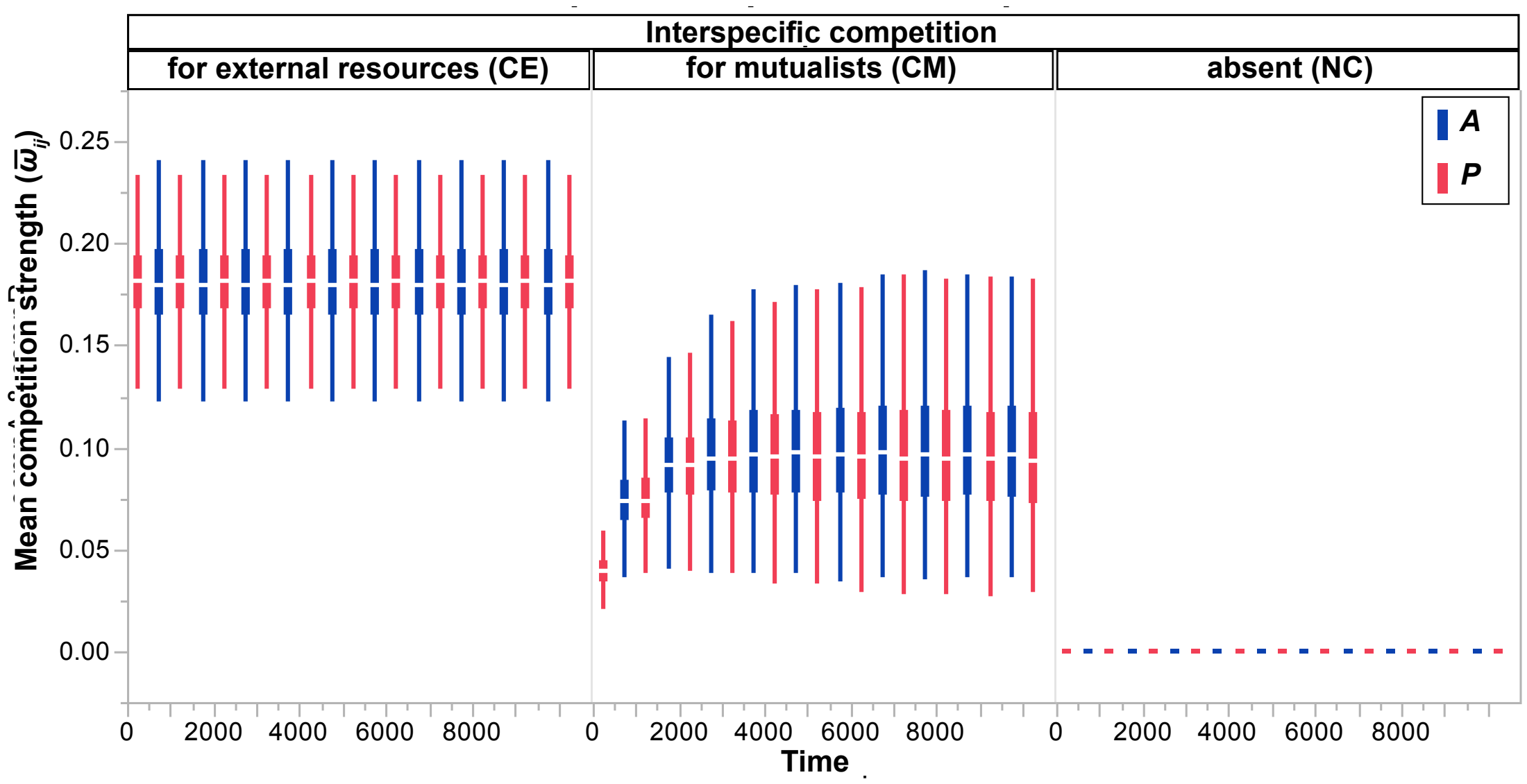


Figure S9

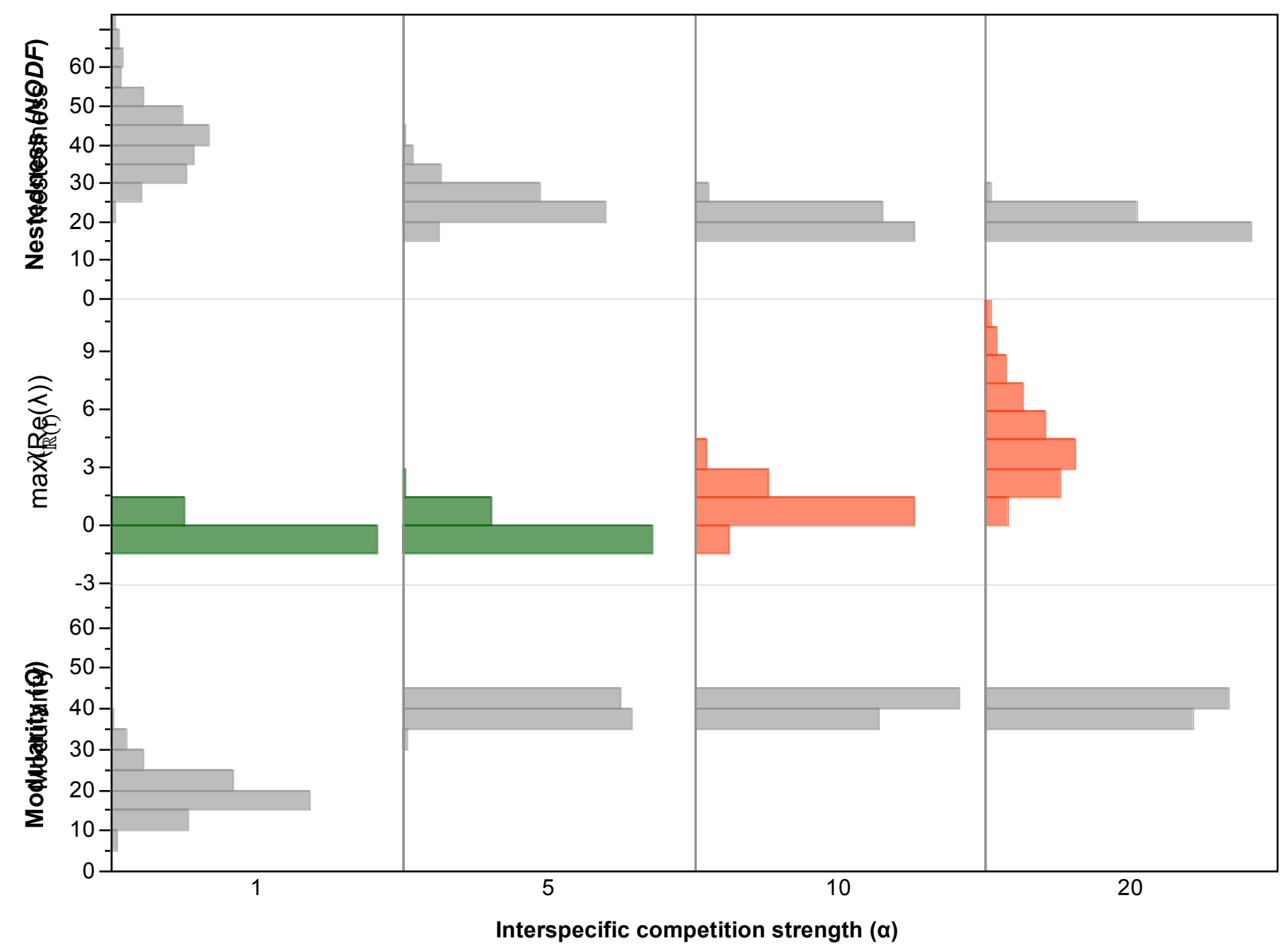




\section{Figure S10}

A
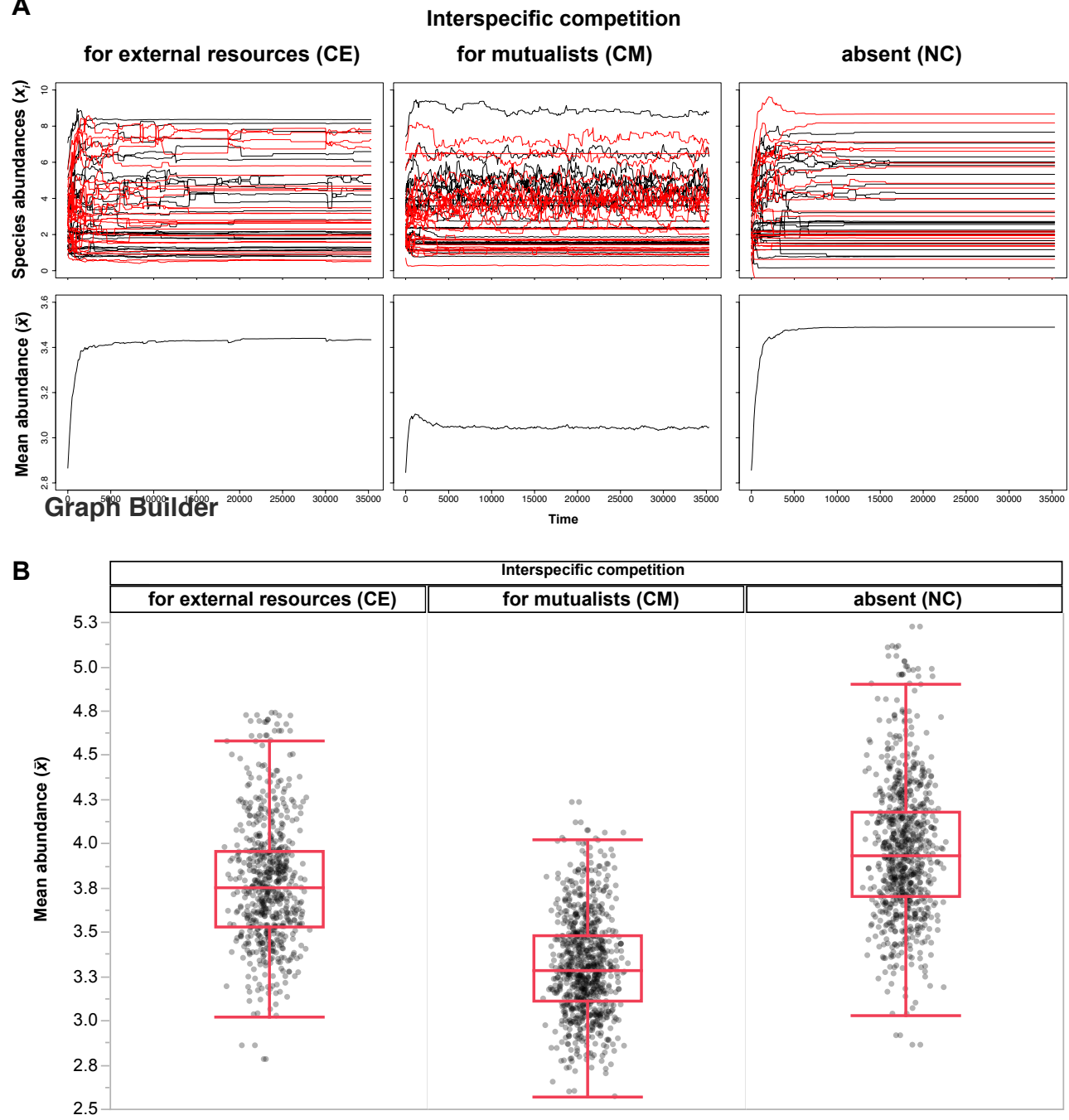
Figure S11
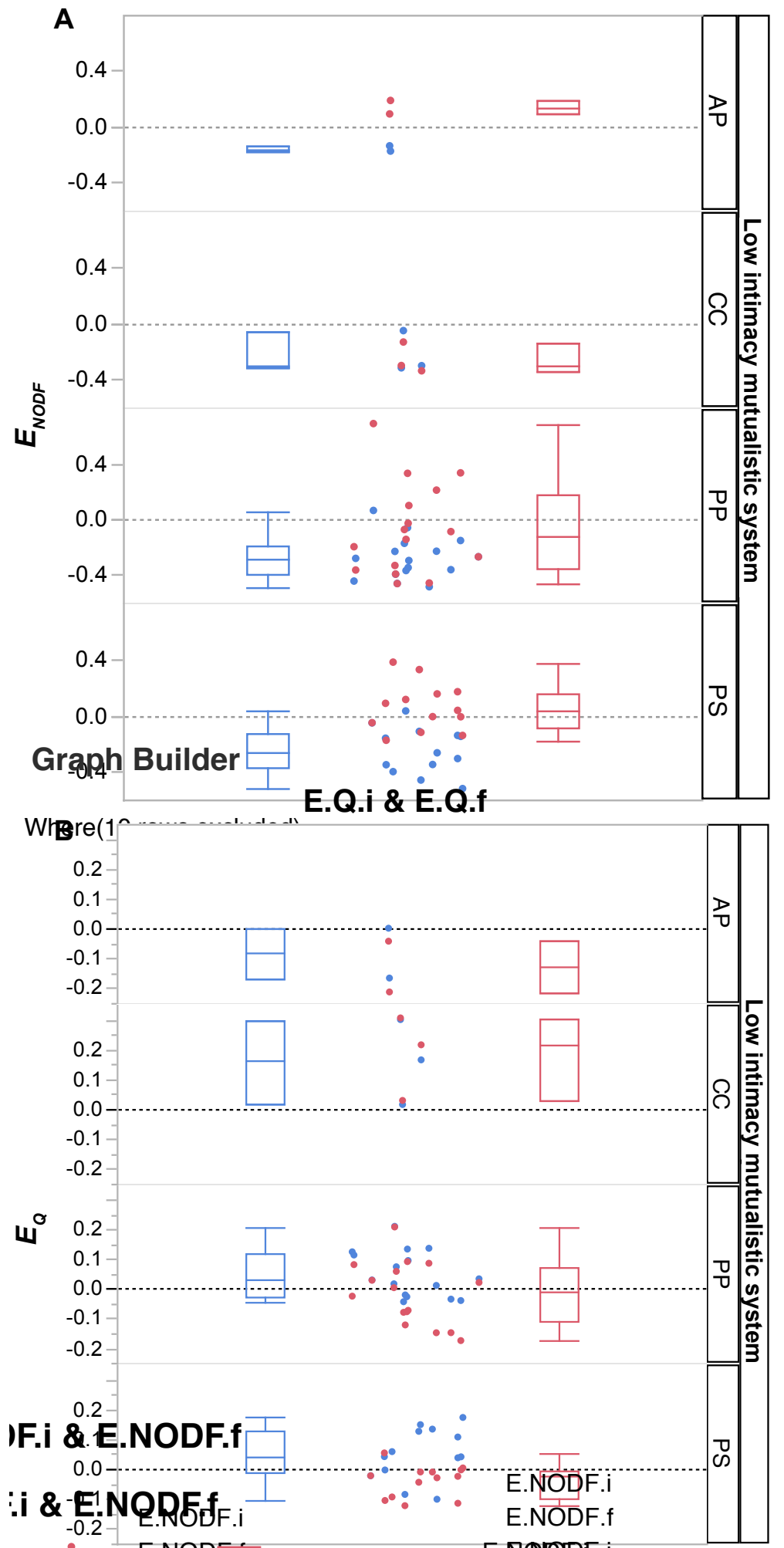

- 


\title{
CAPÍtulo 4
}

\section{Speciation, niche reorganization, and the stability of mutualistic networks}

\author{
Rafael L. G. Raimundo ${ }^{1}$, David. H. Hembry ${ }^{2}$, Flavia M. D. Marquitti ${ }^{1} \&$ \\ Paulo R. Guimarães $\mathrm{Jr}^{1}$ *
}

${ }^{1}$ Departamento de Ecologia, Instituto de Biociências, Universidade de São Paulo, Rua do Matão, Travessa 14, no. 321, 05508-900, São Paulo, SP, Brazil.

2 Department of Molecular and Cell Biology, University of California, Berkeley, CA 94720, USA.

*To whom correspondence should be addressed: prguima@usp.br.

Running title: Speciation and stability in mutualisms 


\begin{abstract}
The role of speciation in shaping ecological networks is mostly unknown. We performed computer simulations parameterized with data from 71 assemblages to investigate the effects of different speciation modes on mutualistic network architecture and stability. When a simulated speciation event causes niche width expansion (i.e., emerging species become more connected), connectance and nestedness increase and modularity decreases, which frequently lead to unstable networks, especially in species-poor assemblages. During speciation-induced niche width contraction (i.e., emerging species become less connected), connectance decreases and nestedness and modularity increase, promoting stability. Different rules of niche overlap between emerging species do not affect the emerging properties of model networks. These results are robust under different assumptions on interspecific competition regimes embedded in mutualistic networks. We suggest that effects of speciation on ecological dynamics may result from changes in connectance and modularity mediated by niche reorganization. Our models predict speciation-induced niche contractions caused by adaptive mechanisms (e.g., character displacement between recently diverged species) will not destabilize networks. However, niche-expanding speciation (e.g., due to allopatry via maintenance of shared ancestral interactions in association with the diverging addition of novel mutualists as a consequence of contrasting local adaptations) will destabilize local networks if emerging species undergo secondary contact. A single speciation event can strongly affect network structure, causing either persistence or collapse. Further studies of ecological interaction reorganization caused by diversification will deepen our understanding of biodiversity.
\end{abstract}

Keywords: Adaptive diversification, ecological speciation, niche evolution. 


\section{INTRODUCTION}

The work of May (e.g., 1973) set a landmark in the history of Ecology when it challenged the paradigm that species diversity fosters community stability (e.g., MacArthur 1955) by demonstrating that complexity in randomly built model communities leads to instability (see Allesina \& Tang 2012). A subsequent decades-long debate ensued over the conflict between this theoretical prediction and empirical records of a positive correlation between diversity and stability across different types of ecological communities (McCann 2000). However, a consensus was gradually reached that this apparent paradox indicated not that ecological networks must be unstable but rather that "real networks must have some contrasting, nonrandom structures that allow them to persist despite their complexity" (Bascompte 2010).

Structural patterns, such as modularity (Olesen et al. 2007) and nestedness (Bascompte et al. 2003), have been repeatedly described across different types of species networks. These nonrandom structures are related to stability in different ways. Modular structures are characterized by subsets of species that are more densely connected among themselves than with species in the rest of the network (Bascompte and Jordano 2014). Modularity is argued to decrease the stability of mutualisms, even though they enhance stability in antagonistic interactions (e.g., Thébault and Fontaine 2010). Another pervasive structure found in mutualistic networks is nestedness, a pattern in which highly connected species form a core by interacting mostly amongst themselves, whereas poorly-connected species interact with species in the core (Bascompte and Jordano 2014). Nestedness is often assumed to promote the stability of mutualistic networks by enhancing the positive effects of apparent facilitation and consequently minimizing the negative effects of interspecies competition (Bastolla et al. 2009; Thébault and Fontaine 2010; but see Allesina and Tang 2012).

The structure of ecological networks is expected to change over time as a consequence of different types of evolutionary dynamics such as interaction switches that maximize fitness and define the rewiring of the network structure (Suweis et al. 2013). Empirical evidence suggests that rewiring events are common among different types of mutualism (Bascompte \& Jordano 2014). It has been shown that the stability of ecological networks may be negatively affected by anagenetic evolutionary dynamics such as adaptive interaction switches (Suweis et al. 2013) or the directional selection of traits mediating intra- and interspecific interactions in species-rich communities (Loeuille 2010). 
Another key evolutionary process that affects the architecture and dynamics of biodiversity at multiple scales is speciation (Vellend 2010; Butlin et al. 2012; Hembry et al. 2014). Structural changes in ecological networks that affect stability are expected to arise because speciation simultaneously changes multiple attributes of the biotic environment (Schluter 2000b; Nosil 2012). For example, species additions to local mutualistic assemblages redefine the costs and benefits related to maintaining multiple interactions; therefore, a reorganization of biotic niche dimensions is expected over time (Jordano et al. 2003). As a result, a fundamental problem of evolutionary ecology is to understand whether and how the dynamical rearrangement of interactions imposed by species diversification affects the properties of ecological networks (Fortuna et al. 2010; Jordano \& Bascompte 2014).

The effects of speciation on network structure are expected to depend on the processes shaping phenotypic divergence and, consequently, niche divergence. The divergence of traits that mediate ecological interactions occurs under various geographic conditions ranging from sympatric (Doebeli and Dieckmann 2000) to allopatric (Losos and Mahler 2010) and can be driven by divergent natural selection, sexual selection, and/or genetic drift (Dieckmann et al. 2004). Trait divergence is often associated with the coexistence of species emerging from speciation processes (Schluter 2000a), and it relies on genetically based niche variation within and/or between populations (Svanbäck and Bolnick 2007; Araújo et al. 2011). Ecological and evolutionary processes related to species diversification can organize the ecological interactions of emerging species (Harmon et al. 2009; Trøjelsgaard et al. 2013), thereby affecting the width and overlap of the biotic dimensions of niches (Bolnick 2001; Anacker and Strauss 2014). Reorganization of the biotic dimensions of niche space after speciation implies the rewiring of the interaction network, leading to changes in structural properties such as connectance, nestedness, and modularity, which are key drivers of ecological dynamics (Abrams 1996; Bastolla et al. 2009; Allesina and Tang 2012).

We combined empirical data describing different types of mutualistic networks with simple numerical simulations to explore the dynamical consequences of structural changes in mutualistic interaction networks imposed by different modes of speciation. We assume that the structural effects of speciation vary according to evolutionary processes involved in or arising from species divergence, such as sympatric competitive speciation leading to ecological specialization (e.g., Dieckmann et al. 2004), divergent natural selection between environments (Schluter 2009), or vicariance events in which species sharing a common ancestor diverge allopatrically and then experience later range expansions leading to 
secondary contact (Hoskin et al. 2005). Interaction patterns of emerging species are therefore expected to correspond to niche reorganization arising from speciation (Schluter 2000a).

We modeled speciation-induced niche reorganization as a variation in niche width (i.e., in the number of mutualistic partner species in relation to the original species) and in niche overlap (i.e., how interaction patterns correlate between emerging species). Finally, we used qualitative stability analysis (May 1973, Allesina and Tang 2012) to assess the effects of variable types of structural changes caused by speciation on stability. In this approach, population densities are affected both by mutualistic and competitive interactions between species. We modeled two alternative biologically plausible scenarios of interspecific competition: one assuming that species compete for resources external to mutualistic interactions, and another assuming that species compete for mutualistic partners.

\section{METHODS}

\section{Simulating speciation modes and their effects on biotic niche organization}

We modeled the effects of different modes of speciation on the structures of mutualistic networks formed by two sets of species such as flowering plants $(P)$ and their animal pollinators $(A)$ (Figure 1A), comprising $S_{M}$ species. For any given simulation, we assumed that only one speciation event occurred.

Adding species to model mutualistic networks. To simulate the reorganization of mutualistic interactions following speciation, we first randomly sampled one parental species $E_{1}$, which could be either from $A$ or $P$ (Figure 1A), as the reference. We added one row (when $E_{1}$ belonged to the mutualist subset $A$ ) or one column (when $E_{1}$ belonged to $P$ ) to the matrix $\mathbf{B}_{a \times p}$ that depicts the mutualist network, with $a$ and $p$ being the number of species within $A$ and $P$, respectively. The new row or column of the interaction matrix $\mathbf{B}_{a \times p}, E_{2}$, corresponds to the new species emerging from speciation, which is identical to $E_{1}$ at this point. We then applied one of five interaction rewiring rules (Figure 1B-1F) defining the reorganization of the mutualistic interactions undergone by $E_{1}$ and $E_{2}$.

Interaction rewiring rules under speciation simulations. We used simple interaction rewiring rules to simulate the reorganization of biotic niche dimensions arising from speciation. Rewiring rules result from the combination of three governing parameters: $\xi_{1}, \xi_{2}$, and $\rho$ (Figure 1). Parameters $\xi_{1}$ and $\xi_{2}$, respectively, define changes in the number of mutualistic species $(k)$ with which $E_{1}$ and $E_{2}$ interact. Therefore, $\xi_{1}$ and $\xi_{2}$ are proxies for niche 
width variation. Under rewiring rules in which $\xi_{1}\left(\xi_{2}\right)=1$, species $E_{1}\left(E_{2}\right)$ interacts with its original partners plus $g$ new mutualistic species. When $\xi_{1}\left(\xi_{2}\right)=-1$, species $E_{1}\left(E_{2}\right)$ reduces the number of interacting partners by $g$ species. If $\xi_{1}\left(\xi_{2}\right)=0$, the species degree $(k)$ does not change. For each simulation, $g$ is obtained by rounding to the nearest whole number a value sampled from a Gaussian distribution with mean $\mu_{g}=0$ and standard deviation $\sigma_{g}=0.5$. The absolute value of $|g|$ is thus added to or subtracted from the $k$ links of species $E_{1}$ or $E_{2}$, as determined by $\xi_{1}$ and $\xi_{2}$. The parameter $\rho$ describes the correlation rule applied when adding or subtracting the interactions defined by $\xi_{1}$ and $\xi_{2}$, thus defining the degree of niche overlap between emerging species. If $\rho=-1$, then interaction switches in $E_{1}$ and $E_{2}$ are negatively correlated, and the species are likely to undergo dissimilar structural changes. If $\rho=0$, the structural changes in $E_{1}$ and $E_{2}$ are uncorrelated.

Speciation models. Combinations of $\xi_{1}, \xi_{2}$, and $\rho$ simulate a variety of structural effects that can be imposed on mutualistic networks by speciation. Under model CON1 (Figure 1B), the niche width contracts and the number of mutualistic interactions by both species decreases after the speciation event $\left(\xi_{1}\right.$ and $\left.\xi_{2}=-1\right)$. Additionally, link deletions are negatively correlated, and therefore niche overlap decreases, (i.e., differences arise between the sets of mutualistic partners of $E_{1}$ and $E_{2}[\rho=-1]$. This negatively correlated decrease in the number of mutualistic partners can result from a number of adaptive processes, such as competitive sympatric speciation leading to character displacement (Bhattacharyay and Drossel 2005), ecological speciation driven by divergent selection between habitats (Nosil 2012), and reciprocal co-evolutionary specialization (Thompson 2005). In the allopatric cases just described, the model simulates secondary contact. Model CON2 represents a control for the effects of the negative correlation in niche contraction in CON1 because it is a niche contraction model $\left(\xi_{1}\right.$ and $\left.\xi_{2}=-1\right)$ with no correlation between link deletions $(\rho=0$; Figure 1C). Such uncorrelated link deletions (CON2) could be generated, for example, by mutationorder speciation (Schluter and Conte 2009) in which diverging populations would fix alternative mutations as they adapt to the same selective pressures (towards specialization) in different locations.

The model EXP1 depicts niche width expansion $\left(\xi_{1}\right.$ and $\left.\xi_{2}=1\right)$ in which link additions are negatively correlated $(\rho=-1$; Figure 1E). Such an outcome of speciation is plausible when ecologically similar species originating from allopatric speciation experience secondary contact. The exploitation of contrasting complementary mutualistic partners would mitigate interspecific competition between emerging species undergoing secondary contact by 
providing competitive refugia (Robinson and Wilson 1998). Model EXP2 represents a control for EXP1 because EXP2 is also a model of niche width expansion in which link additions are not correlated $(\rho=0$; Figure $1 \mathrm{~F})$ and emerging species will have, on average, a higher degree of niche overlap compared with EXP1. Morphological and/or behavioral divergences under vicariance, which can also be associated with geographically variable selection (Thompson 2005), are plausible explanations for uncorrelated increases in niche width (EXP2). In this sense, populations diverging in allopatry can adapt to additional locally abundant resources before undergoing geographic range expansion and experiencing secondary contact. Finally, model GM represents a general control in which speciation does not affect niche properties $\left(\xi_{1}\right.$ and $\left.\xi_{2}=0\right)$. Therefore, $E_{2}$ has the same number of interactions as $E_{1}$, but its interacting partners are randomly distributed among all existing mutualistic species ( $\rho=0$; Figure 1D).

Other focal species $E_{1}$ and $g$ were sampled if a species holding only one interaction was sampled to undergo niche contraction or when summing $g$ links with the original number of interactions $(k)$ exceeded the number of existing mutualistic partner species. We defined that the species $E_{l}$ undergoing speciation belonged to one set of mutualistic partners $(P)$ in $50 \%$ of the simulation replicates, and in the other $50 \%$ of replicates, $E$ belonged to the other mutualistic set $(A)$.

\section{Dataset and types of mutualistic networks}

We parameterized the size $\left(S_{M}\right)$, connectance $(C)$, and the number of species in each set of mutualistic species ( $P$ and $A$ ) of a mutualistic network using data on species interactions from 71 mutualistic assemblages widespread throughout diverse terrestrial and marine ecosystems widely distributed among diverse ecogeographic regions (Supplementary Table S1). Our dataset includes 53 low-intimacy (L) and 18 high-intimacy (H) mutualistic networks. Interaction intimacy refers to the degree of morphological, physiological, and behavioral integration between species (Ollerton 2006). In low-intimacy interactions, each interaction event has a relatively low impact on fitness, and individuals interact with many individual mutualistic partners. On the other hand, in high-intimacy interactions, each interaction event has a high impact on fitness, and individuals interact with one or few individual partners (Ollerton 2006; Guimarães et al. 2007; Raimundo et al. 2014).

The low-intimacy networks in our dataset encompass a variety of ecological interactions and include 28 assemblages of flowering plants and animal pollinators (PP), 17 assemblages of zoochoric plants and seed-dispersing animals (PS), 5 assemblages of 
mutualisms between plants with extrafloral nectaries and protective ant species (AP), and 3 assemblages of cleaner species of fishes and shrimps and their client fishes (CC). The highintimacy networks include 11 assemblages of anemone fishes and their host sea anemones as well as 7 assemblages of mutualisms between myrmecophyte plants and associated ant species (MAP).

\section{Assessing the effects of speciation on network structure}

We used three descriptors to characterize network structure: connectance, $C=I /($ ap $)$, in which $I$ is the number of observed interactions between mutualistic species pairs and $a p$ is the number of potential interactions; nestedness, estimated using the NODF metric (AlmeidaNeto et al. 2008); and modularity, here computed using a modification of the $Q$ metric designed for bipartite networks (Barber 2007) based on the simulated annealing algorithm implemented in the software MODULAR (Marquitti et al. 2013). MODULAR was also used to compute the number of modules in each simulated network.

To characterize speciation-induced structural changes in mutualistic networks across the five speciation models, we ran 100 simulated replicates per model for each of the 71 networks in our dataset, thus totaling 36,000 replicates. For each replicate, we simulate only one speciation event, and the variation in the network descriptors before and after simulated speciation was computed by subtracting the initial value of the descriptor before speciation, $D_{i}$, from its value, $D_{f}$, after speciation and dividing the result by $D_{i}$, thereby allowing the comparison of structural changes across different mutualistic networks. The structural change indexes describing the effects of speciation-induced niche reorganization on mutualistic networks are thus $\Delta C=\left(C_{i}-C_{f}\right) / \mathrm{C}_{i}$ (connectance), $\triangle N O D F=\left(N O D F_{i}-N O D F_{f}\right) / N O D F_{i}$ (nestedness), $\Delta Q=\left(Q_{i}-Q_{f}\right) / \mathrm{Q}_{i}$ (modularity), and $\Delta m=\left(m_{i}-m_{f}\right) / m_{i}$ (number of modules).

To test for differences between the mean values of structural change descriptors $(\Delta C$, $\triangle N O D F$, and $\triangle Q$ ) across speciation models, we performed one-way analysis of variance (ANOVA). We used the five different speciation models as levels of the same factor. As the response variable, we used the mean value of each descriptor obtained from 100 simulation replicates for each network and model. Whenever necessary, variables were log transformed to improve normality and homoscedasticity. If ANOVA identified differences among descriptor means across speciation models, we applied post-hoc Tukey's Honestly Significant Difference (HSD) tests to describe the pattern of differences between means (Stoline 1981). 


\section{Assessing the effects of speciation on community stability}

Each of the 71 mutualistic networks in our dataset corresponds to a binary interaction matrix, $\mathbf{B}_{a \times p}$, with empirically informed dimensions, connectance and interaction structure. Departing from $\mathbf{B}_{a \times p}$, we subsequently built a community matrix $\mathbf{T}$ with dimensions $S_{M} \mathrm{X} S_{M}$, where $S_{M}=a+p$. Matrix $\mathbf{T}$ describes the ecological interactions within the community, summarizing the per-capita effects on species abundance imposed by mutualistic partner species, competitor species, and intraspecific competition. Each cell $t_{i j}$ depicts the effect of a species $i$ on a species $j$ (interaction strength) around a feasible equilibrium, and therefore $\mathbf{T}$ is an approximation of the Jacobian matrix, J (Allesina and Tang 2012). Local stability - the tendency of the system to return to equilibrium after small perturbations - is described by the real part of the leading eigenvalue $\left(\lambda_{\mathrm{R}}\right)$ of $\mathbf{J}$. The equilibrium point is stable if the real part of the leading eigenvalue of $\mathbf{J}$ is negative $\left(\lambda_{R}<0\right)$, but it is unstable when $\lambda_{R}>0$ (May 1973; Allesina and Tang 2012).

If a cell $t_{i j}$ corresponds to a mutualistic interaction $\left(i \in A, j \in P\right.$ and $\left.\mathbf{B}_{(i j)}=1\right)$, then the interaction strength describing the effect of $j$ on the abundance of $i$ is defined as $t_{i j} \sim$ $\left|\mathcal{N}\left(\mu, \sigma_{\Gamma}\right)\right|$, where $\mathcal{N}\left(\mu, \sigma_{\Gamma}\right)$ is the normal distribution with mean $\mu=0$ and standard deviation $\left(\sigma_{\Gamma}\right)=0.054$, and $|x|$ is the sampled absolute value. Mutualistic interactions are assumed to be asymmetric with regard to interaction strength $t_{i j} \neq t_{j i}$, a widespread attribute of plant-animal ecological networks (Bascompte and Jordano 2014). Interaction strength of mutualistic interactions did not change after speciation. In simulations of speciation-induced niche expansion, the strength of a new mutualistic interaction added to an emerging species was defined in the form described above, i.e., $t_{i j} \sim\left|\mathcal{N}\left(\mu, \sigma_{\Gamma}\right)\right|$.

We modeled two alternative scenarios for filling a cell $t_{i j}$ that correspond to the interspecific competition interactions, $i \in A(P)$ and $j \in A(P)$. The first scenario (named $\mathrm{M}$ ) assumes that interspecific competition does not occur and that $t_{i j}=0$. In the alternative scenario (MC), competition between a pair of species $i$ and $j$ is defined by the overlap in mutualistic partner use, defined as $t_{i j}=\sum_{k}^{A(P)} t_{i k} t_{k i}$. Diagonal elements of $\mathbf{T}$ depict intraspecific competition, which is fixed as $t_{i i}=-1$. In the scenario in which species compete for mutualistic partners (MC), the values $t_{i j}$ describing interspecific competition are redefined after speciation, as the overlap in resource use among species in the assemblage is affected by the speciation event. 
We measured the effects of niche reorganization associated with speciation on community stability by following the same rationale used for describing structural changes. The effect of a speciation event on stability was defined as $\Delta \lambda_{R}=\left(\lambda_{R(f)}-\lambda_{R(i)}\right) /\left|\lambda_{R(i)}\right|$, where $\lambda_{\mathrm{R}(\mathrm{i})}$ is the real part of the leading eigenvalue of $\mathbf{J}$ before speciation, $\left|\lambda_{\mathrm{R}(\mathrm{i})}\right|$ is its absolute value, and $\lambda_{\mathrm{R}(\mathrm{f})}$ is their counterpart after speciation. To control for the effect of network size on speciation-induced stability variation, we standardized our descriptor of changes in stability as $\Delta \lambda_{\mathrm{R}} / S_{M}$, which represents the percentage of stability variation per species in the network. Negative values of $\Delta \lambda_{\mathrm{R}} / S_{M}$ imply that speciation has a stabilizing effect on population dynamics within the network, whereas positive values indicate a destabilizing effect.

To characterize changes in stability across the five different speciation models summarized in Figure 1, we ran 50 simulation replicates per model and interspecific competition scenario (2) for each of the 71 networks in our dataset, thus totaling 36,000 simulation replicates. Mean values of $\Delta \lambda_{\mathrm{R}}$ and/or $\Delta \lambda_{\mathrm{R}} / S_{M}$ for each network and speciation model were used as proxies to characterize speciation-induced stability variation Statistical procedures similar to the procedures used in the structural change analyses were used to test for differences between the mean change in stability among speciation models. Additionally, we complemented the characterization of speciation effects on mutualistic network structure by computing the percentage of simulations in which $\Delta \lambda_{R}<0$ (i.e., speciation imposes a stabilizing effect on population dynamics) for each network under each speciation model.

\section{RESULTS}

\section{Effect of speciation mode on network structure}

Niche reorganization resulting from simulated speciation modes has different effects on the structure of model mutualistic networks (Figure 2). The basic effect was variation in the number of interactions $(\Delta k)$, which corresponds to changes in niche width that arise from interaction rewiring rules imposed under each speciation model (Figure 1). In the EXP1 and EXP2 models of niche expansion, the average increase in the absolute number of interactions per species was $\Delta \bar{k}=1.9 \pm 0.4$ links, whereas in both the CON1 and CON2 models of niche contraction, the average decrease in the number of interactions per species was $\Delta \bar{k}=-1.7 \pm$ 0.5 links (Figure 2A). 
The effects of niche reorganization on connectance $(\Delta C)$ differed among our five speciation models $\left(F_{4,350}=57.5, P<0.001\right)$. The average change in connectance was positive under the niche expansion models $(\Delta \bar{C}=11.5 \pm 11.7 \%$ for EXP1 and $\Delta \bar{C}=11.5 \pm 11.8 \%$ EXP2), close to zero under the general control model (GM, $\Delta \bar{C}=1 \pm 3 \%$ ) and negative under the niche contraction speciation models $(\Delta \bar{C}=-3.8 \pm 4.8 \%$ for CON1 and $\Delta \bar{C}=-4.7 \pm 8.2 \%$ for CON2). However, there were no differences in $\Delta \bar{C}$ between EXP1 and EXP2 or between CON1 and CON2 (Tukey's HSD test, $\mathrm{Q}=2.74, P<0.01$ for all pairwise combinations except for those between CON1/CON2 and EXP1/EXP2, the latter being $P=0.96$ and $P=1$, respectively; Figure $2 \mathrm{~B})$. Species richness $\left(S_{M}\right)$ was negatively related to the connectance changes described by $\Delta C$, regardless of the speciation model considered $\left(R^{2}=0.62\right.$ for both EXP1 and EXP2; $R^{2}=0.70$ and 0.72 for CON1 and CON2, respectively; $P<0.001$ for each of the four models), with the exception of the general control model (GM, $R^{2}=0.025, P=$ 0.17). Initial connectance $(C)$ was negatively related to $\Delta C$ and accounted for its variation only in the niche contraction models $\left(R^{2}=0.35\right.$ and 0.36 for CON1 and CON2, respectively; $P<0.001)$.

Mean nestedness increased after simulated speciation $(\triangle \overline{N O D F}>0)$ under all speciation models (Figure 2C), but the degree of nestedness acquired differed significantly among them $\left(F_{4,350}=6.2, P<0.001\right)$. Speciation models in which emerging species expand their niches acquired the greatest nestedness $(\triangle \overline{N O D F}=137 \pm 207 \%$ for EXP1 and $\triangle \overline{N O D F}$ $=140.7 \pm 207 \%$ for EXP2), which differed significantly from the niche contraction models $(\triangle \overline{N O D F}=77 \pm 165 \%$ for CON1 and $\triangle \overline{N O D F}=80.4 \pm 170 \%$ for CON2). However, $\Delta \overline{N O D F}$ did not differ between the general control model GM, which was characterized by an intermediate degree of nestedness acquirement $(\triangle \overline{N O D F}=98 \pm 174.5 \%)$ and both the niche expansion and contraction models. Additionally, no difference was observed between the EXT1/EXT2 and CON1/CON2 models (i.e., differences in the pattern of niche overlap between emerging species did not imply qualitatively different structural outcomes; Tukey's HSD test, $\mathrm{Q}=2.74 ; P<0.01$ for significantly different pairwise combinations of speciation models, and $P>0.3$ for the non-significant combinations; Figure $2 \mathrm{C})$. Species richness $\left(S_{M}\right)$ did not explain the nestedness changes described by $\triangle N O D F$ in the niche expansion models and in the general control $\left(R^{2}<0.07\right.$ and $P>0.4$ for EXP1, EXP2, and GM), but it was positively related to nestedness acquisition in the niche contraction models $\left(R^{2}=0.26\right.$ for CON1 and $R^{2}=0.29$ for CON2, $\left.P<0.001\right)$. Initial connectance $(C)$ was weakly and negatively related to $\triangle N O D F$ across speciation models $\left(0.16>R^{2}>0.07\right.$ and $\left.P<0.05\right)$. 
Mean change in modularity $(\Delta \bar{Q})$ significantly differed across speciation models $\left(F_{4,350}=42.8, P<0.001\right)$. Networks had a negative mean modularity change under the niche expansion models, with no differences occurring between EXP1 and EXP2 $(\Delta \bar{Q}=-10 \pm 10 \%$ for EXP1 and $\Delta \bar{Q}=-10 \pm 11 \%$ for EXP2). This decrease in $\Delta \bar{Q}$ was five times greater than in the general control model GM $(\Delta \bar{Q}=-2 \pm 2 \%)$. In contrast, modularity had a mean positive change under the niche contraction models $(\Delta \bar{Q}=5 \pm 11 \%$ for CON1 and $\Delta \bar{Q}=6 \pm 12 \%$ for CON2), which differed significantly from the remaining expansion and control models but not between themselves (Tukey's HSD test, $\mathrm{Q}=2.74 ; P<0.01$ for significantly different pairwise combinations of speciation, and $P>0.95$ for the non-significant combination; Figure 2D). Change in the number of modules, $\Delta m$, was very low across speciation models $(\Delta \bar{m}<$ $5 \%$ for all models). Negative $\Delta \bar{m}$ in the niche expansion models differed from positive $\Delta \bar{m}$ in the niche contraction models, but the means of both groups did not differ significantly from the general control model (Tukey's HSD test, $\mathrm{Q}=2.74, P<0.01$ ). Additionally, $\Delta \bar{m}$ explained no more than a small fraction of $\Delta Q$ across speciation models $\left(R^{2}<0.14, P<0.001\right.$ for EXP1, EXP2, CON1, and CON2; $\left.R^{2}=0.02, P=0.16\right)$. Species richness $\left(S_{M}\right)$ was positively related to $\Delta Q$ under niche expansion models $\left(R^{2}=0.78, P<0.001\right.$ for both EXP1 and EXP2), uncorrelated under the general control model $\left(\mathrm{GM}, R^{2}=0.05, \mathrm{P}=0.05\right)$, and negatively related to $\Delta Q$ under the niche contraction model $\left(R^{2}=0.58\right.$ for EXP1 and $R^{2}=$ 0.60 for EXP2, $P<0.001)$. Initial connectance $(C)$ was negatively related to the changes in modularity $(\triangle Q)$ under niche expansion $\left(R^{2}=0.17, P<0.001\right.$ for EXP1 and $R^{2}=0.18, P<$ 0.001 for EXP2) and positively related to $\Delta Q$ under the niche contraction models $\left(R^{2}=0.32\right.$, $P<0.001$ for CON1 and $R^{2}=0.34, P<0.001$ for CON2) but did not explain the $\Delta Q$ variation under the general control model $\left(\mathrm{GM}, R^{2}=0.003, P=0.13\right)$.

\section{Effects of speciation mode on stability}

A two-factor ANOVA revealed significant effects of speciation models $\left(F_{9,710}=103.7, P<\right.$ $0.001)$ and interspecific competition scenarios $\left(F_{9,710}=5.83, P=0.015\right)$ on stability variation $\left(\Delta \lambda_{\mathrm{R}} / S_{M}\right)$. There was no significant interaction between these factors $\left(F_{9,710}=0.83, P=0.5\right)$. The effects of each speciation model on stability were qualitatively equivalent between interspecific competition scenarios (Figure 3A). A Tukey's post-hoc test showed that speciation events under niche expansion were, on average, destabilizing $\left[\overline{\Delta \lambda_{\mathrm{R}} / S_{M}}=2(1.8) \pm\right.$ $1.8(1.7) \% /$ species for EXP1 under scenarios $\mathrm{M}(\mathrm{MC})$ and $\overline{\Delta \lambda_{\mathrm{R}} / S_{M}}=2.2$ (1.8) \pm 2 
(1.7)\%/species for EXP2]. In the general control model (GM), changes in stability were very low, but, on average, effects were destabilizing $\left[\overline{\Delta \lambda_{\mathrm{R}} / S_{M}}=0.6(0.3) \pm 0.6(0.4) \% /\right.$ species $]$. Finally, a mean destabilizing effect occurred in the niche contraction speciation models (CON1 and CON2) when interspecific competition was absent (scenario M), but the effect was stabilizing if the species competed for mutualists [scenario $\mathrm{MC} ; \overline{\Delta \lambda_{\mathrm{R}} / S_{M}}=0.02(-0.01)$ $\pm 0.06(0.03) \% /$ species for CON1 and $\overline{\Delta \lambda_{\mathrm{R}} / S_{M}}=0.01(-0.015) \pm 0.06(0.04) \% /$ species for CON2]. Importantly, the percentage of simulations in which $\Delta \lambda_{R}<0$ (i.e., speciation imposes a stabilizing effect on population dynamics) is much higher in models of speciation-induced niche contraction $(\bar{X}=26 \pm 10.9 \%$ for CON1 and $\bar{X}=25.3 \pm 9.2 \%$ for CON2) than in the models of speciation-induced niche expansion, being close to zero in the latter $(\overline{\mathrm{X}}=0.3 \pm 0.8 \%$ for EXP1 and $\bar{X}=0.3 \pm 0.7 \%$ for EXP2; $n=100$ simulations for each network and model; Figure 4).

We subsequently investigated the relationship between network stability $\left(\Delta \lambda_{\mathrm{R}} / S_{M}\right)$ and species diversity under different models of speciation. Speciation models implying niche width expansion (EXP1 and EXP2) destabilized mutualistic networks $\left(\Delta \lambda_{\mathrm{R}} / S_{M}>0\right)$. No qualitative difference was observed between niche expansion models when assuming negatively correlated (EXP1) and uncorrelated (EXP2) link additions. In both models, low-tointermediate diversity communities (7-70 species) experienced higher per-species destabilizing effects, which decayed and approached zero under high-to-extreme species diversity (Figure 3B). Under the general control model, lower destabilizing effects occurred at low species diversities ( $<50$ species). Finally, no relationship was found between stability changes and species diversity under speciation models implying niche contraction (CON1 and CON2).

\section{Relationships between structural changes and community dynamics}

We previously described the pervasive effects of different speciation models on connectance, nestedness, and modularity. These effects are governed by interaction rewiring rules subjacent to speciation models (Figure 2). Importantly, speciation-induced changes in connectance $(\Delta C)$ were strongly and negatively related to changes in modularity $(\Delta Q)$ across speciation models $\left(R^{2}=0.85\right.$ and 0.84 for EXP1 and EXP2, respectively; $R^{2}=0.77$ and 0.8 for CON1 and CON2; $P<0.001)$ with the exception of GM, the general control model $\left(R^{2}=0.007, P=0.3\right)$. On the other hand, $\triangle C$ is weakly related to changes in nestedness as described by $\triangle N O D F$ 
under niche expansion speciation models $\left(R^{2}=0.06, P=0.002\right.$ for EXP1 and $R^{2}=0.1, P=$ 0.0002 for EXP2). No significant relationship between $\triangle C$ and $\triangle N O D F$ occurred under the general control model $\left(R^{2}=0.008, P=0.26\right.$ for GM). However, the relationship between connectance and nestedness was stronger under the niche contraction speciation models $\left(R^{2}=\right.$ $0.36, P<0.001$ for EXP1 and $R^{2}=0.37, P<0.001$ for EXP2). Similar structural relationships appear to govern the effects of niche reorganization on ecological stability across speciation models.

Changes in connectance $(\Delta C)$ and modularity $(\Delta Q)$ have significant, strong and inverse effects on $\Delta \lambda_{\mathrm{R}} / S_{\mathrm{M}}$ across all speciation scenarios. Stability decreases as connectance changes increases and, conversely, increases as modularity increases. As summarized in Table 1 , the degree of increase in nestedness $(\triangle N O D F)$ decreases stability only in the general control (GM) and niche contraction speciation models (CON1 and CON2). The relationships between structural change descriptors and stability were similar between interspecific competition scenarios (M and MC) for the niche expansion models (EXP1 and EXP2) and for the general control (GM). However, under the niche contraction speciation models (CON1 and CON2), the coefficients of determination $\left(R^{2}\right)$ were consistently higher when species competed for mutualistic partners (Table 1). A positive, weak but significant relationship occurred between changes in the number of modules and stability under both niche expansion models $\left(0.11>R^{2}>0.03, P<0.05\right.$ for both EXP1 and EXP2 under all interspecific competition scenarios) and niche contraction models $\left(0.12>R^{2}>0.03, P<0.05\right.$ for both CON1 and CON2 under all interspecific competition scenarios), and no relationship between these variables was detected under the general control model GM $\left(R^{2}<0.02, P>0.33\right.$ for all interspecific competition scenarios).

\section{DISCUSSION}

Understanding how ecological interactions define the extent to which communities can incorporate new species is a central problem of ecology (Lawton 1999). Most studies of the relationship between the structure and dynamics of biodiversity to date have assumed fixed sets of species (Thompson et al. 2012). However, ecological dynamics are continuously subject to the effects of species additions and deletions (Abrams 1996; Dunne et al. 2002) and to adaptive interaction switching that maximizes fitness at the population level (Suweis et al. 2013). Models relating the biological mechanisms governing network evolution, such as adaptation and species diversification, to emerging ecological dynamics are thus required to 
improve our understanding of how the interplay between ecology and evolution shapes biodiversity (McKane and Drossel 2006; Martinez 2006). Here, we provide a first step towards formalizing a mechanistic understanding of the structural effects of niche reorganization under different speciation modes and their consequences for local stability.

Our results suggest that speciation is likely to have high-magnitude effects on the structural properties of mutualistic networks under different ecological scenarios (e.g., different interspecific competition regimes). Architectural changes imposed by niche reorganization following speciation is primarily determined by niche width variation (defined in our model by $\xi_{1}$ and $\xi_{2}$ ) but is not affected by niche overlap relationships between emerging species (defined by $\rho$ ). When emerging species undergo niche expansion (EXP1 and EXP2), mutualistic networks experience increases in connectance and nestedness, while modularity decreases (Figure 2). The pattern of higher nestedness acquisition under niche width expansion converges with the findings of a study of the addition of invasive plants to ecological networks that showed a positive relationship between the number of introduced species interactions and nestedness (Russo et al. 2014). Importantly, the magnitude of nestedness acquisition for our speciation models was higher than the magnitude reported for models of invasive species additions by Russo et al. (2014). A possible explanation for larger nestedness increases in niche expansion speciation models is that, contrary to invasion models in which introduced species establish random mutualistic interactions, emerging sister species maintain a core of common ancestral interactions that would, on average, increase the number of species interacting with subsets of the partners of other species, thereby increasing nestedness. This situation would be possible, for example, under secondary contact between phylogenetically related mutualistic species following allopatric speciation (e.g., Rich et al. 2008). Indeed, the maintenance of shared ancestral interactions between emerging species can be associated to moderate degrees of divergence in resource use as a consequence of divergent local adaptations and would be expected due to niche conservatism subjacent to vicariance and other modes of geographic speciation (Wiens 2004).

Niche width contraction after speciation (CON1 and CON2) led to modularity increases associated with decreases in connectance and lower degrees of nestedness acquisition. Increases in modularity $(\Delta \bar{Q})$ were weakly related to changes in the number of modules $(\Delta \bar{m})$ in these models, indicating a reduction in inter-modular connectivity imposed by niche width contractions (i.e., modules generally do not split but rather decrease their connectivity). Interestingly, the modularity increases in the niche contraction models were associated with an overall increase in nestedness. One possible explanation for this result is 
the rising number of specialists under CON1 and CON2, which would positively affect nestedness on average by increasing the number of species interacting with subsets of partner species that in turn interact with more generalist species. Empirical processes that can lead to the dynamics described by the speciation models CON1 and CON2 include sympatric adaptive speciation driven by frequency dependent intraspecific competition (Dieckmann et al. 2004) and ecological speciation driven by divergent natural selection between environments (Schluter 2000b; Nosil 2012), the latter of which must be followed by secondary contact. Additionally, modularity can originate from reciprocal co-evolutionary specialization between species (Thompson 2005; Guimarães et al. 2007). Although we did not explicitly model diversifying co-evolution, we would expect similar structural changes whenever reciprocal co-evolutionary specialization leading to speciation implies niche width contraction in emerging species. However, whether mutualistic coevolution promotes or restricts trait diversification, and under what circumstances, is highly controversial (Hembry et al. 2014).

The dynamical consequences of speciation in model networks primarily depend on whether niches of emerging species undergo expansions or contractions (Figure 3A). Indeed, the number of mutualistic partners held by a species can be considered a good predictor of species persistence, and the mechanisms underlying its variation have the potential to explain multiple higher order network properties (see James et al. 2012). In our results, a clear contrast appeared between recurrent destabilizing effects under niche expansion models (EXT1 and EXT2) and higher probabilities of a stable community as a result of speciationinduced niche contraction (CON1 and CON2, Figure 4). Adaptive speciation processes (Dieckmann et al. 2004) that reduce the niche width of emerging species by character displacement (Schluter 2000a) or other mechanisms, either sympatrically or allopatrically, are thus expected to be more likely to generate species that can be incorporated into existing communities. These findings suggest, intriguingly, that lineage diversity generated by adaptive radiations may be intrinsically stable, which would in part explain our ease at recognizing young adaptive radiations for what they are. On the other hand, the appearance of new species is expected to destabilize communities whenever speciation implies niche expansion, with the possible exception of megadiverse communities that would be more resilient to the addition of generalist species.

In our models, positive modularity changes were associated with increased stability (Table 1), a pattern that conflicts with the notion that modularity will often reduce stability in bipartite networks (Thébault and Fontaine 2010; Bascompte and Jordano 2014). The positive 
relationship between modularity and stability can be attributed to a reduced potential for perturbation propagation in more modular structures (Olesen et al. 2007). Therefore, considering that (i) the dynamic effects of speciation were weakly related to nestedness across speciation models and (ii) nestedness increased both under niche expansion speciation models (characterized by the average destabilizing effects of speciation) and under niche contraction speciation models (characterized by the average stabilizing effects of speciation), we hypothesize that changes in connectance and modularity are the major drivers of the dynamic consequences of speciation.

\section{Concluding remarks}

Ecological interactions affect speciation in multiple ways (McPeek 1996; Schluter 2001; Gavrilets 2004). Conversely, evolution affects niche variation and shapes patterns of specialization and generalization in ecological networks (Bascompte and Jordano 2014). A broad theoretical body addressing the effects of evolution on ecological dynamics is not currently available because systematic comparisons of studies undertaken under variable model structures involving a number of evolutionary processes are quite divergent with regard to whether evolutionary processes produce stabilizing or destabilizing effects (Brännström et al. 2012). In this study, we provide a first step toward investigating the role of speciation as a factor shaping the dynamics of ecological networks. Future studies might extend our models in any of the following ways: incorporating the traits mediating ecological interactions into speciation models; exploring the consequences of speciation in relation to interaction strengths and their corresponding stability effects; explicitly modeling species abundances; exploring alternative scenarios of niche reorganization; considering niche variation at the individual level; comparing the effects of speciation in networks depicting other types of ecological interaction; and examining the effects of cascading speciation events within ecological networks.

\section{ACKNOWLEDGEMENTS}

The São Paulo State Research Foundation (FAPESP) supported R. L. G. Raimundo (grant \#2011/13054-6), F. M. D. Marquitti (grant \#2011/11346-0), and P. R. Guimarães Jr (grant \#2009/54422-8). CAPES also provided financial support for R. L. G. Raimundo, F. M. D. 
Marquitti, and P. R. Guimarães Jr. D. H. Hembry was supported by the National Science Foundation (OISE-1159509). P. R. Guimarães Jr was also supported by CNPq.

\section{REFERENCES}

Abrams, P. A. 1996. Evolution and the consequences of species introductions and deletions. Ecology 77:1321.

Allesina, S., and S. Tang. 2012. Stability criteria for complex ecosystems. Nature 483:205208.

Almeida-Neto, M., P. Guimarães, P. R. Guimarães Jr, R. D. Loyola, and W. Ulrich. 2008. A consistent metric for nestedness analysis in ecological systems: reconciling concept and measurement. Oikos 117:1227-1239.

Anacker, B. L., and S. Y. Strauss. 2014. The geography and ecology of plant speciation: range overlap and niche divergence in sister species. Proceedings of the Royal Society (B) 81: 20132980.

Araújo, M.S., Bolnick, D.I., and Layman, C.A. 2011. The ecological causes of individual specialisation. Ecology Letters 14:948-958.

Barber, M. J. 2007. Modularity and community detection in bipartite networks. Physical Review E 76: 066102.

Bascompte, J. 2010. Structure and dynamics of ecological networks. Science 329:765-766.

Bascompte, J., and P. Jordano. 2014. Mutualistic Networks. Princeton University Press, Princeton, NJ.

Bascompte, J., P. Jordano, C. J. Melián, and J. Olesen. 2003. The nested assembly of plantanimal mutualistic networks. Proceedings of the National Academy of Sciences 100:93839387.

Bastolla, U., M. A. Fortuna, A. Pascual-García, A. Ferrera, B. Luque, and J. Bascompte. 2009. The architecture of mutualistic networks minimizes competition and increases biodiversity. Nature 458:1018-1020.

Bhattacharyay, A., and B. Drossel. 2005. Modeling coevolution and sympatric speciation of flowers and pollinators. Physica A 345:159-172.

Bolnick, D. I. 2001. Intraspecific competition favours niche width expansion in Drosophila melanogaster. Nature 410:463-466.

Brännström, Å., J. Johansson, N. Loeuille, N. Kristensen, T. A. Troost, R. H. R. Lambers, and U. Dieckmann. 2012. Modelling the ecology and evolution of communities: a review of past achievements, current efforts, and future promises. Evolutionary Ecology Research 14:601625. 
Butlin, R., A. Debelle, C. Kerth, R. R. Snook, L. W. Beukeboom, R. F. C. Cajas, W. Diao, M. E. Maan, S. Paolucci, F. J. Weissing, L. van de Zande, A. Hoikkala, E. Geuverink, J. Jennings, M. Kankare, K. E. Knott, V. I. Tyukmaeva, C. Zoumadakis, M. G. Ritchie, D. Barker, E. Immonen, M. Kirkpatrick, M. Noor, C. Macias Garcia, T. Schmitt, M. Schilthuizen, and M. C. S. Network. 2012. What do we need to know about speciation? Trends in Ecology and Evolution 27:27-39.

Dieckmann, U., M. Doebeli, J. Metz, and D. Tautz. 2004. Adaptive speciation. The Press Syndicate of the University of Cambridge, Cambridge.

Doebeli, M., and U. Dieckmann. 2000. Evolutionary branching and sympatric speciation caused by different types of ecological interactions. American Naturalist 156:S77-S101.

Dunne, J. A., R. J. Williams, and N. D. Martinez. 2002. Food-web structure and network theory: the role of connectance and size. Proceedings of the National Academy of Sciences 99:12917-12922.

Elton, C. S. 1958. Ecology of invasions by animals and plants. Chapman \& Hall, London.

Fortuna, M. A., D. B. Stouffer, J. Olesen, P. Jordano, D. Mouillot, B. R. Krasnov, R. Poulin, and J. Bascompte. 2010. Nestedness versus modularity in ecological networks: two sides of the same coin? Journal of Animal Ecology 79:811-817.

Gavrilets, S. 2004. Fitness landscapes and the origin of species. Princeton University Press, Princeton, NJ.

Guimarães, P.R., Jr, V. Rico-Gray, P. S. Oliveira, T. J. Izzo, S. F. F. dos Reis, and J. N. Thompson. (2007). Interaction intimacy affects structure and coevolutionary dynamics in mutualistic networks. Current Biology 17:1797-1803.

Harmon, L.J., Mathews, B., Des Roches, S., Chase, J. M., Shurin, J. B., and Schluter, D. 2009. Evolutionary diversification in stickleback affects ecosystem functioning. Nature 458:1167-1170.

Hembry, D.H., Yoder, J.B., and Goodman, K.R. 2014. Coevolution and the diversification of life. American Naturalist 184:425-438.

Hoskin, C.J., M. Higgie, K.R. McDonald, and C. Moritz. 2005. Reinforcement drives rapid allopatric speciation. Nature 437: 1353-1356.

James, A., J. W. Pitchford, and M. J. Plank. 2012. Disentangling nestedness from models of ecological complexity. Nature 487:227-230.

Jordano, P., J. Bascompte, and J. Olesen. 2003. Invariant properties in coevolutionary networks of plant-animal interactions. Ecology Letters 6:69-81.

Lawton, J. H. 1999. Are there general laws in Ecology? Oikos 84:177-192.

Loeuille, N. 2010. Influence of evolution on the stability of ecological communities. Ecology Letters 13:1536-1545.

Losos, J. B., and D. L. Mahler. 2010. Adaptive radiation: the interaction of ecological 
opportunity, adaptation, and speciation. In M.A. Bell, D.J. Futuyma, W.F. Eanes, and J.S. Levinton, Eds. Evolution since Darwin: the first 150 Years. Sinauer Assoc., Sunderland, MA.

MacArthur, R. 1955. Fluctuations of animal populations and a measure of community stability. Ecology 36:533-536.

Marquitti, F.M.D., Guimarães, P.R., Jr, Pires, M.M. \& Bittencourt, L.F. 2014. MODULAR: software for the autonomous computation of modularity in large network sets. Ecography 37:221-224.

Martinez, N. D. 2006. Network evolution: exploring the change and adaptation of complex ecological systems over deep time. In Pascual, M., and Dunne, J. A. Eds. Ecological networks: linking structure to dynamics in food webs, Oxford University Press, Oxford.

May, R. M. 1973. Qualitative stability in model ecosystems. Ecology 54:638-641.

McCann, K. S. 2000. The diversity-stability debate. Nature 405:228-233.

McKane, A. J., and B. Drossel. 2006. Ecological networks as evolving, adaptive systems. In M. Pascual and J. A. Dunne, Eds. Ecological networks: linking structure to dynamics in food webs, Oxford University Press, Oxford.

McPeek, M. A. 1996. Linking local species interactions to rates of speciation in communities. Ecology 1355-1366.

Nosil, P. 2012. Ecological speciation. Oxford University Press, Oxford.

Olesen, J., J. Bascompte, Y. L. Dupont, and P. Jordano. 2007. The modularity of pollination networks. Proceedings of the National Academy of Sciences 104:19891.

Ollerton, J. 2006. "Biological barter": patterns of specialization compared across different mutualisms. In: Waser, N. M., and Ollerton, J., Eds. Plant pollinator interactions: from specialization to generalization. University of Chicago Press, Chicago.

Raimundo, R.L.G., J. P. Gibert, D. H. Hembry, and P. R. Guimarães, Jr. 2014. Conflicting selection in the course of adaptive diversification: the interplay between mutualism and intraspecific competition. American Naturalist 183:363-375.

Robinson, B. W., and D. S. Wilson. 1998. Optimal foraging, specialization, and a solution to Liem's paradox. American Naturalist 151:223-235.

Russo, L., J. J. Memmott, D. Montoya, K. Shea, and Y. M. Buckley. 2014. Patterns of introduced species interactions affect multiple aspects of network structure in plant-pollinator communities. Ecology 95:2953-2963.

Schluter, D. 2000a. Ecological character displacement in adaptive radiation. American Naturalist 156:S4-S16.

Schluter, D. 2000b. The ecology of adaptive radiation. Oxford University Press, Oxford.

Schluter, D. 2001. Ecology and the origin of species. Trends in Ecology and Evolution $16: 372-380$. 
Schluter, D. 2009. Evidence for ecological speciation and its alternative. Science 323:737741.

Schluter, D., and G. L. Conte. 2009. Genetics and ecological speciation. Proceedings of the National Academy of Sciences 106:9955.

Stoline, M. R. 1981. The status of multiple comparisons - simultaneous estimation of all pairwise comparisons in one-way Anova designs. American Statistician 35:134-141.

Suweis, S., F. Simini, J. R. Banavar, and A. Maritan. 2013. Emergence of structural and dynamical properties of ecological mutualistic networks. Nature 500:449-452.

Svanbäck, R., and D. I. Bolnick. 2007. Intraspecific competition drives increased resource use diversity within a natural population. Proceeding of the Royal Society (B) 274:839-844.

Trøjelsgaard, K., Báez, M., Espalder, X., Nogales, M., Oromí, P., La Roche, F., and Olesen, J. M. 2013. Island biogeography of mutualistic interaction networks. Journal of Biogeography 40: 2020-2031.

Thébault, E., and C. Fontaine. 2010. Stability of ecological communities and the architecture of mutualistic and trophic networks. Science 329:853-856.

Thompson, J. N. 2005. The geographic mosaic of coevolution. The University of Chicago Press, Chicago.

Thompson, R. M., U. Brose, J. A. Dunne, R. O. J. Hall, S. Hladyz, R. L. Kitching, N. D. Martinez, H. Rantala, T. N. Romanuk, D. B. Stouffer, and J. M. Tylianakis. 2012. Food webs: reconciling the structure and function of biodiversity. Trends in Ecology and Evolution 27:689-697.

Vellend, M. 2010. Conceptual synthesis in community ecology. The Quarterly Review of Biology 85:183-206.

Wiens, J. J. 2004. Speciation and ecology revisited: phylogenetic niche conservatism and the origin of species. Evolution 58:193-197. 


\section{FIGURE CAPTIONS}

Figure 1. Niche organization under different models of speciation, as described by $\xi_{1}$ and $\xi_{2}$ (the effect of speciation on niche width; i.e., whether emerging species gain or loose links) and $\rho$ (the effect on niche overlap; i.e., how link additions or deletions are correlated). The number of links in emerging species expands when $\xi_{1}$ or $\xi_{2}=1$, remains constant when $\xi_{1}$ or $\xi_{2}$ $=0$, and contracts when $\xi_{1}$ or $\xi_{2}=-1$. Interactions can be added or subtracted with negative correlation $\rho=-1$, or without correlation $\rho=0$. (A) Initial conditions showing the bipartite network depicting an assemblage and a randomly sampled species, $E_{1}$, undergoing speciation. (B-C) Niche contraction scenarios in which $E_{1}$ and $E_{2}$ lose negatively correlated links (CON1) or uncorrelated links (CON2). (D) A general control model (GM) in which a species, $E_{2}$, with the same number of interactions as $E_{1}$ is added to the community with randomized interactions. (E-F) Niche expansion scenarios in which $E_{1}$ and $E_{2}$ gain links that are negatively correlated (EXP1) or uncorrelated (EXP2).

Figure 2. Structural changes arising under different speciation models. Panels show speciation-induced variation in (A) the number of links held by emerging species in relation to the ancestor species $(\Delta k),(\mathbf{B})$ Connectance $(\Delta C),(\mathbf{C})$ Nestedness $(\triangle N O D F)$, and (D) Modularity $(\Delta Q)$. The white lines in the boxplots indicate median values. The results for each speciation model refer to 100 simulations for each of the 71 mutualistic networks summarized in Table S1 (supplementary information).

Figure 3. Dynamic consequences of different models of speciation. (A) Characterization of stability variation per species $\left(\Delta \lambda_{\mathrm{R}} / S_{\mathrm{M}}\right)$ across the speciation models described in Figure 1. (B) Mean stability change of mutualistic networks in relation to species richness across speciation models and interspecific competition scenarios. Results refer to 50 simulation replicates for 71 mutualistic networks and each combination of speciation model and competition scenario. Green dots indicate high-intimacy mutualisms, whereas yellow dots indicate low-intimacy mutualisms. $\mathrm{M}$ indicates models assuming no interspecific competition, and $\mathrm{MC}$ refers to simulations in which species compete for mutualistic partners.

Figure 4. Percentage of simulations in which $\Delta \lambda_{R}<0$ (i.e., when speciation imposes a stabilizing effect on population dynamics). Each panel shows the results for 50 simulation replicates for each of the 71 mutualistic networks used to parameterize the models. Green dots indicate high-intimacy mutualisms, whereas yellow dots indicate low-intimacy mutualisms. $\mathrm{M}$ indicates models assuming no interspecific competition, and $\mathrm{MC}$ refers to simulations in which species compete for mutualistic partners. 
167

Figure 1

A

Initial condition

P1

P2

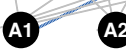

P3

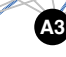

B

Model CON1 $\left(\xi_{1}=\xi_{2}=-1, \rho=-1\right)$

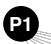

(2) P3
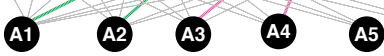

C

Model CON2 $\left(\xi_{1}=\xi_{2}=-1, \rho=0\right)$

P1 22 P3

(A)

D

Model GM $\left(\xi_{1}=\xi_{2}=0, \rho=0\right)$

(1)

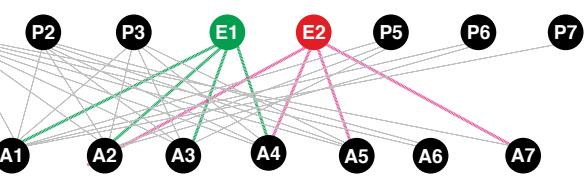

$\mathbf{E}$

Model EXP1 $\left(\xi_{1}=\xi_{2}=1, \rho=-1\right)$

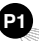

P2 P3

A1

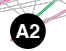

A6

F

Model EXP2 $\left(\xi_{1}=\xi_{2}=1, \rho=0\right)$

P1

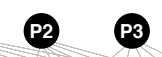

(A)
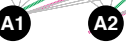
Figure 2
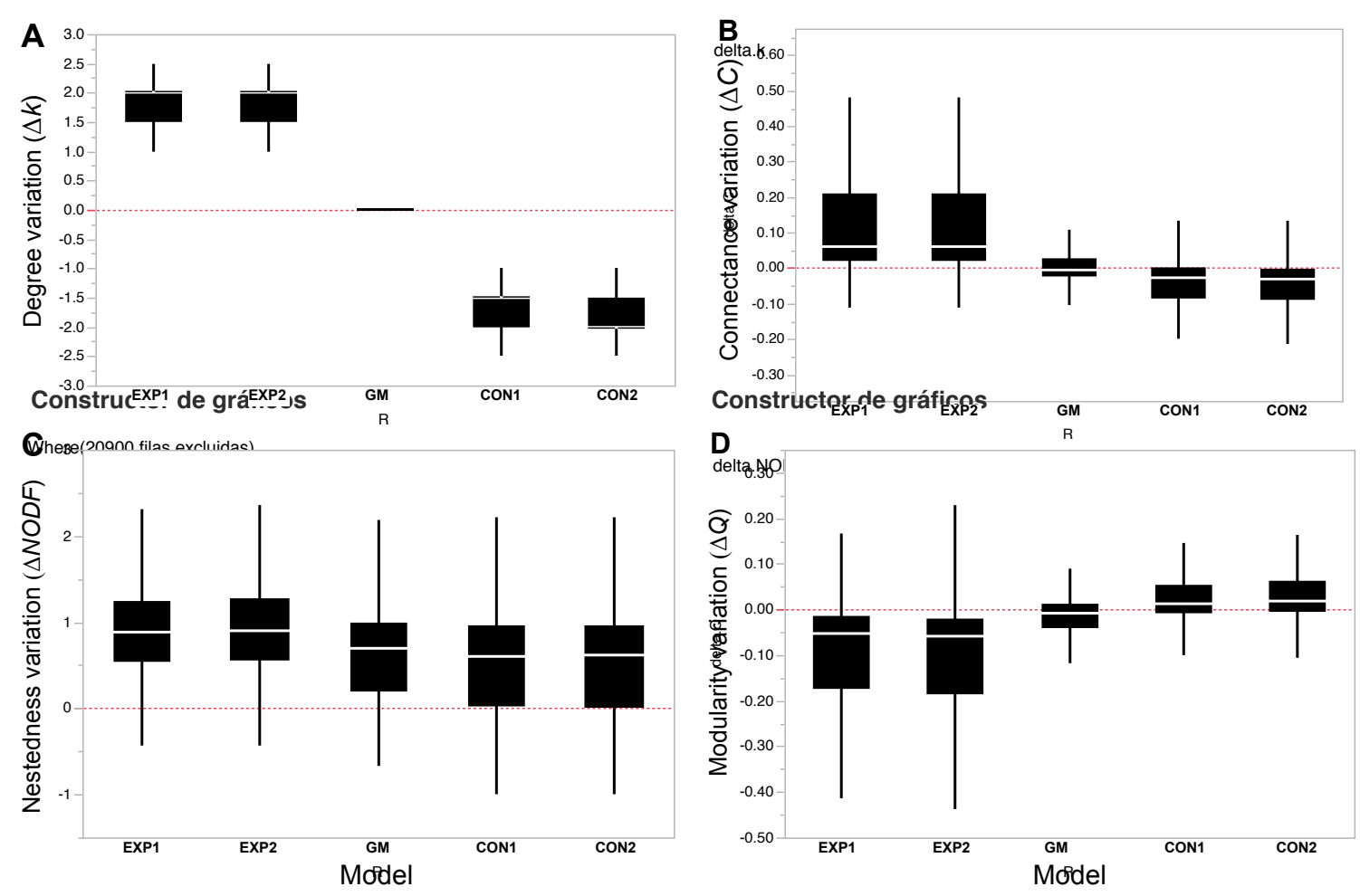
Figure 3
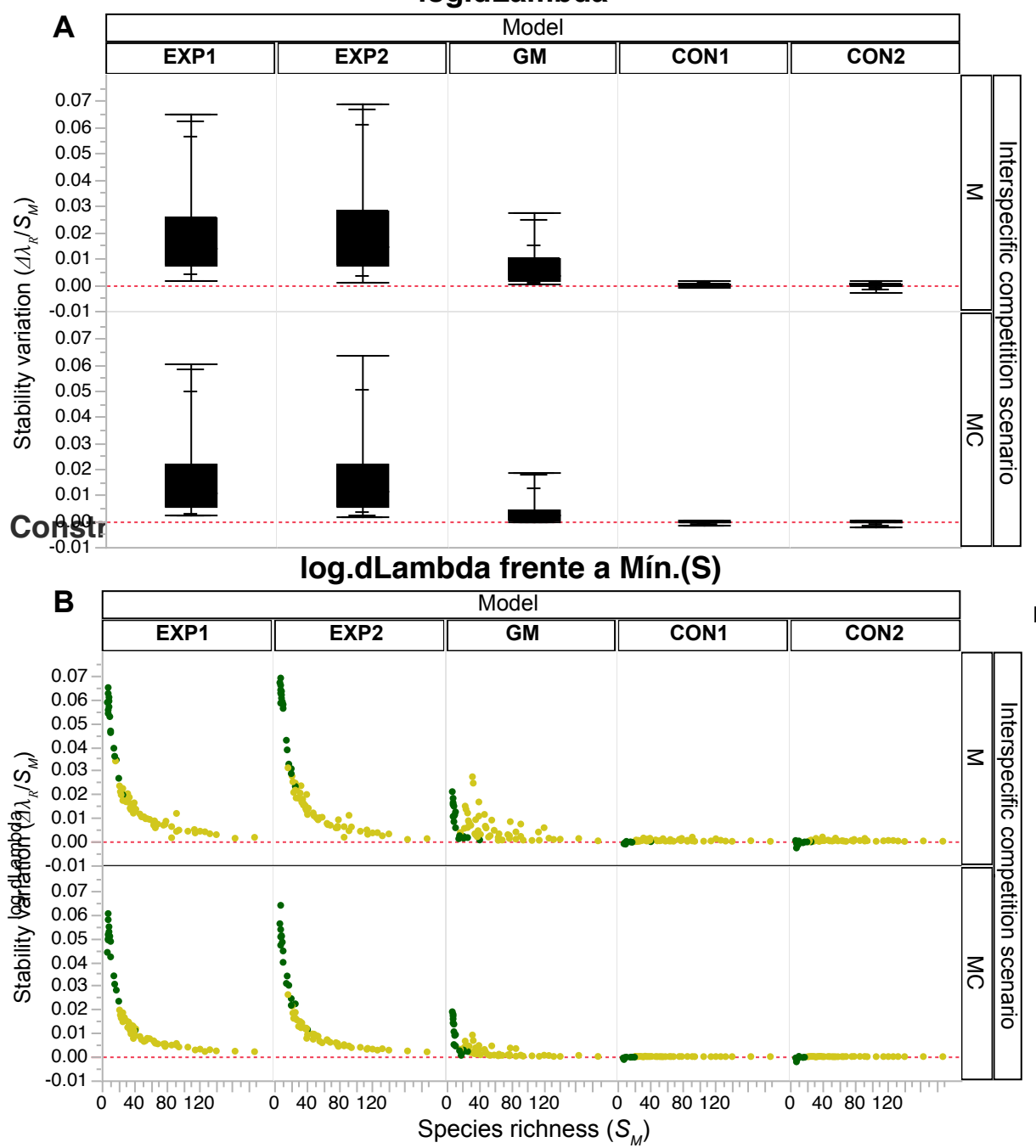
Figure 4

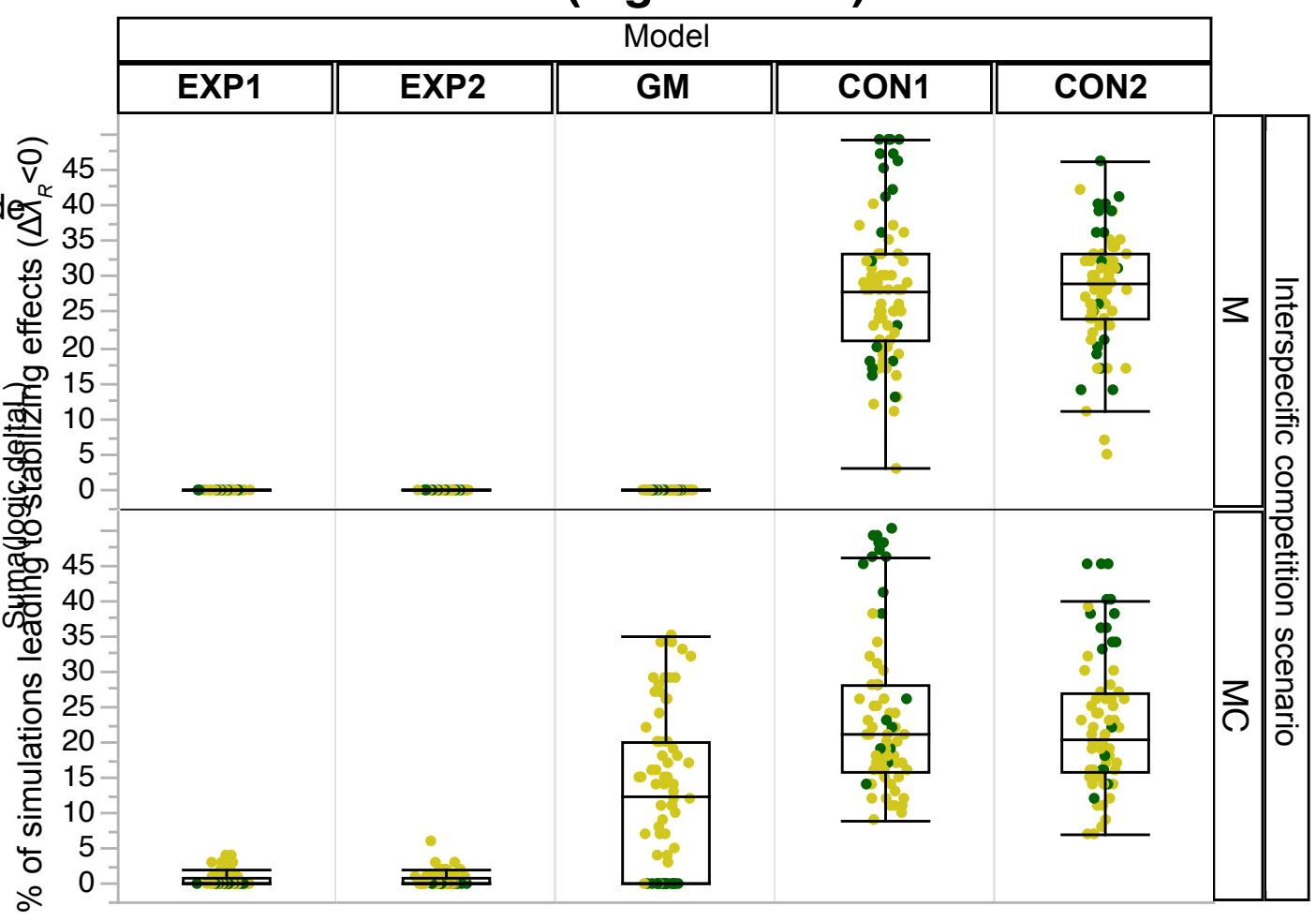


Table 1. Coefficient of determination $\left(R^{2}\right)$ of single-variable regressions in which changes in structural descriptors were used as predictor variables for variation in the stability $\left(\Delta \lambda_{R} / S_{M}\right)$ of 71 model mutualistic networks after speciation. Speciation models are described in Figure 1. Scenarios refer to assumptions regarding interspecific competition: it can either be absent (M), or species can compete for mutualists (MC). Speciation-induced changes in network structure are described by $\triangle C$ (connectance), $\triangle N O D F$ (nestedness), and $\triangle Q$ (modularity). Each regression point is the mean property value for 50 simulation replicates per network/model $/$ scenario. The symbol * indicates $\mathrm{P}<0.05$, whereas unmarked values are not significant.

\begin{tabular}{lcccccccccc}
\hline Models & \multicolumn{2}{c}{ EXP1 } & \multicolumn{2}{c}{ EXP2 } & \multicolumn{2}{c}{ GM } & \multicolumn{2}{c}{ CON1 } & \multicolumn{2}{c}{ CON2 } \\
\hline Scenarios & M & MC & M & MC & M & MC & M & MC & M & MC \\
\hline$\Delta C$ & $0.69^{*}$ & $0.71^{*}$ & $0.68^{*}$ & $0.69^{*}$ & 0.03 & 0.02 & $0.48^{*}$ & $0.69^{*}$ & $0.42^{*}$ & $0.61^{*}$ \\
$\Delta N O D F$ & 0.00 & 0.00 & 0.00 & 0.00 & $0.13^{*}$ & $0.14^{*}$ & $0.17^{*}$ & $0.32^{*}$ & $0.17^{*}$ & $0.27^{*}$ \\
$\Delta Q$ & $0.86^{*}$ & $0.87^{*}$ & $0.87^{*}$ & $0.87^{*}$ & 0.02 & 0.00 & $0.5^{*}$ & $0.77^{*}$ & $0.41^{*}$ & $0.71^{*}$ \\
\hline
\end{tabular}




\title{
SUPPLEMENTARY INFORMATION
}

\section{Speciation, niche reorganization, and the stability of mutualistic networks}

\author{
Rafael L. G. Raimundo, David. H. Hembry, Flavia M. D. Marquitti \&
}

Paulo R. Guimarães Jr

Table S1. Empirical mutualistic networks used to parameterize simulations that investigate the effects of different speciation models on network structure and dynamics. L, Low interaction intimacy. H, High interaction intimacy. AP, Protection mutualisms between plants with extrafloral nectaries and ants. PP, Mutualisms between flowering plants and their animal pollinators. PS, Mutualisms between zoochoric plants and their animal seed dispersers. CC, Marine mutualisms between cleaner species of fishes and shrimps and their client fishes. AF, Obligate marine mutualisms between anemone fish and their host sea anemones. MAP, Mutualisms between myrmecophyte ants and their host plants.

\begin{tabular}{|c|c|c|c|c|c|}
\hline ID & Intimacy & System & Locality & Country & Reference \\
\hline tripul & $\mathrm{L}$ & AP & Cape Tripulation & Australia & Blüthgen et al. 2004 \\
\hline benit & $\mathrm{L}$ & AP & San Benito & Mexico & Guimarães et al. 2007b \\
\hline manch & $\mathrm{L}$ & AP & La Mancha & Mexico & Guimarães et al. 2007b \\
\hline xalap & $\mathrm{L}$ & AP & Parque Clavijero & Mexico & Guimarães et al. $2007 \mathrm{~b}$ \\
\hline zapot & $\mathrm{L}$ & AP & Valle de Zapotitlan & Mexico & Guimarães et al. 2007b \\
\hline arroyo 1 & $\mathrm{~L}$ & PP & Cordón del Cepo & Chile & Arroyo et al. 1982 \\
\hline arroyo 2 & $\mathrm{~L}$ & $\mathrm{PP}$ & Cordón del Cepo & Chile & Arroyo et al. 1982 \\
\hline arroyo3 & $\mathrm{L}$ & $\mathrm{PP}$ & Cordón del Cepo & Chile & Arroyo et al. 1982 \\
\hline barret & $\mathrm{L}$ & PP & New Brunswick & Canada & Barrett and Helenurm 1987 \\
\hline bezerr & $\mathrm{L}$ & $\mathrm{PP}$ & Catimbau Park & Brazil & Bezerra et al. 2009 \\
\hline dupont & $\mathrm{L}$ & PP & Tenerife & Spain & Dupont and Hansen 2003 \\
\hline elberl & $\mathrm{L}$ & PP & Latnjajaure & Sweden & Elberling and Olesen 1999 \\
\hline hockin & $\mathrm{L}$ & $\mathrm{PP}$ & Lake Hazen & Canada & Hocking 1968 \\
\hline kaiser & $\mathrm{L}$ & PP & BRG National Park & Mauritius & Kaiser-Bunbury et al. 2010 \\
\hline inouye & $\mathrm{L}$ & PP & Kosciusko Park & Australia & Inouye and Pyke 1988 \\
\hline medan 1 & $\mathrm{~L}$ & PP & Laguna Diamante & Argentina & Medan et al. 2002 \\
\hline medan2 & $\mathrm{L}$ & PP & Rio Blanco & Argentina & Medan et al. 2002 \\
\hline mosqui & $\mathrm{L}$ & PP & Melville Island & Canada & Mosquin et al. 1967 \\
\hline olesen & $\mathrm{L}$ & PP & Aigrettes Island & Mauritius & Olesen et al. 2002 \\
\hline olesen & $\mathrm{L}$ & $\mathrm{PP}$ & Flores Island & Portugal & Olesen et al. 2002 \\
\hline ollert & $\mathrm{L}$ & $\mathrm{PP}$ & Wahroonga & South Africa & Ollerton et al. 2003 \\
\hline ramire & $\mathrm{L}$ & $\mathrm{PP}$ & Calabozo & Venezuela & Ramírez 2004 \\
\hline santos & $\mathrm{L}$ & $\mathrm{PP}$ & Itatim & Brazil & Santos et al. 2010 \\
\hline schems & $\mathrm{L}$ & $\mathrm{PP}$ & Brownfield Woods & United States & Schemske et al. 1977 \\
\hline small & $\mathrm{L}$ & $\mathrm{PP}$ & Dolman Ridge Road & Canada & Small 1976 \\
\hline vazqu1 & $\mathrm{L}$ & PP & Arroyo Goye & Argentina & Vázquez and Simberloff 2003 \\
\hline vazqu2 & $\mathrm{L}$ & $\mathrm{PP}$ & Cerro Lopez & Argentina & Vázquez and Simberloff 2003 \\
\hline vazqu3 & $\mathrm{L}$ & PP & Llao Llao & Argentina & Vázquez and Simberloff 2003 \\
\hline
\end{tabular}


Table S1 (continued)

\begin{tabular}{|c|c|c|c|c|c|}
\hline vazqu4 & $\mathrm{L}$ & $\mathrm{PP}$ & Mascardi & Argentina & Vázquez and Simberloff 2003 \\
\hline vazqu5 & $\mathrm{L}$ & $\mathrm{PP}$ & Quetrihue & Argentina & Vázquez and Simberloff 2003 \\
\hline dicks 1 & $\mathrm{~L}$ & PP & Norfolk & UK & Dicks et al. 2002 \\
\hline dicks2 & $\mathrm{L}$ & $\mathrm{PP}$ & Norfolk & UK & Dicks et al. 2002 \\
\hline primac & $\mathrm{L}$ & $\mathrm{PP}$ & AP National Park & N. Zealand & Primack 1983 \\
\hline baird & $\mathrm{L}$ & PS & Princeton & USA & Baird 1980 \\
\hline beehle & $\mathrm{L}$ & PS & Mount Missi & P. N. Guinea & Beehler 1983 \\
\hline carlo1 & $\mathrm{L}$ & PS & Caguana & Puerto Rico & Carlo et al. 2003 \\
\hline carlo2 & $\mathrm{L}$ & PS & Cialitos & Puerto Rico & Carlo et al. 2003 \\
\hline carlo3 & $\mathrm{L}$ & PS & Cordillera & Puerto Rico & Carlo et al. 2003 \\
\hline carlo4 & $\mathrm{L}$ & PS & Fronton & Puerto Rico & Carlo et al. 2003 \\
\hline galett & $\mathrm{L}$ & PS & Campinas & Brazil & Galetti and Pizo 1996 \\
\hline pouli1 & $\mathrm{L}$ & PS & Barro Colorado Island & Panamá & Poulin et al. 1999 \\
\hline pouli2 & $\mathrm{L}$ & PS & Soberania Park & Panamá & Poulin et al. 1999 \\
\hline schleu & $\mathrm{L}$ & PS & Kakamega Forest & Kenya & Schleuning et al. 2011 \\
\hline crome & $\mathrm{L}$ & PS & LC Mission Beach & Australia & Crome 1975 \\
\hline sorens & $\mathrm{L}$ & PS & Oxford & UK & Sorensen 1981 \\
\hline jordan & $\mathrm{L}$ & PS & Hato Raton & Spain & Jordano 1985 \\
\hline kantak & $\mathrm{L}$ & PS & Xpujil & Mexico & Kantak 1979 \\
\hline lamber & $\mathrm{L}$ & PS & Kuala Lompat & Malaysia & Lambert 1987 \\
\hline mack1 & $\mathrm{L}$ & PS & CMBR Station & P. New Guinea & Mack 1994 \\
\hline donatt & $\mathrm{L}$ & PS & Rio Negro & Brazil & Donatti et al. 2011 \\
\hline john & $\mathrm{L}$ & $\mathrm{CC}$ & Saint Crox & Virgin Islands & Johnson and Ruben 1988 \\
\hline sazima & $\mathrm{L}$ & $\mathrm{CC}$ & Abrolhos & Brazil & Guimarães et al. 2007a \\
\hline wick & $\mathrm{L}$ & $\mathrm{CC}$ & Bonaire & Neth. Antilles & Wicksten 1998 \\
\hline riccil & $\mathrm{H}$ & $\mathrm{AF}$ & Bahowo & Indonesia & Ricciardi et al. 2010 \\
\hline ricci2 & $\mathrm{H}$ & $\mathrm{AF}$ & Bualo & Indonesia & Ricciardi et al. 2010 \\
\hline ricci3 & $\mathrm{H}$ & $\mathrm{AF}$ & Fukui & Indonesia & Ricciardi et al. 2010 \\
\hline ricci4 & $\mathrm{H}$ & $\mathrm{AF}$ & Jalan Masuk & Indonesia & Ricciardi et al. 2010 \\
\hline ricci5 & $\mathrm{H}$ & $\mathrm{AF}$ & Kasegaran Point & Indonesia & Ricciardi et al. 2010 \\
\hline ricc6 & $\mathrm{H}$ & $\mathrm{AF}$ & Likuan & Indonesia & Ricciardi et al. 2010 \\
\hline $\operatorname{ricc} 7$ & $\mathrm{H}$ & $\mathrm{AF}$ & Mandolin & Indonesia & Ricciardi et al. 2010 \\
\hline $\operatorname{ricc} 8$ & $\mathrm{H}$ & $\mathrm{AF}$ & Mike's Point & Indonesia & Ricciardi et al. 2010 \\
\hline ricc9 & $\mathrm{H}$ & $\mathrm{AF}$ & Sachiko & Indonesia & Ricciardi et al. 2010 \\
\hline ricc 10 & $\mathrm{H}$ & $\mathrm{AF}$ & Tanjung Kopi & Indonesia & Ricciardi et al. 2010 \\
\hline ricc11 & $\mathrm{H}$ & $\mathrm{AF}$ & Tanjung Pisok & Indonesia & Ricciardi et al. 2010 \\
\hline david & $\mathrm{H}$ & MAP & Manu Park & Peru & Davidson et al. 1989 \\
\hline izzomt1 & $\mathrm{H}$ & MAP & Amazonas State & Brazil & Guimarães et al. 2007b \\
\hline izzomt2 & $\mathrm{H}$ & MAP & Amazonas State & Brazil & Guimarães et al. 2007b \\
\hline izzomt3 & $\mathrm{H}$ & MAP & Amazonas State & Brazil & Guimarães et al. 2007b \\
\hline izzomt4 & $\mathrm{H}$ & MAP & Amazonas State & Brazil & Guimarães et al. 2007b \\
\hline izzomt5 & $\mathrm{H}$ & MAP & Amazonas State & Brazil & Guimarães et al. 2007b \\
\hline fonse & $\mathrm{H}$ & MAP & Manaus & Brazil & Fonseca and Ganade 1996 \\
\hline
\end{tabular}




\section{REFERENCES CITED IN THE SUPPORTING INFORMATION}

Arroyo, M. T. K., R. Primack, and J. Armesto. 1982. Community studies in pollination ecology in the high temperate Andes of central Chile. I. Pollination mechanisms and altitudinal variation. American Journal of Botany 69:82-97.

Baird, J. W. 1980. The selection and use of fruit by birds in an eastern forest. The Wilson Bulletin 63-73.

Barrett, S., and K. Helenurm. 1987. The reproductive biology of boreal forest herbs. I. Breeding systems and pollination. Canadian Journal of Botany 65:2036-2046.

Beehler, B. 1983. Frugivory and polygamy in birds of paradise. The Auk 100:1-12.

Bezerra, E. L. S., I. C. Machado, and M. A. R. Mello. 2009. Pollination networks of oilflowers: a tiny world within the smallest of all worlds. Journal of Animal Ecology 78:10961101.

Blüthgen, N., N. E. Stork, and K. Fiedler. 2004. Bottom-up control and co-occurrence in complex communities: honeydew and nectar determine a rainforest ant mosaic. Oikos 106:344-358.

Carlo, T., J. A. Collazo, and M. J. Groom. 2003. Avian fruit preferences across a Puerto Rican forested landscape: pattern consistency and implications for seed removal. Oecologia 134:119-131.

Crome, F. 1975. The ecology of fruit pigeons in tropical northern Queensland. Wildlife Research 2:155-185.

Davidson, D., R. Snelling, and J. Longino. 1989. Competition among ants for myrmecophytes and the significance of plant trichomes. Biotropica 21:64-73.

Dicks, L. V., S. A. Corbet, and R. F. Pywell. 2002. Compartimentalization in plant-insect flower visitor web. Journal of Animal Ecology 71:32-43.

Donatti, C. I., P. R. Guimarães Jr, M. Galetti, M. A. Pizo, F. M. D. Marquitti, and R. Dirzo. 2011. Analysis of a hyper-diverse seed dispersal network: modularity and underlying mechanisms. Ecology Letters 14:773-781.

Dupont, Y., and D. Hansen. 2003. Structure of a plant-flower-visitor network in the highaltitude sub-alpine desert of Tenerife, Canary Islands. Ecography 26:301-310.

Elberling, H., and J. Olesen. 1999. The structure of a high latitude plant-flower visitor system: the dominance of flies. Ecography 22:314-323.

Fonseca, C. R., and G. Ganade. 1996. Asymmetries, compartments and null interactions in an Amazonian ant-plant community. Journal of Animal Ecology 65:339-347.

Galetti, M., and M. Pizo. 1996. Fruit eating by birds in a forest fragment in Southeastern Brazil. Ararajuba 4:71-79. 
Guimarães, P. R., Jr, C. Sazima, S. F. F. Dos Reis, and I. Sazima. 2007a. The nested structure of marine cleaning symbiosis: is it like flowers and bees? Biology Letters 3:51-54.

Guimarães, P. R., Jr, V. Rico-Gray, P. S. Oliveira, T. J. Izzo, S. F. F. Dos Reis, and J. N. Thompson. 2007b. Interaction intimacy affects structure and coevolutionary dynamics in mutualistic networks. Current Biology 17:1797-1803.

Hocking, B. 1968. Insect-flower associations in high Arctic with special reference to nectar. Oikos 19:359-388.

Inouye, D., and G. Pyke. 1988. Pollination biology in the Snowy Mountains of Australia comparisons with Montane Colorado, USA. Australian Journal of Ecology 13:191-210.

Johnson, W. S., and P. Ruben. 1988. Cleaning behavior of Bodianus rufus, Thalassoma bifasciatum, Gobiosoma evelynae, and Periclimenes pedersoni along a depth gradient at Salt River Submarine Canyon, St Croix. Environmental Biology of Fishes 23:225-232.

Jordano, P. 1985. El ciclo anual de los paseriformes frugívoros en el matorral mediterráneo del sur de España: importancia de su invernada y variaciones interanuales. Ardeola 32:69-94.

Kaiser-Bunbury, C. N., S. Muff, J. J. Memmott, C. B. Mueller, and A. Caflisch. 2010. The robustness of pollination networks to the loss of species and interactions: a quantitative approach incorporating pollinator behaviour. Ecology Letters 13:442-452.

Kantak, G. E. 1979. Observations on some fruit-eating birds in Mexico. The Auk 96:183-186.

Lambert, F. R. 1987. Fig-eating and seed dispersal by birds in a Malaysian lowland rain forest. Journal of Tropical Ecology 5:401-412.

Mack, A. L. 1994. Notes on the nests and eggs of some birds at the Crater Mountain Research Station, Papua New Guinea. Bulletin of the British Ornithologists' Club 114:176-181.

Medan, D., N. Montaldo, M. Devoto, A. Mantese, V. Vasellati, and N. Bartoloni. 2002. Plantpollinator relationships at two altitudes in the Andes of Mendoza, Argentina. Arctic, Antarctic, and Alpine Research 34:233-241.

Mosquin, T., J. E. H. Martin, and J. Martin. 1967. Observations on the pollination biology of plants on Melville Island, NWT, Canada. Canadian Field Naturalist 81: 201-205.

Olesen, J., L. I. Eskildsen, and S. Venkatasamy. 2002. Invasion of pollination networks on oceanic islands: importance of invader complexes and endemic super generalists. Diversity and Distributions 8:181-192.

Ollerton, J., S. D. Johnson, L. Cranmer, and S. Kellie. 2003. The pollination ecology of an assemblage of grassland asclepiads in South Africa. Annals of Botany 92:807-834.

Poulin, B., Poulin, B., S. J. Wright, S. J. Wright, G. Lefebvre, G. Lefebvre, and O. Calderon. 1999. Interspecific synchrony and asynchrony in the fruiting phenologies of congeneric birddispersed plants in Panama. Journal of Tropical Ecology 15:213-227. 
Primack, R. B.1983. Insect pollination in the New Zealand mountain flora. New Zealand Journal of Botany 21:317-333.

Ramírez, N. 2004. Ecology of pollination in a tropical Venezuelan savanna. Plant Ecology 173:171-189.

Ricciardi, F., M. Boyer, and J. Ollerton. 2010. Assemblage and interaction structure of the anemonefish-anemone mutualism across the Manado region of Sulawesi, Indonesia. Environmental Biology of Fishes 87:333-347.

Santos, G. M. de M., C. M. L. Aguiar, and M. A. R. Mello. 2010. Flower-visiting guild associated with the Caatinga flora: trophic interaction networks formed by social bees and social wasps with plants. Apidologie 41:466-475.

Schemske, D. W., M. F. Wilson, M. N. Melampy, L. J. Miller, L. Verner, K. M. Schemske, and L. B. Best. 1977. Flowering ecology of some spring woodland herbs. Ecology 59:351366.

Schleuning, M., N. Blüthgen, M. Flörchinger, and J. Braun. 2011. Specialization and interaction strength in a tropical plant-frugivore network differ among forest strata. Ecology 92: $26-36$.

Small, E. 1976. Insect pollinators of the Mer Bleue peat bog of Ottawa. Canadian Field Naturalist 90:22-28.

Sorensen, A. E. 1981. Interactions between birds and fruit in a temperate woodland. Oecologia 50:242-249.

Vázquez, D. P., and D. Simberloff. 2003. Changes in interaction biodiversity induced by an introduced ungulate. Ecology Letters 6:1077-1083.

Wicksten, M. K. 1998. Behaviour of cleaners and their client fishes at Bonaire, Netherlands Antilles. Journal of Natural History 32:13-30. 


\section{CONSIDERAÇÕES FINAIS}

A compreensão mecanística sobre as origens e a manutenção da biodiversidade requer abordagens que integrem as teorias ecológicas e evolutivas com base em dados empíricos, como fizemos aqui ao modelar dinâmicas adaptativas de interações ecológicas usando informações sobre a organização e história natural de assembleias mutualistas. Os resultados desta Tese apoiam a ideia de que diferentes formas de seleção natural impostas por interações ecológicas, ou sobre elas atuantes, constituem forças modeladoras fundamentais que governam a estrutura, a dinâmica e a diversificação de redes mutualistas.

\section{Interações ecológicas e diversificação adaptativa}

No Capítulo 2, desenvolvemos modelos de especiação adaptativa que incorporam diferentes tipos de interações ecológicas e exploram suas implicações para a diversificação fenotípica e especiação adaptativa. Nossa abordagem representa uma contribuição original, pois ilustra a relevância de (i) estudarmos regimes disruptivos promotores de especiação competitiva no contexto comunitário mais amplo no qual inserem-se as populações potencialmente divergentes e (ii) considerarmos a variabilidade natural nas formas de cada tipo de interação ecológica ou, em outras palavras, reconhecermos o lugar central da história natural na modelagem ecológica e evolutiva. Com a incorporação desses dois componentes, o debate sobre especiação simpátrica pode transcender a dicotomia corrente entre sua plausibilidade teórica e a falta de registros empíricos, para gerar modelos capazes de melhor delimitar as circunstâncias ecológicas que podem impulsioná-la. No caso de mutualismos, ajudamos a constituir essa delimitação de pelo menos duas maneiras.

Primeiro, mostramos que diferentes graus de diversificação, desde polimorfismos até a especiação e irradiações adaptativas, podem emergir a partir dos mesmos mecanismos microevolutivos gerados por interações ecológicas, ou seja, diferentes padrões de diversificação podem ser compreendidos como expressões dos mesmos processos adaptativos interagindo de maneiras distintas. Dessa forma, apoiamos a noção de que a diversificação fenotípica é, em parte, determinada pelo resultado de pressões seletivas conflitantes impostas por diferentes tipos de interações ecológicas. Especificamente, nossos resultados sugerem que mutualismos caracterizados por congruência de traços devem frequentemente impor seleção estabilizadora e, como consequência, diminuir ou mesmo neutralizar os efeitos 
diversificadores decorrentes da seleção disruptiva oriunda da competição intraespecífica dependente de frequência.

Segundo, mostramos que o grau possível de diversificação adaptativa depende da intimidade de interação, com a diversificação adaptativa sendo pouco provável em mutualismos de baixa intimidade, nas quais altos números de parceiros mutualistas individuais resultam em desajustes fenotípicos desproporcionalmente mais frequentes e de maior magnitude para fenótipos extremos, fenômeno que é minimizado em mutualismos de alta intimidade. Esses resultados teóricos, que são robustos sob o relaxamento de diferentes pressupostos críticos, contrastam fortemente com os padrões de riqueza observados

mutualismos naturais, já que sistemas de baixa intimidade são, em média, uma ordem de grandeza mais ricos que os de alta intimidade. Sugerimos que outros processos são necessários, portanto, para explicar a diversidade de mutualismos. Um processo candidato para explicar a alta riqueza de mutualismos de baixa intimidade é a convergência adaptativa favorecendo a adição de espécies não-aparentadas às redes mutualísticas (Guimarães et al. 2007, 2011). Por outro lado, em sistemas de alta intimidade, extinções e coextinções (Dátillo 2012), associadas a histórias coevolutivas estreitamente relacionadas e caracterizadas por especializações recíprocas (Thompson 2005) impediriam a adição de espécies nãoaparentadas, explicando assim suas riquezas relativamente baixas, apesar de um maior potencial de diversificação adaptativa.

\section{Reconfigurações adaptativas e a variação estrutural de redes mutualistas}

No Capítulo 3, mostramos que a seleção natural subjacente às reconfigurações adaptativas é uma mecanismo que pode explicar parcialmente a variação estrutural de redes ecológicas que descrevem a organização de assembleias mutualistas. Os graus de aninhamento e modularidade que caracterizam redes otimizadas que emergem em nossos modelos de reconfigurações adaptativas, respectivamente aumentados e diminuídos em relação a redes probabilísticas iniciais, reproduzem as propriedades estruturais empíricas apenas em mutualismos de baixa intimidade, e especialmente em redes de interações entre plantas e polinizadores e entre plantas e dispersores de sementes, mas não são capazes de reproduzir a estrutura de mutualismos de alta intimidade. Portanto, é possível afirmar que reconfigurações adaptativas não são um mecanismo geral capaz de explicar a variação estrutural em todos os tipos de redes mutualistas, mas podem ser um mecanismo relevante para alguns sistemas caracterizados por maior flexibilidade em relação a mudanças de ligações entre espécies. 
Nos modelos de reconfiguração adaptativa, embora o grau de aumento do aninhamento emergente não dependa do tamanho da rede mutualista, redes contendo mais espécies são mais frequentemente instáveis. Uma previsão decorrente desse resultado é que graus de aninhamento maiores do que o esperado ao acaso seriam pouco comuns em redes com maiores riquezas e mais comum em redes de riqueza baixa a intermediária, conforme sustentado por evidências empíricas (Joppa et al. 2010). Também mostramos que diferentes cenários de competição interespecífica não influenciam a frequência de desestabilização decorrente de reconfigurações adaptativas. Entretanto, quando espécies competem por parceiros mutualistas, os eventos de reconfiguração das redes continuam a acumular em uma dinâmica sem fim, mesmo depois que a arquitetura da rede não muda mais. Tal resultado sugere que a competição por parceiros mutualistas em contextos nos quais reconfigurações adaptativas são factíveis pode ser um mecanismo potencial explicando altos graus de reposição de interações em assembleias caracterizadas por padrões estruturais estáveis no nível de rede.

\section{Efeitos da especiação sobre a estrutura e estabilidade de redes mutualistas}

No Capítulo 4, tentamos os primeiros passos na construção de uma abordagem integrativa entre a síntese contemporânea da teoria de especiação e o antigo debate sobre diversidade e estabilidade. Utilizamos um modelo simples para permitir comparações entre os efeitos de diferentes modos de especiação sobre a estrutura e dinâmica de assembleias mutualistas. A partir de regras de reorganização de nicho definidas por parâmetros empiricamente mensuráveis (amplitude e sobreposição de uso de recursos), previmos que, surpreendentemente, um único evento de especiação pode ter efeitos de grande magnitude sobre a estrutura de uma rede ecológica. Embora, em nossos modelos, mudanças de grande magnitude no aninhamento ocorram em consequência da especiação, alterações na conectância e modularidade definidas por expansões ou retrações de nicho no curso da cladogênese parecem ser os determinantes do impacto de espécies emergentes sobre a estabilidade comunitária.

Nossos resultados sugerem que as consequências de diferentes modos de especiação sobre a estabilidade são primariamente controladas pelo efeito da cladogênese sobre a amplitude de nicho, sem que o padrão emergente de sobreposição no uso de recursos influencie qualitativamente a dinâmica ecológica. Processos adaptativos de especiação que reduzam a amplitude de nicho via deslocamento de caracteres ou outros mecanismos gerariam 
taxa cuja incorporação às comunidades locais pode ocorrer sem que haja desestabilização. Assim, eventos de especiação simpátrica, geralmente tidos como incomuns, mais frequentemente gerariam, por outro lado, espécies persistentes sob estruturas comunitárias existentes. Adicionalmente, previmos que eventos de especiação em que as espécies emergentes tornam-se generalistas em relação à ancestral devem desestabilizar as comunidades, o que seria plausível, por exemplo, por adaptações divergentes para exploração de recursos complementares (refúgios competitivos) após o contato secundário ou, ainda, sob vicariância, como resultado de adaptações locais contrastantes favorecendo o aumento do número de mutualistas.

\section{Linhas de investigação possíveis para o futuro}

Abordagens recentes que buscam integrar a ecologia e evolução adaptativa, como os estudos de modelagem apresentados nesta tese, representam apenas os primeiros passos daquilo que precisa ser uma "renascença na combinação das teorias ecológica e evolutiva" (Thompson 2009) em busca de uma compreensão mais ampla sobre a biodiversidade. Listamos a seguir possibilidades de investigação que podem, no futuro, dar seguimento às abordagens aqui utilizadas ou, ainda, explorar novos aspectos do amplo campo de investigações definido pelas relações entre seleção natural, estrutura e dinâmica de assembleias mutualistas.

\section{Diversificação adaptativa e seleção conflitante}

As múltiplas interações bióticas nas quais os organismos estão inseridos podem atuar tanto antagonisticamente como sinergicamente sobre a evolução e diversificação fenotípicas (Strauss \& Irwin 2004). Em relação a efeitos antagônicos entre forças seletivas de origem distintas, os seguintes pontos podem ser úteis para o planejamento de futuros estudos sobre diversificação adaptativa:

- os regimes disruptivos, que constituem forças diversificadoras, podem originar-se não somente da competição intraespecífica, mas de uma diversidade de interações ecológicas (Doebeli \& Dieckmann 2000);

- a seleção estabilizadora, que restringe a diversificação, pode emergir como consequência de mutualismos caracterizados por congruência de traços (Capitulo 2), resultar da ação de fatores abióticos favorecendo um traço ótimo (Yoder \& Nuismer 2010) ou ser reforçada pela seleção sexual, uma vez que na natureza os fenótipos 
extremos raros podem não ter as mesmas probabilidades de acasalamento que fenótipos intermediários comuns (Kirkpatrick \& Nuismer 2004);

- a seleção disruptiva decorrente de interações ecológicas pode ser reforçada por seleção sexual, por exemplo, ao favorecer a evolução de ornamentos que sinalizem adaptação local e reforcem a divergência fenotípica e o isolamento reprodutivo (van Doorn 2009);

- os resultados aqui apresentados baseiam-se em simulações numéricas. As inferências mecanísticas neles baseadas podem ser avaliadas por estudos analíticos que abordem a ação conjunta de forças de seleção impostas por variadas interações bióticas;

- uma caracterização ampla das consequências de múltiplas interações bióticas para a diversificação fenotípica e especiação adaptativa requer a consideração da estrutura espacial dos regimes seletivos (Thompson 2005; Haller et al. 2014). Modelos espaciais de diversificação adaptativa poderiam ter seus resultados sistematicamente comparados a modelos alternativos baseados no pressuposto de que a diversificação depende exclusivamente de processos neutros, ou seja, os organismos não interagem e não sofrem efeitos da seleção natural, mas evoluem sob efeitos combinados da reprodução sexuada, mutações e dispersão, de forma que a diversificação das espécies resultaria de efeitos da diferenciação genética estocástica e do isolamento pela distância (e.g., de Aguiar et al. 2009);

- por fim, a necessária inserção de modelos de especiação adaptativa no contexto comunitário mais amplo deve ainda considerar a estrutura de comunidades multiespecíficas, cuja arquitetura de interações influencia as dinâmicas evolutivas e coevolutivas (Guimarães et al. 2007, 2011).

\section{Redes adaptativas: processos anagenéticos e especiação}

Tanto o mecanismo de reconfigurações adaptativas estudado no terceiro capítulo como a reorganização das redes ecológicas resultante da especiação, estudada no quarto capítulo, podem ser relacionados à teoria de redes adaptativas (Gross \& Blasius 2008; Gross \& Sayama 2009). A abordagem de redes adaptativas é um caminho promissor de integração teórica entre ecologia e evolução, pois ela oferece o arcabouço necessário para a compreensão de retroalimentações eco-evolutivas ao descrever as relações recíprocas entre as dinâmicas no nível de rede (e.g., mudanças estruturais ao longo do tempo) e as dinâmicas que ocorrem 
dentro da rede (e.g., dinâmicas populacionais). Assim, modelos de redes adaptativas podem prover respostas a dois desafios centrais para o estudo de redes ecológicas: (i) a incorporação de dinâmicas no nível de populações, nos quais operam processos ecológicos e evolutivos fundamentais que relacionam-se às variações de abundância das espécies e à variabilidade de traços que mediam as interações ecológicas (Poisot et al., no prelo) e (ii) o desenvolvimento de uma teoria integrada da biodiversidade que ligue a evolução e diversificação de traços no nível de espécie, a dinâmica das interações ecológicas e o funcionamento dos ecossistemas (Loreau 2010). Especificamente em relação aos modelos apresentados nos capítulos 3 e 4, alguns aspectos que poderiam ser considerados em estudos futuros são:

- a incorporação de ligações proibidas às redes iniciais, de forma que nem todas as interações e reconfigurações sejam possíveis. Dessa forma seria possível avaliar a acurácia dos modelos na reprodução de padrões estruturais quando consideradas as restrições morfológicas, fenológicas e distribucionais que frequentemente limitam as interações na natureza e que tem potencial de contrabalancear a tendência dos modelos de reconfigurações adaptativas em superestimar o aninhamento das redes empíricas;

- a modelagem explícita da evolução dos traços fenotípicos que mediam as interações;

- a exploração de diferentes regras de reconfiguração de rede, com a utilização, por exemplo, de probabilidades diferenciadas de reconexão atribuídas a espécies com alto e baixo número de conexões (Ramos-Jiliberto et al. 2012) ou baseadas na similaridade filogenética entre as espécies envolvidas nas religações;

- a caracterização de mudanças dos papéis das espécies nas redes ao longo de sua evolução estrutural, descrevendo variações nas frequências relativas de espécies periféricas, conectoras de módulos e centrais (e.g., Valdovinos et al. 2009);

- outras formas de incorporação da competição interespecífica que modelem explicitamente efeitos de facilitação;

- a generalidade e respaldo empírico da dinâmica evolutiva sem fim descrita para o cenário no qual as espécies competem por mutualistas e que constitui um mecanismo potencial para explicar o padrão empírico de variações amplas nas interações entre as espécies associadas à baixa variação das propriedades estruturais das redes ao longo do tempo;

- nos modelos de especiação e reorganização de nichos, a incorporação de rearranjos das forças de interação que são plausíveis como consequência da adição de novas espécies; 
- nos casos em que a especiação leva a desestabilização e provável extinção de espécies, a caracterização da estrutura das redes ecológicas após as extinções e as subsequentes dinâmicas ecológicas e evolutivas.

\section{A natureza da biodiversidade e o desafio central para a modelagem eco-evolutiva}

Uma teoria geral da biodiversidade que contemple a ecologia evolutiva dos ecossistemas é uma demanda central em um mundo cada vez mais marcado por uma delicada relação entre desenvolvimento e a manutenção dos recursos naturais (Loreau 2010). Na construção dessa teoria geral, ou pelo menos de teorias mais gerais sobre a origem, manutenção e colapso da biodiversidade, não está sob disputa o lugar central da seleção natural como força estruturante primordial (Thompson 2009). Entretanto, debates polarizados sobre a contribuição relativa de processos neutros e adaptativos de diferenciação de nicho para a estrutura e dinâmica da biodiversidade são recorrentes na literatura. De uma perspectiva histórica, essa polarização tem servido como artifício dialético para chamar a atenção sobre a necessidade de considerarse o papel de dinâmicas neutras, de forma similar a outras dicotomias que surgiram em momentos históricos anteriores, tais como antagonismos entre "competição contra predação" ou "efeitos top-down contra efeitos bottom-up" como processos estruturadores de comunidades (Leibold \& McPeek 2006). Assim, interpretamos a discussão frequentemente polarizada sobre o papel relativo de processos neutros e adaptativos na origem e manutenção da biodiversidade como parte de uma iminente unificação de tradições acadêmicas distintas. A síntese entre essas abordagens complementares é inevitável e necessária para a compreensão da biodiversidade e para o desenvolvimento de estratégias de conservação. Um entendimento acurado sobre a natureza do desafio central para o desenvolvimento de teorias gerais sobre a biodiversidade talvez tenha sido capturado por Ricklefs (2012):

[...] "Neither niche theory nor neutral theory provides a satisfying narrative for ecological communities, and the defense of one or the other (sometimes both) by ecologists has at times slowed progress toward understanding biodiversity. Niche-based theory supports the core of our understanding of local species interactions and related constructs, including adaptive radiation. Neutral theory addresses an aspect of randomness in the natural world. Both have assumed central places in our effort to understand the distribution of diversity over the earth's surface. However, failing to observe nature fully, we have missed critical insights and not tested core predictions related to both neutral and niche-based theory. Ecological and evolutionary 
processes are, for the most part, well understood, thanks to decades of experimental science. However, the expression of these processes in the patterns of biological diversity we see around us depends on so many contingencies that we must continually balance our insights with direct observation of the natural world to guide our reasoning. Natural history still has primacy in these endeavors."

$\mathrm{Na}$ modelagem, a generalidade das explicações necessariamente leva à perda de especificidade. Essa relação inevitável frequentemente justifica a desconsideração da variação da história natural dos organismos em favorecimento de modelos supostamente gerais que, entretanto, podem representar apenas casos específicos como, por exemplo, muitos modelos de mutualismos que presumem apenas uma interação por indivíduo. Embora avanços tenham sido obtidos no sentido de uma maior incorporação da história natural a estudos sobre dinâmica evolutiva (Guimarães et al. 2007), boa parte da teoria ainda está expressa verbalmente (e.g., Thompson 2005). Considerando esse cenário, concluímos que o aprofundamento da compreensão sobre o papel das interações ecológicas na origem e manutenção da biodiversidade depende criticamente de dois fatores. Primeiro, é necessária a consolidação do entendimento de que fenômenos ecológicos podem ser descritos com generalidade, tal qual processos estudados por outras disciplinas, como a Física (Ginzburg \& Colyvan 2004). Segundo, o desenvolvimento teórico na interface entre Ecologia e Evolução deve ser feito à luz da História Natural, buscando a formalização de explicações hoje predominantemente verbais sobre a biodiversidade como modelos matemáticos que sejam gerais e, ainda assim, façam sentido frente à diversidade da vida.

$\mathrm{Na}$ medida em que não existe receita para a construção de modelos gerais sobre a biodiversidade, é necessário que a modelagem eco-evolutiva seja compreendida como sendo, em alguma medida, simultaneamente Ciência e Arte: uma mistura de empreendimentos cujo propósito fundamental não restringe-se a gerar predições quantitativas acuradas, mas inclui também a combinação entre simplicidade, intuição naturalística e criatividade para promover o aprofundamento de nossa compreensão sobre o funcionamento da natureza, gerando novas ideias que podem ser amplamente utilizadas, mesmo fora do contexto específico do modelo original (Otto \& Day 2007). Essa concepção sobre a modelagem constitui uma das linhas criativas fundamentais para alimentar uma "Renascença" integradora das teorias ecológica e evolutiva, conforme a metáfora usada por Thompson (2009) para caracterizar a magnitude e a beleza do desafio que temos pela frente ao buscarmos aprofundar as bases científicas do nosso esforço para compreendermos e garantirmos o futuro da diversidade biológica. 


\section{Referências}

Aguiar, M.A.M. de, Baranger, M., Baptestini, E.M., Kaufman, L. \& Bar-Yam, Y. (2009). Global patterns of speciation and diversity. Nature, 460, 384-387.

Dáttilo, W. (2012). Different tolerances of symbiotic and nonsymbiotic ant-plant networks to species extinctions. Netw. Biol., 2, 127-138.

Doebeli, M. \& Dieckmann, U. (2000). Evolutionary branching and sympatric speciation caused by different types of ecological interactions. Am. Nat., 156, S77-S101.

Ginzburg, L. \& Colyvan, M. (2004). Ecological orbits: how planets move and populations grow. Oxford University Press, Oxford.

Gross, T. \& Blasius, B. (2008). Adaptive coevolutionary networks: a review. J. R. Soc. Interface, 5, 259-271.

Gross, T. \& Sayama, H. (2009). Adaptive Networks. Heidelberg, Berlin.

Guimarães, P.R., Jr, Rico-Gray, V., Oliveira, P.S., Izzo, T.J., Reis, Dos, S.F.F. \& Thompson, J.N. (2007). Interaction intimacy affects structure and coevolutionary dynamics in mutualistic networks. Curr. Biol., 17, 1797-1803.

Guimarães, P.R., Jr, Jordano, P. \& Thompson, J.N. (2011). Evolution and coevolution in mutualistic networks. Ecol. Lett., 14, 877-885.

Haller, B.C., Mazzucco, R. \& Dieckmann, U. (2013). Evolutionary branching in complex landscapes. Am. Nat., 182, E127-E141.

Joppa, L.N., Montoya, J.M., Solé, R., Sanderson, J. \& Pimm, S.L. (2010). On nestedness in ecological networks. Evol. Ecol. Res., 12, 35-46.

Kirkpatrick, M. \& Nuismer, S.L. (2004). Sexual selection can constrain sympatric speciation. Proc. R. Soc. B, 271, 687-693.

Leibold, M.A. \& McPeek, M.A. (2006). Coexistence of the niche and neutral perspectives in community ecology. Ecology, 87, 1399-1410.

Loreau, M. (2010). Linking biodiversity and ecosystems: towards a unifying ecological theory. Philos. T. R. Soc. B, 365, 49-60.

Otto, S.P. \& Day, T. (2007). A biologist's guide to mathematical modeling in Ecology and Evolution. Princeton University Press, Princeton.

Poisot, T., Stouffer, D.B. \& Gravel, D. (2015). Beyond species: why ecological interaction networks vary through space and time. Oikos (no prelo).

Ramos-Jiliberto, R., Valdovinos, F.S., Moisset de Espanés, P. \& Flores, J.D. (2012). Topological plasticity increases robustness of mutualistic networks. J. Anim. Ecol., 81, 896904. 
Ricklefs, R.A. (2012). Naturalists, natural history, and the nature of biodiversity. Am. Nat., $179,423-435$.

Strauss, S.Y. \& Irwin, R.E. (2004). Ecological and evolutionary consequences of multispecies plant-animal interactions. Annu. Rev. Ecol. Evol. Syst., 35, 435-466.

Thompson, J.N. (2005). The geographic mosaic of coevolution. University of Chicago Press, Chicago.

Thompson, J.N. (2009). The coevolving web of life. Am. Nat., 173, 125-140.

Valdovinos, F.S., Ramos-Jiliberto, R., Flores, J.D., Espinoza, C. \& Lopez, G. (2009). Structure and dynamics of pollination networks: the role of alien plants. Oikos, 118, 11901200 .

van Doorn, G. S., Edelaar, P. \& Weissing, F.J. (2009). On the origin of species by natural and sexual selection. Science, 326, 1704-1707.

Yoder, J.B. \& Nuismer, S.L. (2010). When does coevolution promote diversification? Am. Nat., 176, 802-817. 